\title{
River Protection Project FY 2000 Multi-Year Work Plan Summary
}

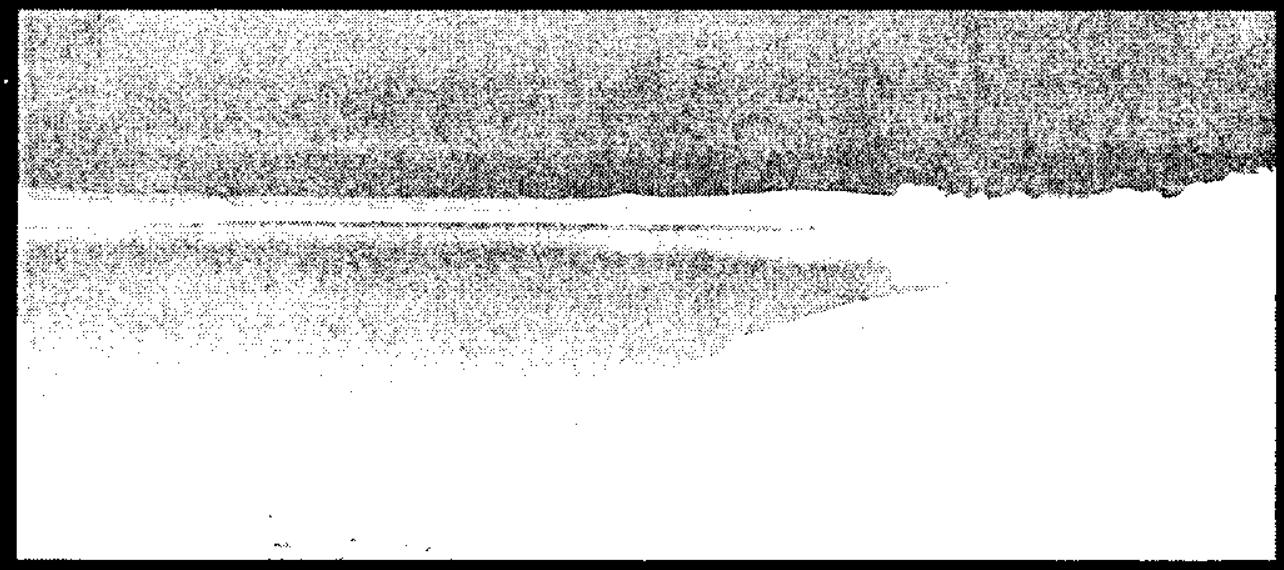

Prepared for the U.S. Department of Energy

\section{RECORD COPY}

Hanford Management and Integration Contractor for the

U.S. Department of Energy under Contract DE-AC06-96RL13200 


\section{River Protection Project FY 2000 Multi-Year Work Plan Summary}

Lockheed Martin Hanford Corporation

Date Published

August 1999

Prepared for the U.S. Department of Energy

Hanford Management and Integration Contractor for the

U.S. Department of Energy under Contract DE-ACO6-96RL13200

Approved for Public Release 


\section{RELEASE AUTHORIZATION}

Document

Number:

Document

Title:
RPP-5044, Rev. 0

River Protection Project FY 2000 Multi-Year Nork

Plan Summary

\section{This document, reviewed in accordance with DOE Order 241.1, "Scientific and Technical Information Management," and DOE G 241.1-1, "Guide to the Management of Scientific and Technical Information," does not contain classified or sensitive unclassified information and is:}

\section{APPROVED FOR PUBLIC RELEASE}

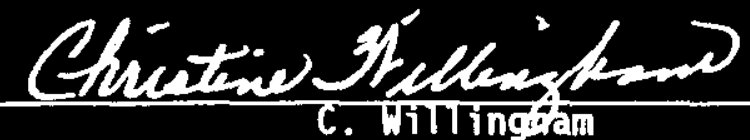 \\ Lockheed Mart in Services, Inc. \\ Document Control/Information Clearance}

$8 / 27 / 99$

Reviewed for hpilied Jechology, Bus iness Sensitive, Crassifted, Coprifited, Bxport Controlted, Patent, Personal/Private, Proprietary, Protected caho, Tredemark, Unelessified controlled wuclear Information.

LEEAL DISCLAIKER. This reoort was prepared as an aceount of wrk epensored by an agency of the United States Governimt. Neither the United States Governivent nor any asoncy thereof, not any of their eaployees, wor any of their contractore, subeentractors or thair employees, makes eny warrenty, express or iliplied, or assunies any lejal lisbility or respens ibility for the eccuracy, ccuipleteness, or any third party's use or the results of such use of eny information, apparatus, product, or process disclosed, or represents that its use wuld not infrince privotely ound riohts. Reference herein to any specific conbercial product, precess, or service by trede num, tradame, mafacturer, or otheruise, does not necessarily constitute or inply its endorsement, recelinendation, or fovoring by the United states covernivent or any asency thereof or its centractors or subeontractors. The vieus and opinions of authors expressed herein do not necessarily state or reflect those of the United states Governient or any agency thereof. This report has been reproduced from the best available copy. Printed in the United States of Amarica. 


\section{TABLE OF CONTENTS}

1.0 River Protection Project Overview ............................................................................ 1-1

1.1 River Protection Project Formation .................................................................... 1-1

1.2 RPP Work Breakdown Structure/Organization .................................................. 1-1

1.3 Significant Changes From Previous Years ......................................................... 1-3

1.4 Major Assumptions ............................................................................................ 1-3

1.5 Significant Work Scope Changes From Last Year ................................................ 1-4

1.6 Significant Issues ........................................................................................... 1-5

1.7 Technical Basis Review Process........................................................................ 1-5

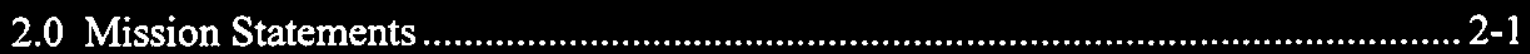

2.1 EM Mission Statement............................................................................... 2-1

2.2 Hanford Mission Statement ............................................................................. 2-1

2.3 Office of River Protection Mission Statement................................................... 2-1

3.0 Programmatic Background ................................................................................. 3-1

3.1 Policy and Planning Evaluation ........................................................................ 3-1

3.2 Waste Tank Safety Issues ........................................................................... 3-2

3.3 Environmental Impact Statement................................................................... 3-3

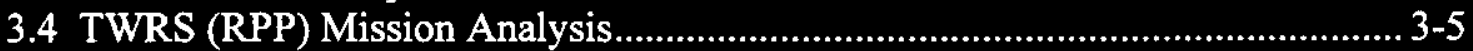

4.0 Risk Sharing Strategy ......................................................................................... 4-1

5.0 River Protection Project Master Schedule ................................................................. 5-1

6.0 Project Master Baseline Schedule (FY 2000 to 2006) ................................................ 6-1

7.0 River Protection Project Cost Profiles ..................................................................... 7-1

7.1 Budget Authority (FY 2000 to 20006)......................................................... 7-2

7.2 Life-Cycle Costs by Fiscal Year ...................................................................... 7-3

8.0 Major Risks and Mitigation Actions................................................................... 8-1

9.0 Project Baseline Summary Overviews.......................................................................... 9-1

9.1 Tank Waste Characterization (TW01) ........................................................... 9-1

9.2 Tank Safety Issue Resolution (TW02)....................................................... 9-11

9.3 Tank Farm Operations (TW03) ............................................................... 9-17

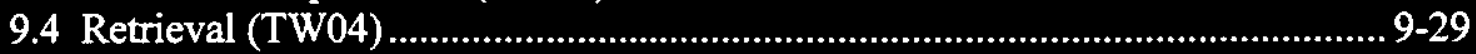

9.5 Process Waste Support (TW05) ........................................................................ 9-49

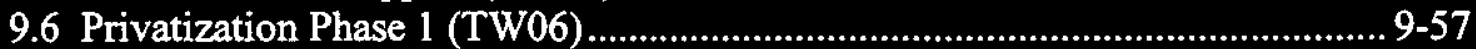

9.7 Privatization Phase 2 (TW07) ....................................................................... 9-65

9.8 Privatization Infrastructure (TW08) ............................................................... 9-71

9.9 Immobilized Tank Waste Storage and Disposal (TW09) .................................... 9-81

9.10 RPP Management Support (TW10) ................................................................. 9-93

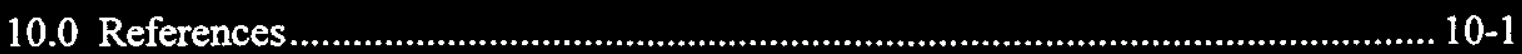


RPP-5044

2

\section{TABLE OF CONTENTS (cont.)}

\section{APPENDIXES}

Appendix A Typical Fiscal Year Calendar

Appendix B Project Priority List

Appendix C Instructions on Accessing Electronic MYWP

Appendix D Electronic Access of TBR Data 
Figures

1 Fiscal Year 2000 Baseline Planning Matrix $1-2$ Tables

1 Project Priority List Compliance Funding Level ....................................................... 1-4 
RPP-5044

This page intentionally left blank. 


\section{RIVER PROTECTION PROJECT FY 2000 MULTI-YEAR WORK PLAN SUMMARY}

\subsection{RIVER PROTECTION PROJECT OVERVIEW}

\subsection{River Protection Project Formation}

The River Protection Project (RPP), formerly the Tank Waste Remediation System (TWRS), is a major part of the U.S. Department of Energy's (DOE) Office of River Protection (ORP). The ORP was established as directed by Congress in Section 3139 of the Strom Thurmond National Defense Authorization Act for Fiscal Year (FY) 1999. The ORP was established to elevate the reporting and accountability for the RPP to the DOE-Headquarters level. This was done to gain Congressional visibility and obtain support for a major $\$ 10$ billion high-level liquid waste vitrification effort.

\subsection{RPP Work Breakdown Structure/Organization}

The RPP is organized in a structure consisting of 10 Project Baseline Summaries (PBS). The following PBSs make up the RPP:

$\begin{array}{ll}\text { TW01 } & \text { Tank Waste Characterization } \\ \text { TW02 } & \text { Tank Safety Issue Resolution } \\ \text { TW03 } & \text { Tank Farm Operations } \\ \text { TW04 } & \text { Retrieval } \\ \text { TW05 } & \text { Process Waste Support } \\ \text { TW06 } & \text { Privatization Phase 1 } \\ \text { TW07 } & \text { Privatization Phase 2 } \\ \text { TW08 } & \text { Privatization Infrastructure } \\ \text { TW09 } & \text { Immobilized Tank Waste Storage and Disposal } \\ \text { TW10 } & \text { Management Support. }\end{array}$

The planning for RPP is consistent with the overall-planning schedule for the entire Hanford Site. Appendix A shows the overall fiscal year planning process flow. As part of the multi-year work plan (MYWP) process, work scope is prioritized and agreed to at all levels of management. This results in developing the Project Priority List (PPL) that, along with customer guidance, forms the basis for work scope determination for the revised baseline. The PPL for the fiscal year (FY) 2000 MYWP is included as Appendix B. Individual plans are then created for each PBS for incorporating scope, schedule, and 
RPP-5044

$1-2$

cost. Baseline planning is conducted in line with Lockheed Martin Hanford Corporation (LMHC) Management Directive LMH-MD-018, the specifics of which are depicted in the Baseline Planning Matrix (Figure 1).

Figure 1. Fiscal Year 2000 Baseline Planning Matrix. ${ }^{1}$

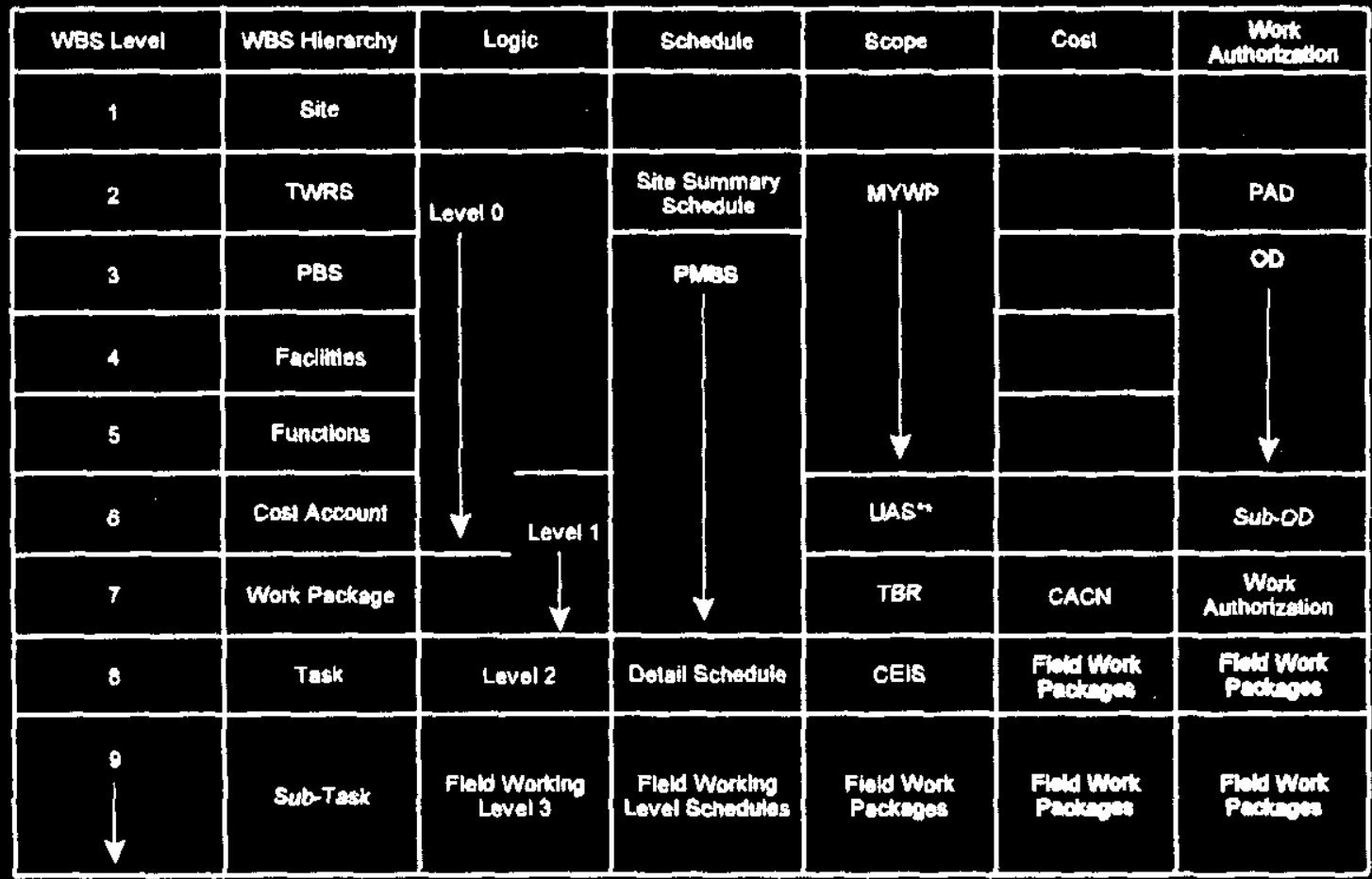

thine hem Projocts and Sak Well Pumping can plan LogidSchodula/scepa/Cest to Lovel 11 of Was to allow visibility of discrete tesks. See athernste methx.

mpoposed implementetion aner the FY 2001 PSS ewbnttat.

The U.S. Department of Energy, Richland Operations Office (RL), LMHC, and the ORP have begun discussions leading to withdrawing LMHC's subcontract from the Project Hanford Management Contract (PHMC) and assigning it to the DOE, managed by the ORP. This will create a direct contractual relationship between LMHC and DOE that will optimize RPP integration. The transition process is expected to be complete by October 1, 1999.

${ }^{1}$ TWRS, used in Figure 1, is now called the River Protection Project (RPP). 


\subsection{Significant Changes From Previous Years}

The following significant changes have been made in the MYWP from previous years:

The major change in the MYWP from previous years is in the delivery format. For FY 2000 the MYWP need not be published as a hard-copy document. Instead, the MYWP will be available via desktop application for all Hanford Local Area Network (HLAN) (the Hanford Site computer network) users. Significant emphasis is being placed on source-system feeds of data housed in appropriate systems. See Appendix $\mathbf{C}$ for instructions on accessing the electronic MYWP.

- The Technical Basis Review (TBR), which forms the basis for the detail planning of the baseline, is available in a central storage location and maintained under strict configuration management. To facilitate their review, MYWP reviewers will be given access to this system. See Appendix D for access instructions.

Each mission area (RPP, Spent Nuclear Fuels, etc.) will prepare a Site Summary Schedule (SSS) which will form the basis of the SSS for the entire Hanford Site. The SSS is a high-level graphic depiction of the life cycle of the Hanford Site that displays major projects' activities and their key interfaces. It includes selected enforceable agreement milestones, end-point targets, Defense Nuclear Facility Safety Board commitments and Hanford Site Critical Closure Path milestones. Preparation of the SSS will contribute to satisfying the requirement that the MYWPs be aligned with each other and with the Integrated Site Baseline (ISB). The technical, schedule, and cost baselines that make up the ISB are the standards against which progress is measured.

\subsection{Major Assumptions}

The following major assumptions were used in preparing the FY 2000 MYWP.

- The FY 2000 Budget Authority (B/A) baseline and cost estimate baseline must be built to correlate with the President's Budget Submittal to Congress, which allocates $\$ 335$ million to the RPP.

For FY 2001 through 2006, the RPP shall assume funding consistent with the April 15, 1999, Project Priority List Compliance Funding Level, shown in Table 1. 
Table 1. Project Priority List Compliance Funding Level (April 15, 1999)

\begin{tabular}{|l|l|}
\hline \multicolumn{1}{|c|}{ Fiscal Year } & \multicolumn{1}{|c|}{ Funding (\$) (K) } \\
\hline 2001 & 446,129 \\
\hline 2002 & $436,998^{*}$ \\
\hline 2003 & $434,719^{*}$ \\
\hline 2004 & $447,123^{*}$ \\
\hline 2005 & $442,846^{*}$ \\
\hline 2006 & $339,755^{*}$ \\
\hline
\end{tabular}

*As a result of incremental scope associated with the extended order quantities, ILAW/HLW failed melters and sample transport design and construction, modifying/updating tank farm piping systems and infrastructure, the funding requirements have exceeded the target levels as listed above.

For the years beyond FY 2006, the RPP shall assume the compliance case plus any additional necessary requirements.

- RPP planning will incorporate and integrate all contractor requirements.

- Waste retrieval activities will be initiated consistent with the following start-up dates:

Start of pretreatment by April 2006

Start of high-level waste vitrification by February 2007

Start of low-activity waste vitrification by January 2008.

\subsection{Significant Work Scope Changes From Last Year}

Significant changes in work scope for FY 2000 are as follows:

- Consistent with the Level 0 Logic, operation and maintenance of the tank farms and program management support efforts have been extended from FY 2024 to FY 2034.

- Operation of the 242-A Evaporator has been added to the baseline.

- Equipment and systems to retrieve nine additional tanks for extended-order quantity feed requirements has been added (Projects W521, 522, and 523).

- Additional trade studies that will provide data in support of current tank retrieval strategy are included. 
- Work scope to modify or update tank farm piping systems and infrastructure (Project W-314, Facility Walkdowns, Tank Farm Spare Equipment, etc.) has been added.

- New scope for design and construction of immobilized low-activity waste and immobilized high-level waste failed melters and sample transport has been added.

Additional characterization sampling for retrieval has been added.

Work scope to effect the acceleration of Phase 2 waste retrieval from single-shell tanks is included.

\subsection{Significant Issues}

The following significant issues are associated with the FY 2000 MYWP.

- The target funding levels for FY 2002 - FY 2006 were not achievable due to increased work scope that was added to the baseline. The FY 2001 funding requirements meet the target funding guidance of $\$ 446 \mathrm{M}$, but exceed the Congressional target funding of $\$ 382 \mathrm{M}$. Constraining the schedule to $\$ 382 \mathrm{M}$ would impact the scheduled Privatization start-up dates.

- This MYWP defers the development and testing of alternative single-shell tank waste retrieval and heel removal techniques (Hanford Tank Initiative).

This MYWP defers development of the balance of mission single-shell tank waste retrieval and closure of the Tank Farm Facility and defers the development of a technical basis from which to negotiate changes to the 2018 milestone date specified in the Hanford Federal Facility Agreement and Consent Order (TriParty Agreement) (Ecology et al. 1996) to remove waste from single-shell tanks.

- This MYWP extends the Final Safety Analysis Report (FSAR) Phase 2 Implementation across FYs 2000 and 2001 instead of scheduling completion for FY 2000. FSAR Phase 2 implementation will continue to operate under Basis of Interim Operations until implementation complete.

This MYWP does not include increased contract support (Waste Integration Team) needed to validate the August 2000 privatization go-ahead with BNFL Inc.

\subsection{The Technical Basis Review Process}

The TBR process is an integral part of the integrated planning process. After the physical configuration and operational requirements have been defined in the technical baseline, the work breakdown structure (WBS), work definition, and Level 0 and Level 1 logics are developed. The TBR process provides for development of the lower levels of the 
WBS and the lower levels of the schedule logic. The process documents the description, requirements, and enabling assumptions for the Level 2 and lower technical work scope using the TBR narrative format. The detailed schedule is resource loaded and documented using the cost estimating input sheet (CEIS) format. Data derived from the TBR process feed the Risk Management process. The final product of the TBR process is a resource-loaded schedule that, when priced by the scheduling software, produces the scope, schedule, and supporting cost estimates that constitute the project life-cycle baseline. This schedule serves as the basis for developing the MYWP and reporting execution-year performance.

The TBR is an effective tool for developing proposals, estimates, and budgets; and preserving the supporting data for such deliverable documents. The TBR is based on cost estimates that incorporate the following:

- Use of standardized estimating techniques using the activity-based cost (ABC) estimating method in accordance with applicable requirements

- Reductions of time and resources needed to validate or revise estimates

- Use of meaningful cost data to increase the accuracy of cost estimates

- Identification of resource requirements for the base or minimum safe operating condition

- Use of summarized program management information to support the budget and change order process

- Reduction of the number of tracking elements and development of the appropriate performance measures for the financial and program management systems. 


\subsection{MISSION STATEMENTS}

\subsection{EM Mission Statement}

Hanford's environmental management, or cleanup, mission is to protect the health and safety of the public, workers, and the environment; control hazardous materials; and utilize the assets (people, infrastructure, site) for other missions.

\subsection{Hanford Mission Statement}

Hanford's missions are to safely clean up and manage the site's legacy wastes, and to develop and deploy science and technology.

\subsection{Office of River Protection Mission Statement}

The Office of River Protection's mission is to store, treat, immobilize and dispose of the highly radioactive Hanford Site tank waste (including current and future tank waste and the cesium and strontium capsules) in an environmentally sound, safe, and cost-effective manner. 
RPP-5044

2-2

This page intentionally left blank. 


\subsection{PROGRAMMATIC BACKGROUND}

The Hanford Site was established in 1943 as part of the Manhattan Project. At that time, the Site's mission was to produce plutonium for use in nuclear weapons. Over the years, nine nuclear reactors and two large areas containing several nuclear chemical processing complexes were built. The chemical processing operations produced large quantities of highly radioactive waste. These waste materials were stored in many large underground tanks. Today, more than $204,412 \mathrm{~kL}(54,000,000 \mathrm{gal})$ of high-level radioactive waste are stored in 177 underground tanks.

\subsection{POLICY AND PLANNING EVALUATION}

As the Hanford Site evolved and additional waste storage space was needed, additional waste tanks were built. In the 1950's and 1960's, DOE recognized that more needed to be done to secure the waste, particularly because some of the tanks were confirmed to be leaking. Little else actually was done about waste disposal because of limited budgets.

In the 1970's, the pace of planning and development for safe waste storage and disposal increased. Several formal studies of waste disposal altematives were conducted. Research, development, and demonstration of waste treatment processes, including vitrification, were completed. Much of this work was done at the Hanford Site.

In the early 1980 's, Congress requested that DOE plan for the disposal of the high-level waste that had accumulated from the DOE's nuclear activities. In response to this request, in 1983, DOE issued the Defense Waste Management Plan (DOE 1983). In it, DOE proposed the strategy of retrieving the waste from storage tanks and treating it to make it suitable for disposal.

Because waste retrieval and immobilization facilities costing billions of dollars would be needed, and because similar facilities had not been built before, DOE selected a sequential approach to facility design and construction. Facilities to treat the waste at DOE's Savannah River Site in South Carolina would be constructed first. After processing was successfully demonstrated, facilities would be built at the DOE's Hanford Site in Washington State, followed by facilities at DOE's site in Idaho. Waste immobilization facilities began operating at the Savannah River Site in 1996. Therefore, proceeding with waste retrieval and immobilization facilities at the Hanford Site is the next logical step in this planning progression.

In 1987, the Hanford Defense Waste Environmental Impact Statement (DOE 1987) was issued, which laid out a strategy for addressing the Hanford Site tank waste. Waste from the double-shell tanks would be retrieved. The highly radioactive fraction would be immobilized in glass (vitrified), and the low-activity waste would be solidified in cement (grout) for disposal on the Hanford Site. Further studies would be done on the single- 
shell tanks to determine appropriate actions. This strategy was the basis for the Tri-Party Agreement (Ecology et al. 1996). The original version of the Tri-Party Agreement was signed by the Washington State Department of Ecology (Ecology), the U.S. Environmental Protection Agency, and DOE in 1989 (Ecology et al. 1989).

After the Environmental Impact Statement was issued, a TWRS mission analysis was performed to provide the basis for a technical approach responsive to the disposal option selected in the Record of Decision. This technical approach includes a summary description of the problem; the system boundaries, the environment and its interfaces, mission goals, top-level mission-driven requirements; and technical and programmanagement strategies for project success. The mission analysis also fostered development of a systematic approach to programmatic decision-making wherein consideration of project assumptions, risks, benefits, and life-cycle costs are balanced with established stakeholder values.

\subsection{WASTE TANK SAFETY ISSUES}

In early 1990, issues regarding the waste in the tanks were identified that appeared to pose unacceptable risks if waste continued in storage without corrective actions. Technical and financial resources were directed toward resolving these issues. The DOE considered the requirements of the Resource Conservation and Recovery Act of 1976 and the Nuclear Waste Policy Act of 1982 and decided to include retrieval and treatment of single-shell tank waste in the planning for the waste disposal program. This fourfold increase in waste volume to be treated, along with additional concerns about using an old facility (B Plant) for waste pretreatment and concerns about using the proposed grout form for low-activity waste disposal, caused a reevaluation of the strategy.

In December 1991, the Secretary of Energy directed that TWRS be established to plan and implement the disposal of all Hanford Site tank waste. A systems approach was used to evaluate various alternatives. These studies were used to renegotiate the Tri-Party Agreement. A strategy was developed and negotiated and the revised Tri-Party Agreement was signed in January 1994 (Ecology et al. 1994). The strategy envisioned the following:

- Retrieval of all waste from single-shell and double-shell tanks Separation of the waste into high-level activity and low-activity fractions

- Immobilization of the low-activity fraction in glass or other suitable form that would reduce volume and meet long-term disposal requirements

- Vitrification of the high-level waste for disposal in a federal repository. 
The revised agreement also established an enforceable milestone schedule with established objectives. The milestone schedule is used to assess progress toward completion of these actions.

In 1994, national concern about balancing the federal budget became a more significant issue. The DOE believed that a new approach was needed for funding and managing the construction and operation of the multi-billion dollar facilities needed for waste treatment. After considering experience and input from industry, the DOE decided on a "privatization" approach to accomplish tank waste treatment and immobilization at the Hanford Site.

As it is being used for the ORP, privatization is a fixed-price contracting method for providing waste treatment services. The DOE will award competitively bid contracts under which the contractor will design, build, and operate immobilization facilities.

The privatization project is divided into two phases, primarily to reduce the scale-up risk and successfully demonstrate that all parties can support the activities before making a huge capital investment. A plant with the capacity to process all the waste in a reasonable time will be several times larger than anything built so far, so a demonstration phase is appropriate. This reduces the private contractors' technical risk and proves their ability to successfully provide process waste containing the hazardous material. Following Phase 1B, more capacity can be added as required.

\subsection{ENVIRONMENTAL IMPACT STATEMENT}

As part of the National Environmental Policy Act of 1969 (NEPA) process, DOE must submit it's strategy and decisions for public review. An environmental impact statement (EIS) was prepared that describes the magnitude of the problem, the possible implications of continued no actions, and the alternatives that have been considered to resolve the problem (DOE EIS-0189 1996).

\subsubsection{Alternatives Considered in the Environmental Impact Statement}

Many potential alternatives and combinations of alternatives exist for treating and disposing of the tank waste. One of the challenges facing DOE and Ecology is to develop a range of reasonable alternatives for detailed analysis and presentation in the EIS. The alternatives presented in the EIS were chosen as representative of the many possible variations of the alternatives. The EIS contains an analysis of the full range of reasonable alternatives for managing and disposing of the tank waste. The continued safe management of the tank farms is included in all the alternatives. The tank waste alternatives can be grouped into the following four major categories, determined by the extent of waste retrieval. 
- Continued management alternatives. (Waste would not be retrieved.) Two continued management alternatives were analyzed. One did not include replacing double-shell tanks; the other considered replacing double-shell tanks and upgrading tank farm waste transfer systems to provide long-term management of the double-shell tank liquids.

- Minimal retrieval alternatives. Only liquid waste would be removed from the double-shell tanks and concentrated in an evaporator. The concentrated waste from the evaporator would be returned to the tanks. The solid waste would be disposed of in place in the tanks; this process is called "in situ disposal." Two in situ alternatives were analyzed. One did not include treating the waste; the other included in-tank waste treatment.

- Partial retrieval alternatives. The tank waste resulting in the fewest potential environmental impacts would be disposed of in situ. The liquid waste and the portion of solid waste that would have the greatest potential long-term impact on the groundwater would be retrieved from the tanks. The retrieved waste would be immobilized and disposed of outside the tanks; "ex situ disposal." The retrieved portion of the waste would be separated by physical and chemical processing into low-activity and high-level waste. The low-activity waste would be immobilized and disposed of on Site in near-surface concrete vaults and covered with a thick earthen barrier. The high-level waste would be immobilized and stored on Site for eventual shipment to and disposal at a potential geologic repository. Two partial retrieval alternatives were analyzed. One would result in a reduced longterm risk to human health of approximately 90 percent; the other would reduce the risk by 85 percent. These alternatives provide less long-term protection of human health, but would cost less to implement.

- Extensive retrieval altematives. All the solid and liquid waste practicable (assumed for purposes of analysis to be 99 percent) would be retrieved and separated by physical and chemical processing into low-activity and high-level waste. The low-activity waste would be immobilized and disposed of on Site in near-surface vaults and covered with a thick earthen barrier. The high-level waste would be immobilized and stored on Site for eventual shipment to and disposal at a geologic repository. Three extensive retrieval alternatives were analyzed, each with a different level of waste separation. A fourth alternative was analyzed to present the potential effect of DOE choosing to implement an extensive retrieval alternative in phases rather than immediately implementing a full-scale program. This phased approach was analyzed because of the numerous uncertainties associated with the extensive retrieval alternatives. 


\subsubsection{Alternative Selected}

DOE selected the alternative of using a phased approach to extensive retrieval. The alternative will be implemented by hiring a privatization contractor to balance the risk inherent in making sizeable investments in unproven technology. The rational for this choice is that investment in facilities should proceed on a schedule commensurate with the development of the scientific knowledge and understanding.

\subsection{The TWRS (RPP) MISSION ANALYSIS}

The TWRS Mission Analysis ( Acree 1996) was issued to assist in establishing systematic engineering and project-management approaches. It provides a conceptual framework for implementing the TWRS Justification of Mission Need (DOE 1993) and satisfying the Environmental Impact Statement.

The Mission Analysis states that the purpose of the 'TWRS Program' is to resolve tank safety issues, integrate the waste-disposal and waste-management missions, assess bases for tank-waste management and disposal, determine and develop technology needs, and ensure the availability of appropriate resources for establishing a dedicated organization to meet the technical challenges. The problem generally is described as remediation of existing waste to mitigate risks posed to the public, workers, and the environment.

The system boundary and environment descriptions include existing and future tank waste, facilities, and anticipated closure expectations. Interfaces include physical and programmatic descriptions of waste and material receipts from both onsite and offsite sources, as well as those internal and external interfaces identifying information about costs, schedules, processing status, reporting, control and associated regulations, guidance, and authorizations.

The mission-level requirements are represented as high-level quantification of the stakeholder values and mission objectives. These requirements are accomplished through implementing the 'Program Strategy' (consisting of two additional sub-strategies-the Technical Strategy and the Program Management Strategy), and an 'Acquisition Strategy'. The Technical Strategy addresses the concerns of tank-farm operations and safety issues, waste-immobilization and storage requirements, and dispositioning of capsules and transuranic waste. The Program Management Strategy describes the need to integrate the sundry project activities, operations, and technology development, using a systems engineering approach. The Acquisition Strategy discusses the combination approach using privately owned and government-owned contractor-operated resources in a two-phased acquisition strategy. 
RPP-5044

3-6

This page intentionally left blank. 


\subsection{RISK SHARING STRATEGY}

DOE's approach for RPP privatization, both technically and contractually, has evolved considerably to accommodate information gained during and after the first 2 years of the project. These modifications in approach have been coordinated with DOE's Contract Reform and Privatization Project Office, which is using the experience on RPP to refine its overall approach to privatization of cleanup projects.

In designing and implementing the path forward for RPP, DOE is establishing a contract structure that provides strong incentives to achieve project schedule, cost, and performance goals while minimizing total project cost to the government. Thus, DOE is seeking to structure an optimal contracting approach for Privatization Phase 1 that will accomplish the following:

- Allocate risks to the party best able and motivated to manage them

- Obtain the best mix of private and public financing

- Maintain appropriate decision points to adjust project direction in response to new information and bring competitive pressure to bear on project costs and approaches.

Together, these principles have guided DOE's negotiation for RPP privatization services and will continue to guide refinements as that strategy is implemented.

Privatization contracts differ significantly from traditional cost-reimbursement contracts in their allocation of risks between the government and the contractor. Under privatization, the contractor assumes a far greater share of the risks, particularly those under the contractor's control, such as technology performance and operating efficiency. Under the RPP contract, DOE has sought to allocate specific risks to the party most able to manage the risk and complete the work. DOE has evaluated a broad spectrum of risks that are potentially relevant to risk allocation decisions in privatization contracts. Accordingly, ORP has contracted with LMHC to perform tank farm operations and retrieval and disposal activities. It has contracted with BNFL Inc. to perform waste treatment and vitrification services. 
RPP-5044

4-2

This page intentionally left blank. 


\subsection{RIVER PROTECTION PROJECT MASTER SCHEDULE}




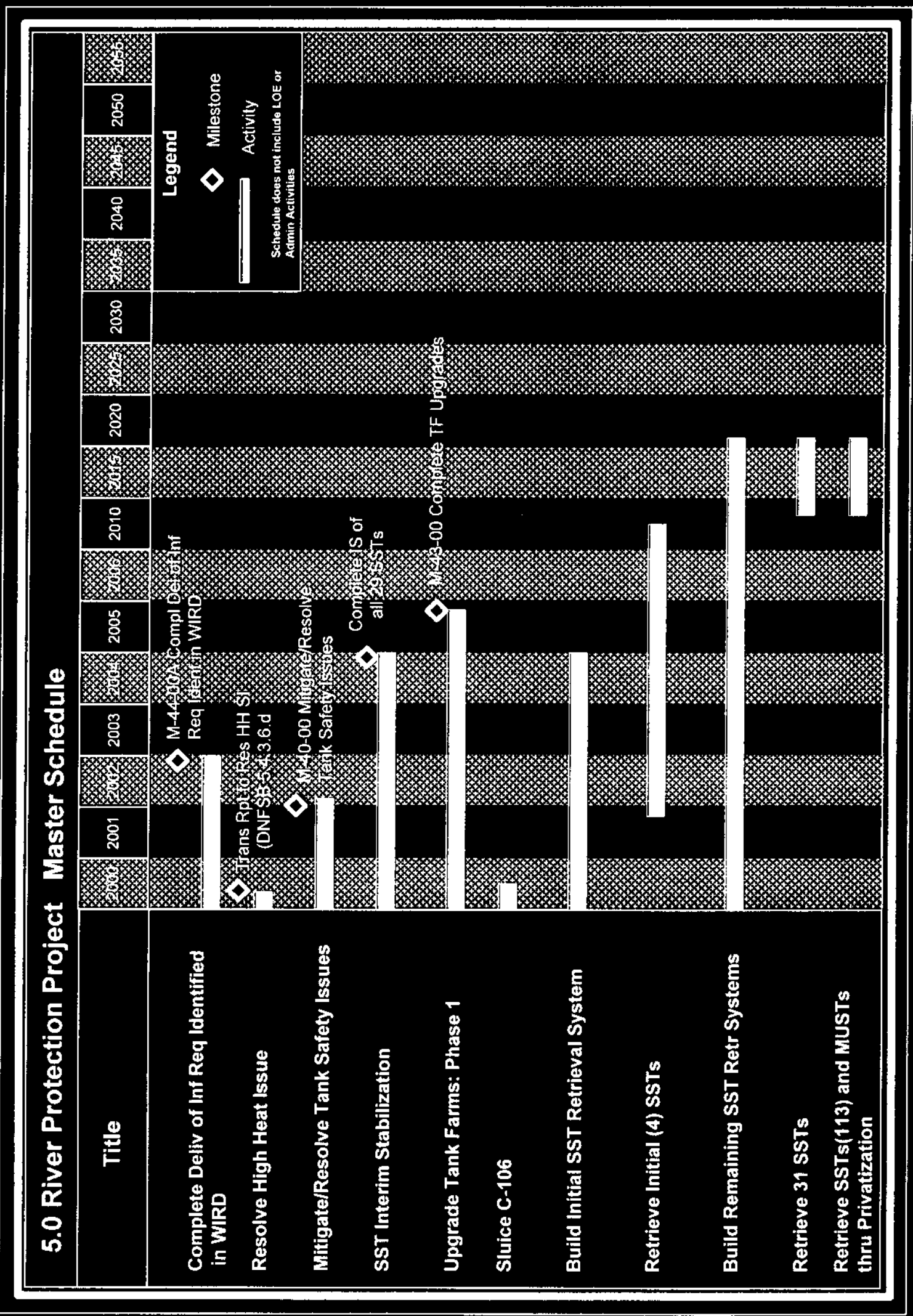




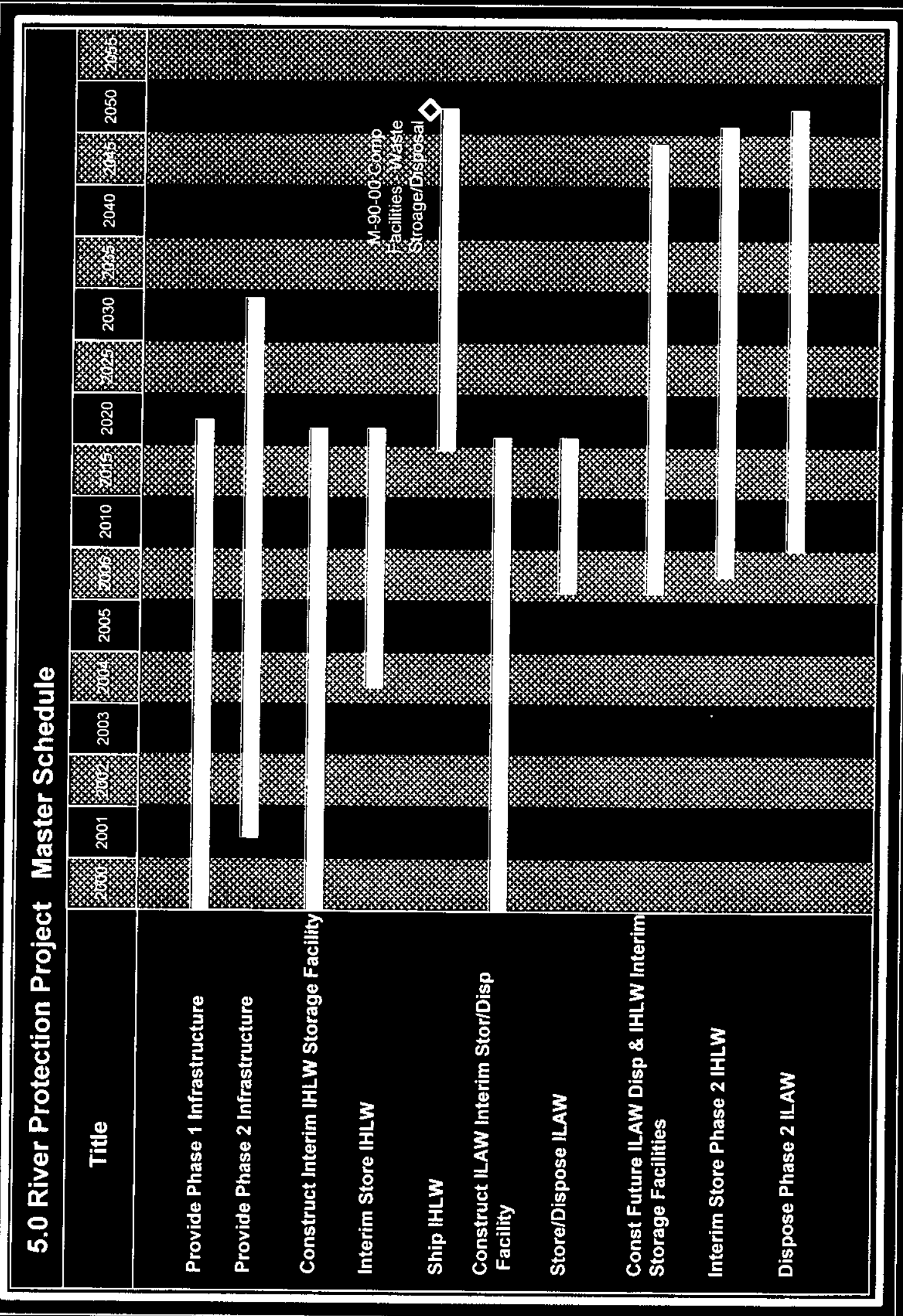




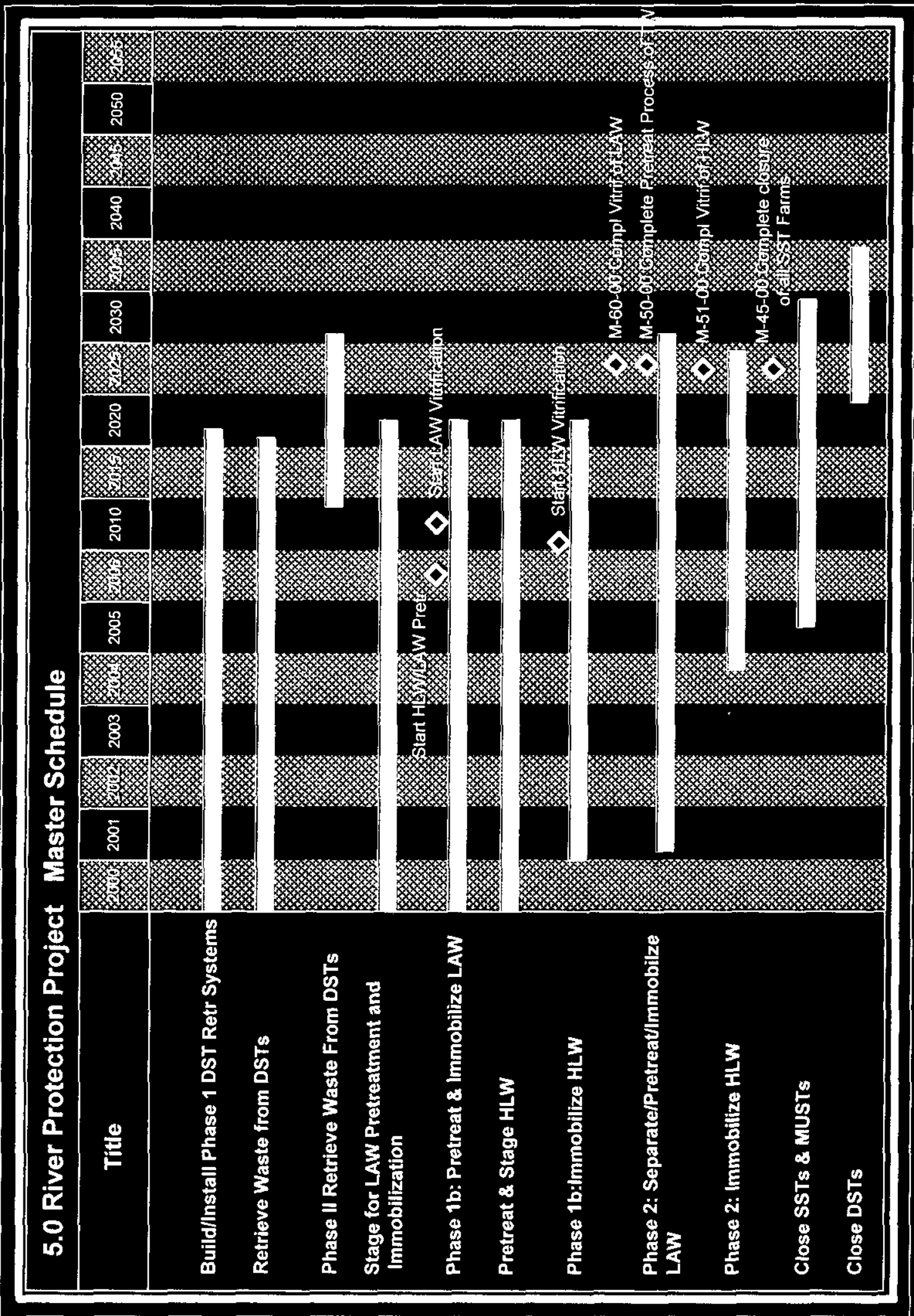


RPP-5044

6-1

6.0 PROJECT MASTER BASELINE SCHEDULE (FY 2000 to 2006) 


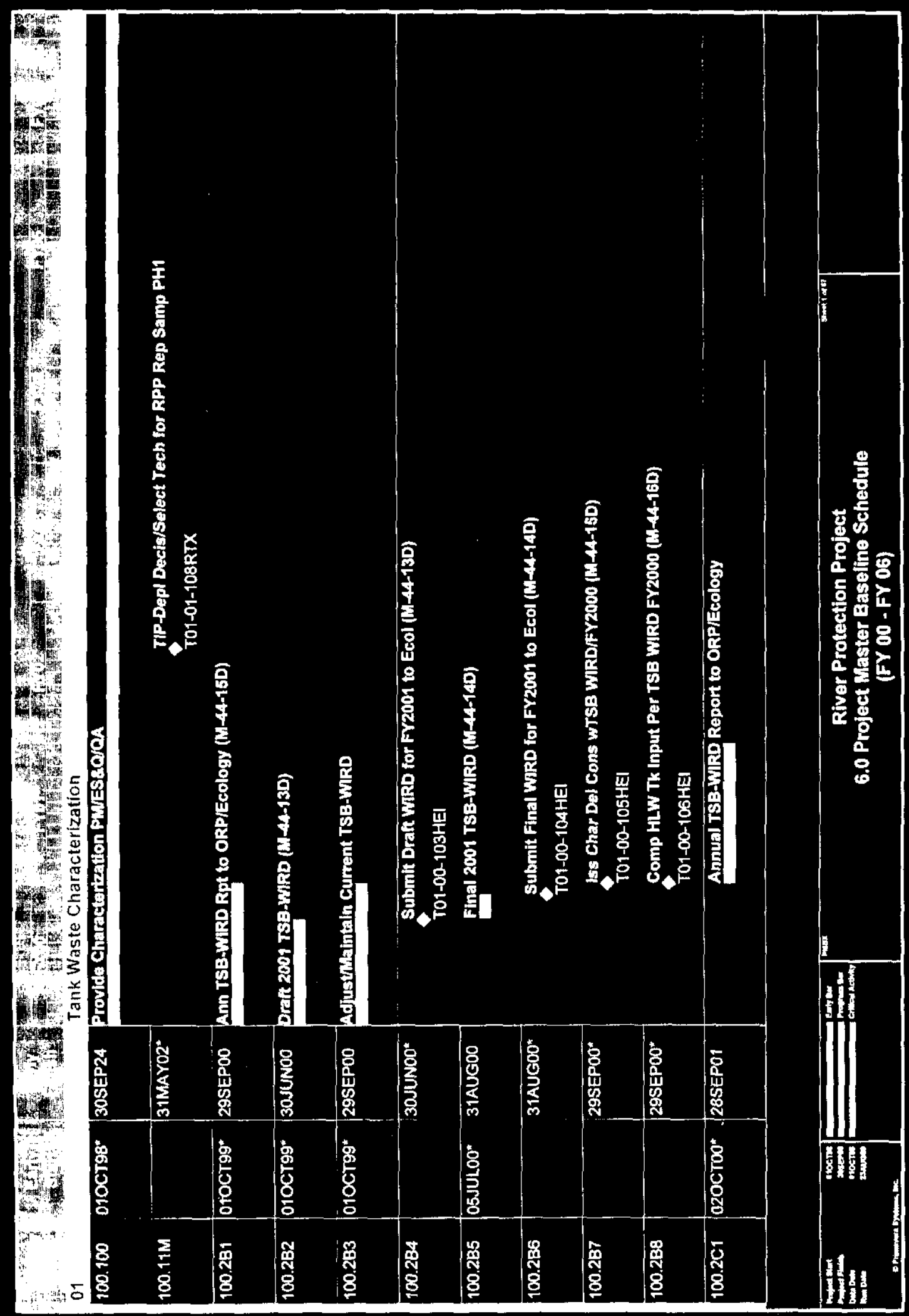




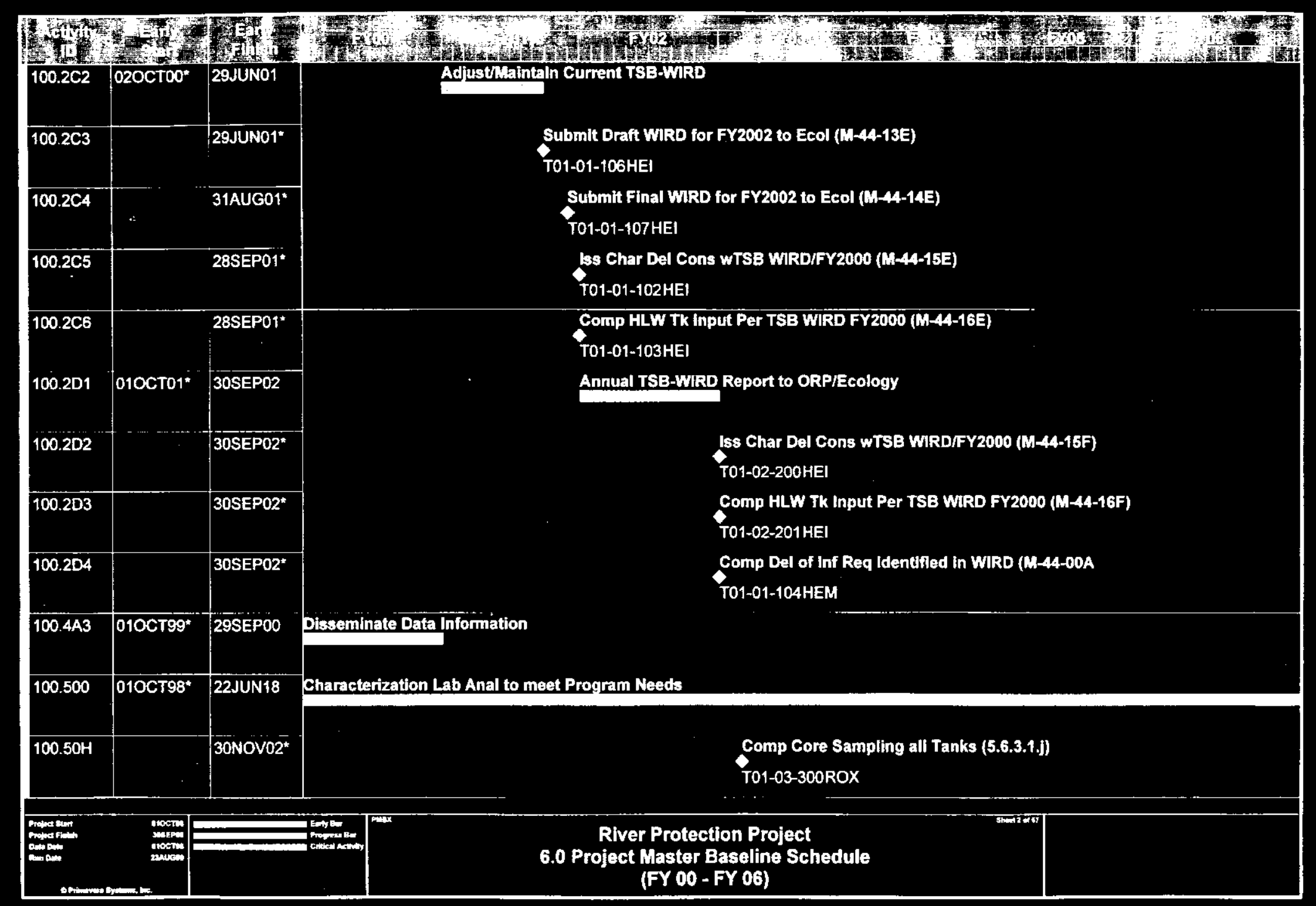


RPP-5044

6-4

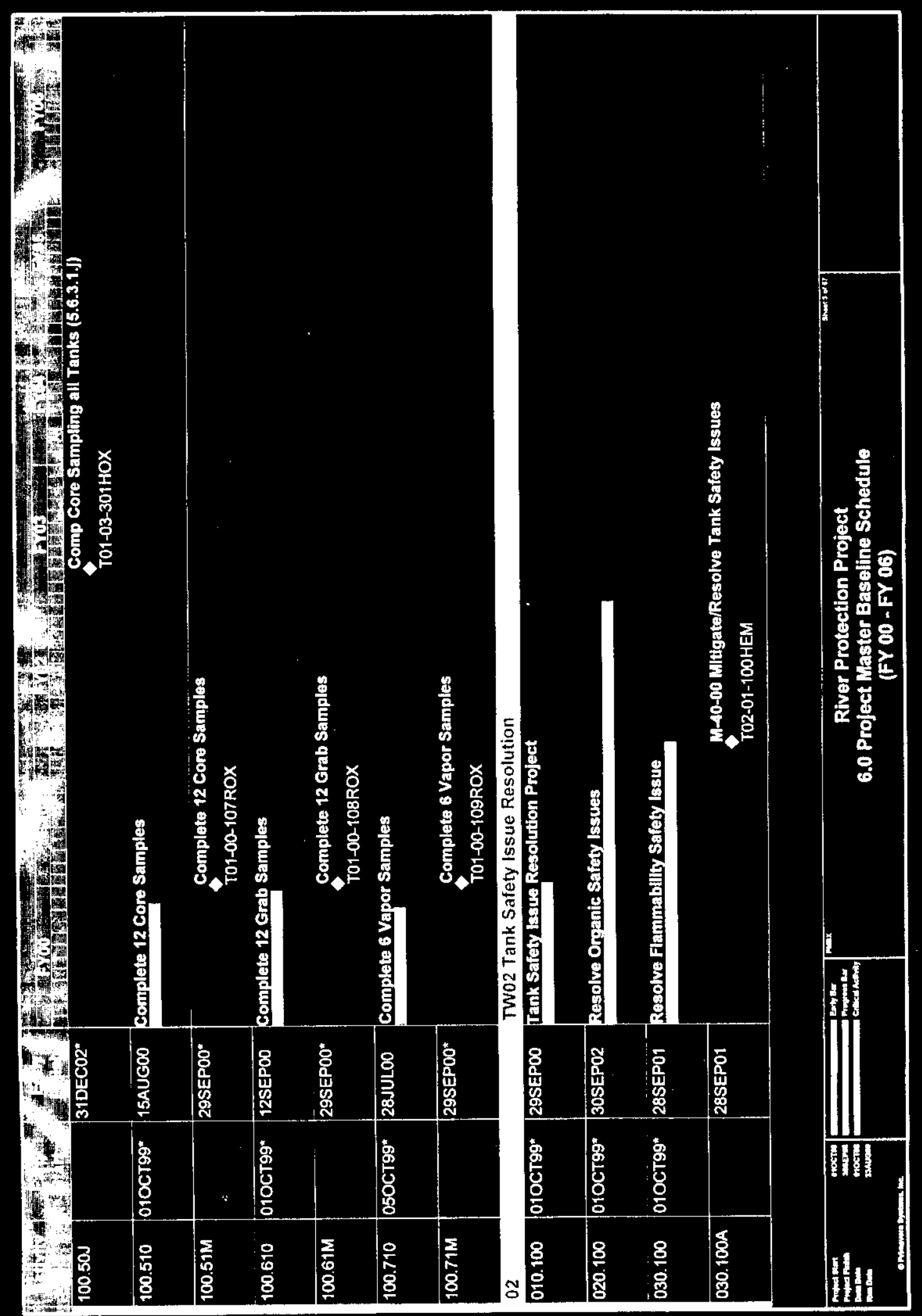




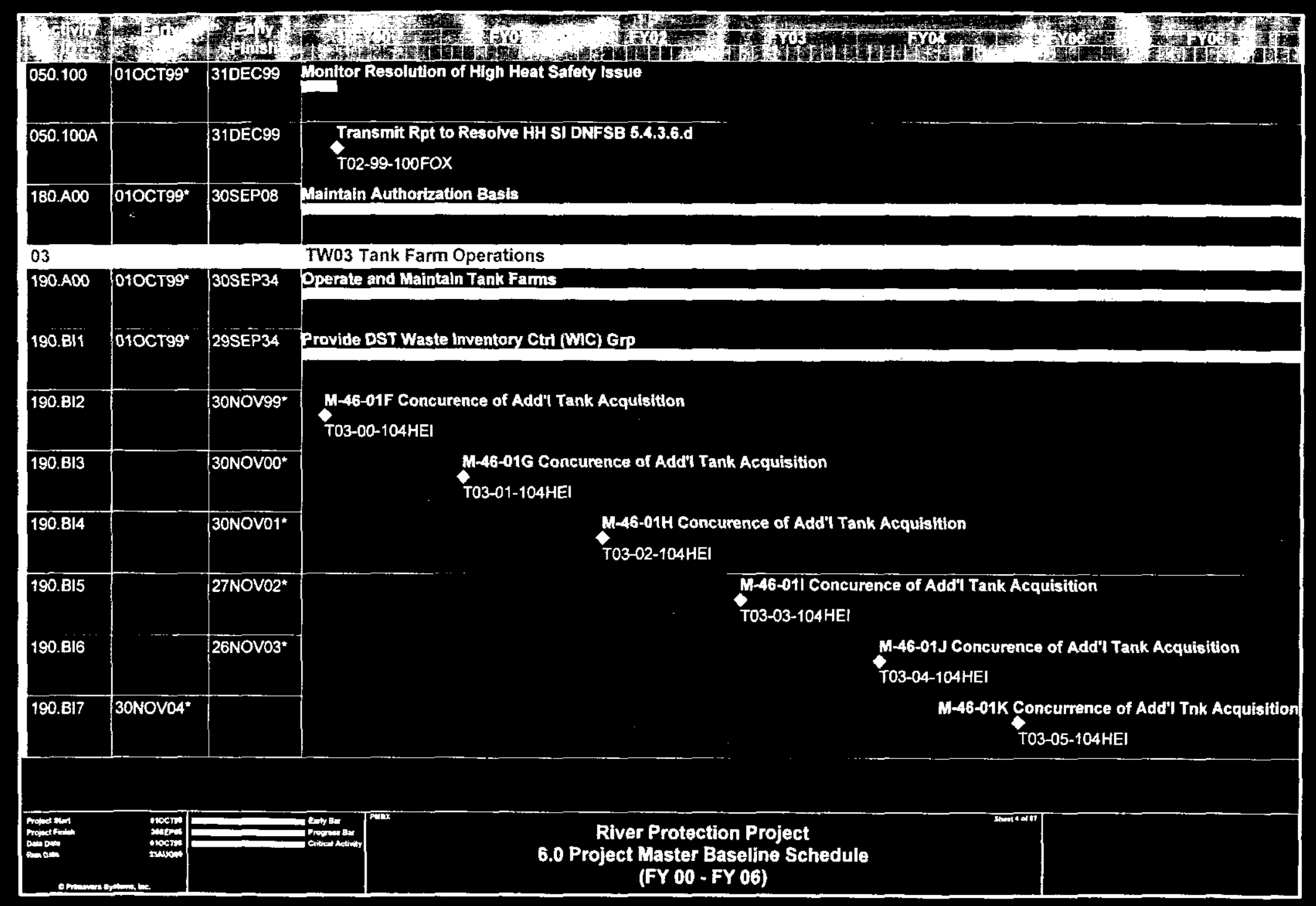




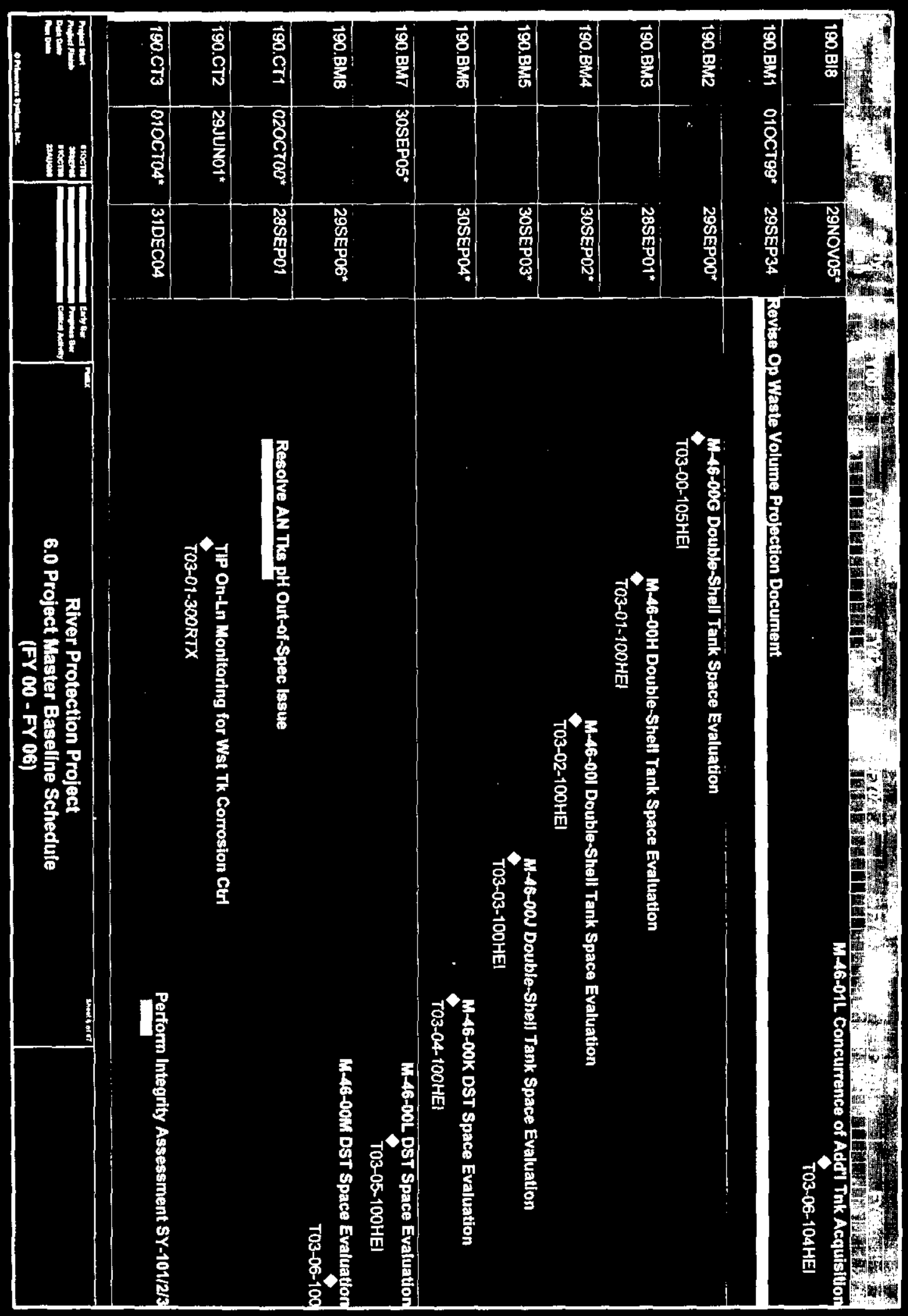




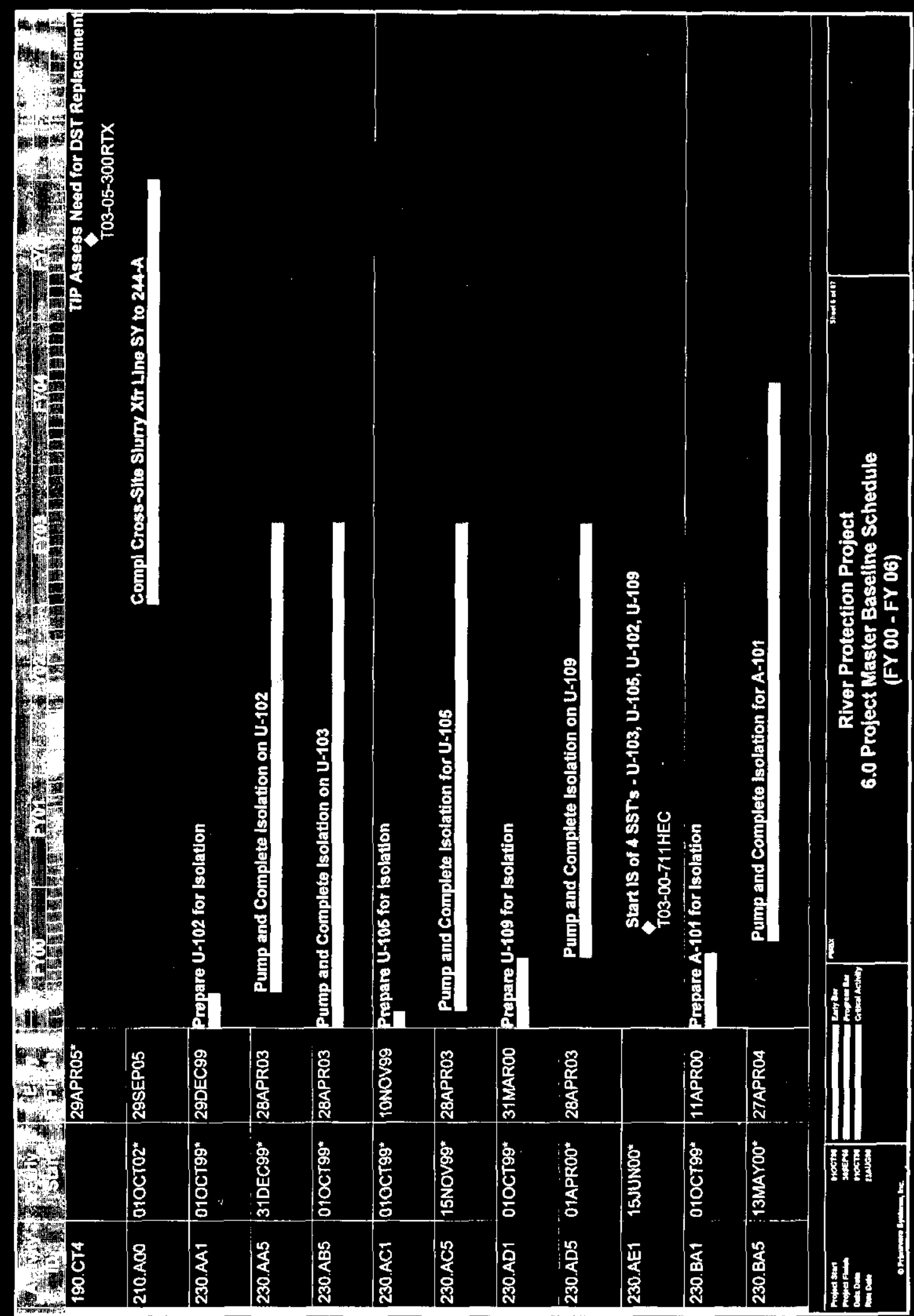


RPP-5044

6-8

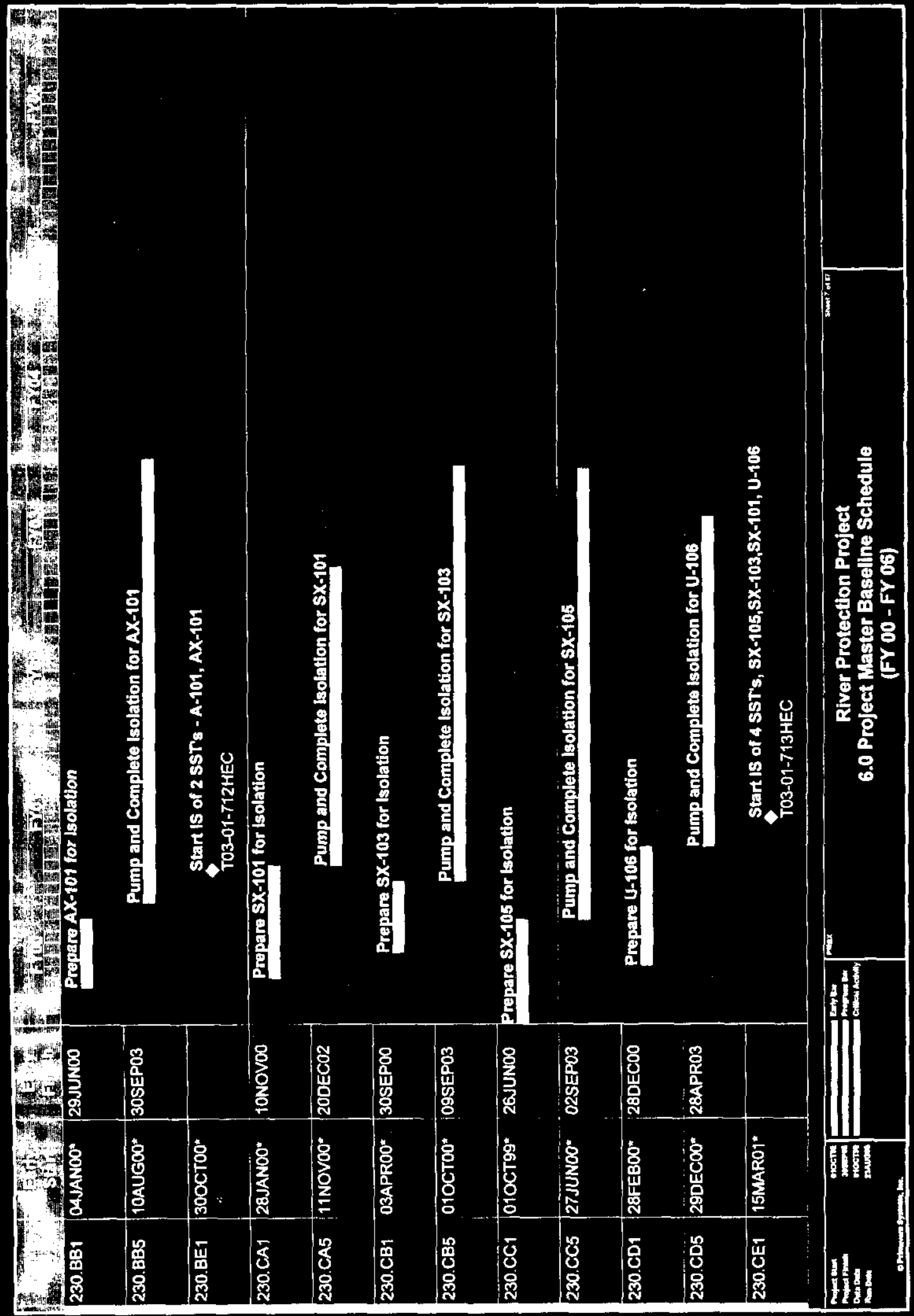




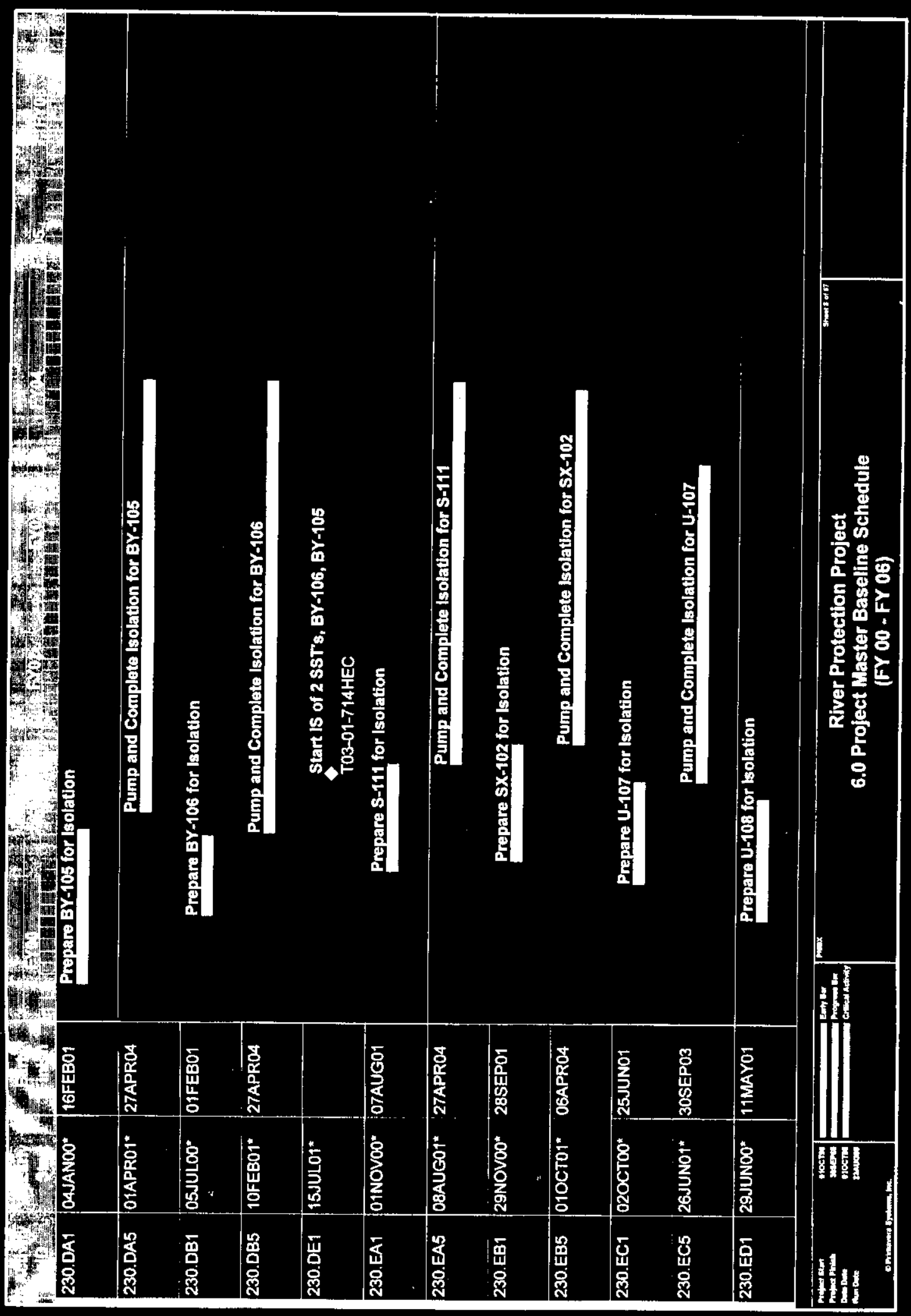


RPP-5044

6-10

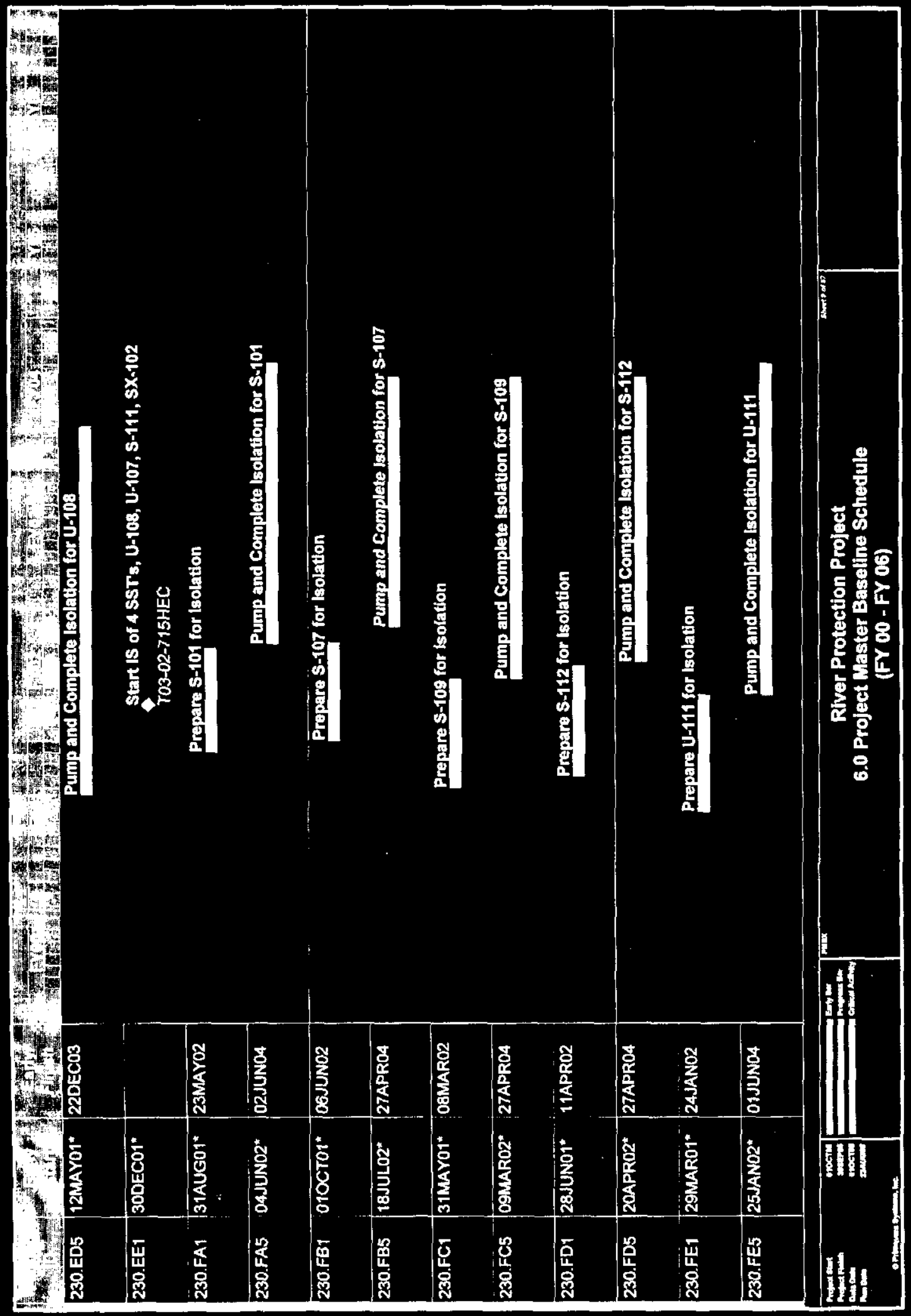




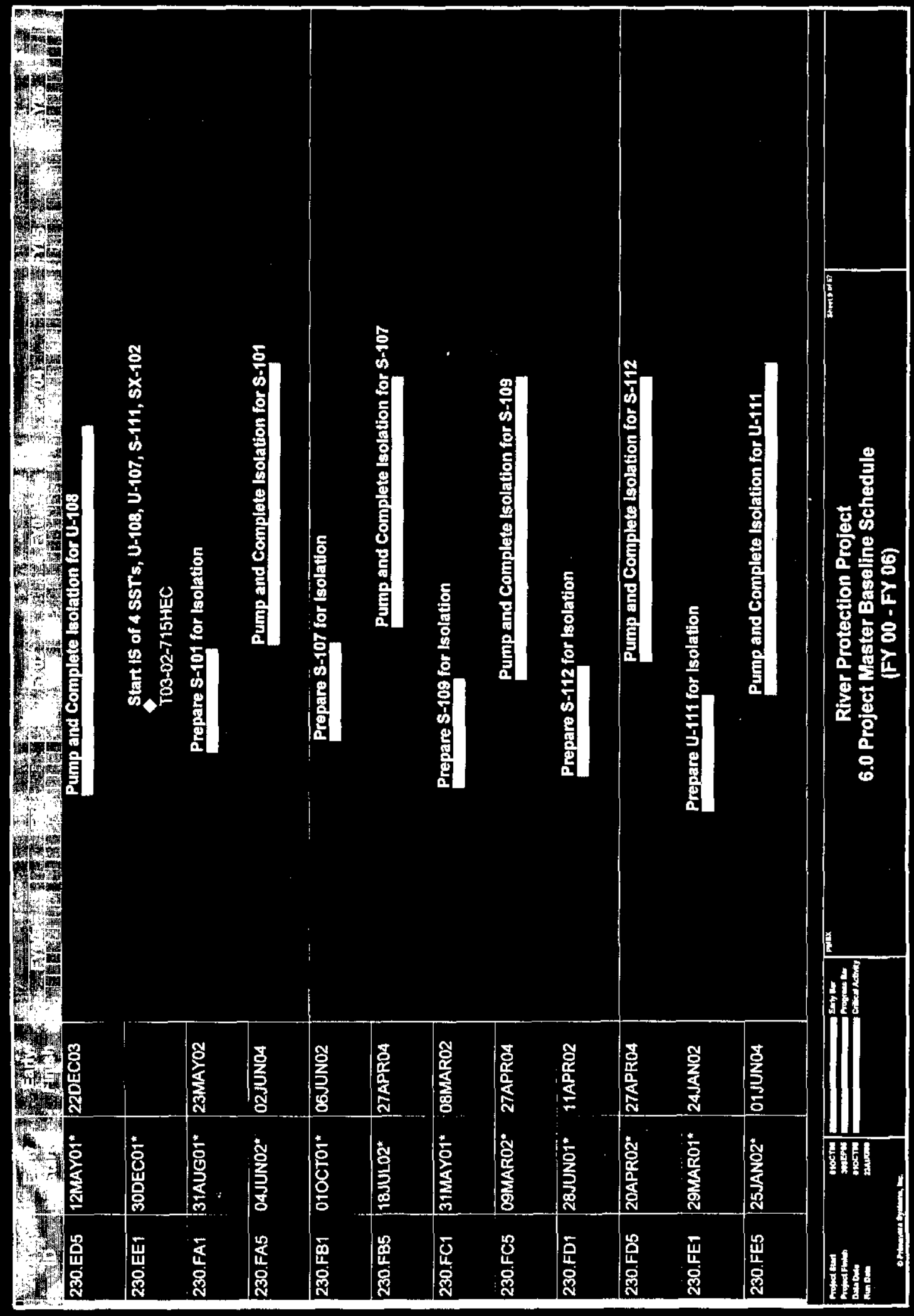




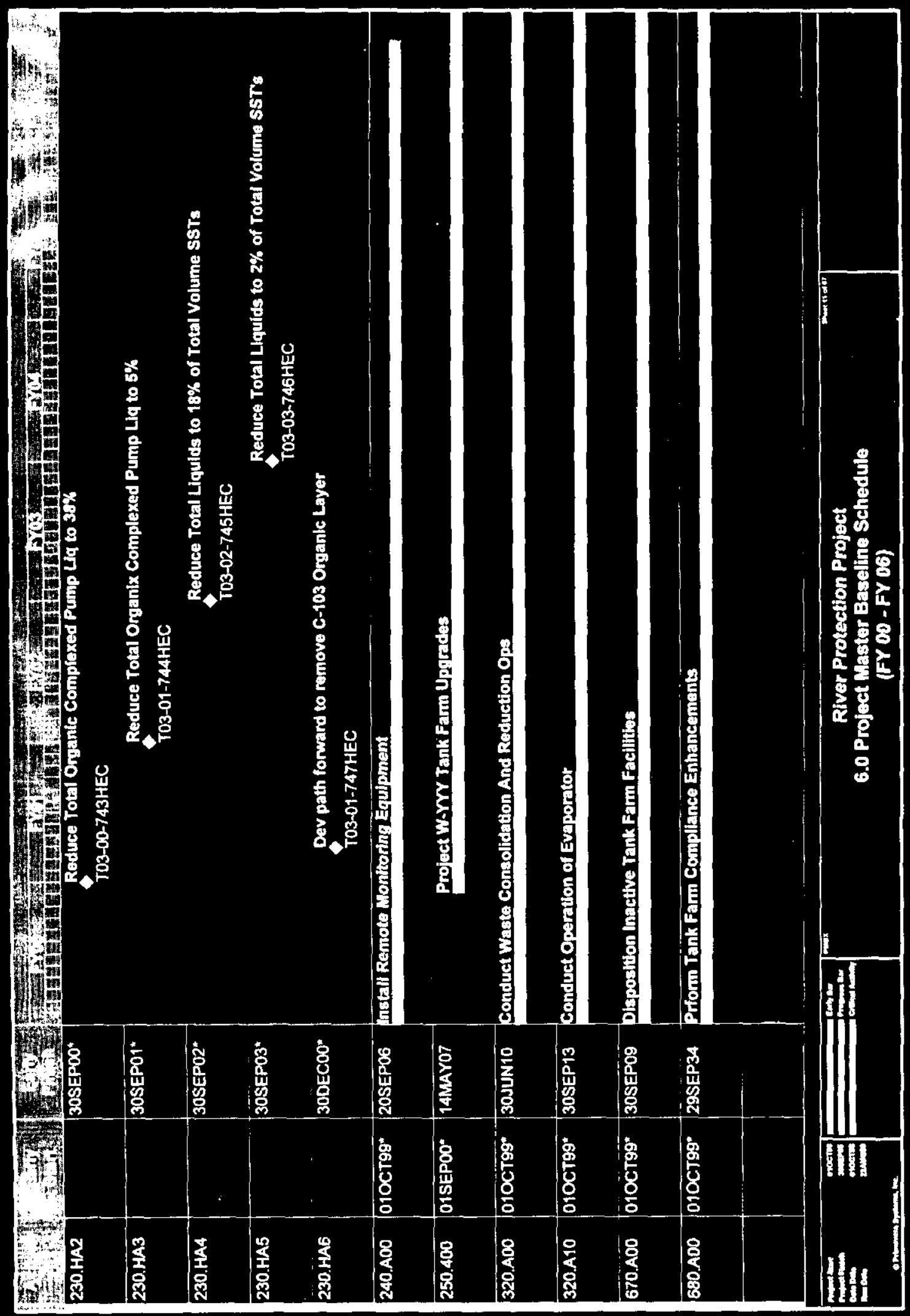




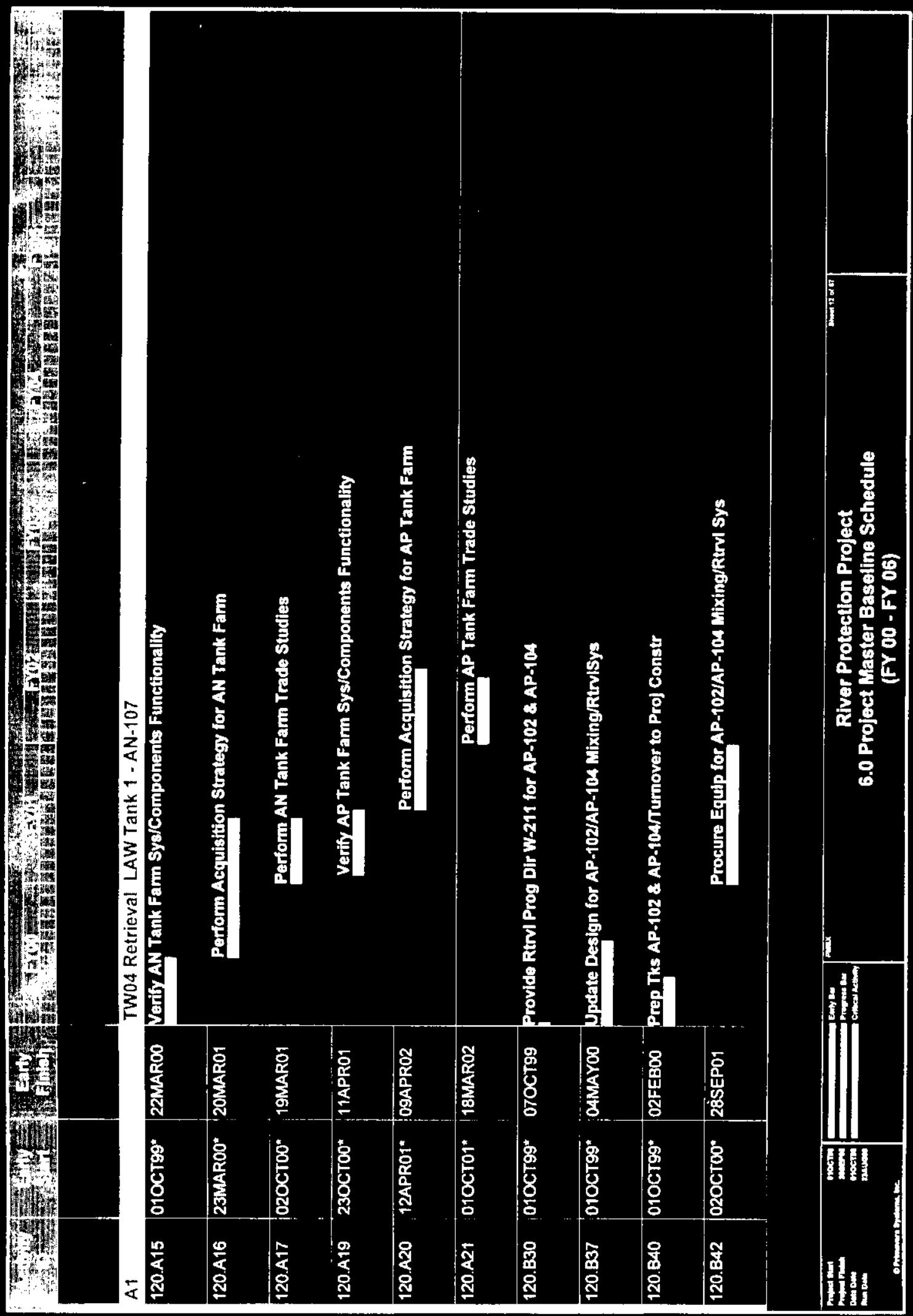


RPP-5044

6-14

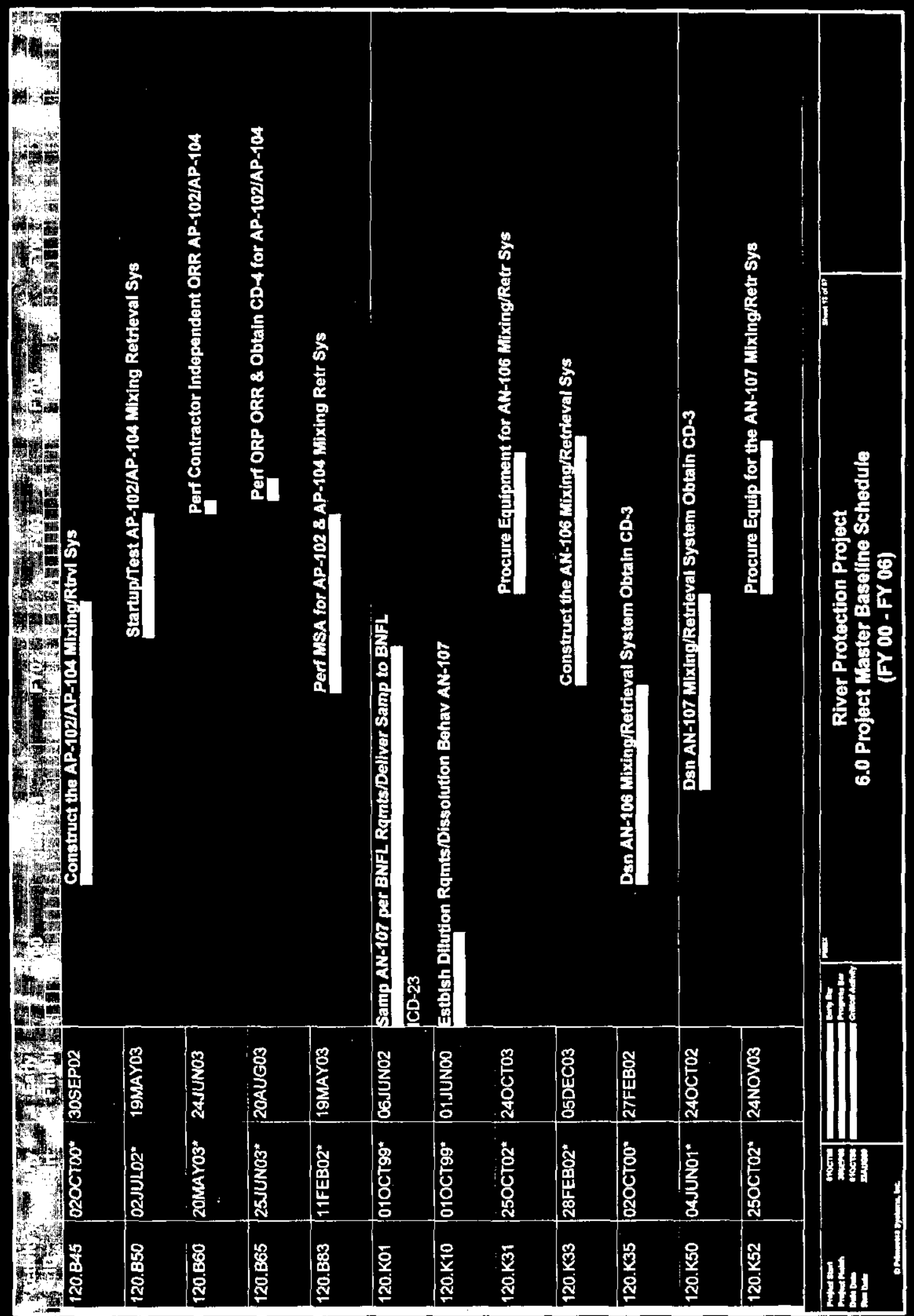




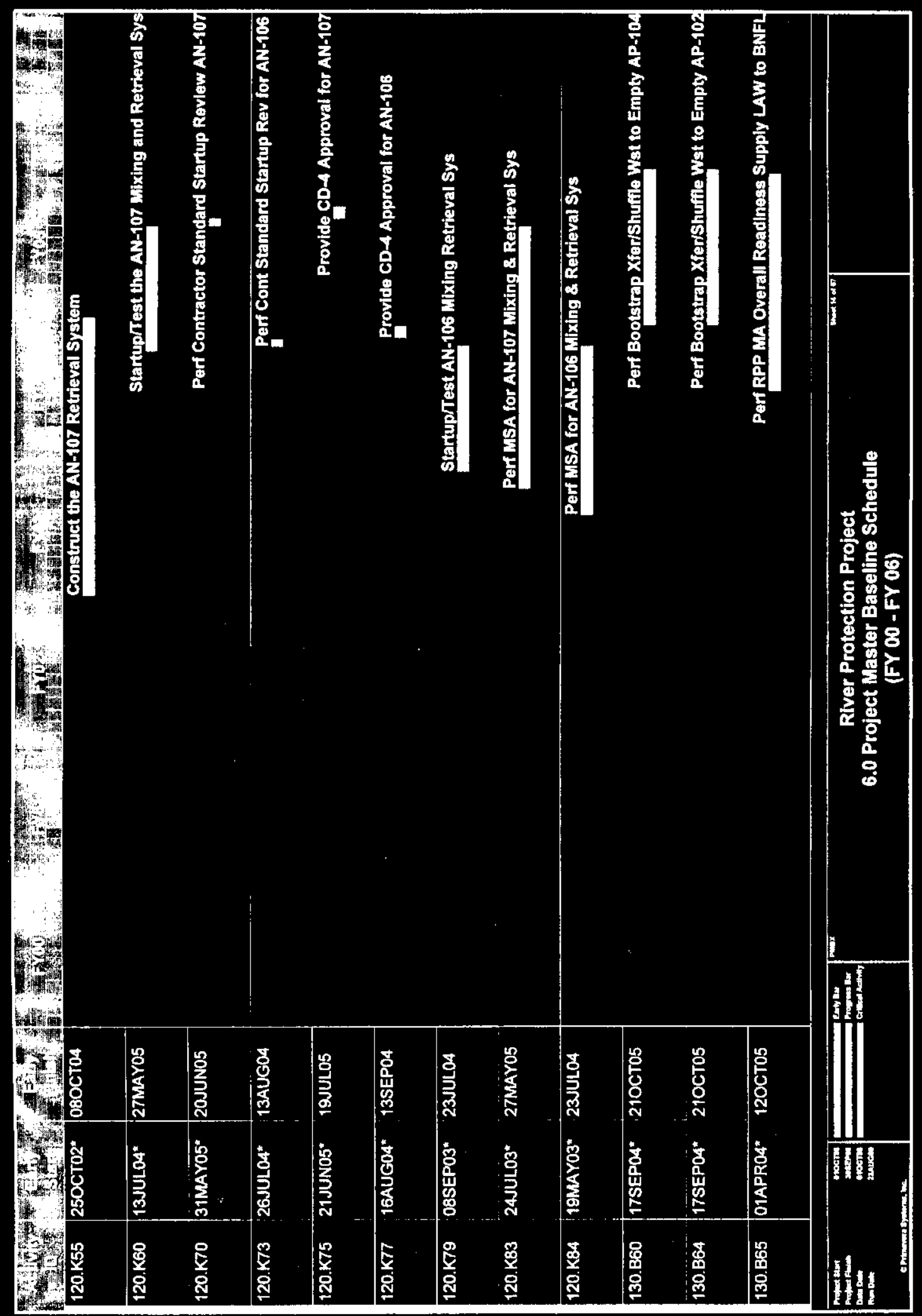


RPP-5044

6-16

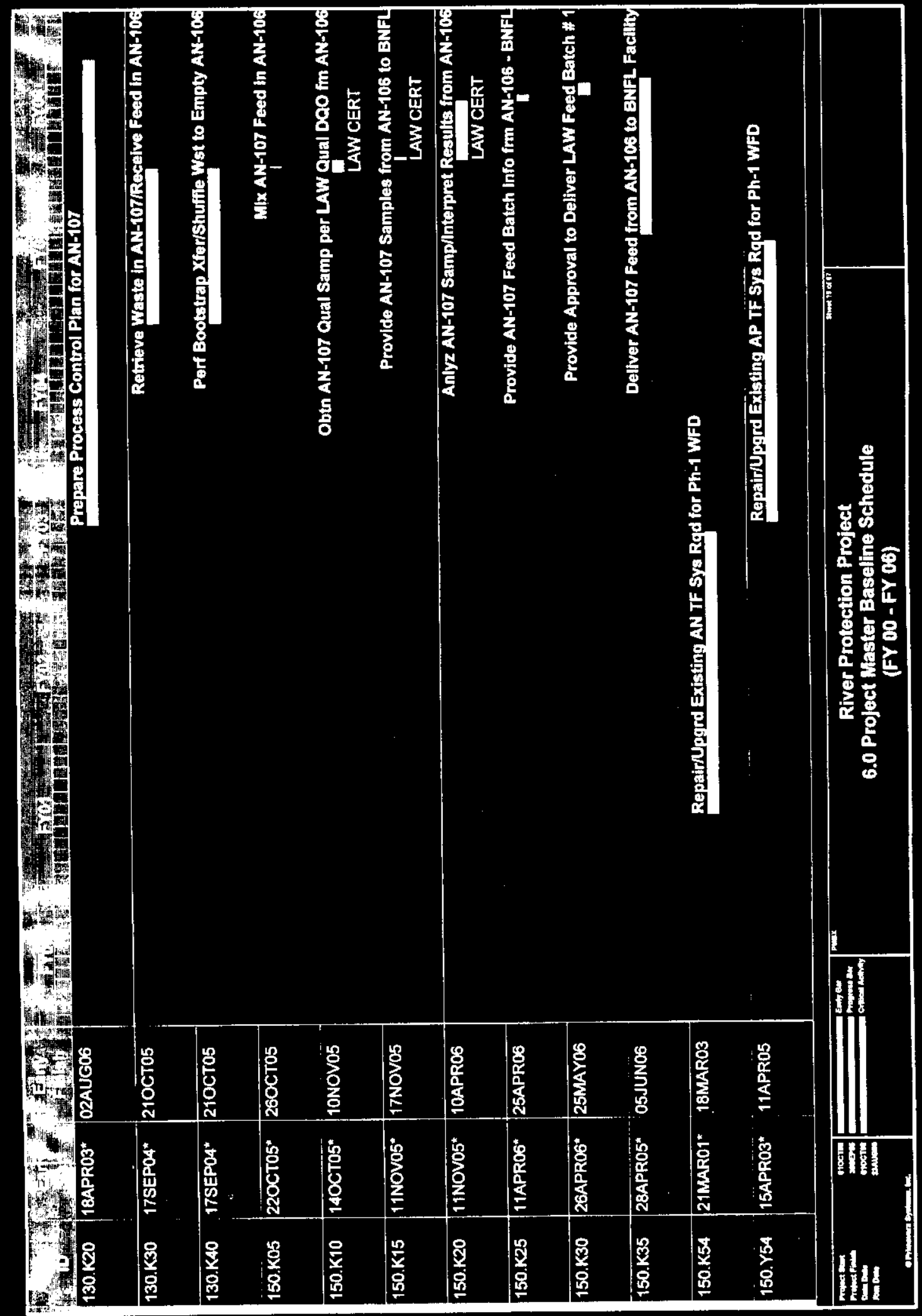




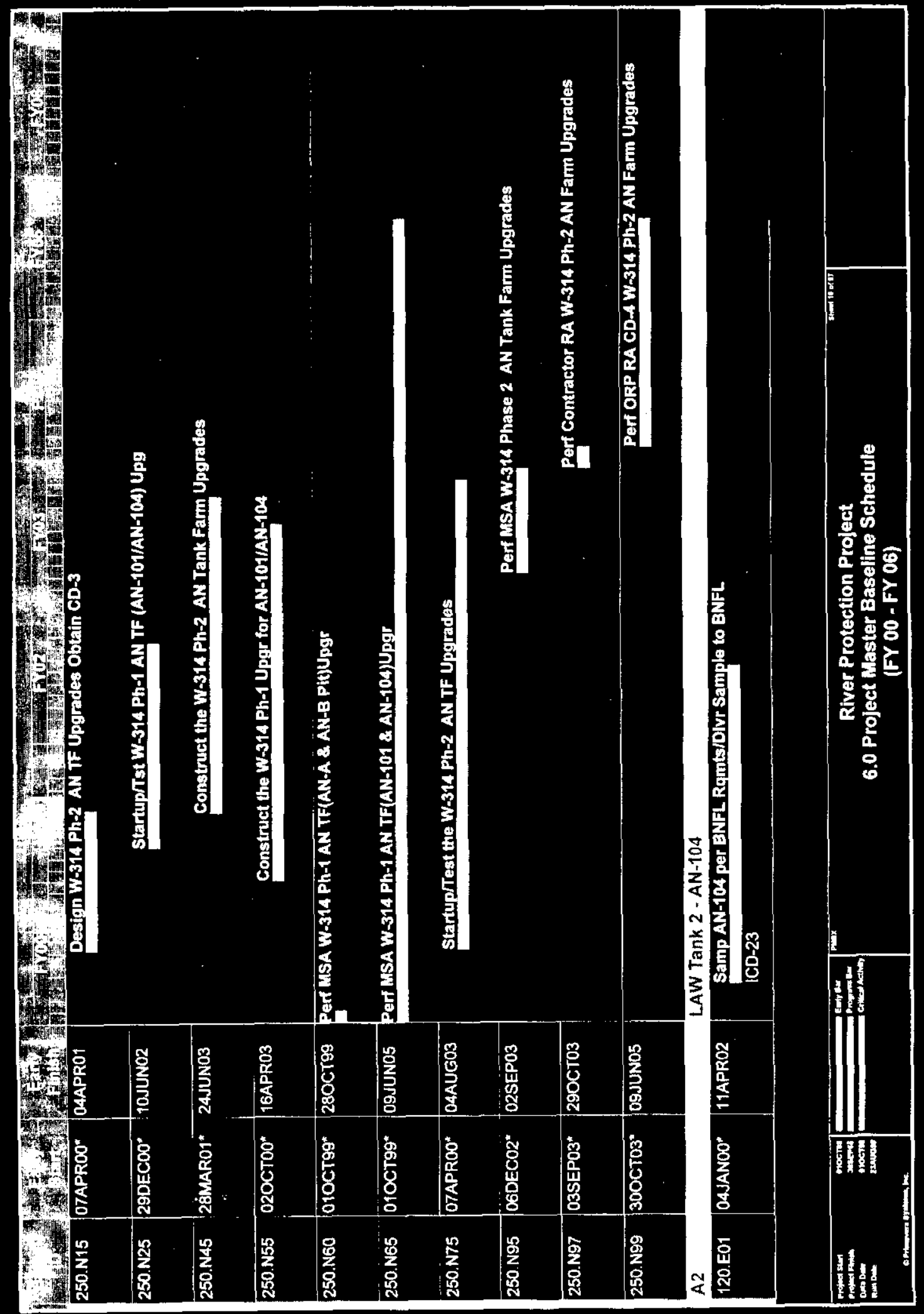


RPP-5044

6-18

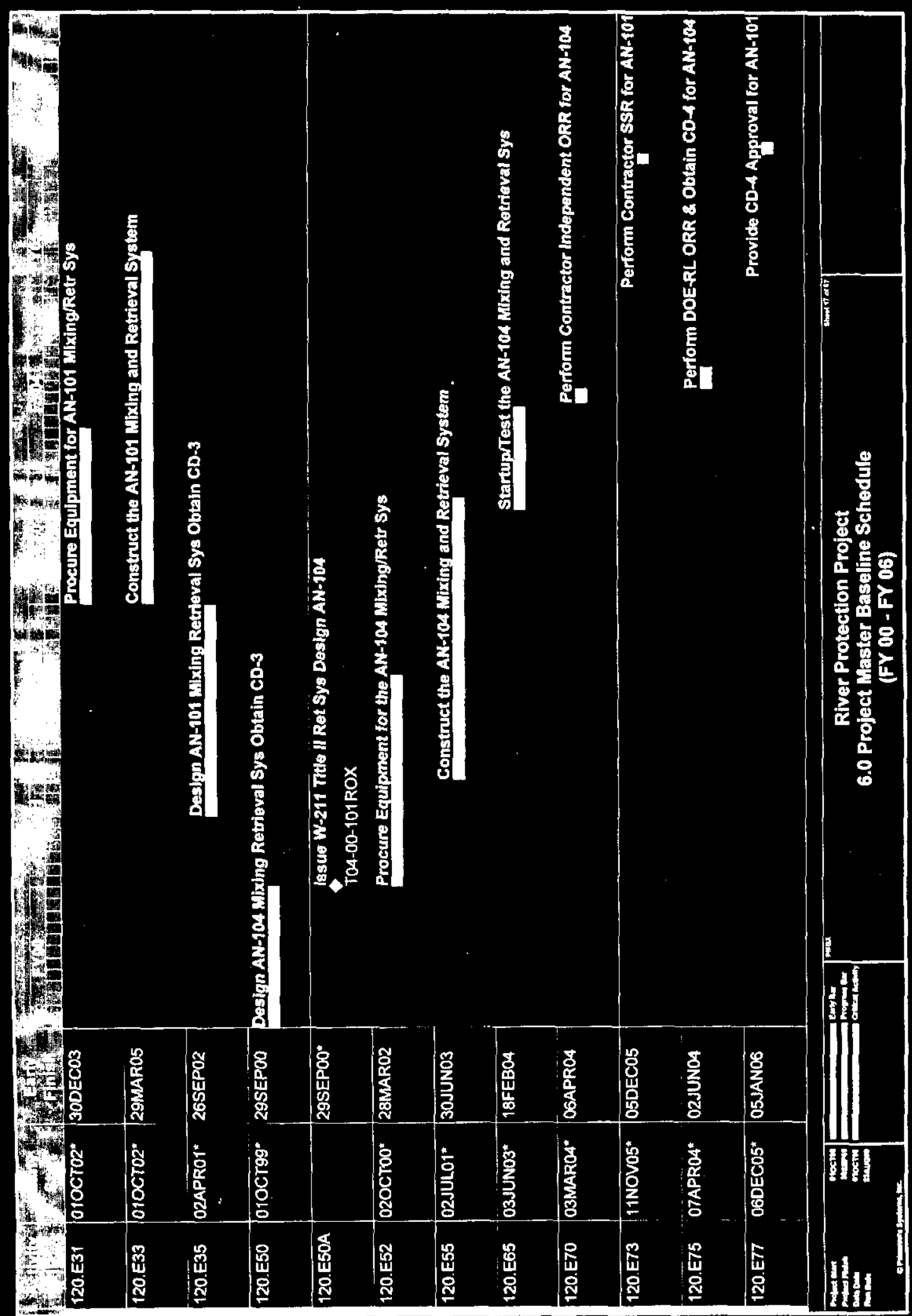




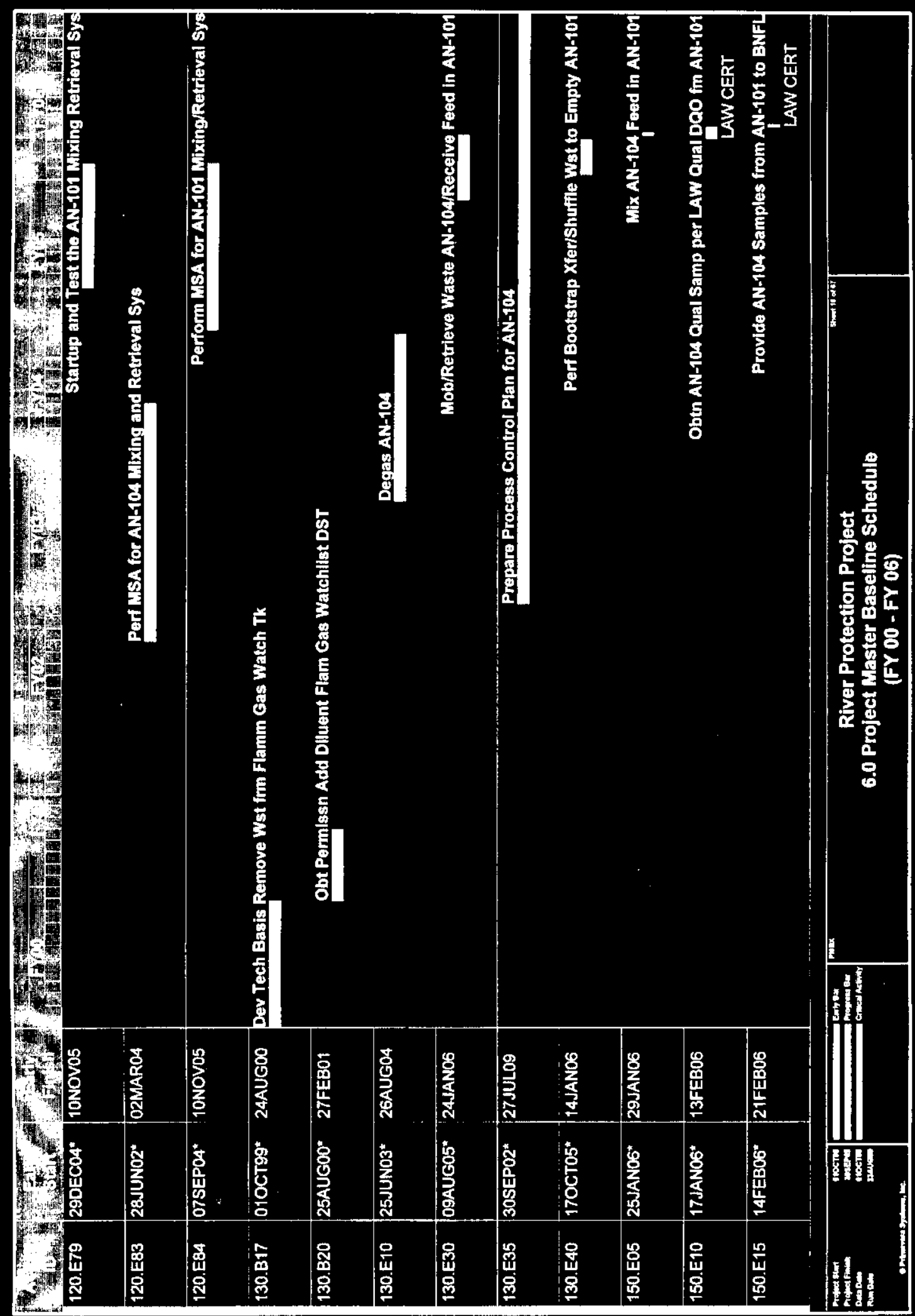




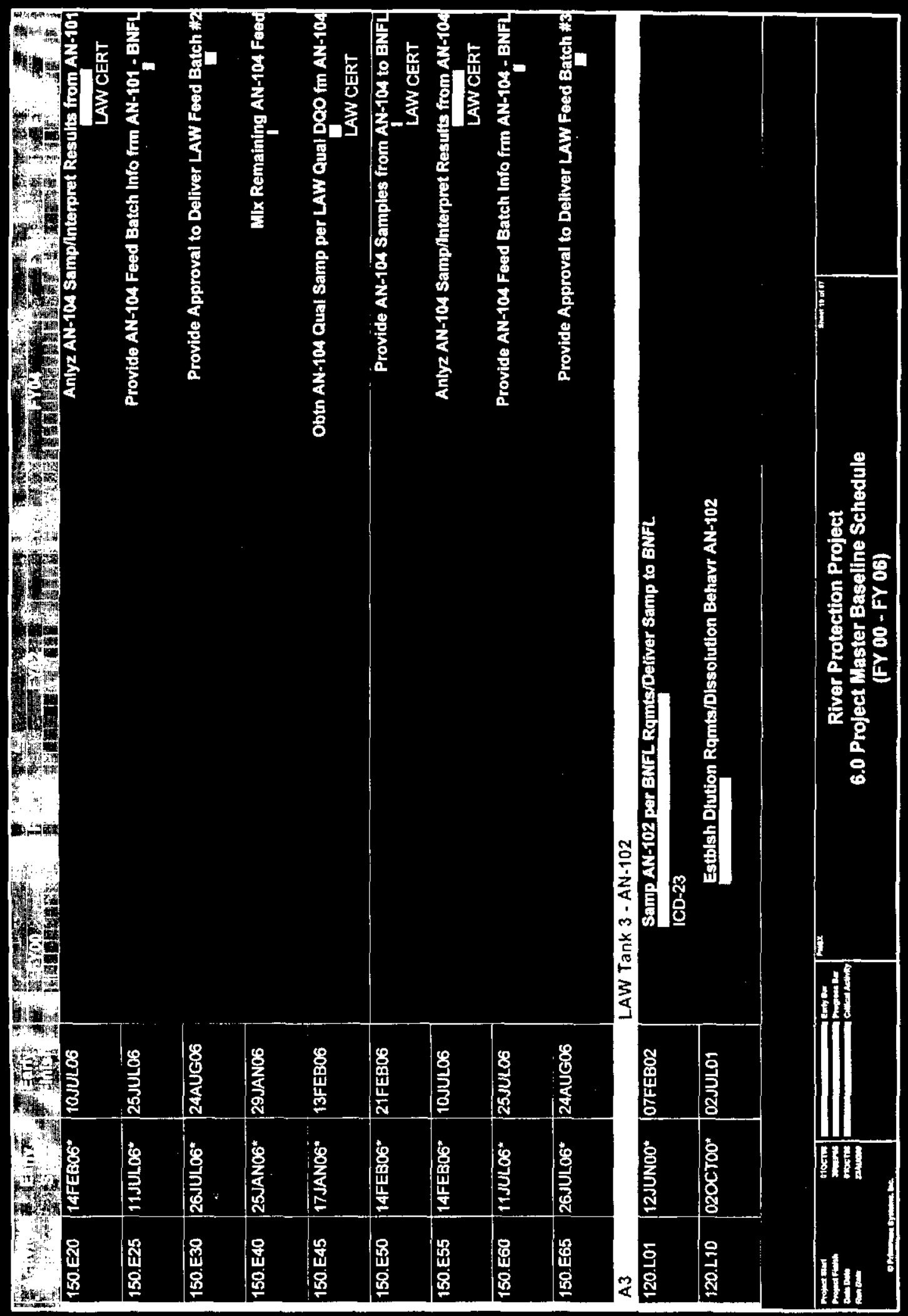




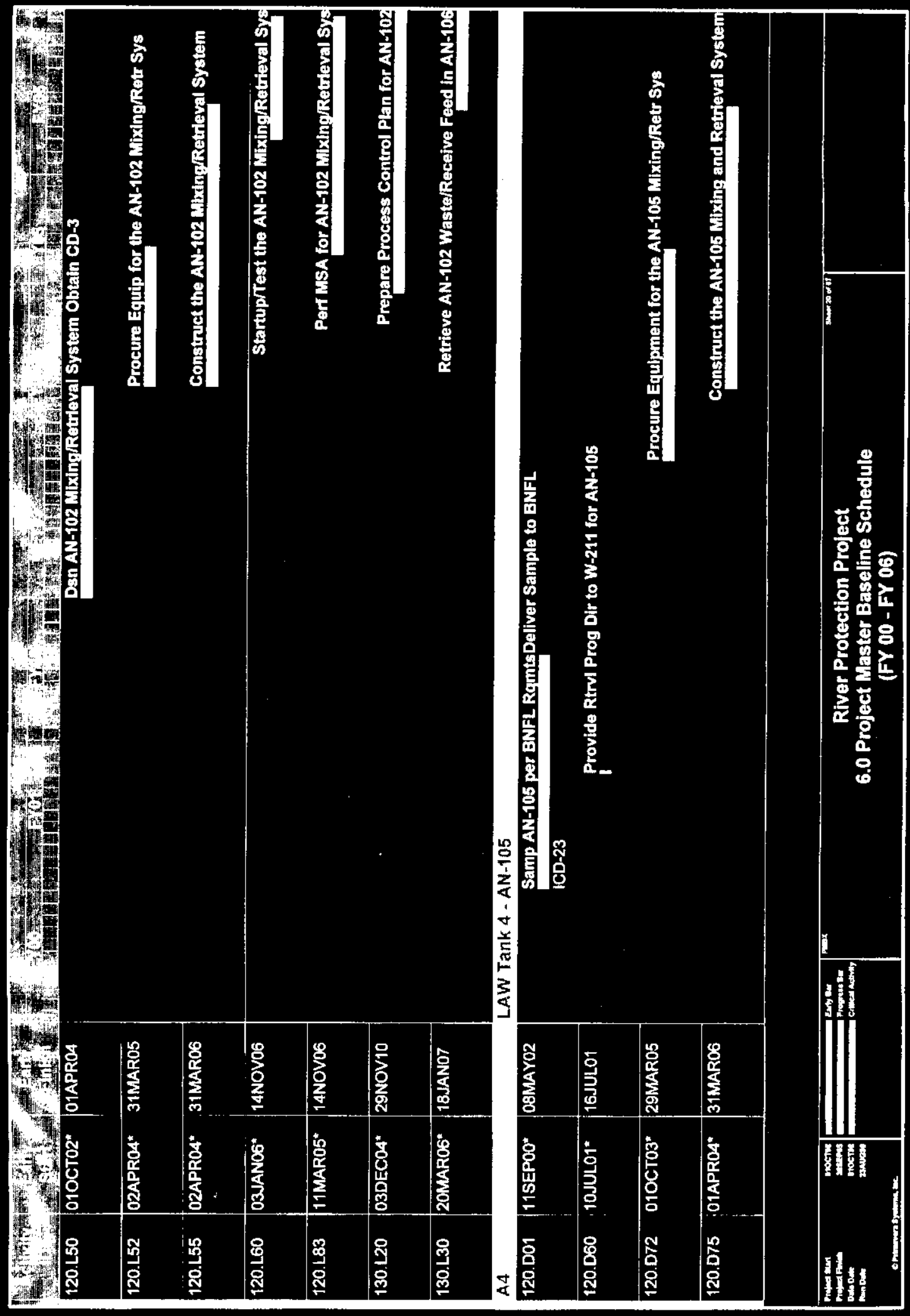


RPP-5044

6-22

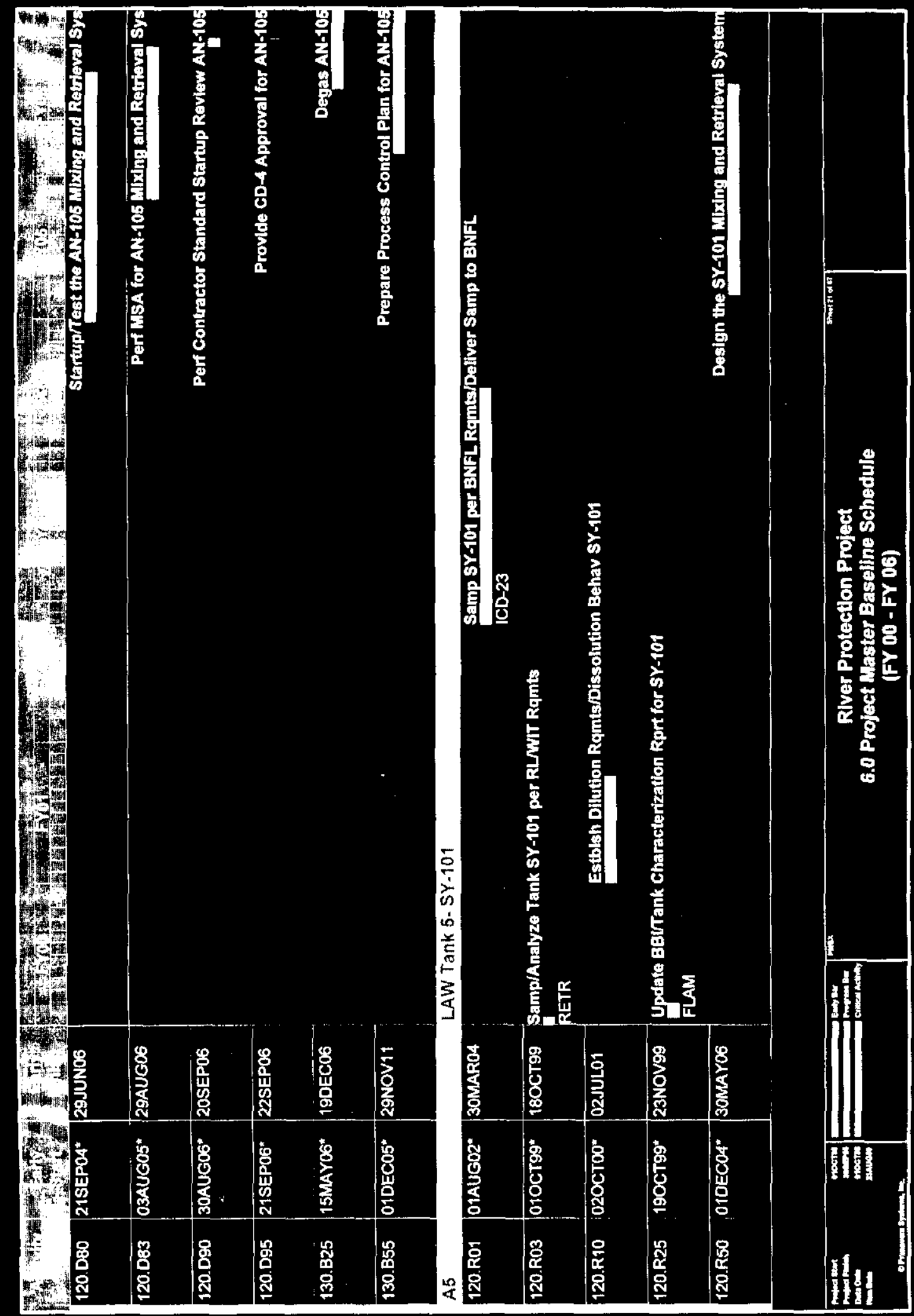




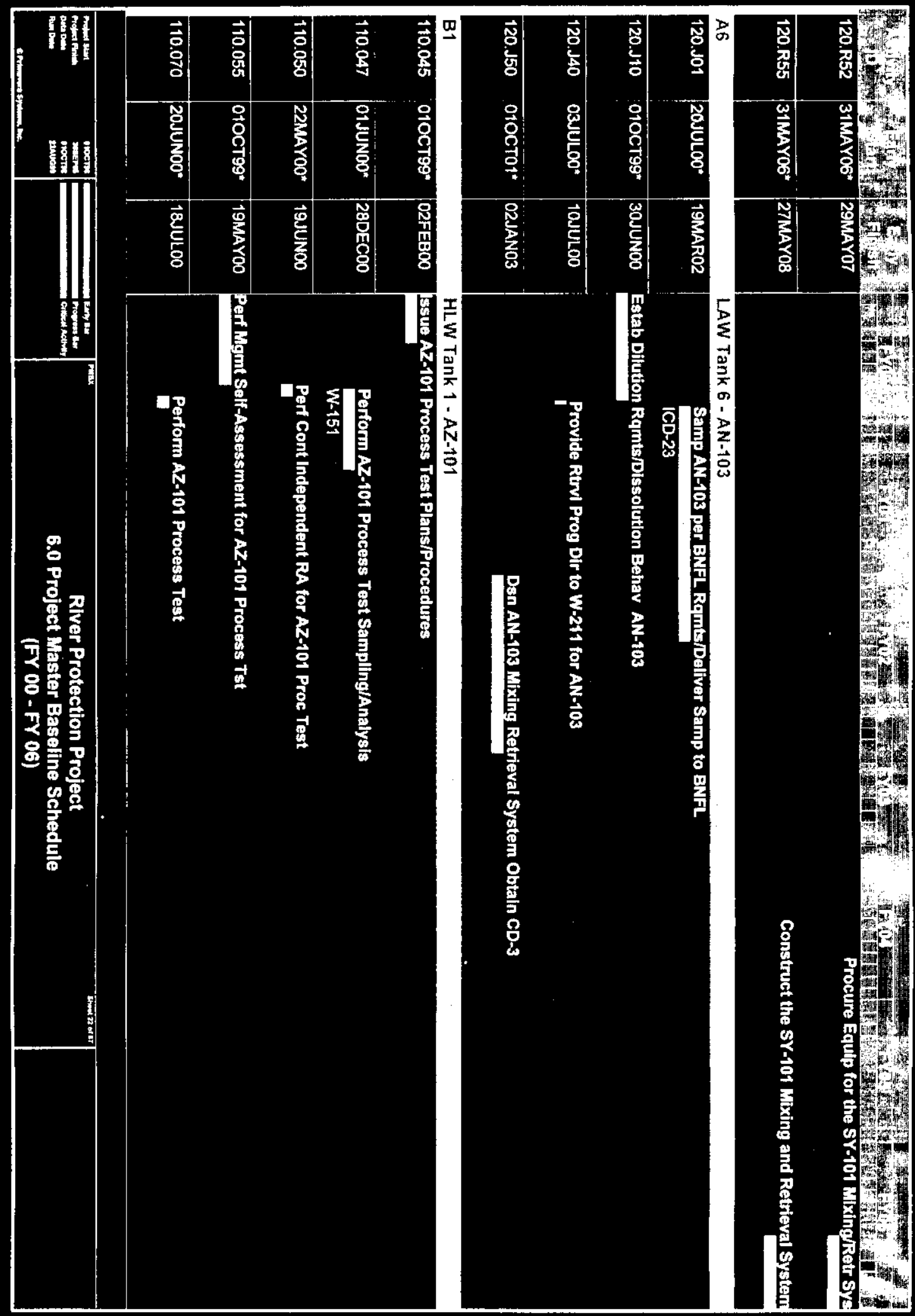

$\varepsilon Z-9$

$\downarrow \downarrow 0 S-d d y$ 
RPP-5044

6-24

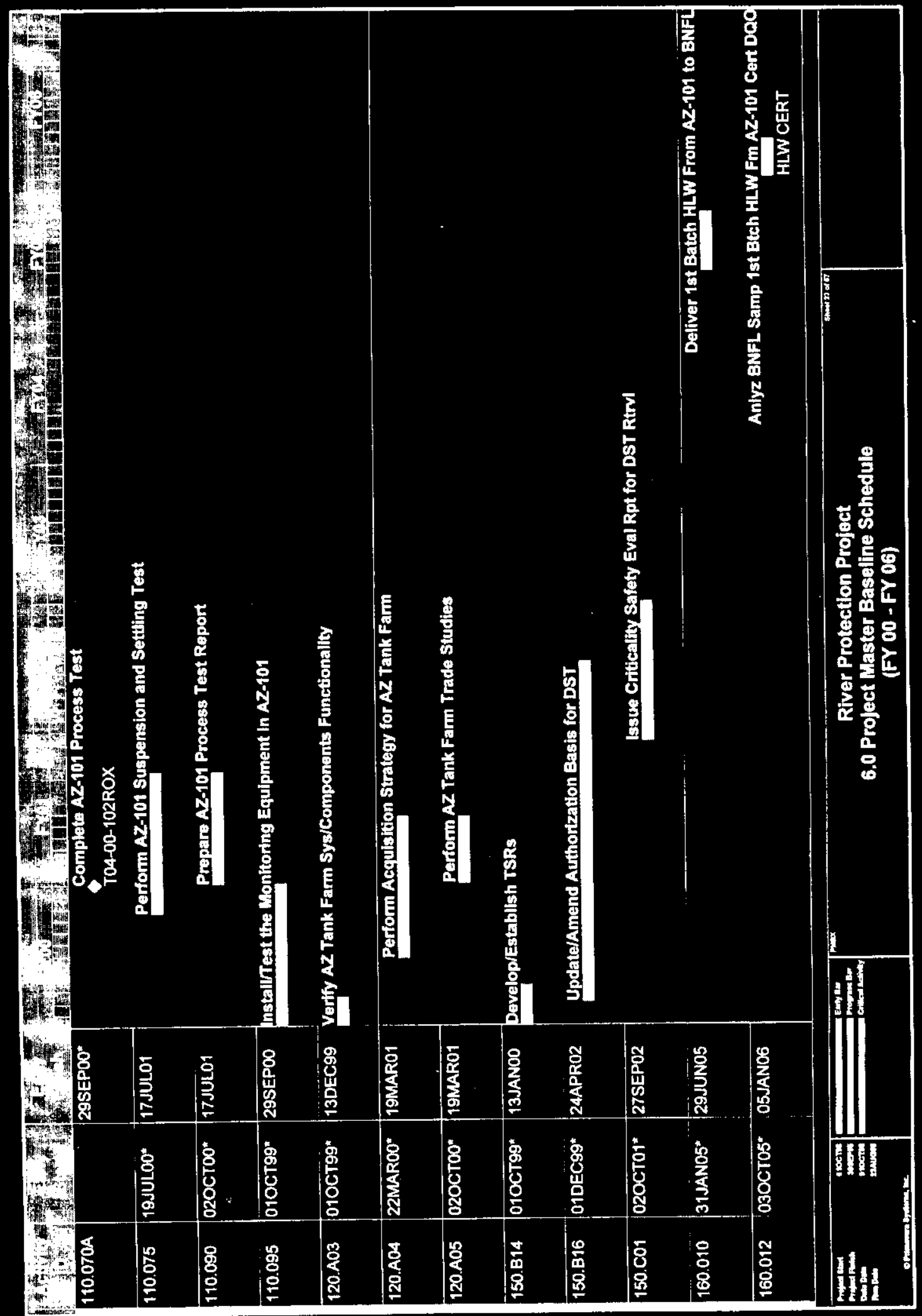




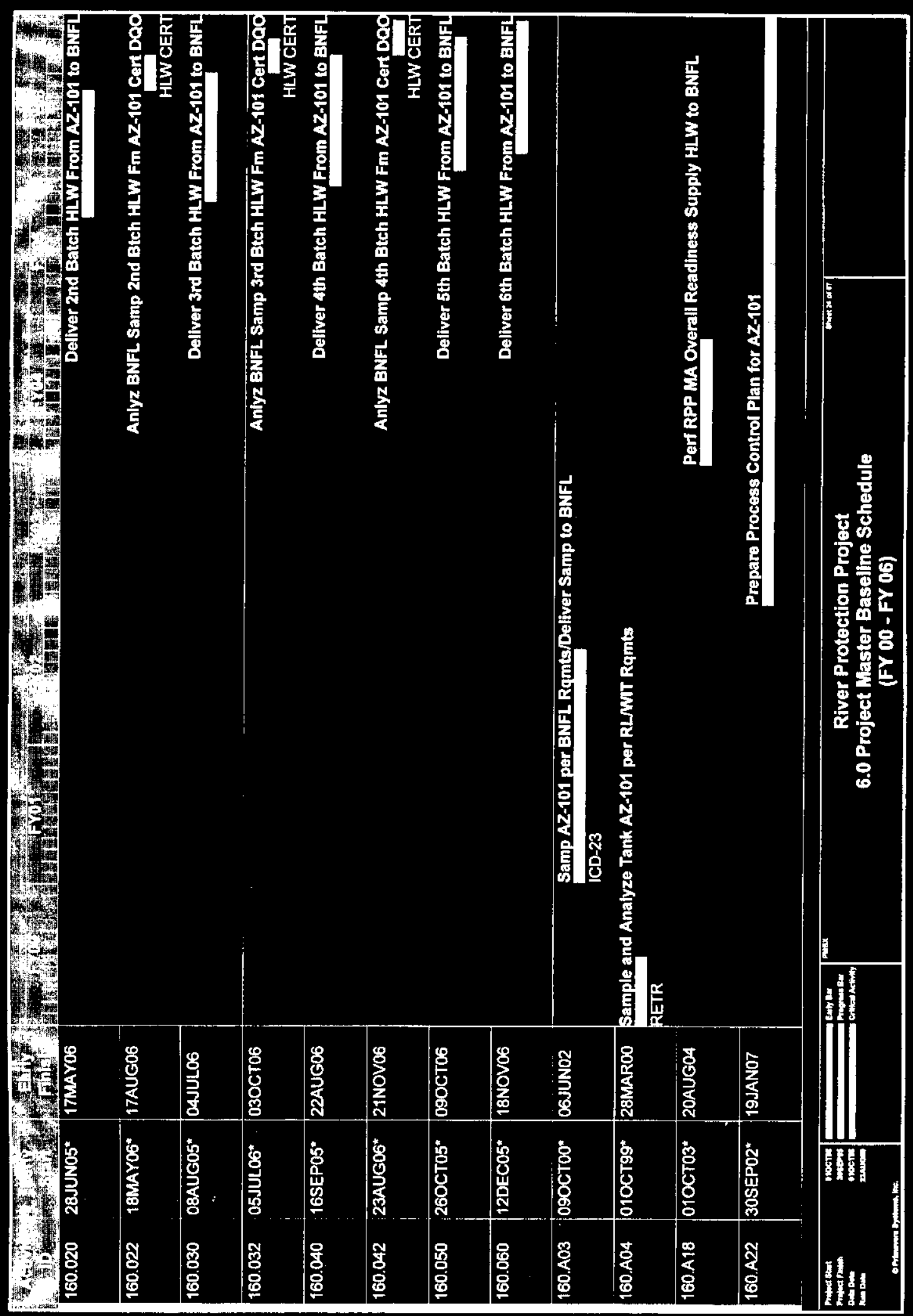


RPP-5044

6-26

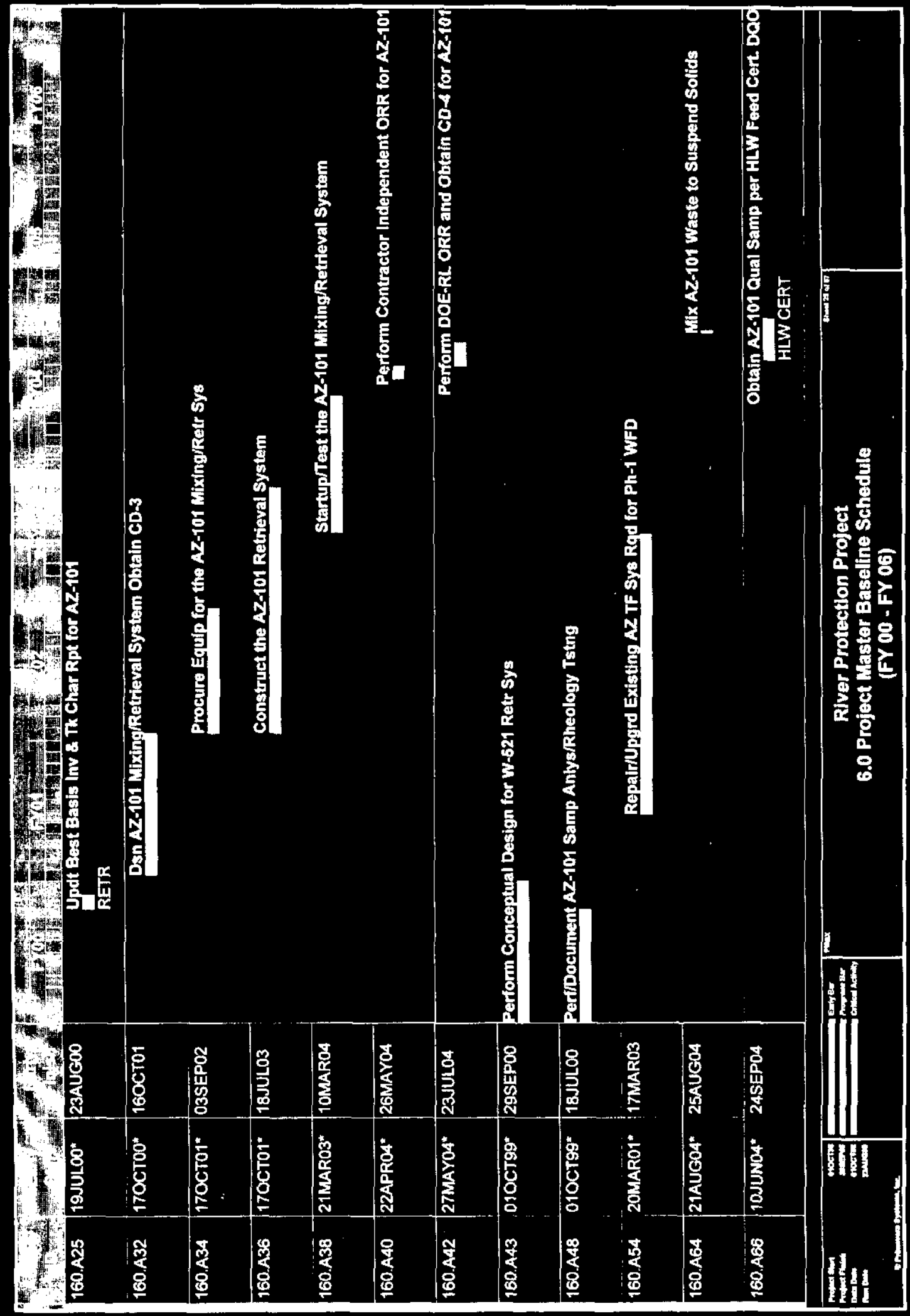




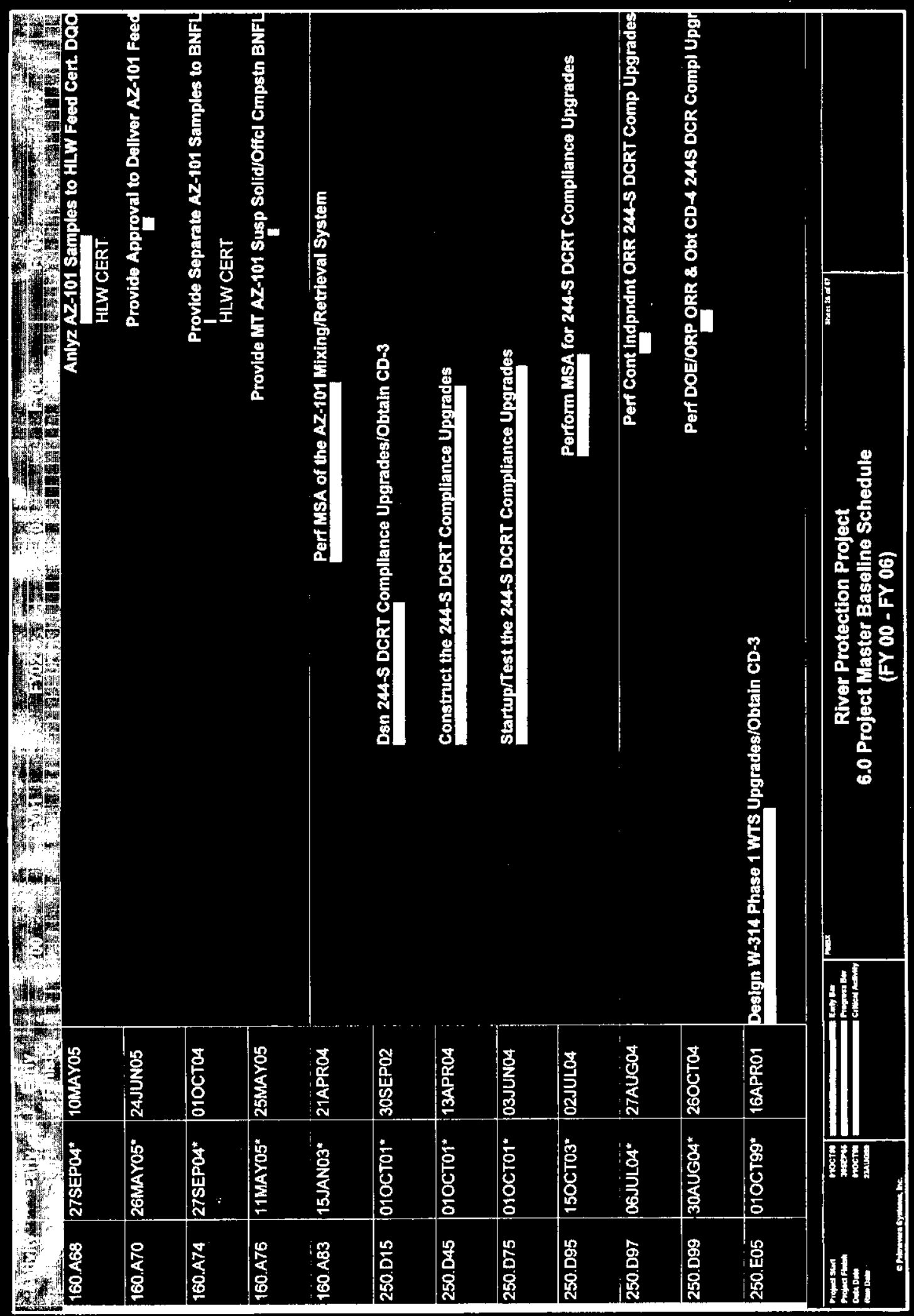


RPP-5044

6-28

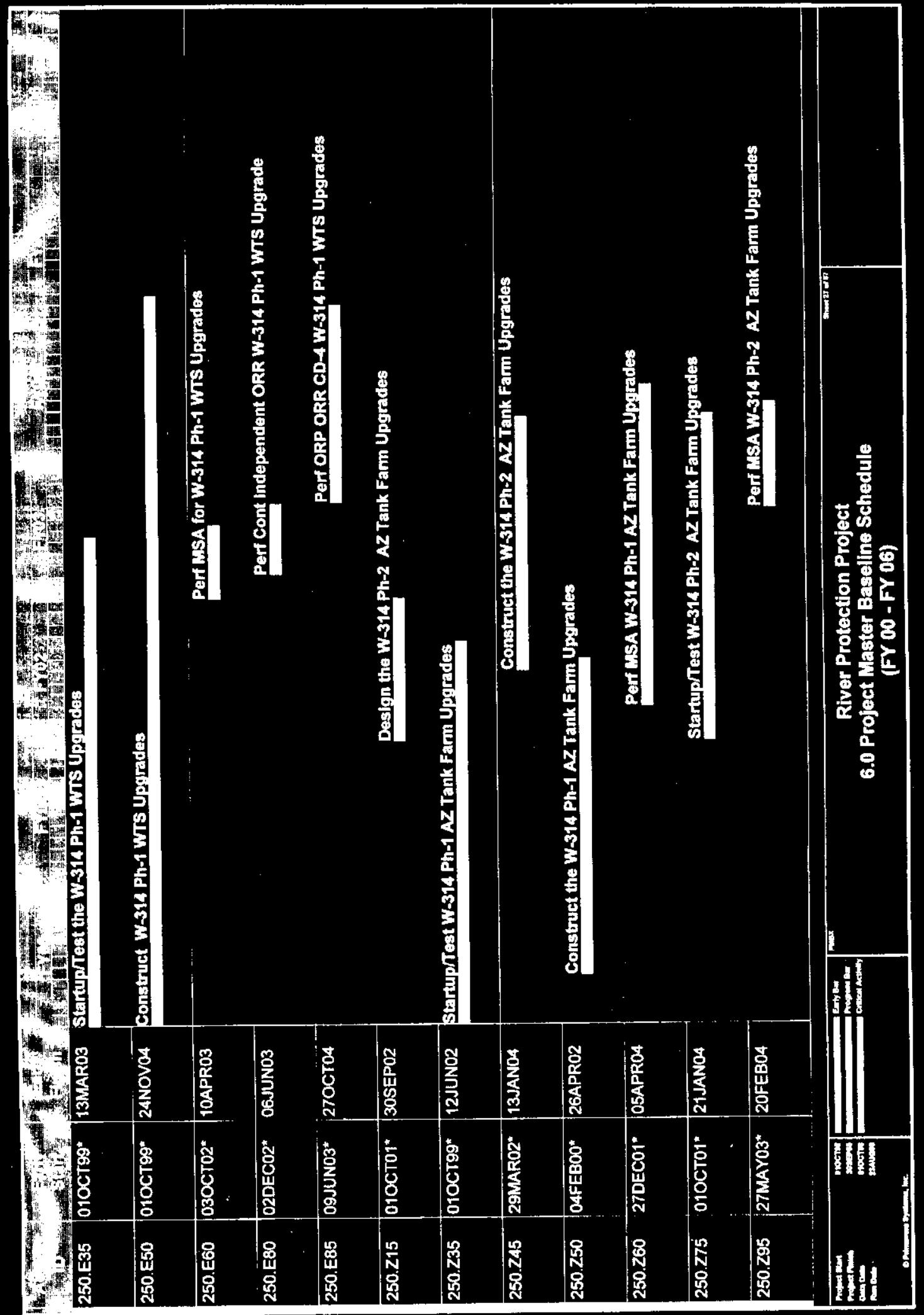




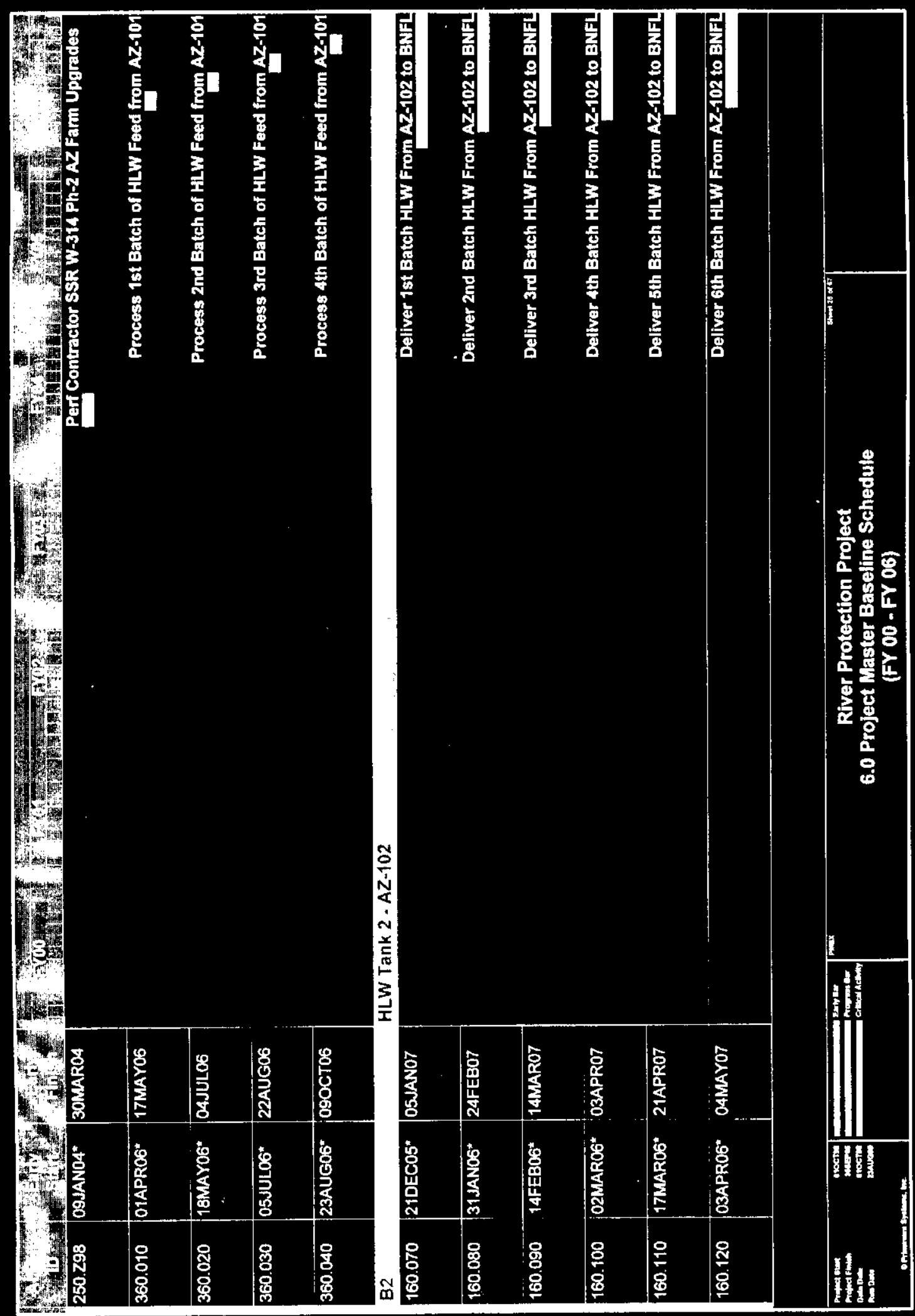




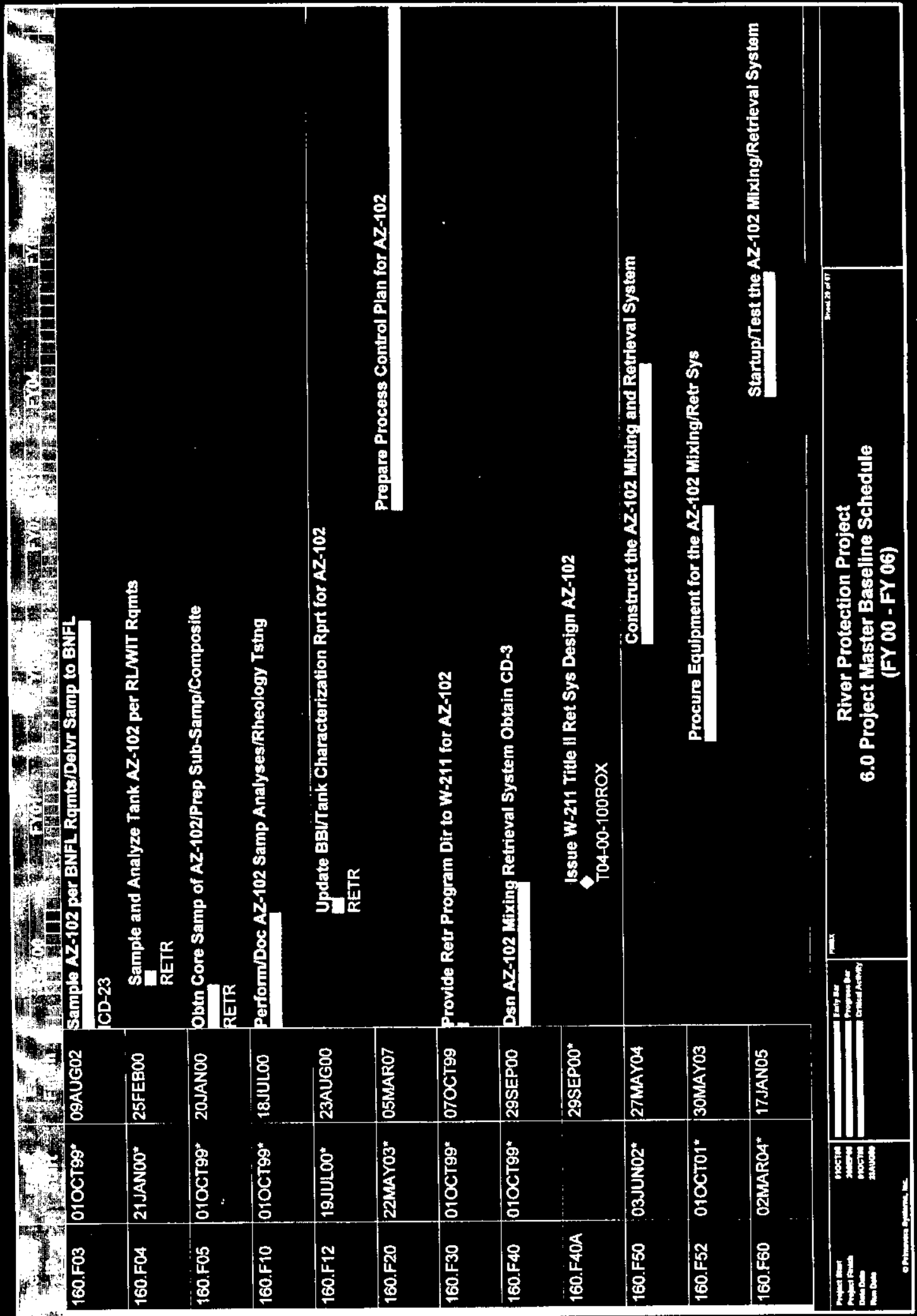




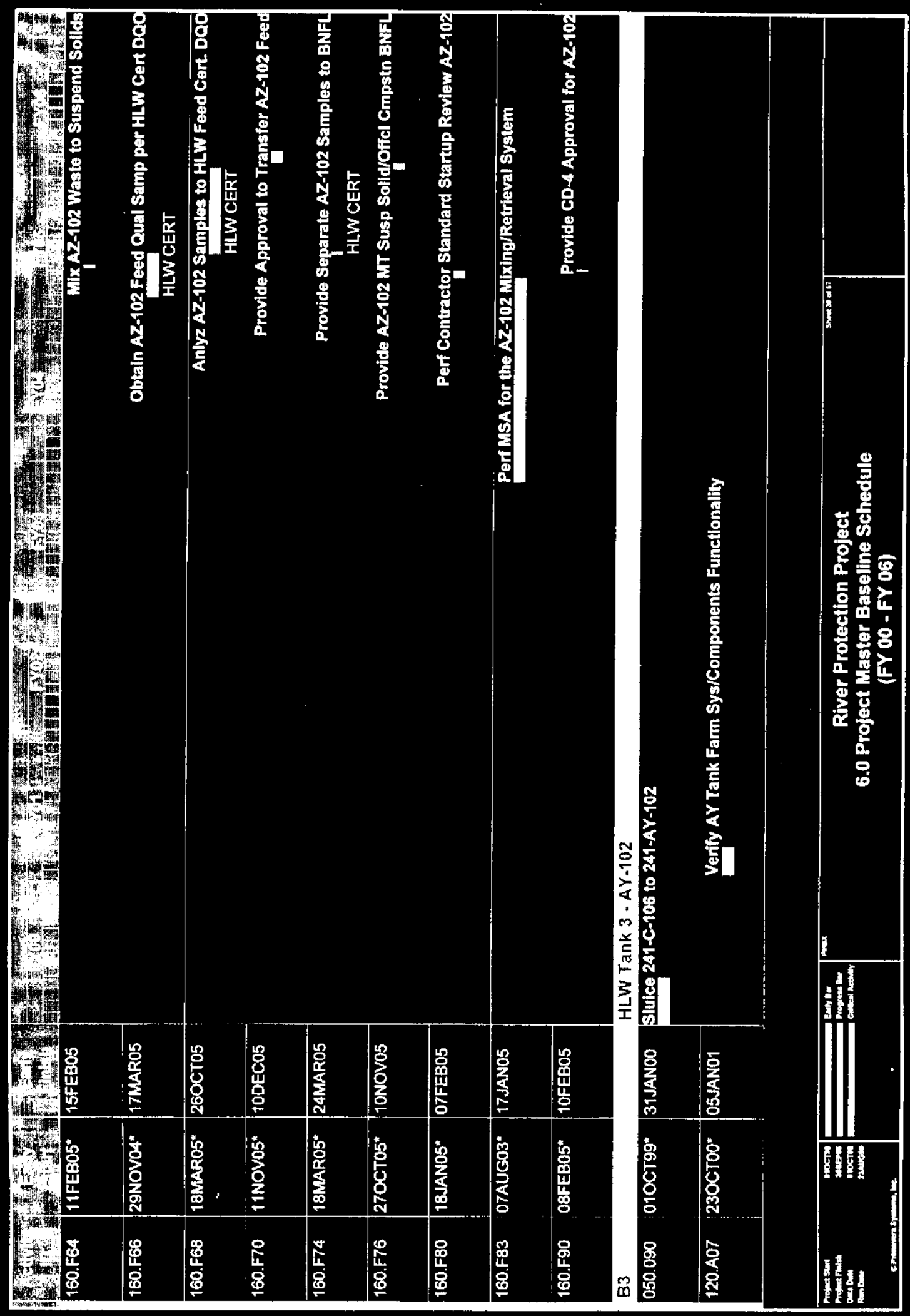




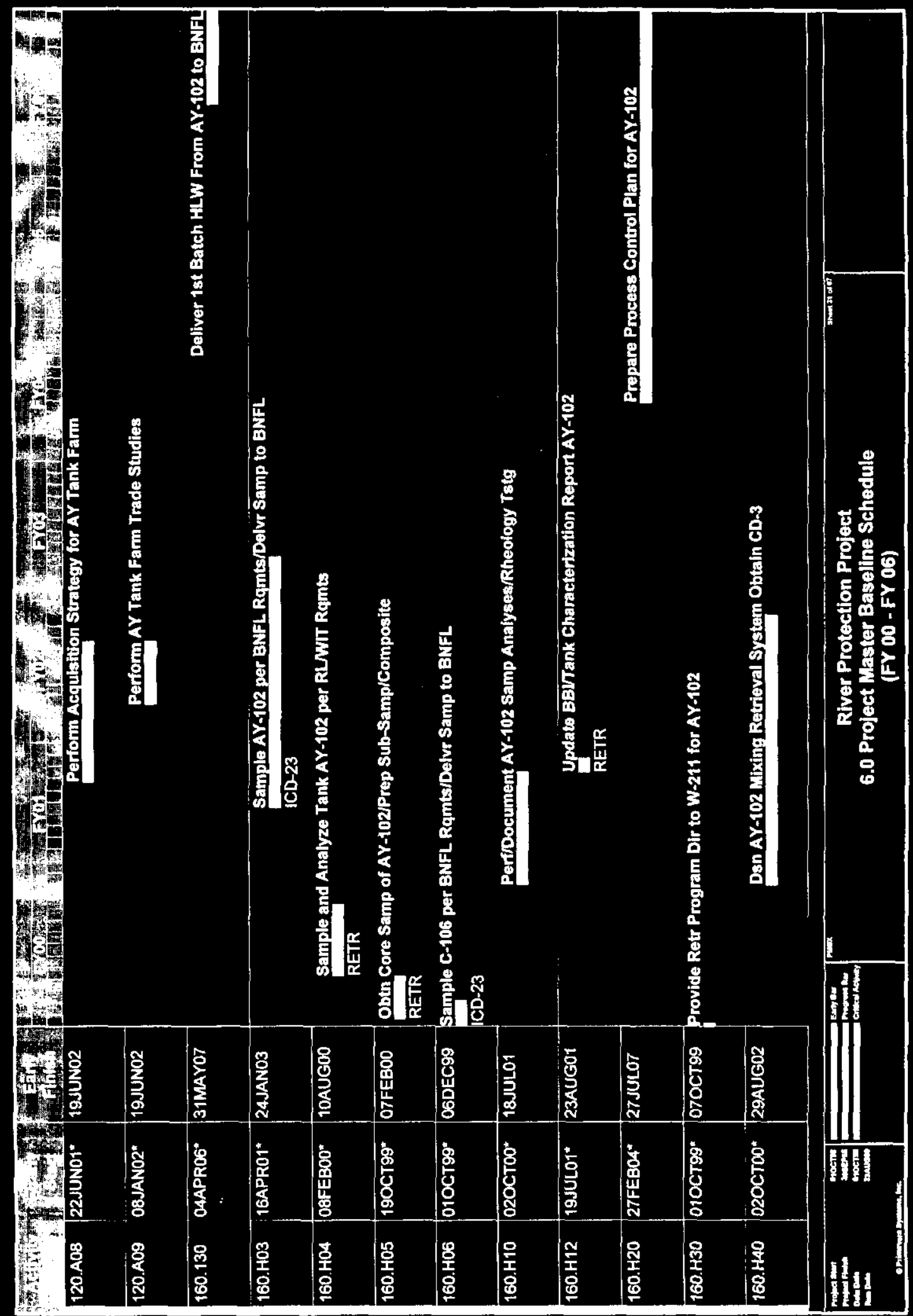




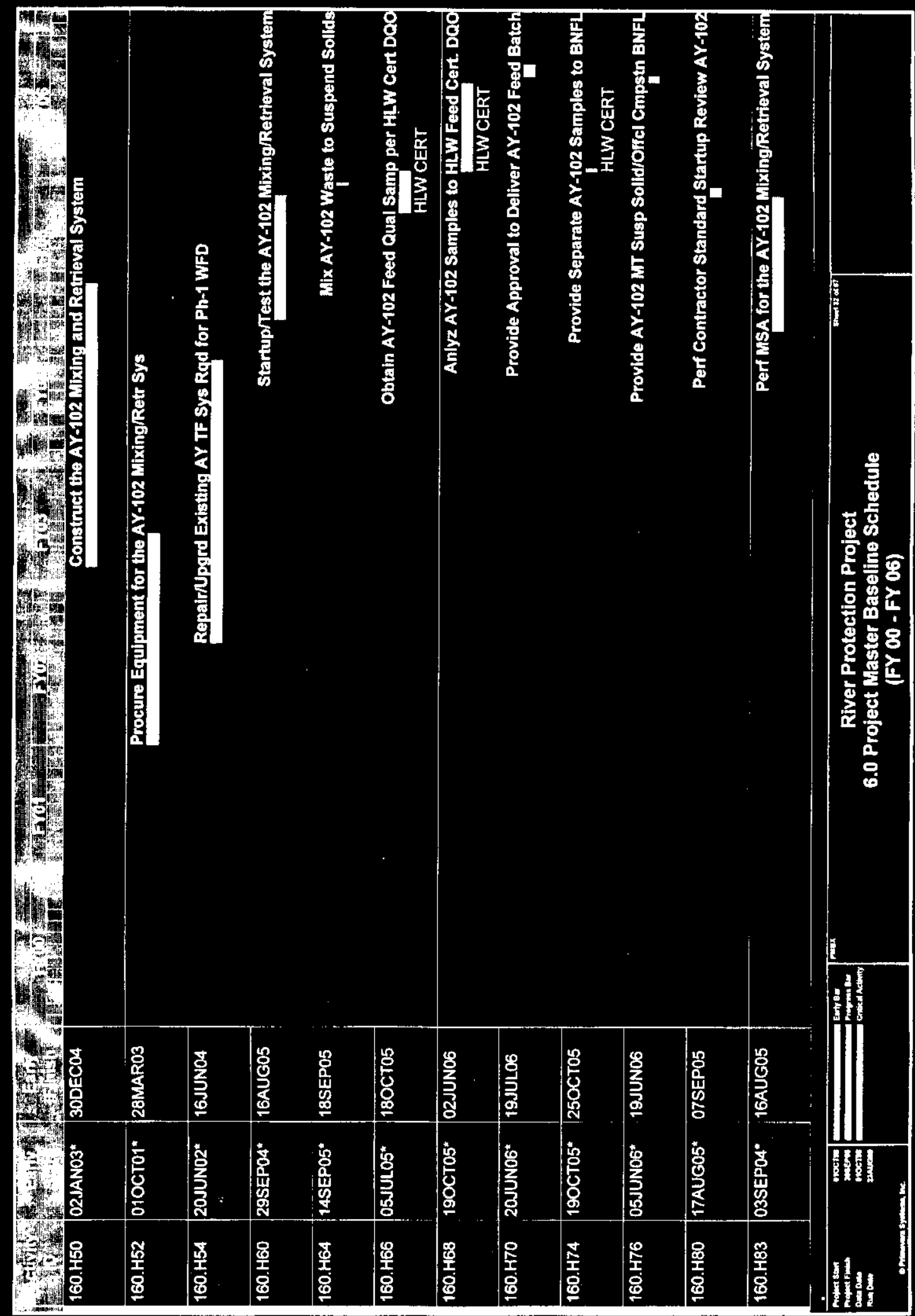




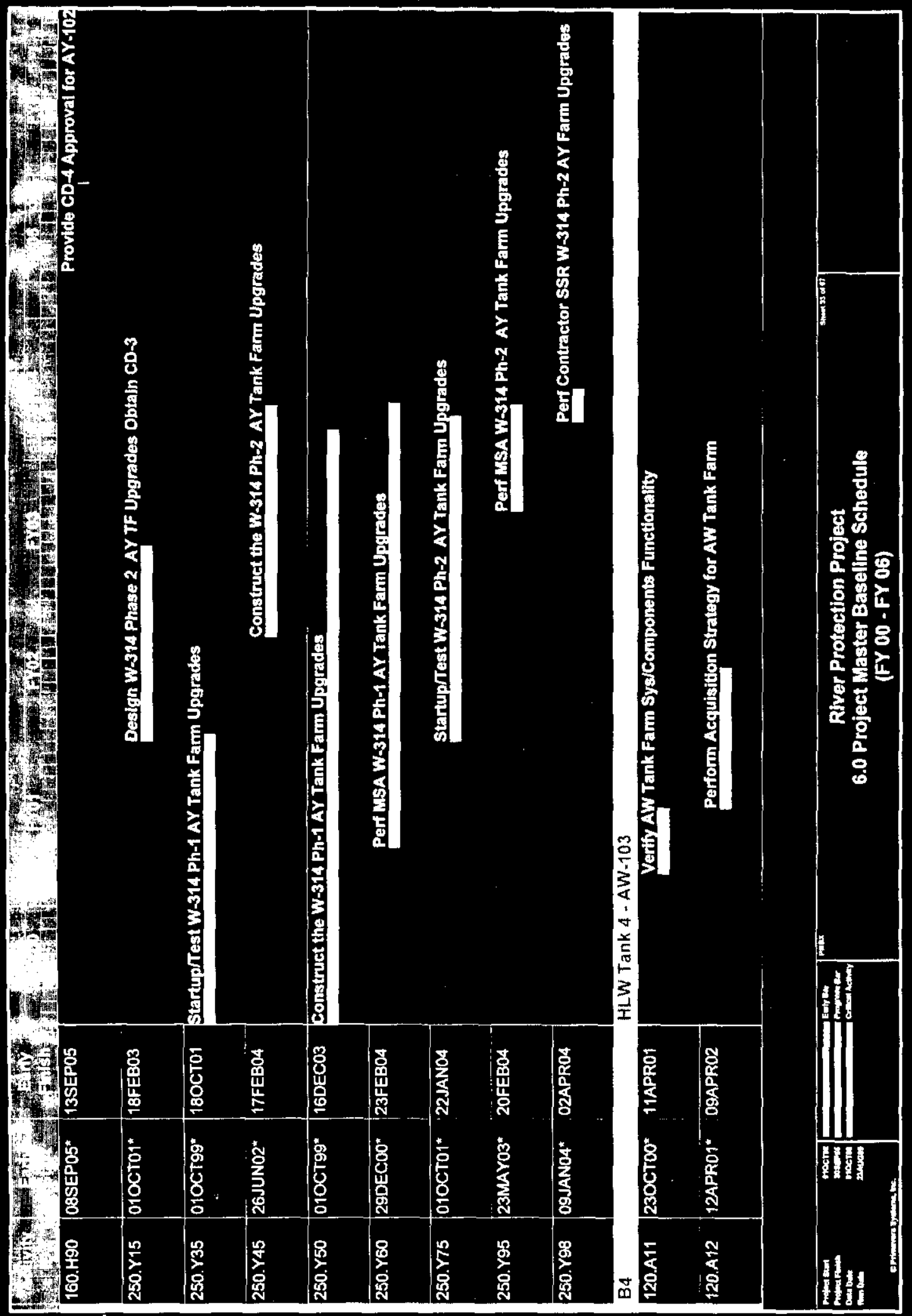




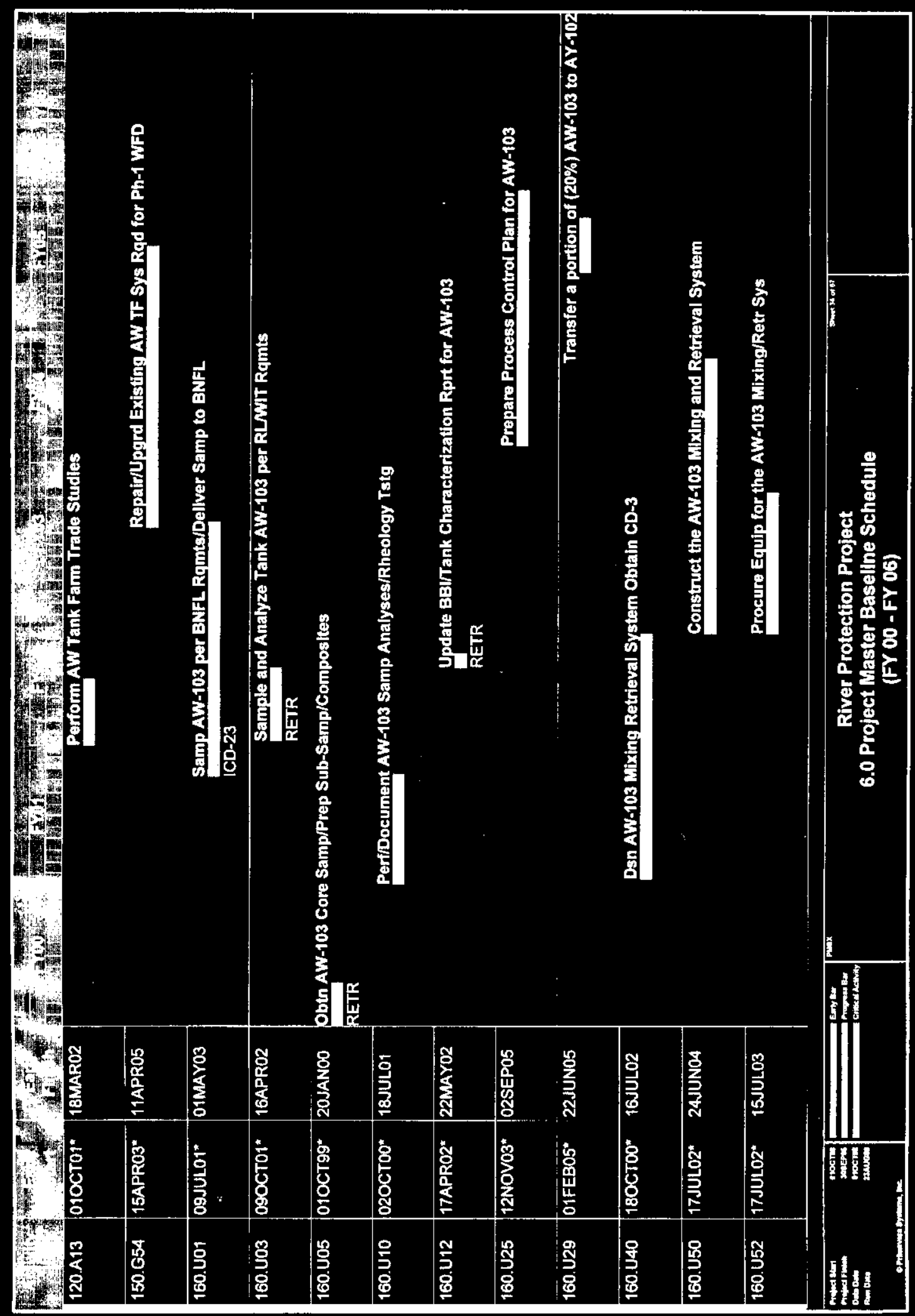


RPP-5044

6-36

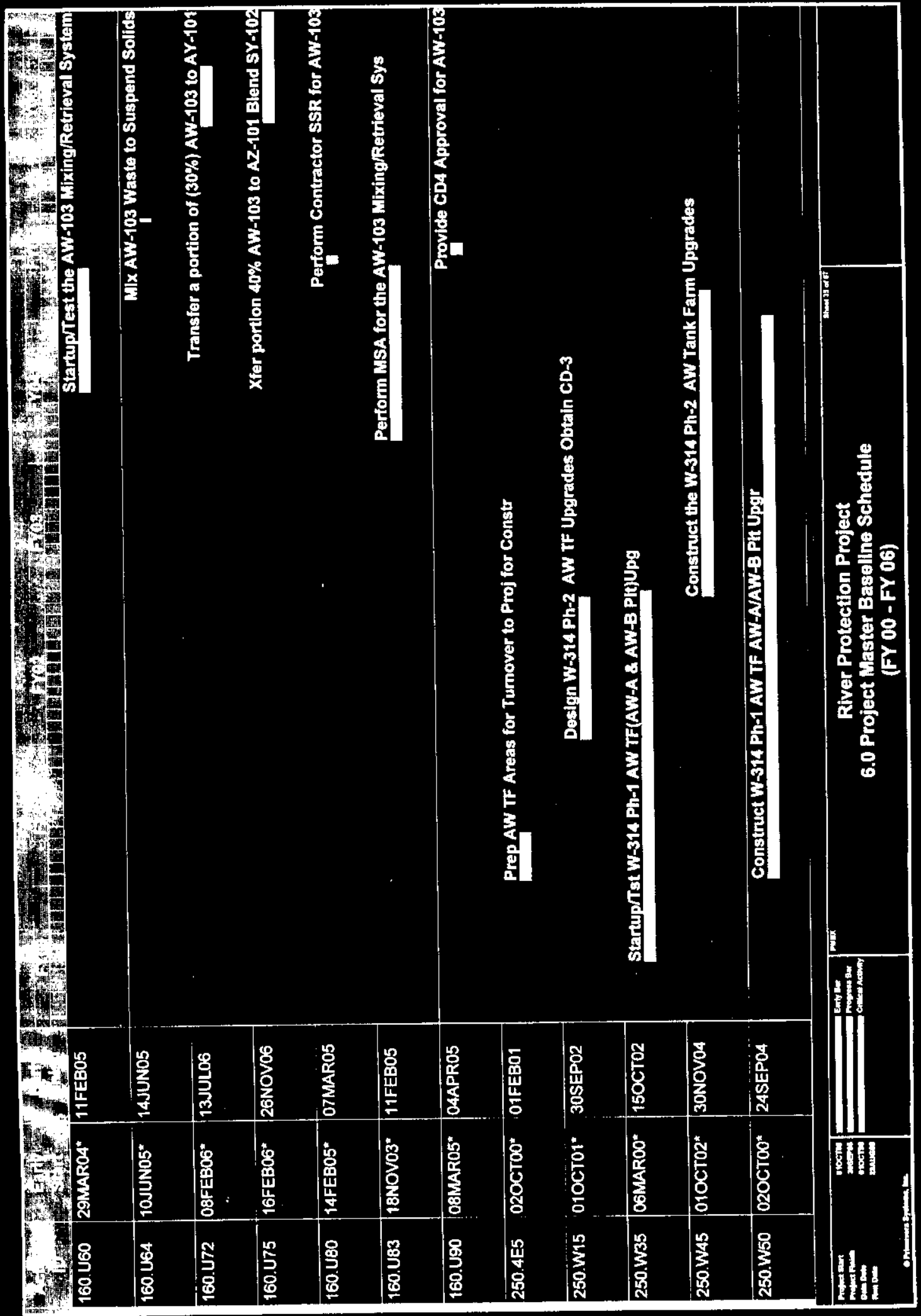




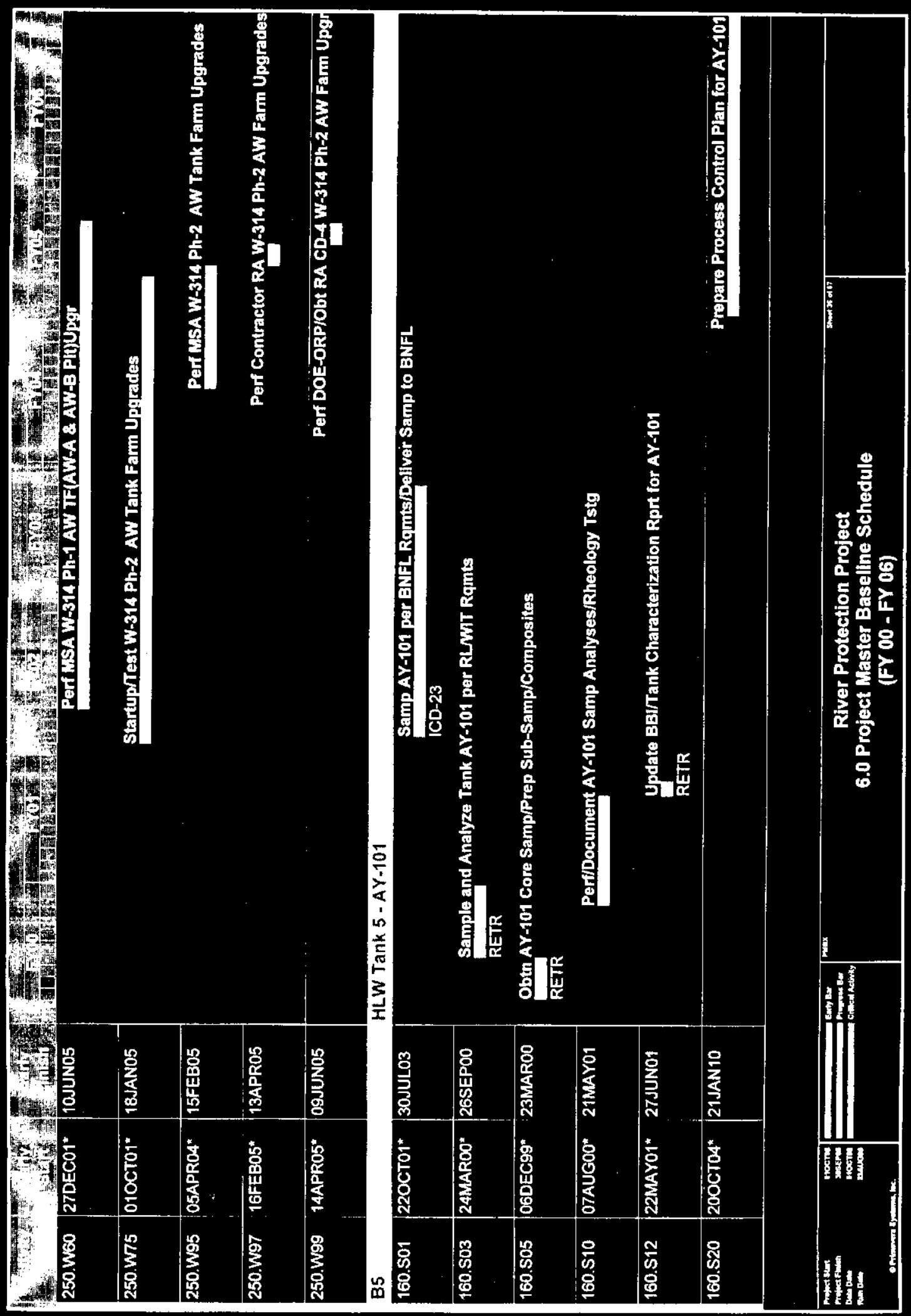


RPP-5044

6-38

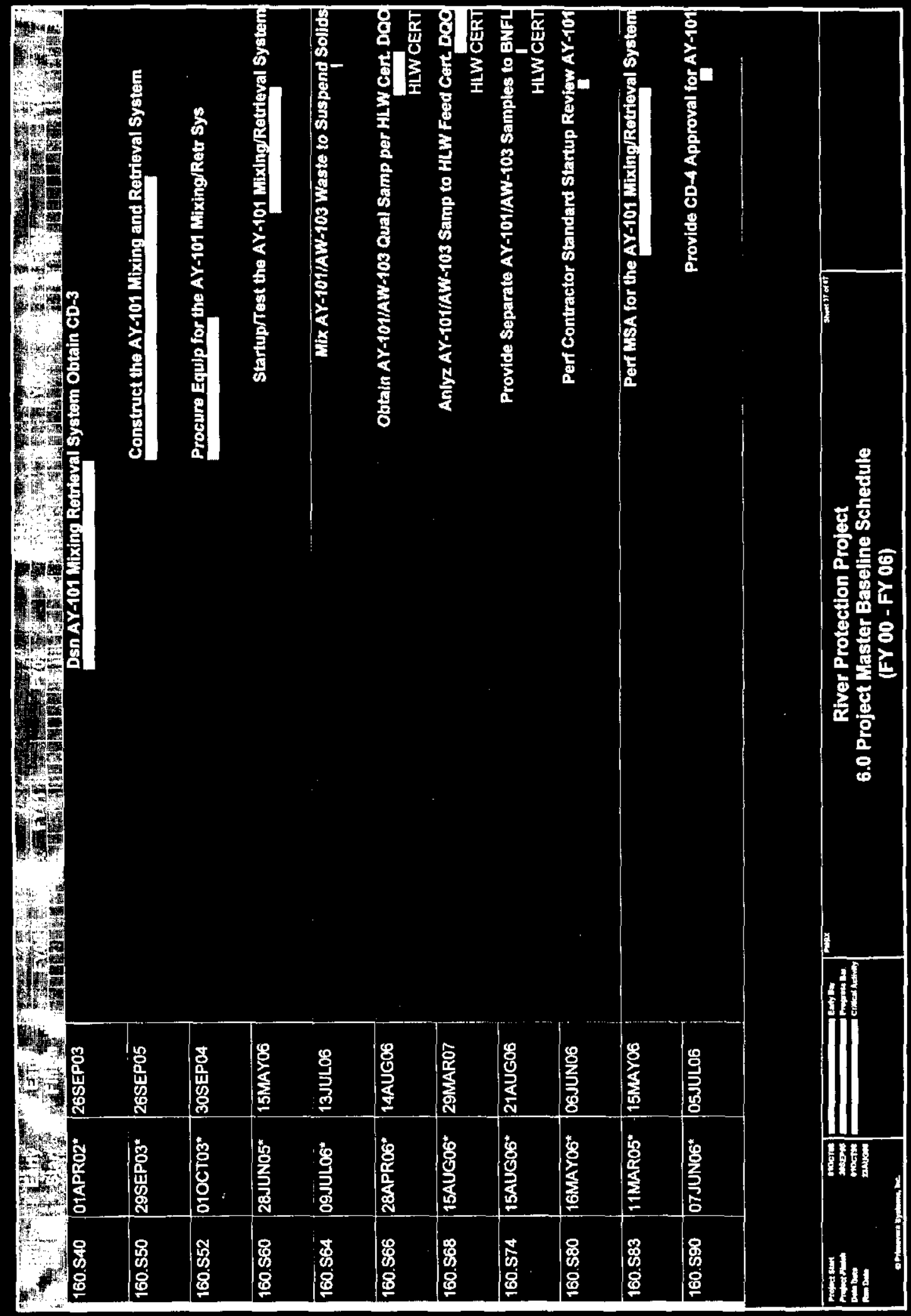




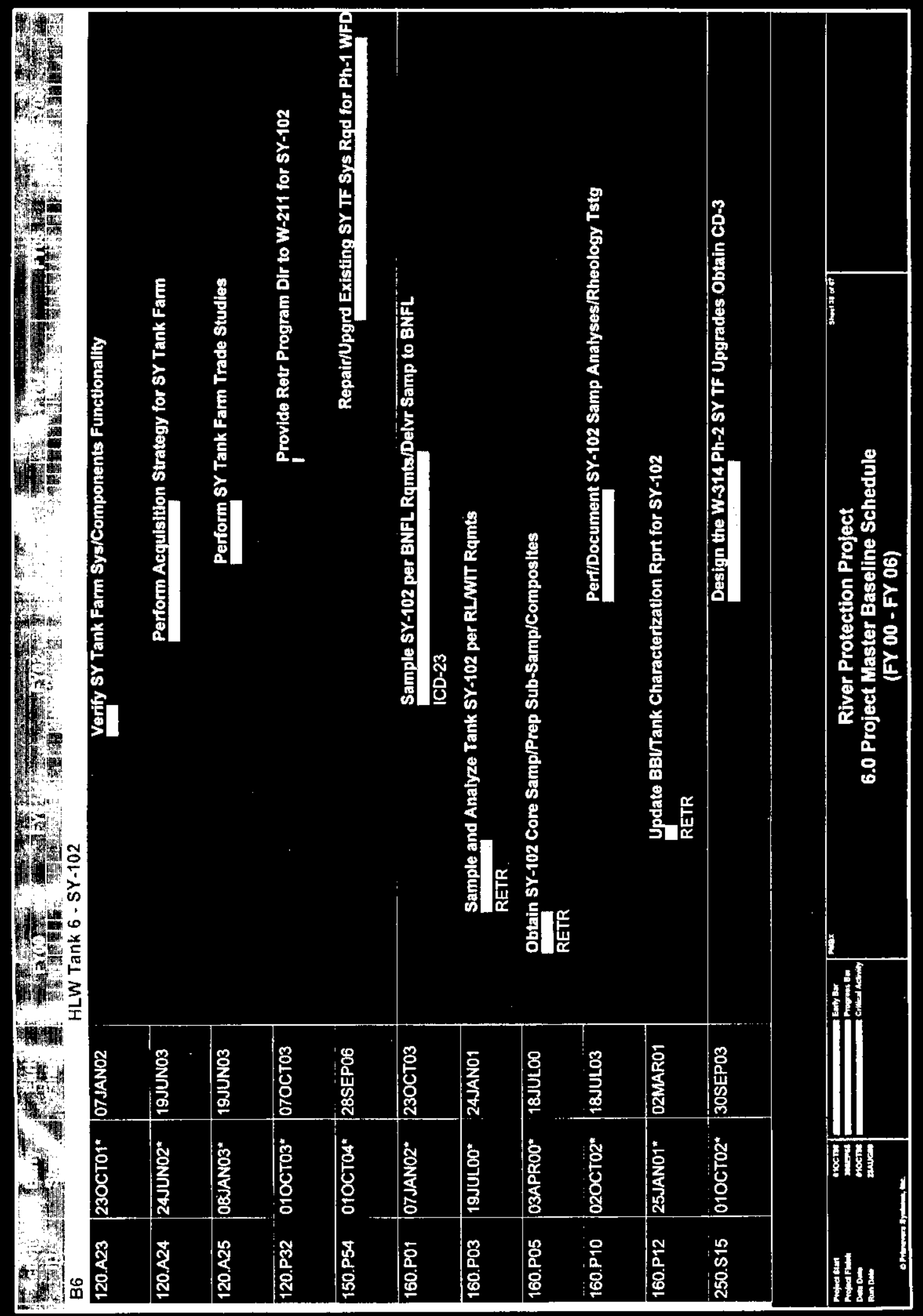


RPP-5044

6-40

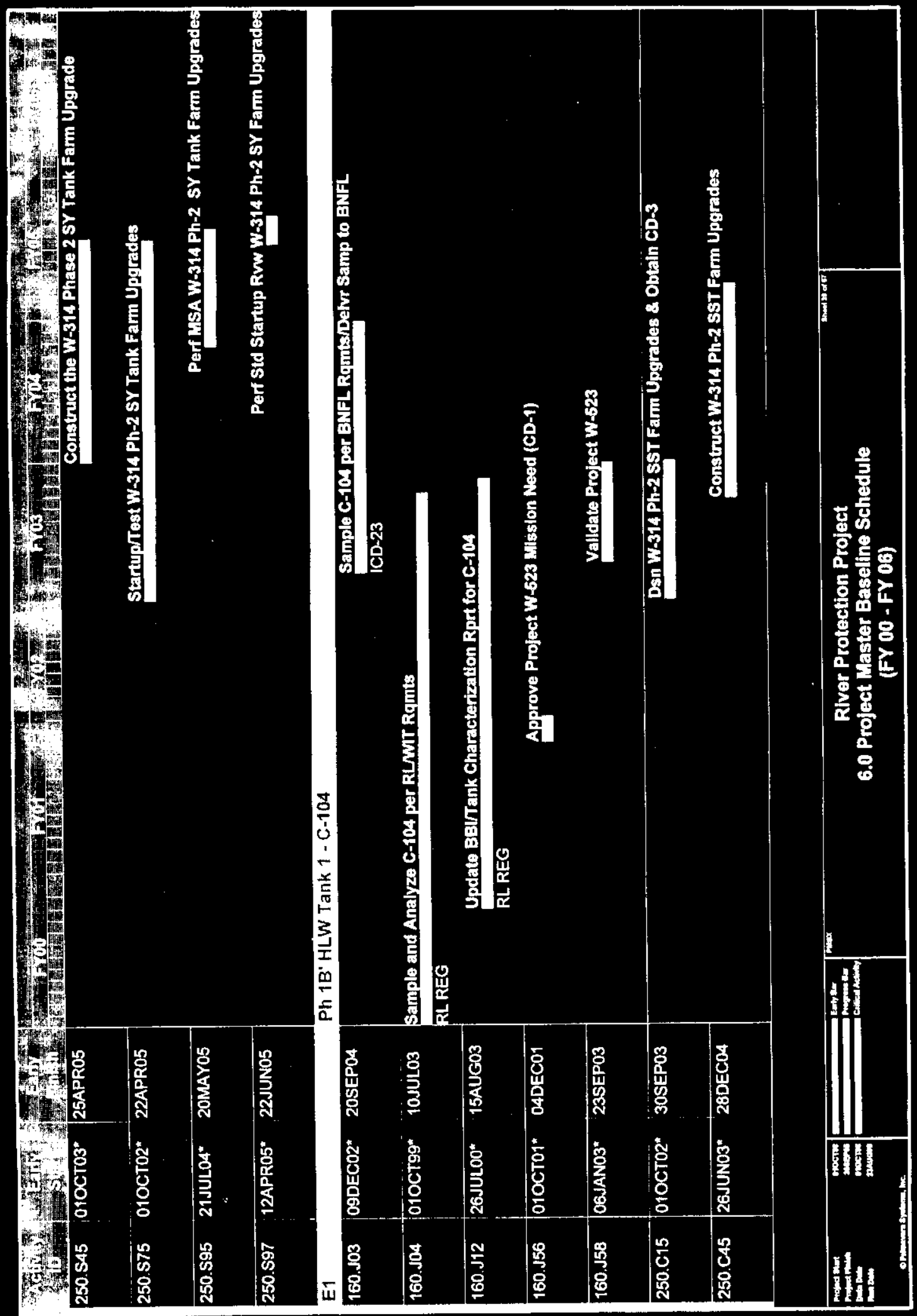




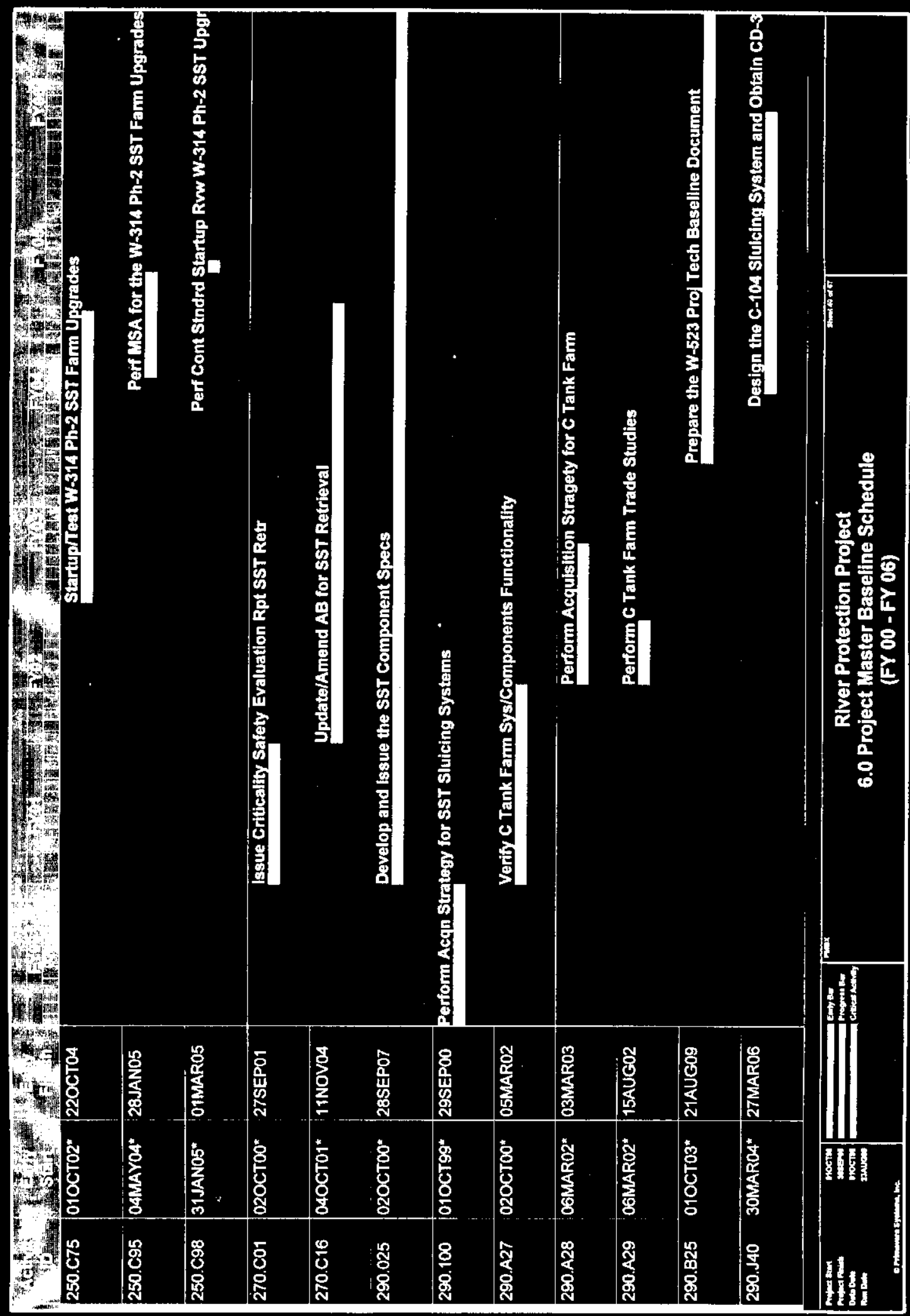


RPP-5044

6-42

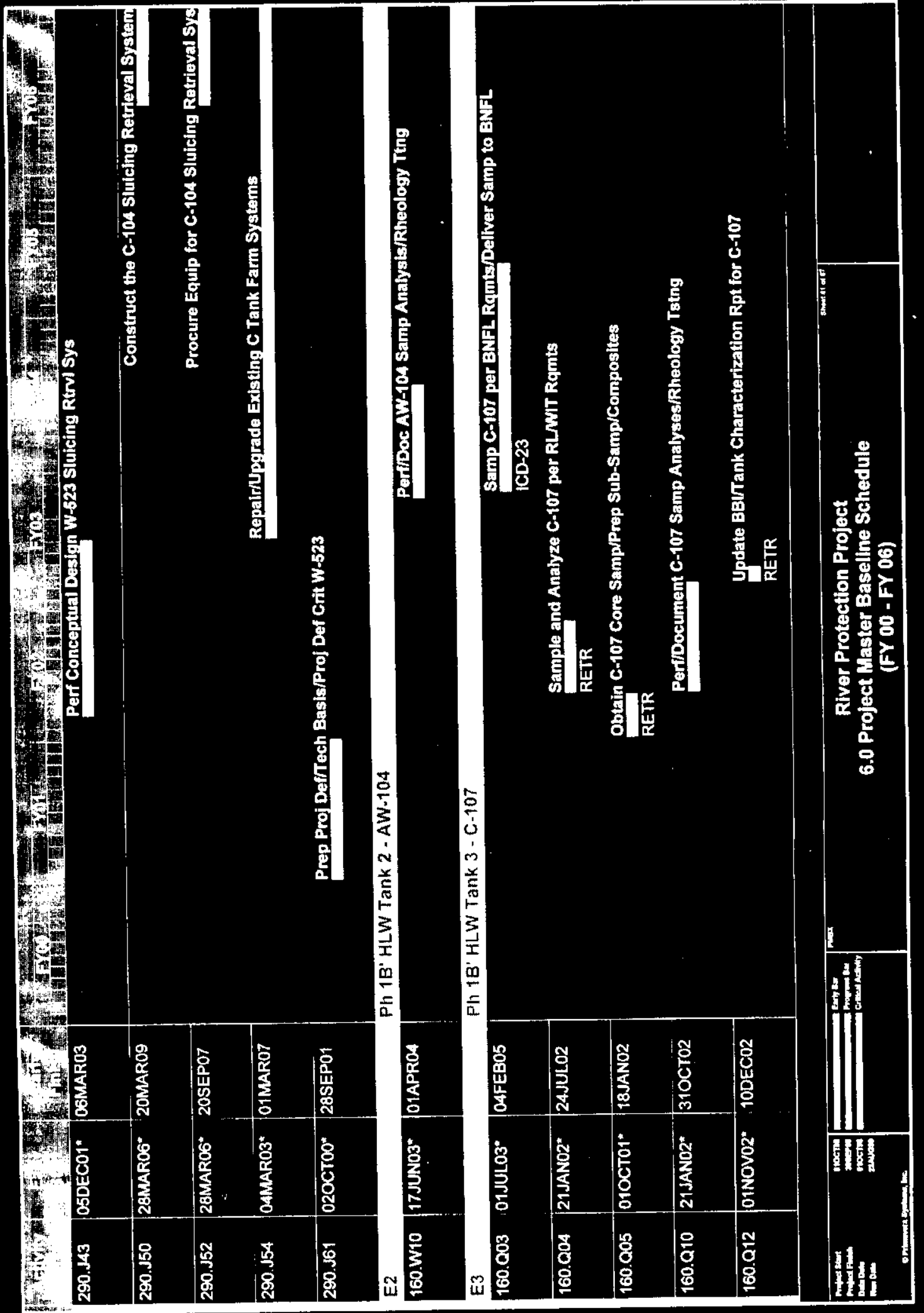




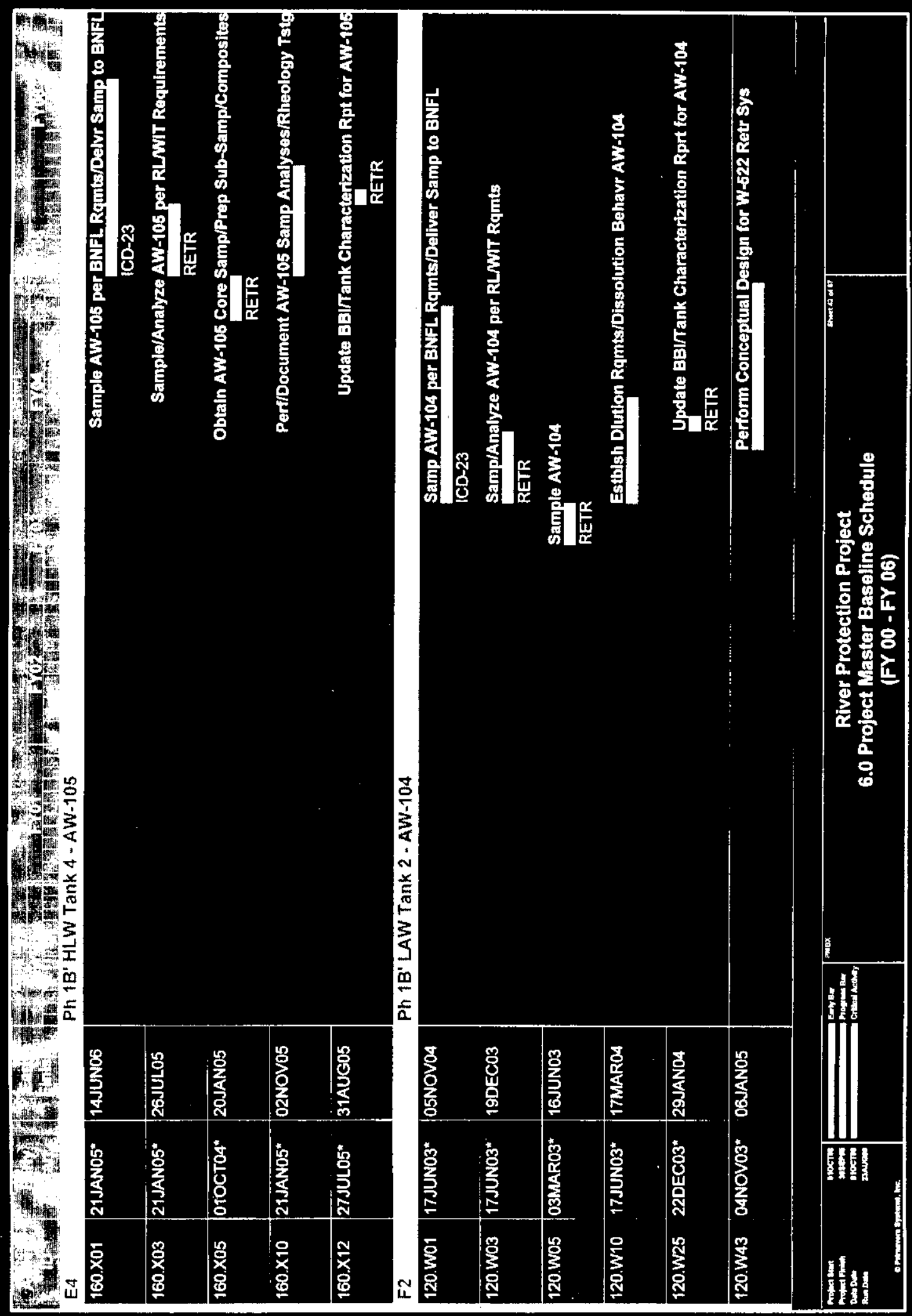


RPP-5044

6-44

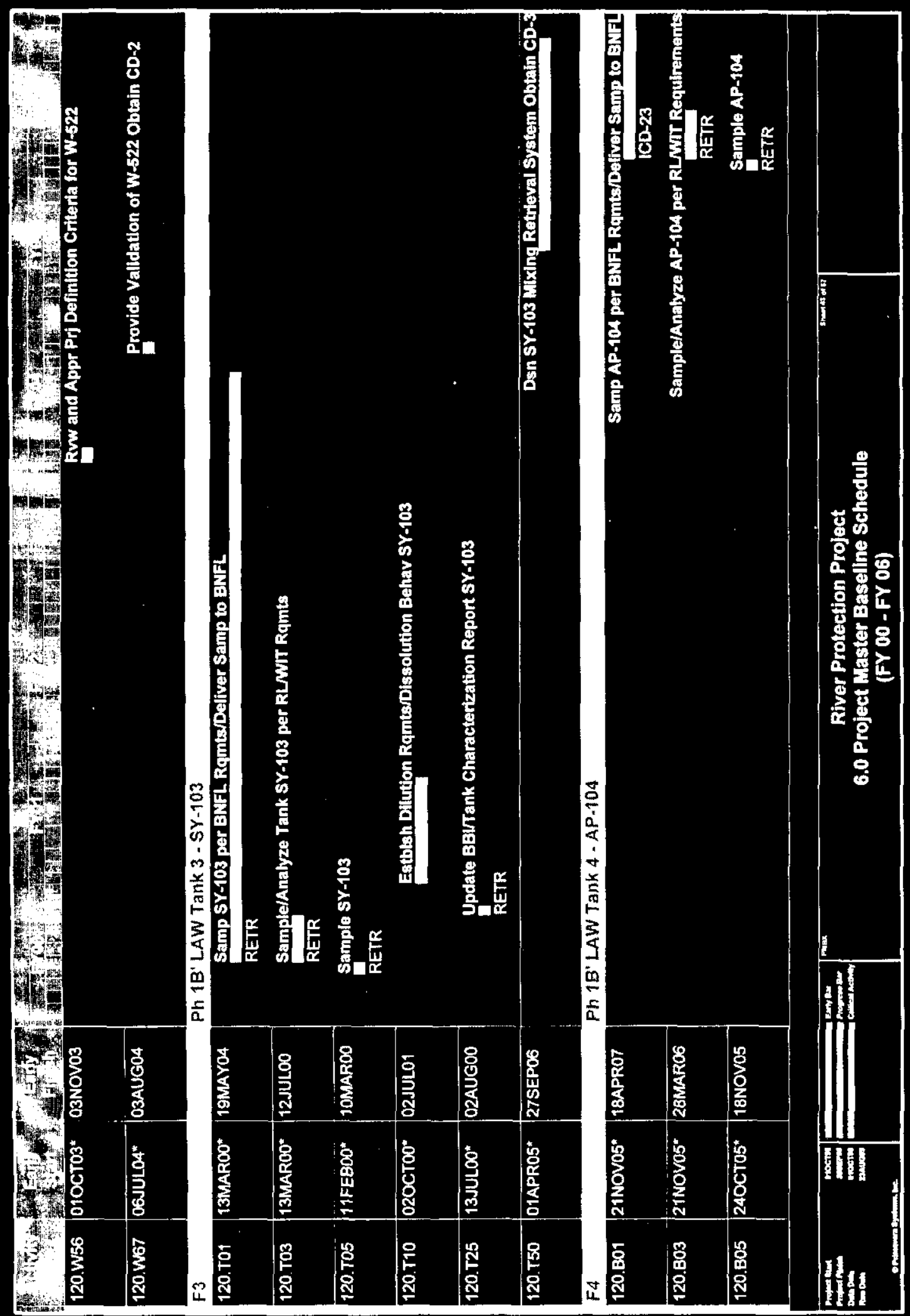




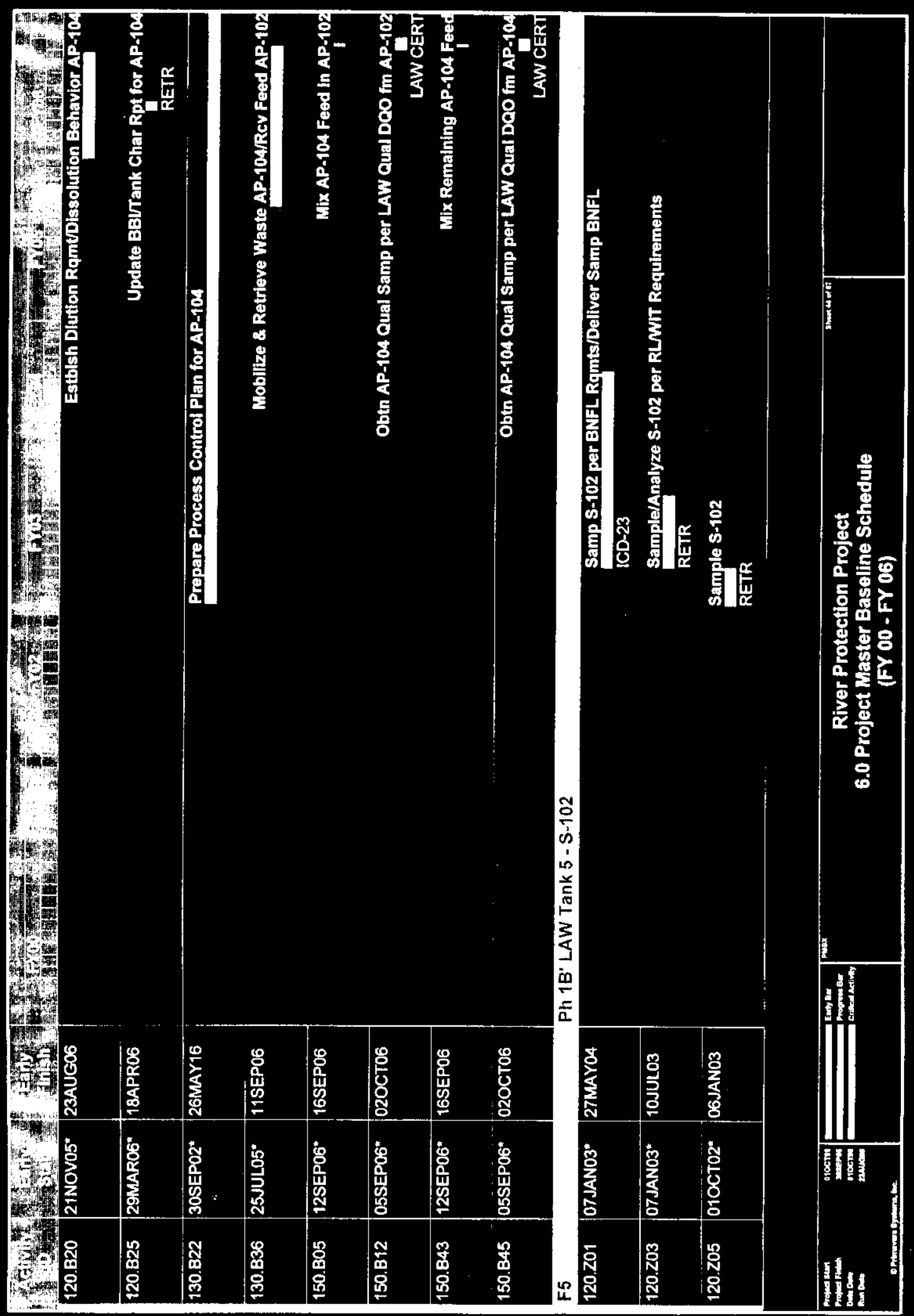




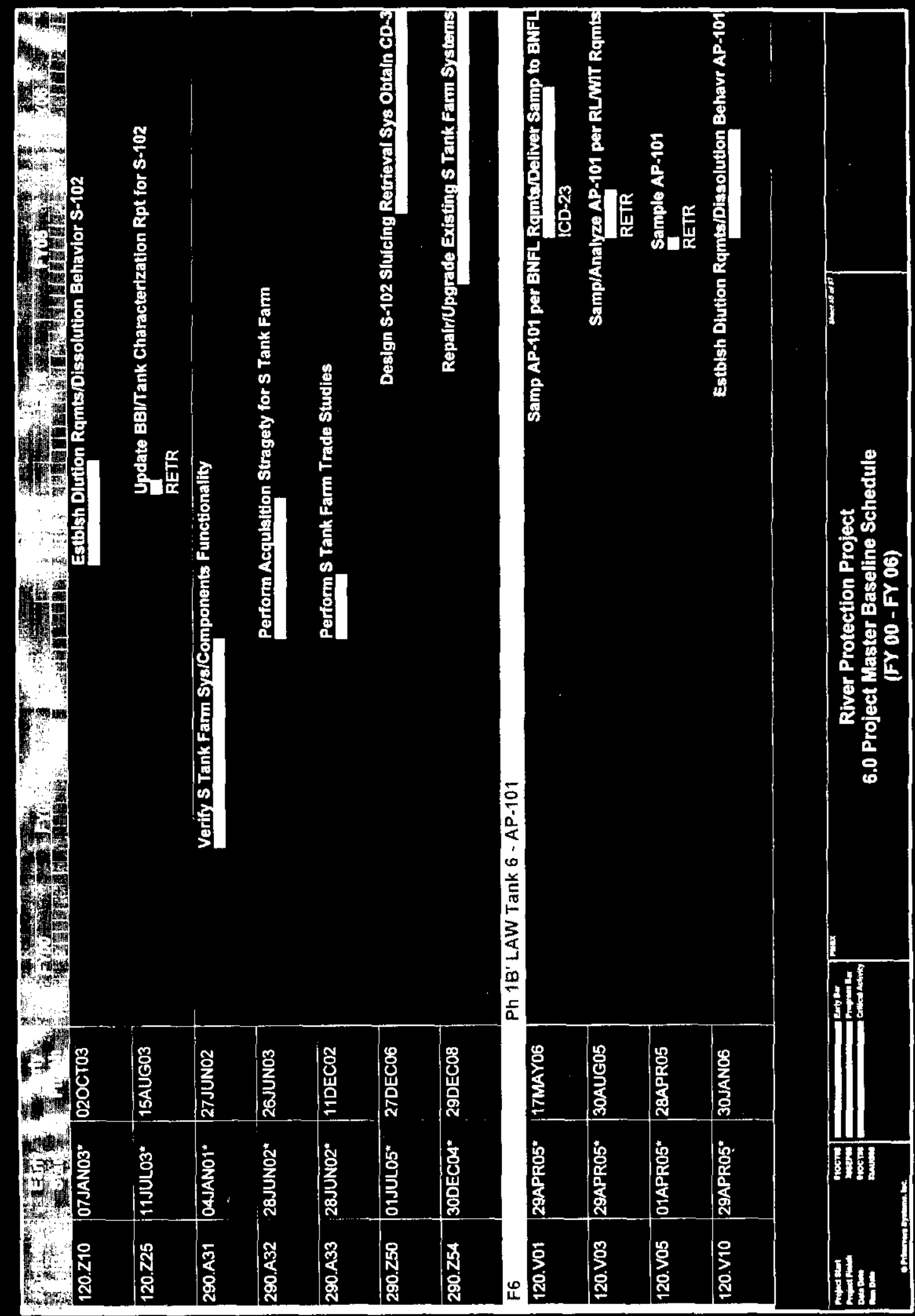




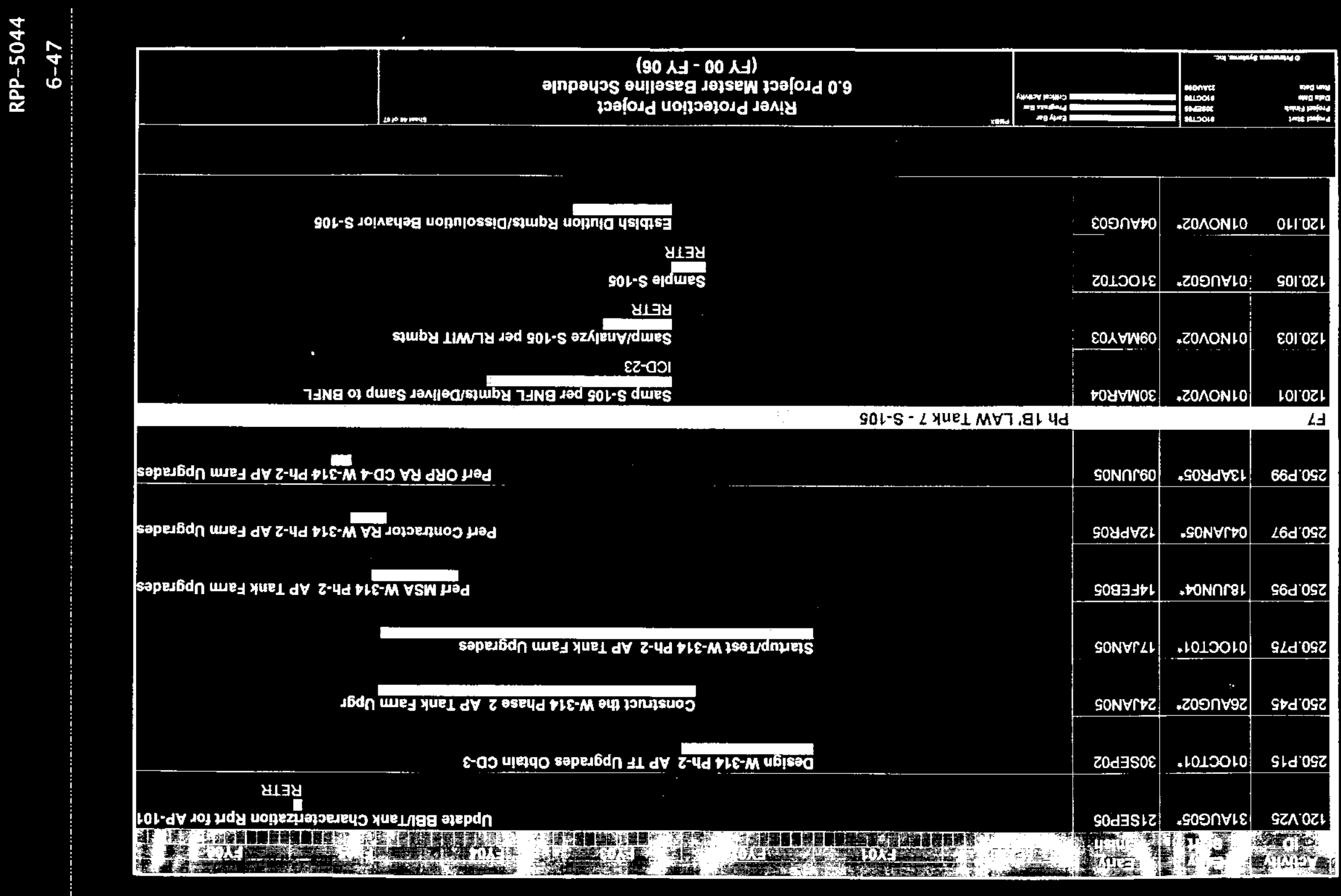


RPP-5044

6-48

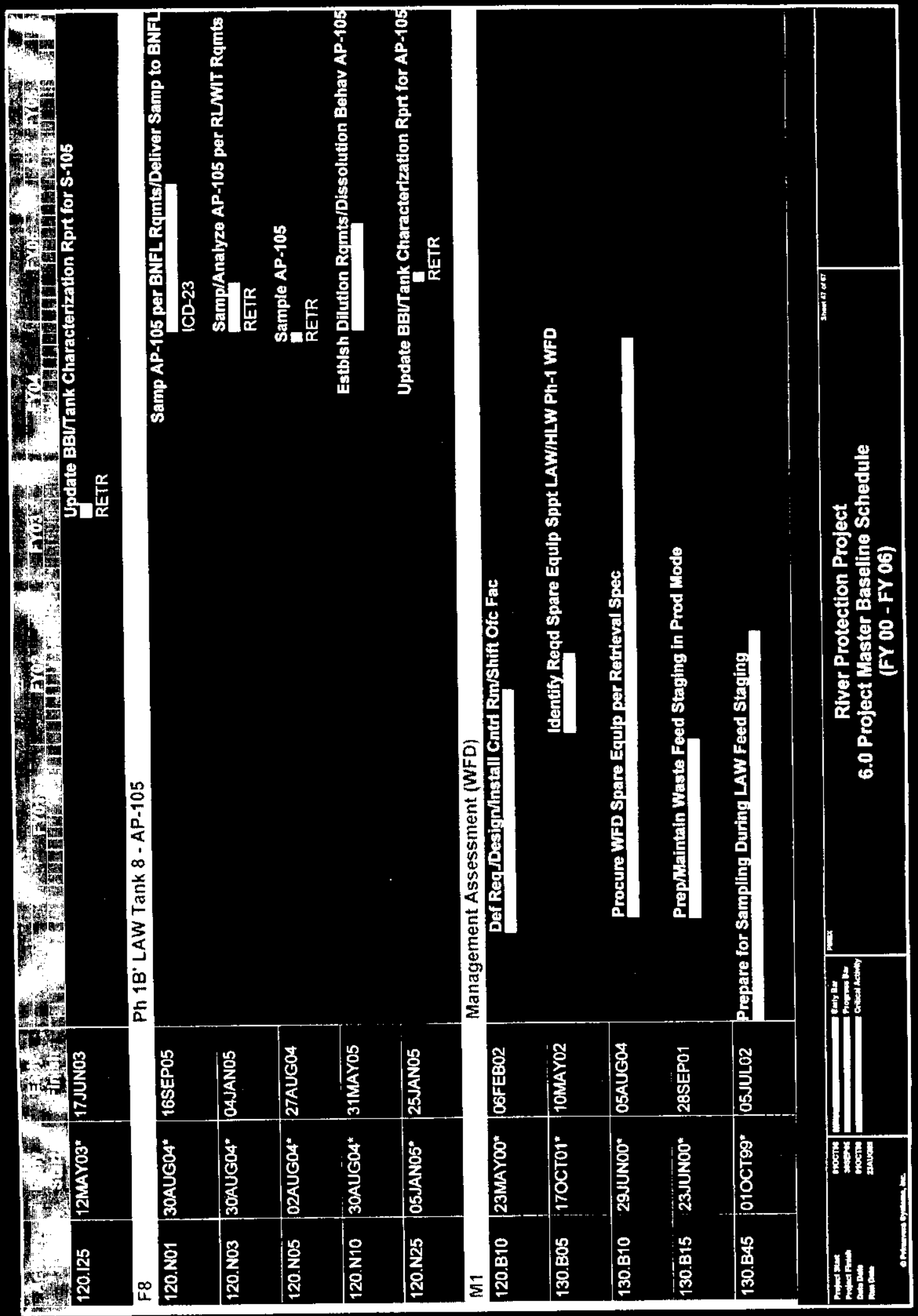




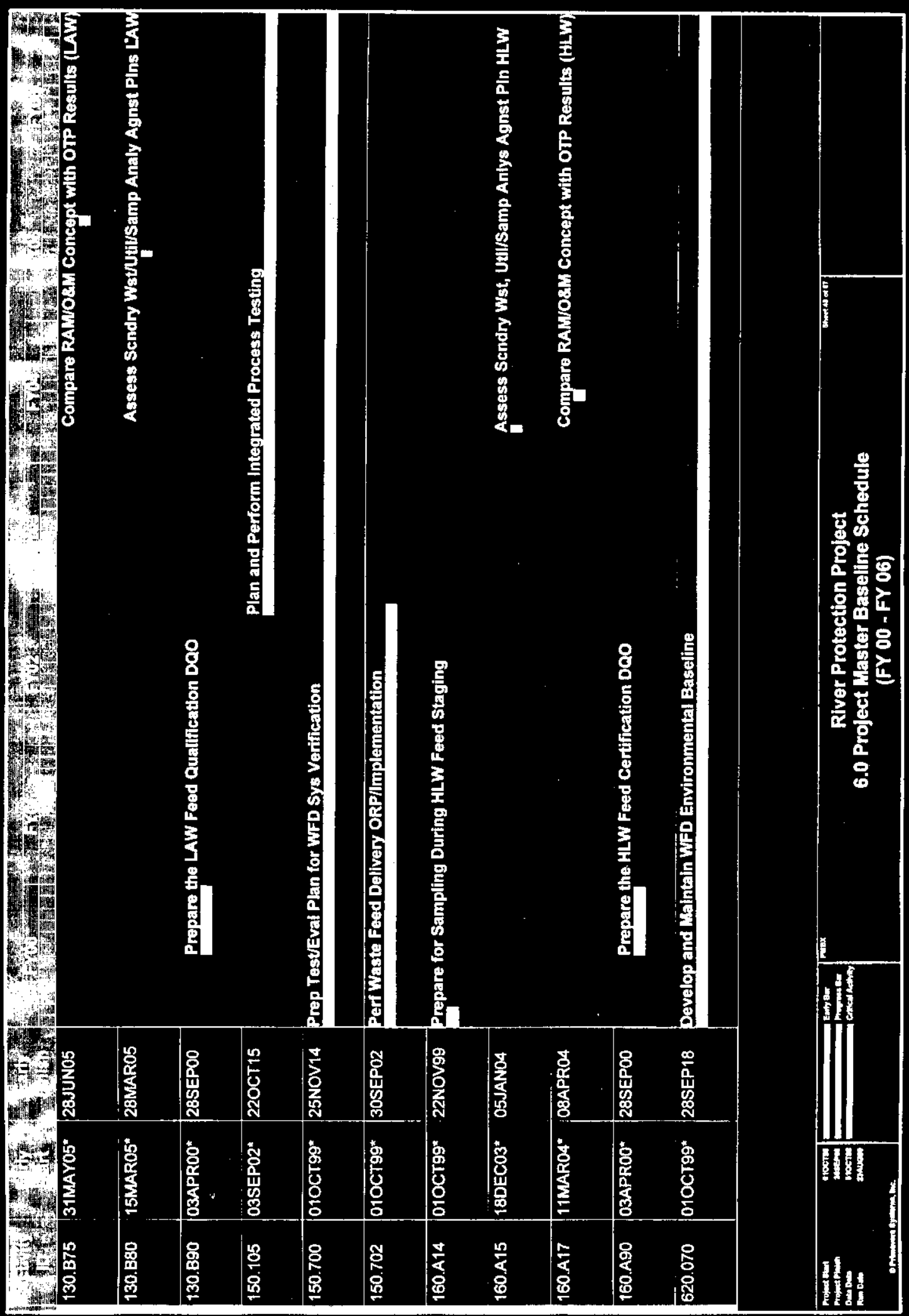


RPP-5044

6-50

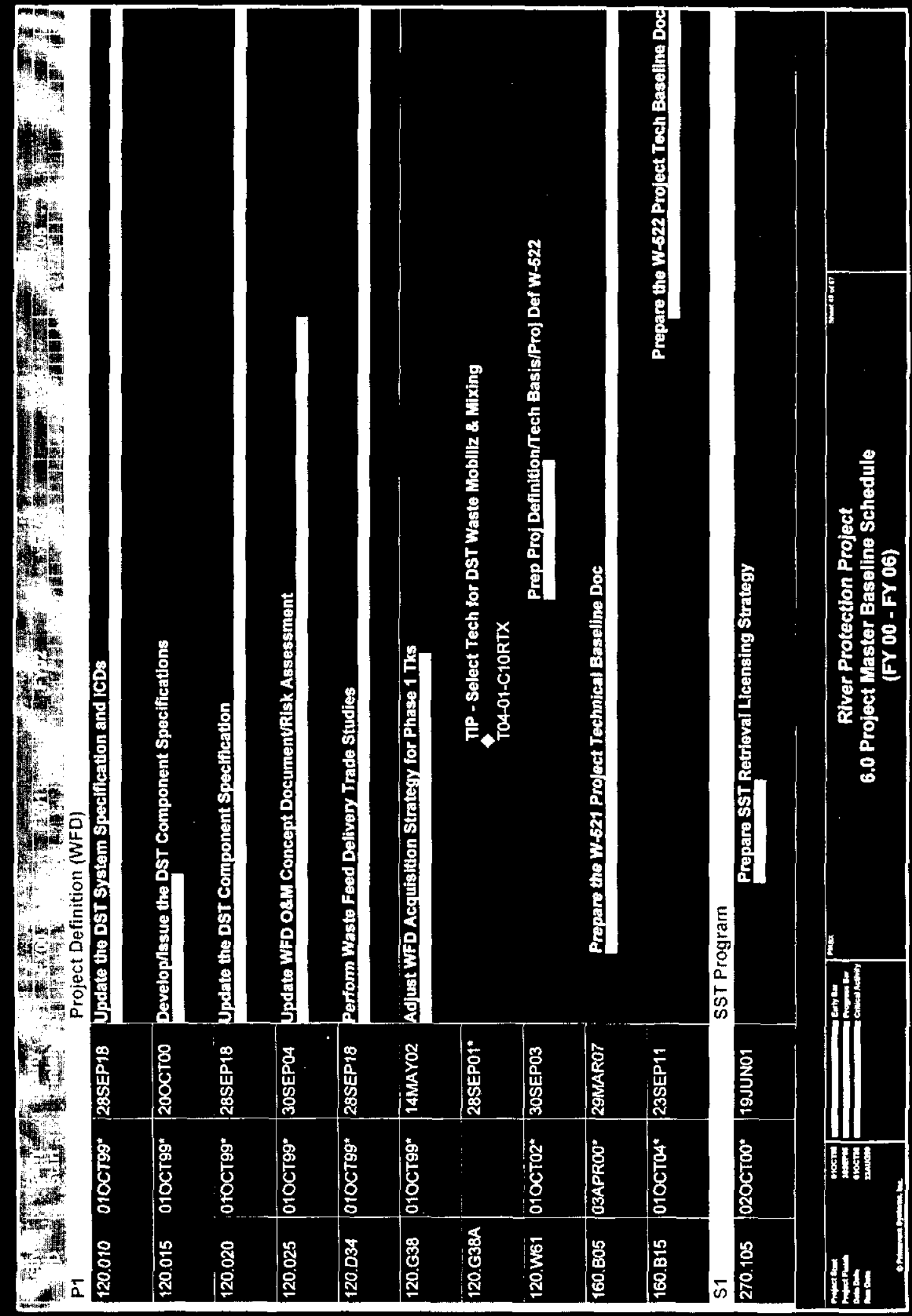




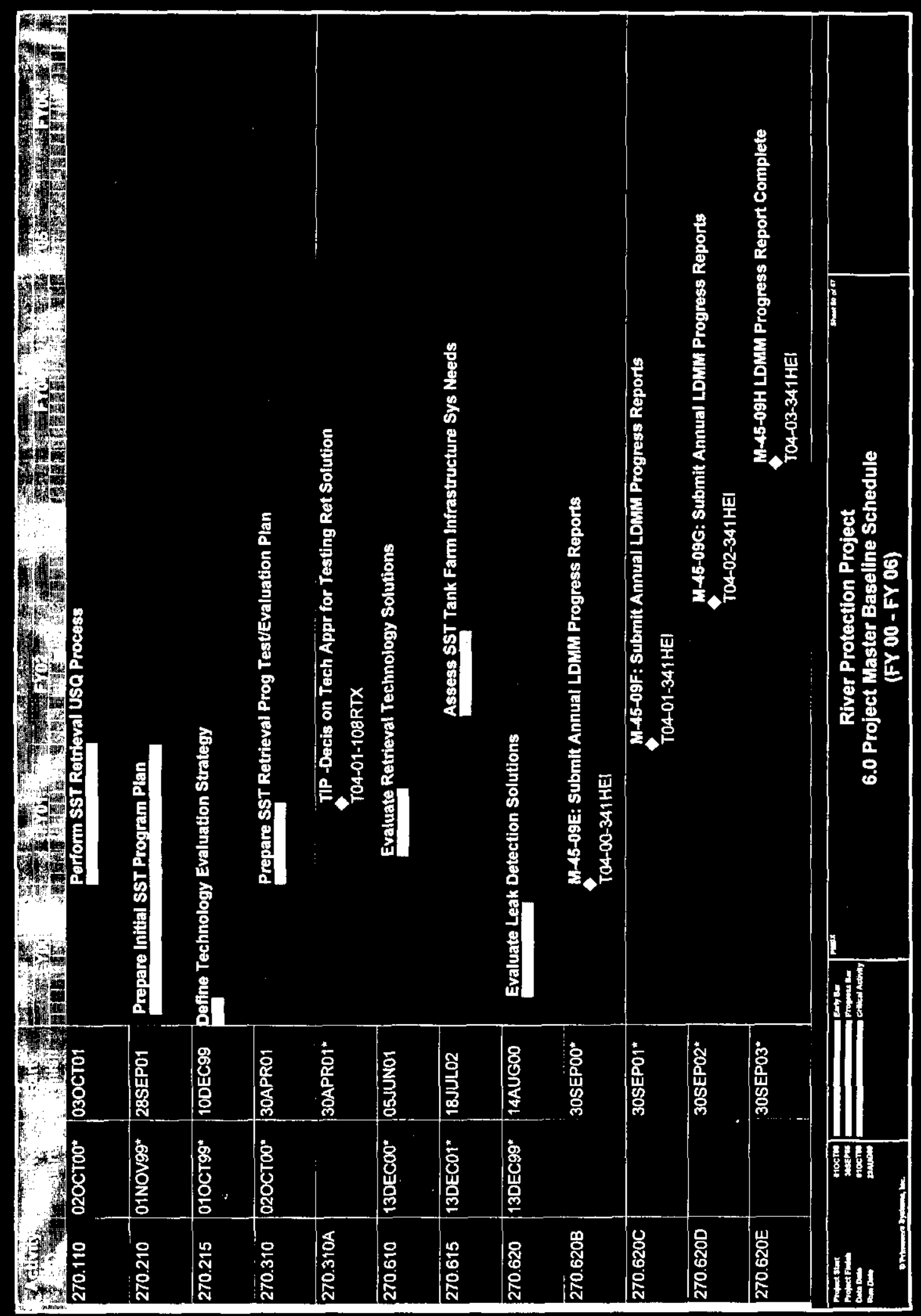


RPP-5044

6-52

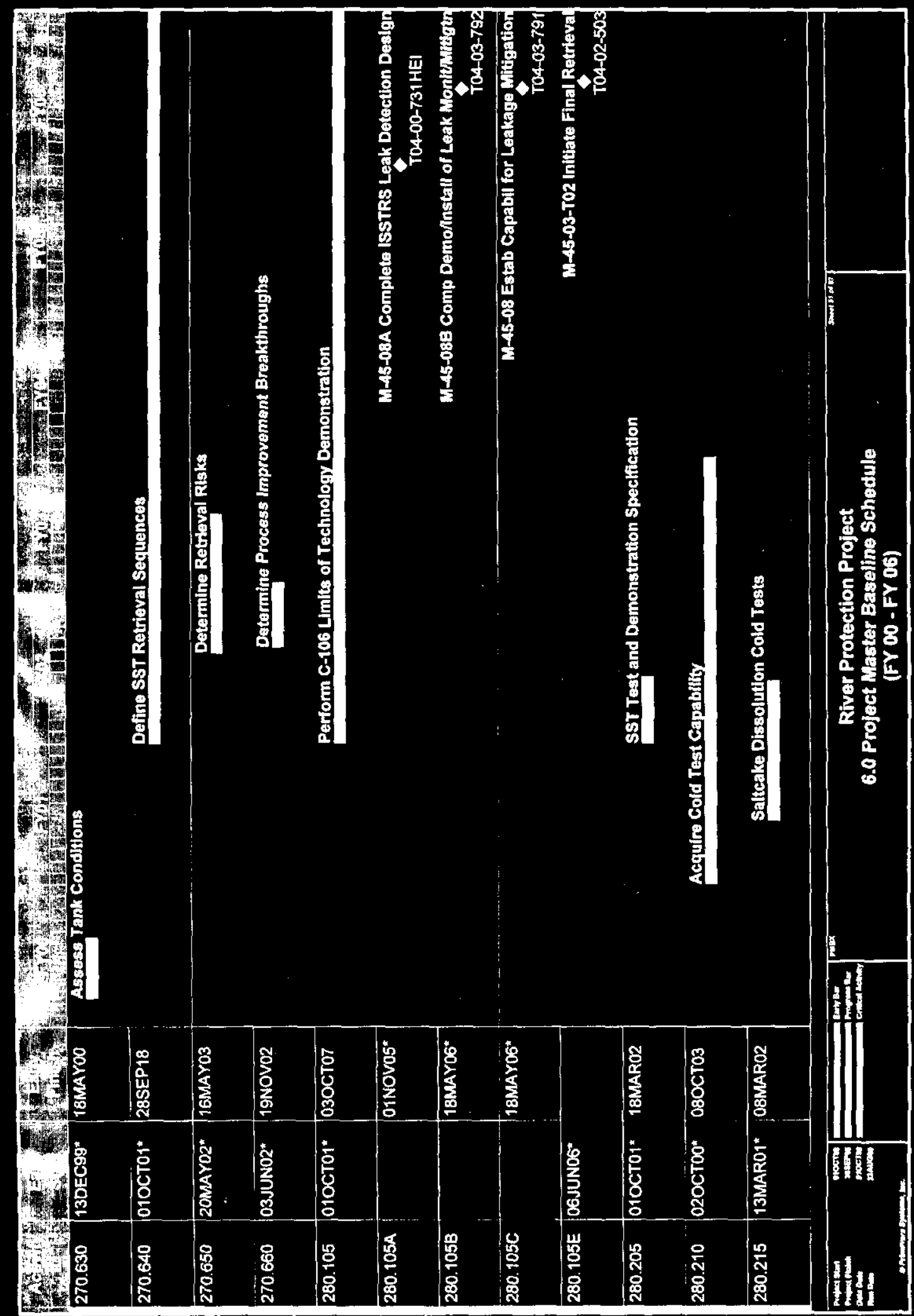




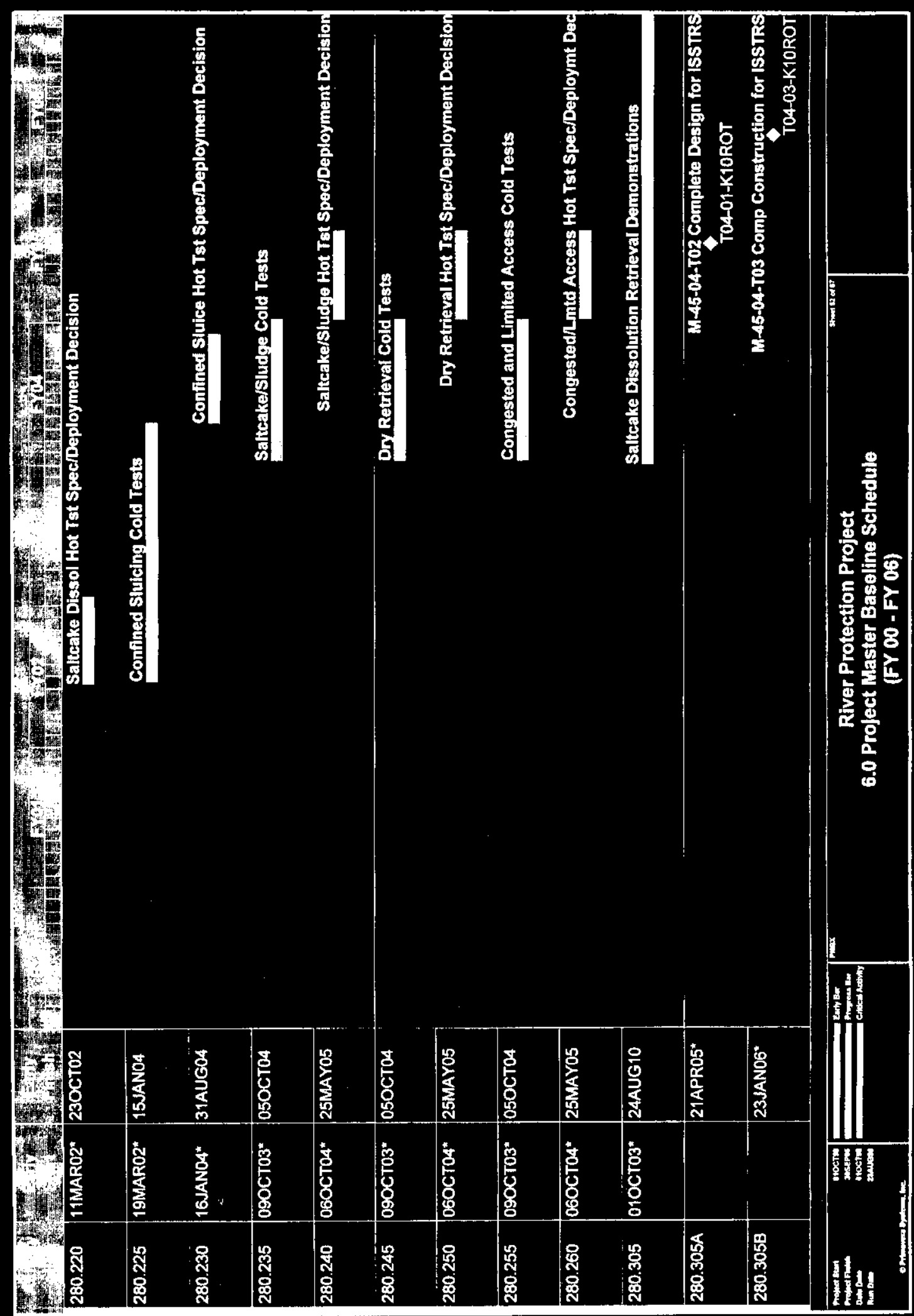




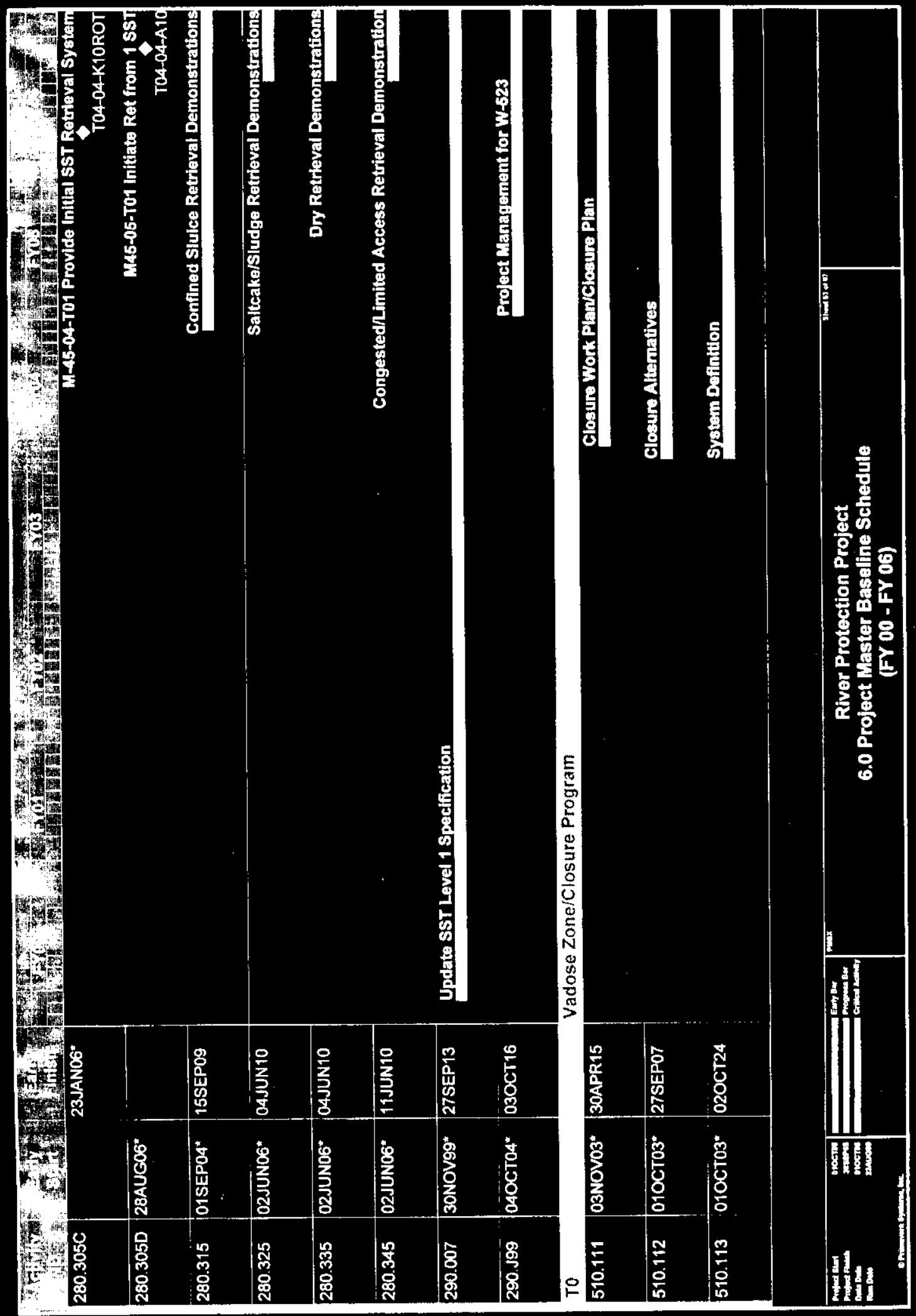




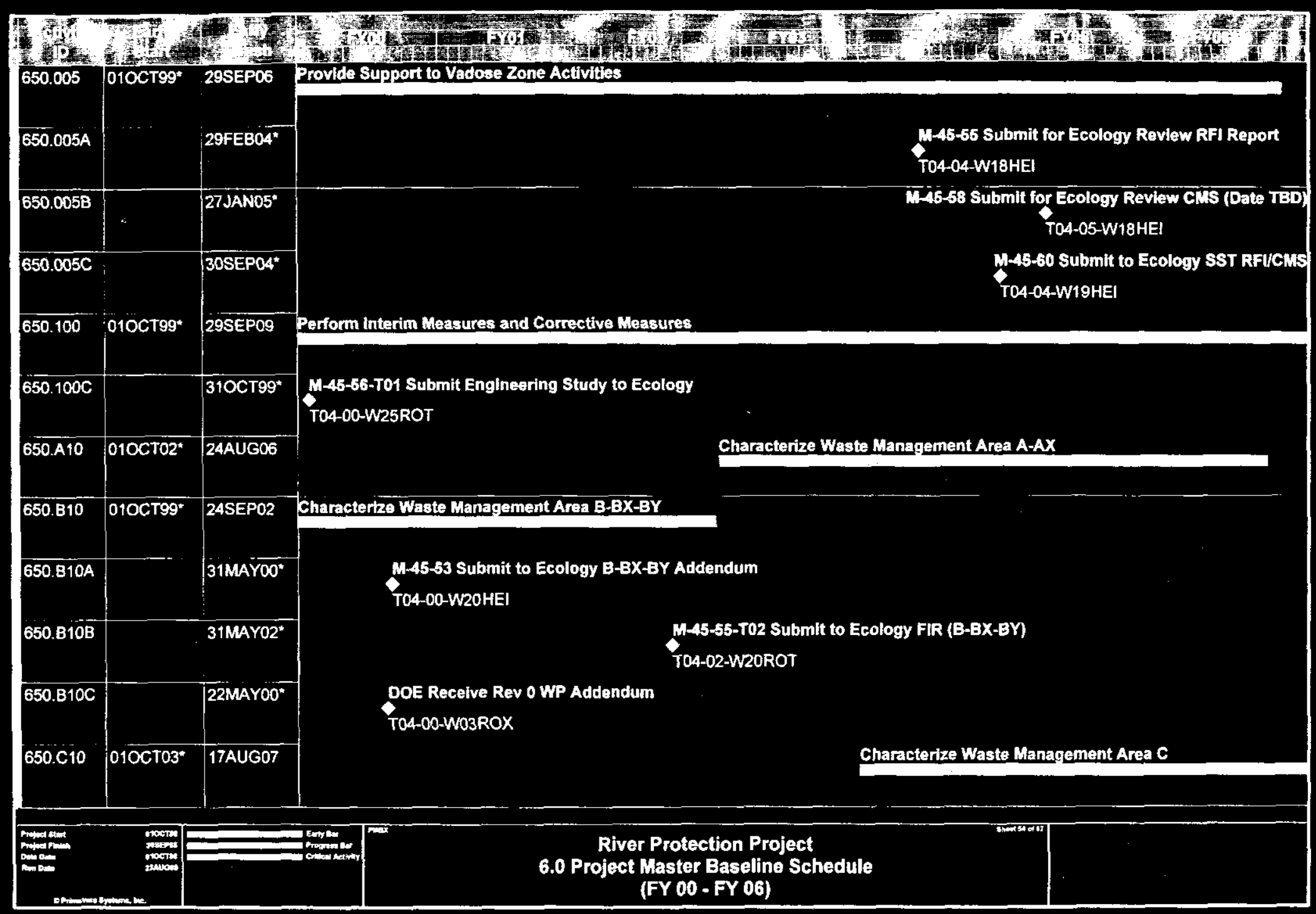

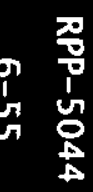




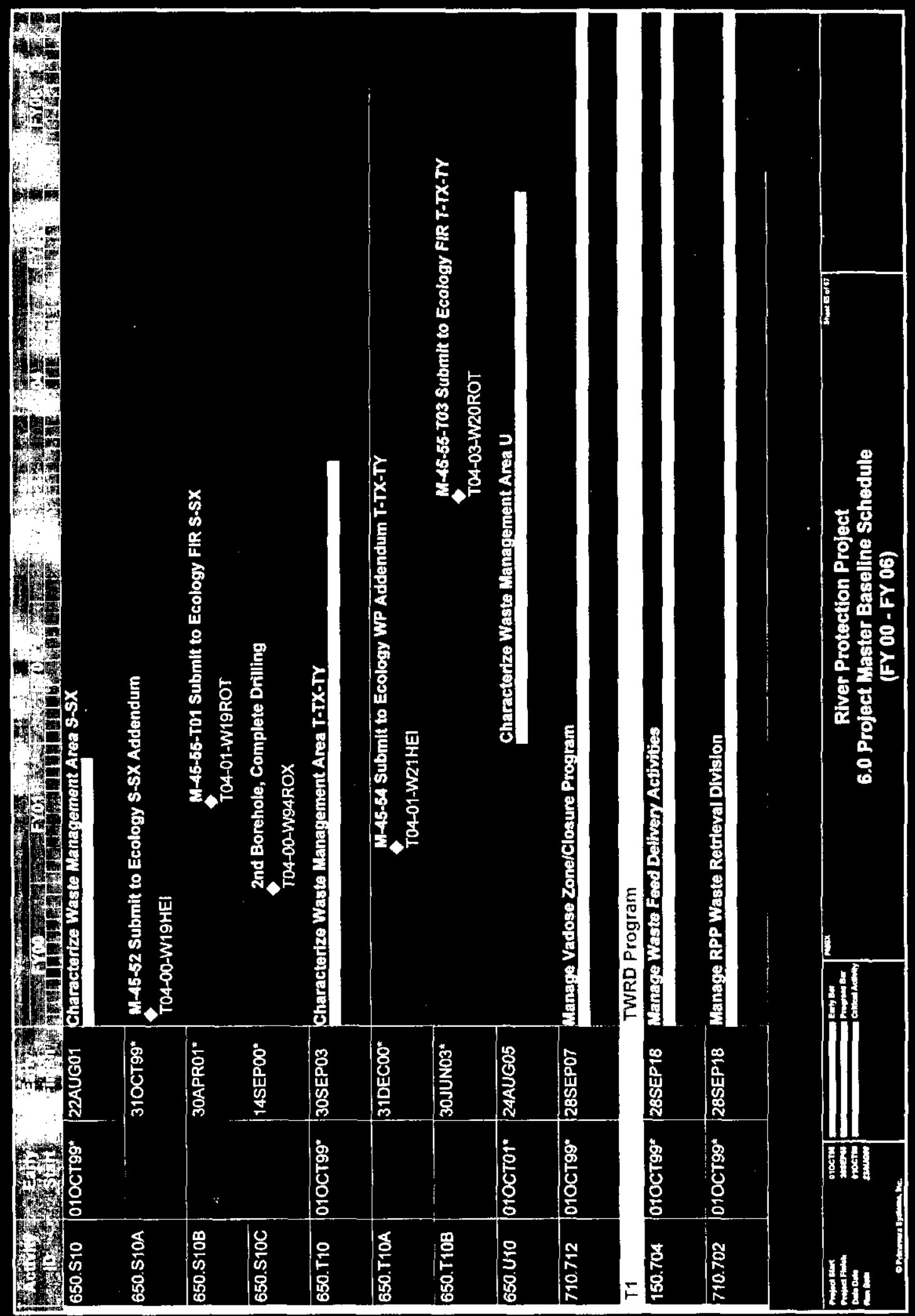




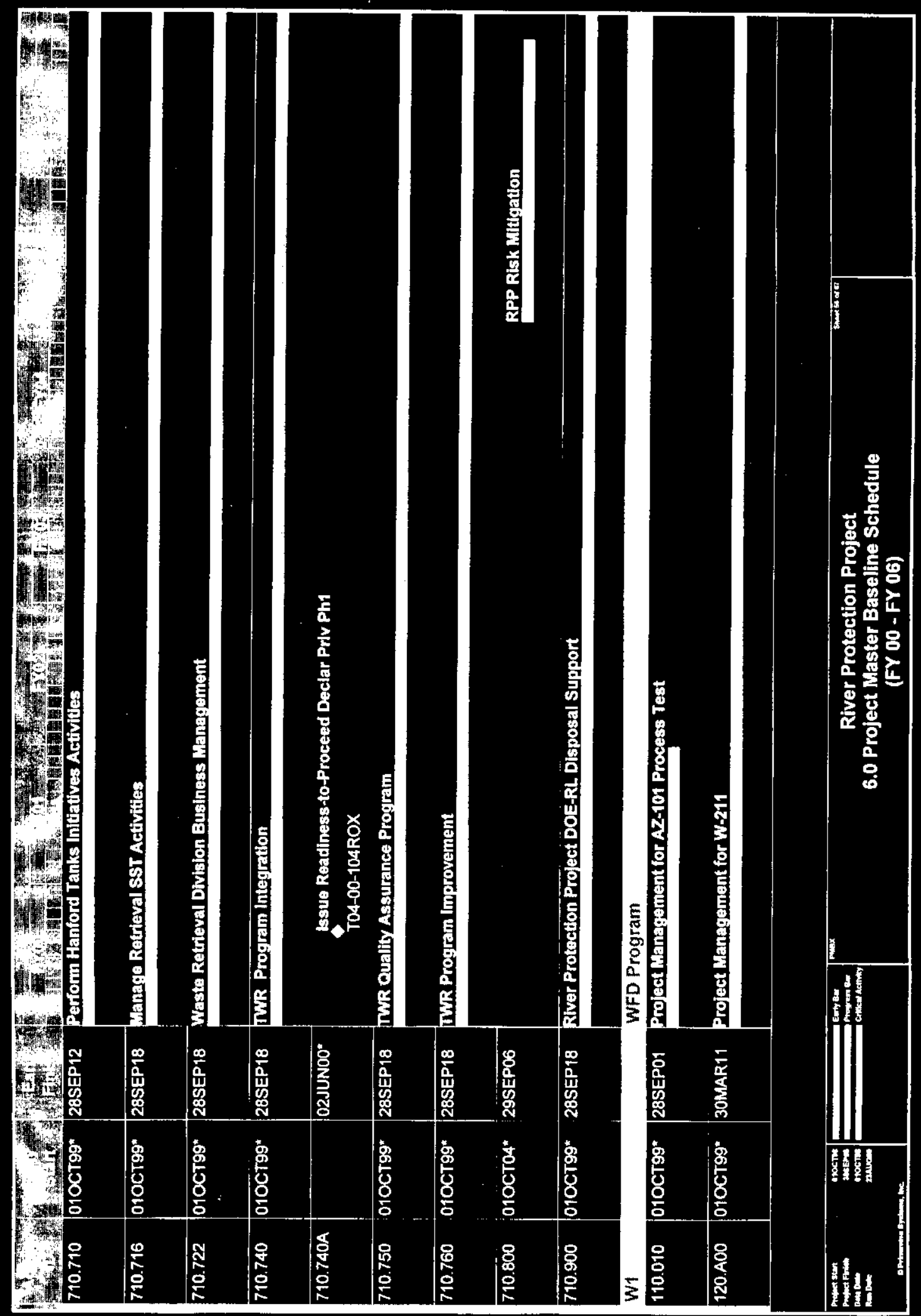




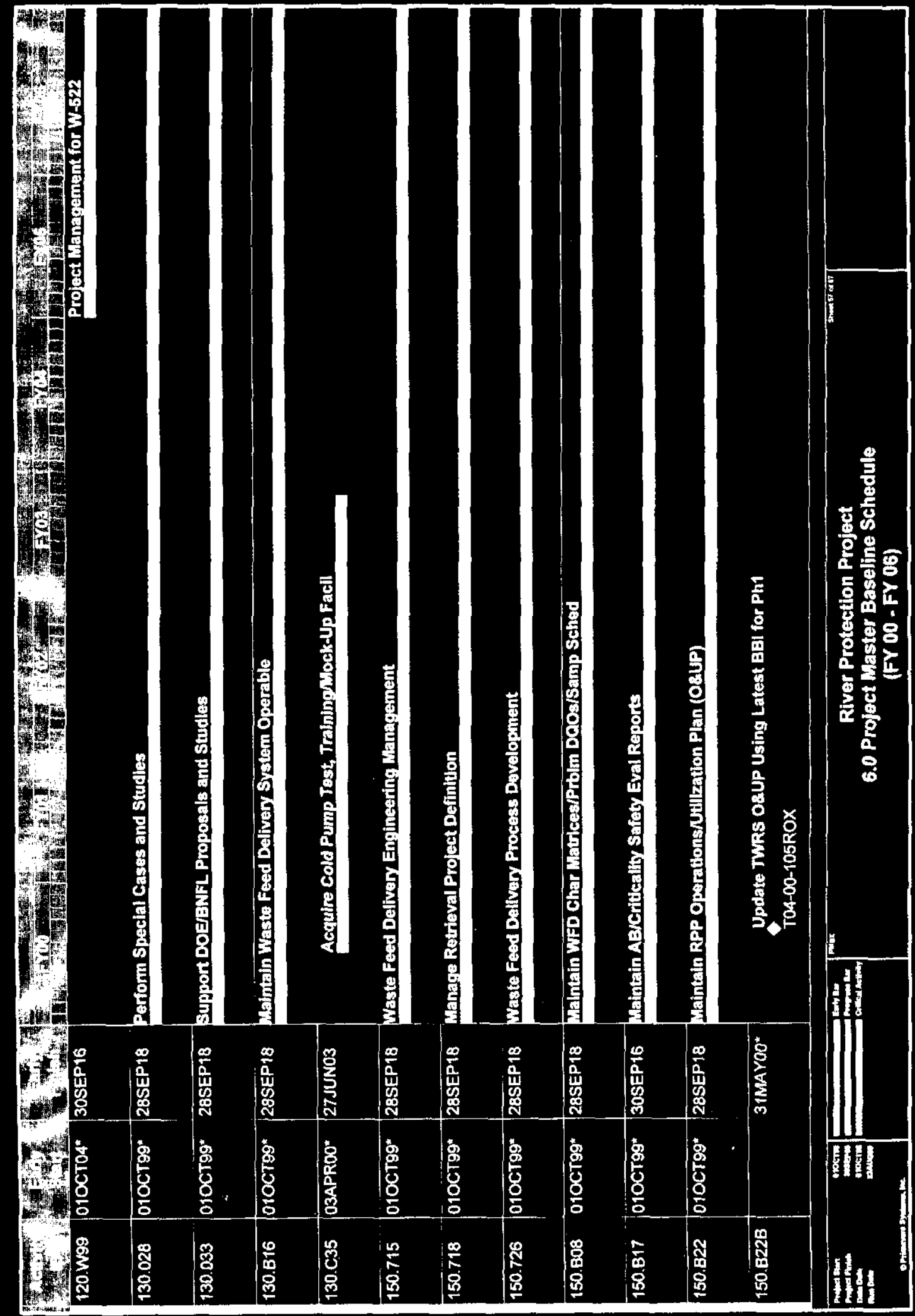




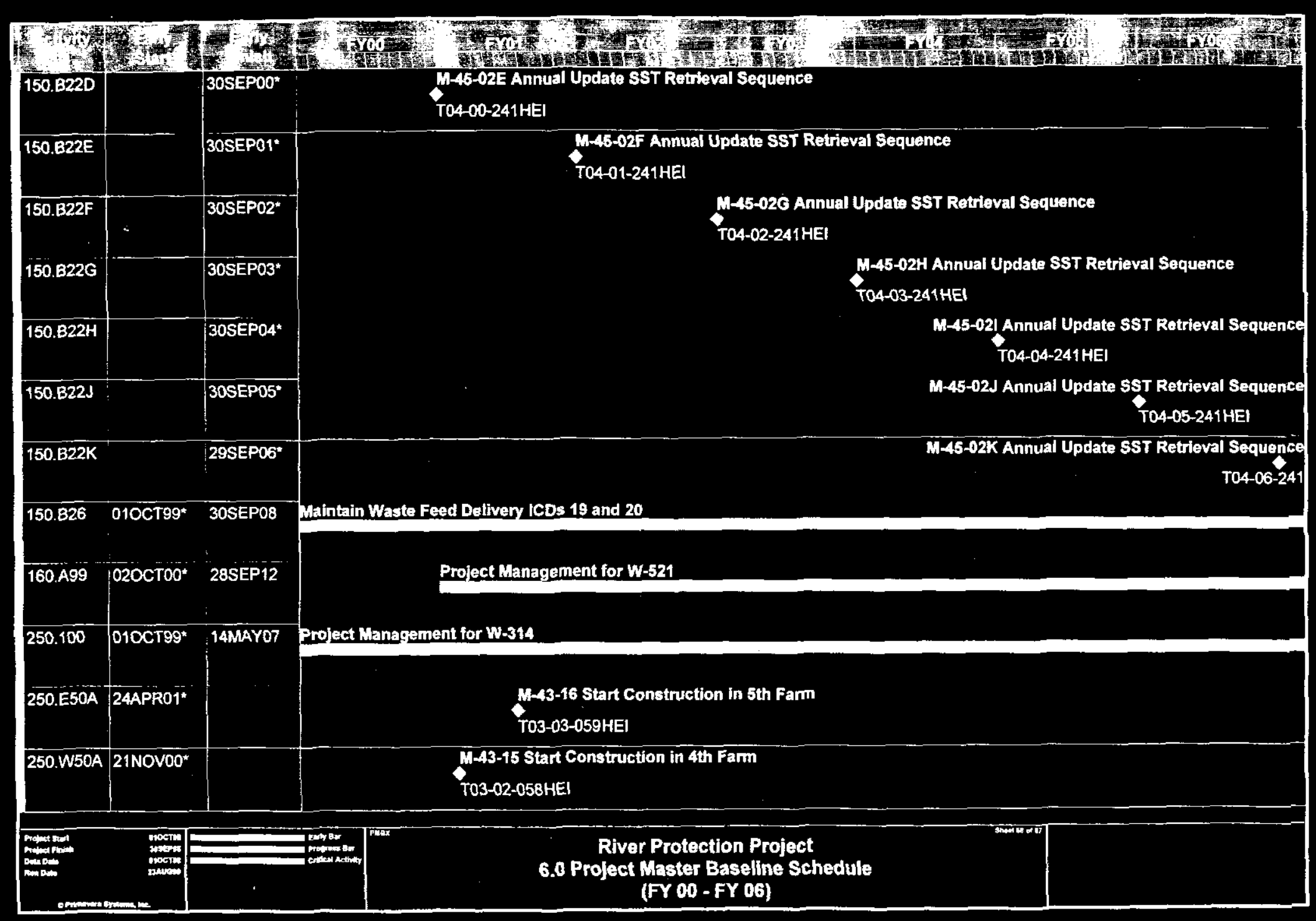

$\frac{2}{0}$
0
0
0
0 


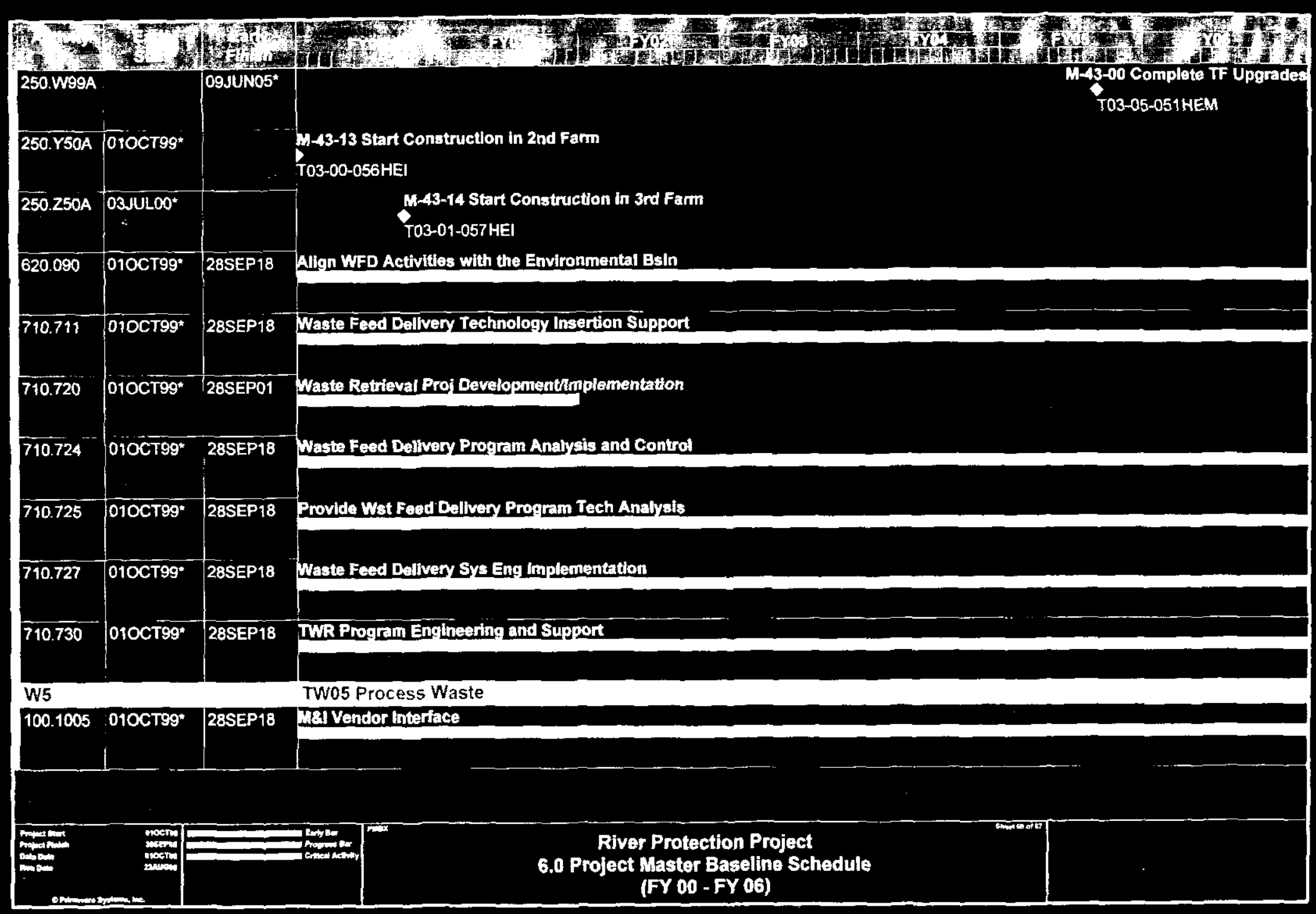




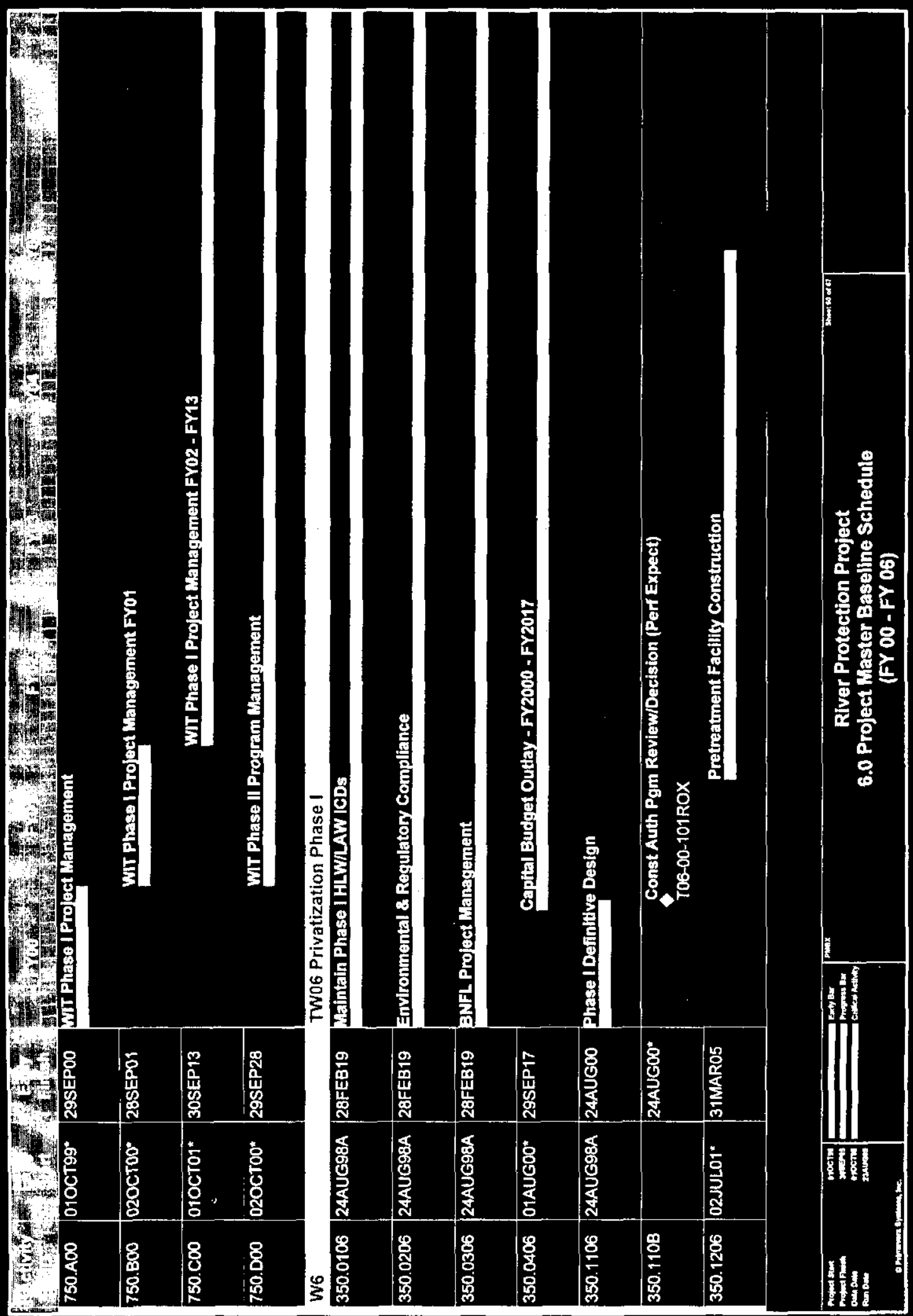




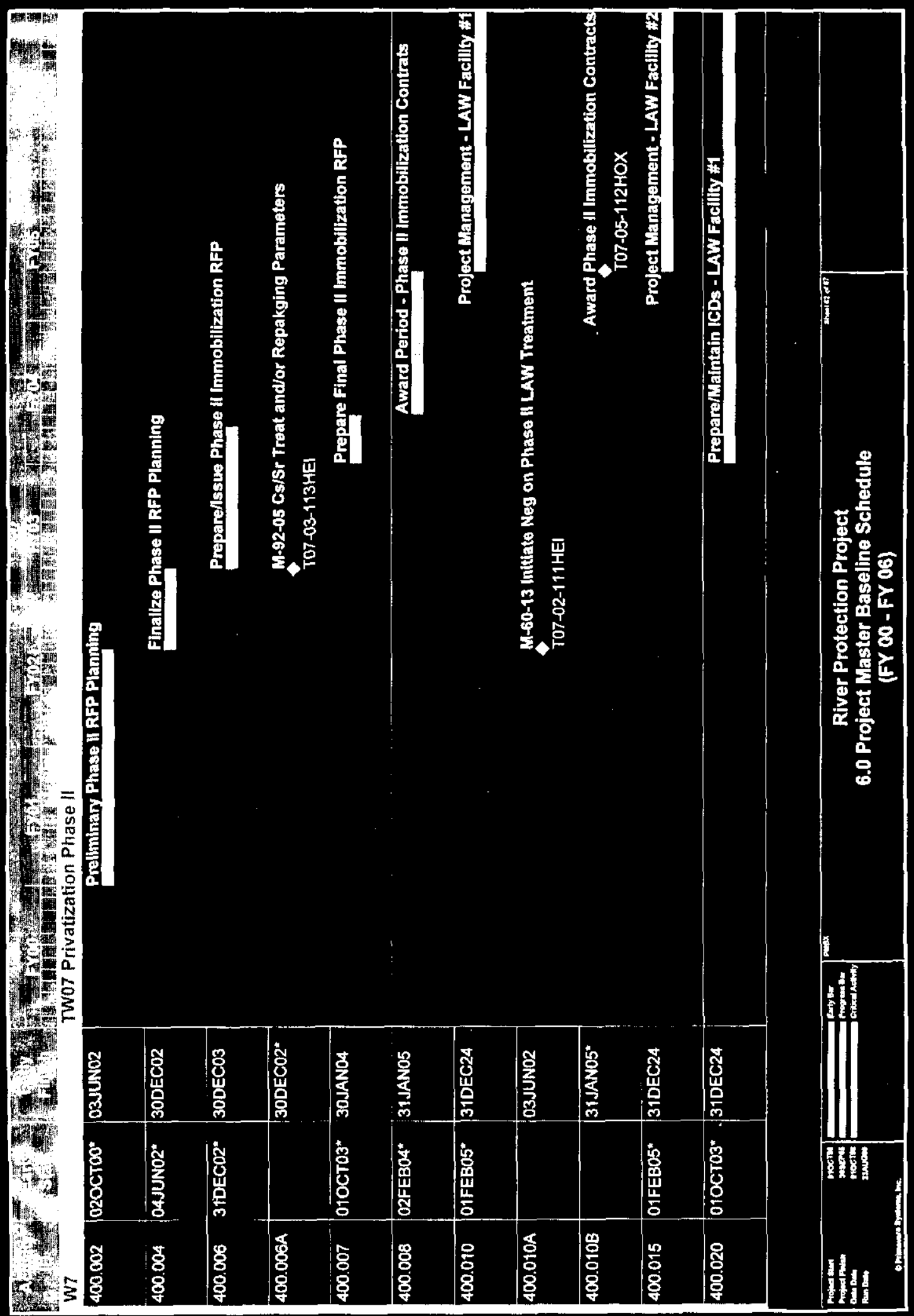


RPP-5044

6-64

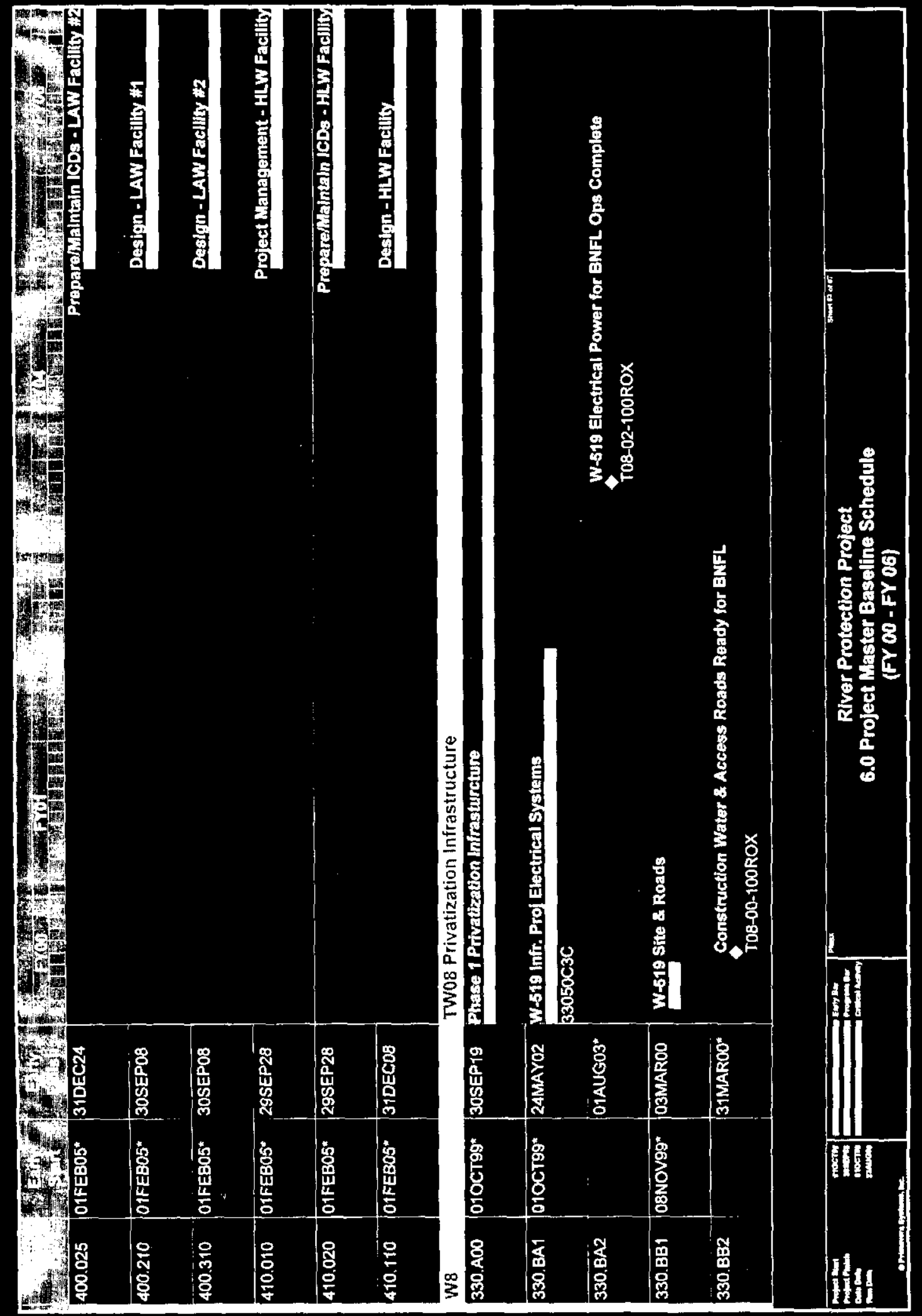




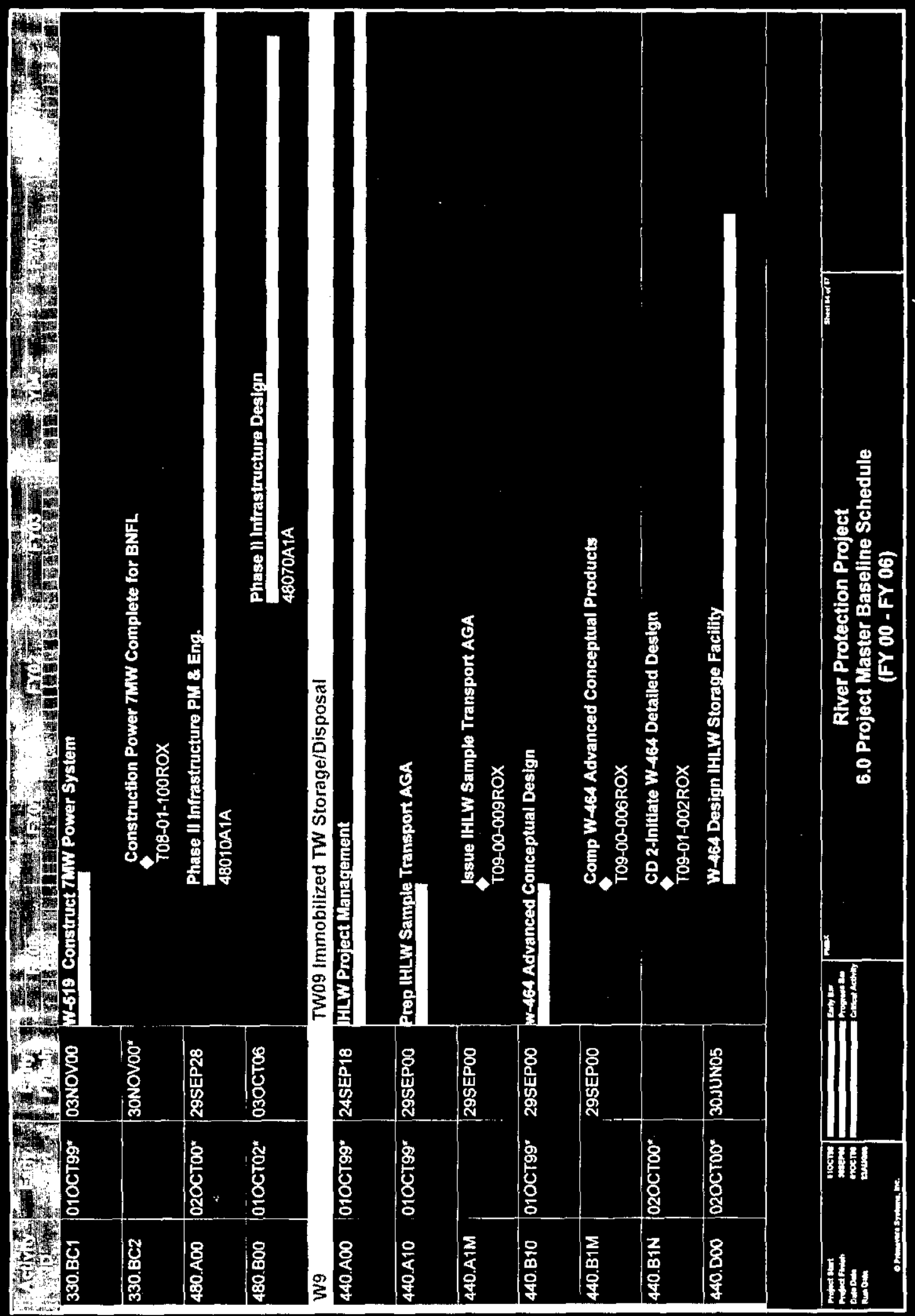




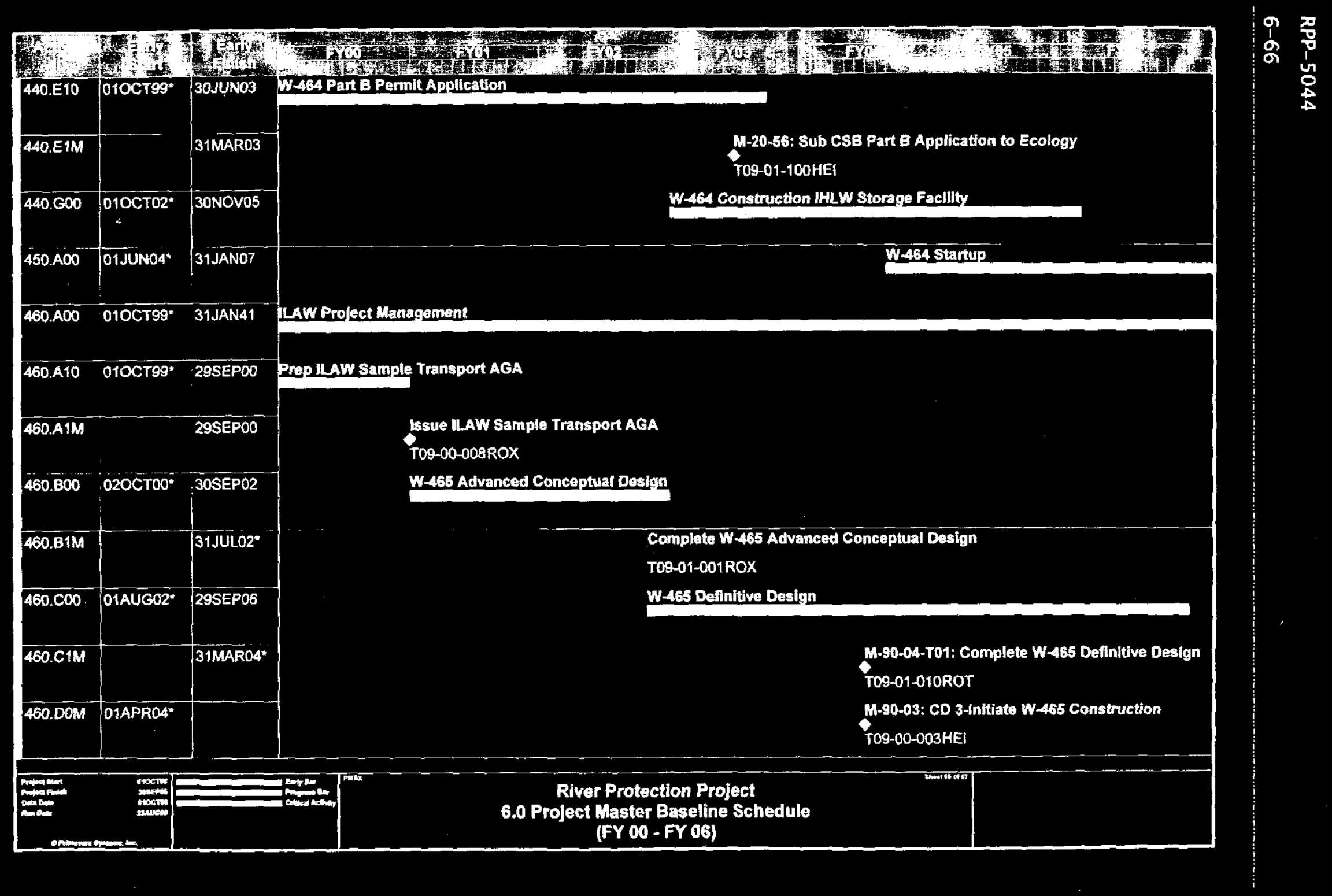




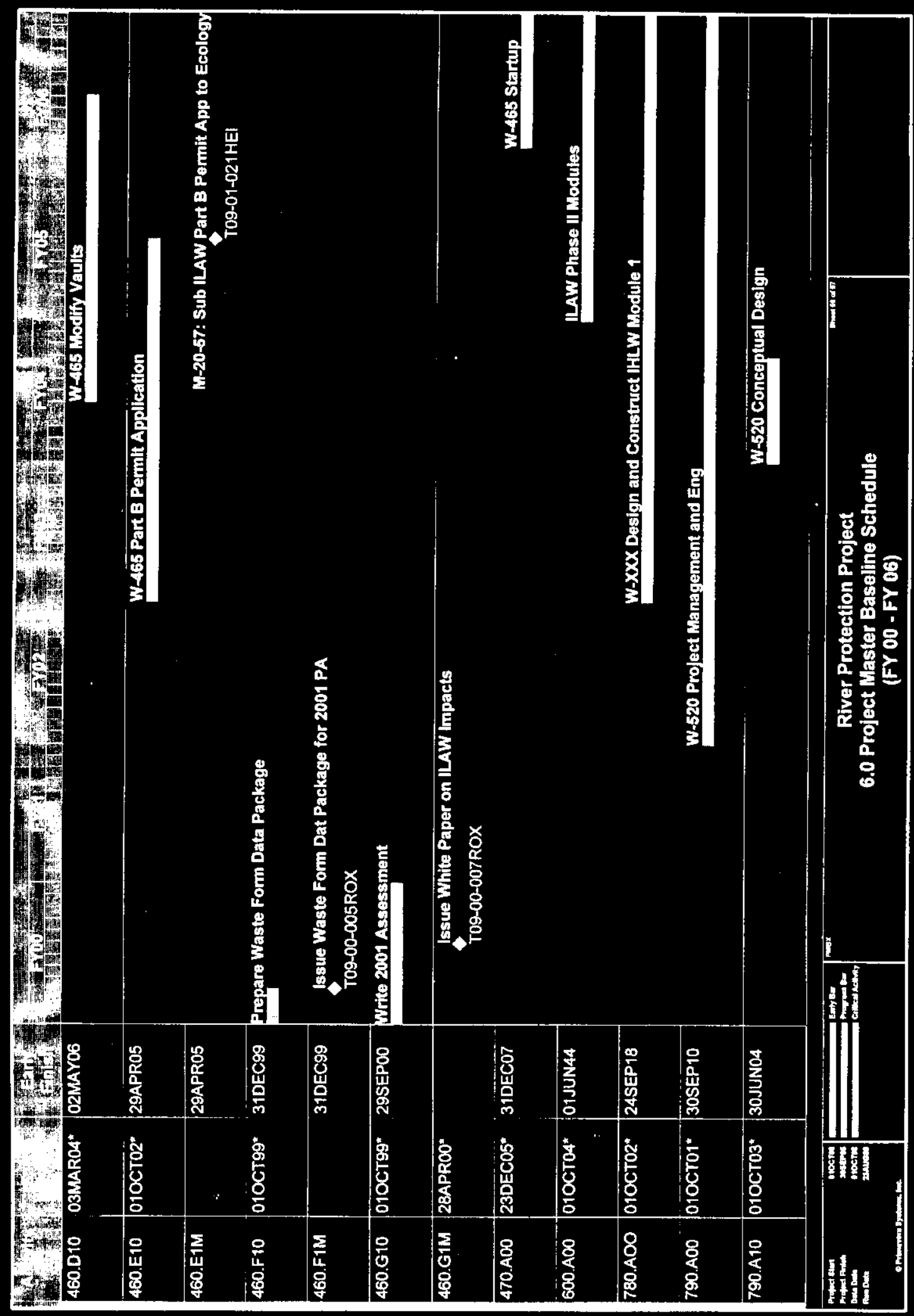


RPP-5044

6-68

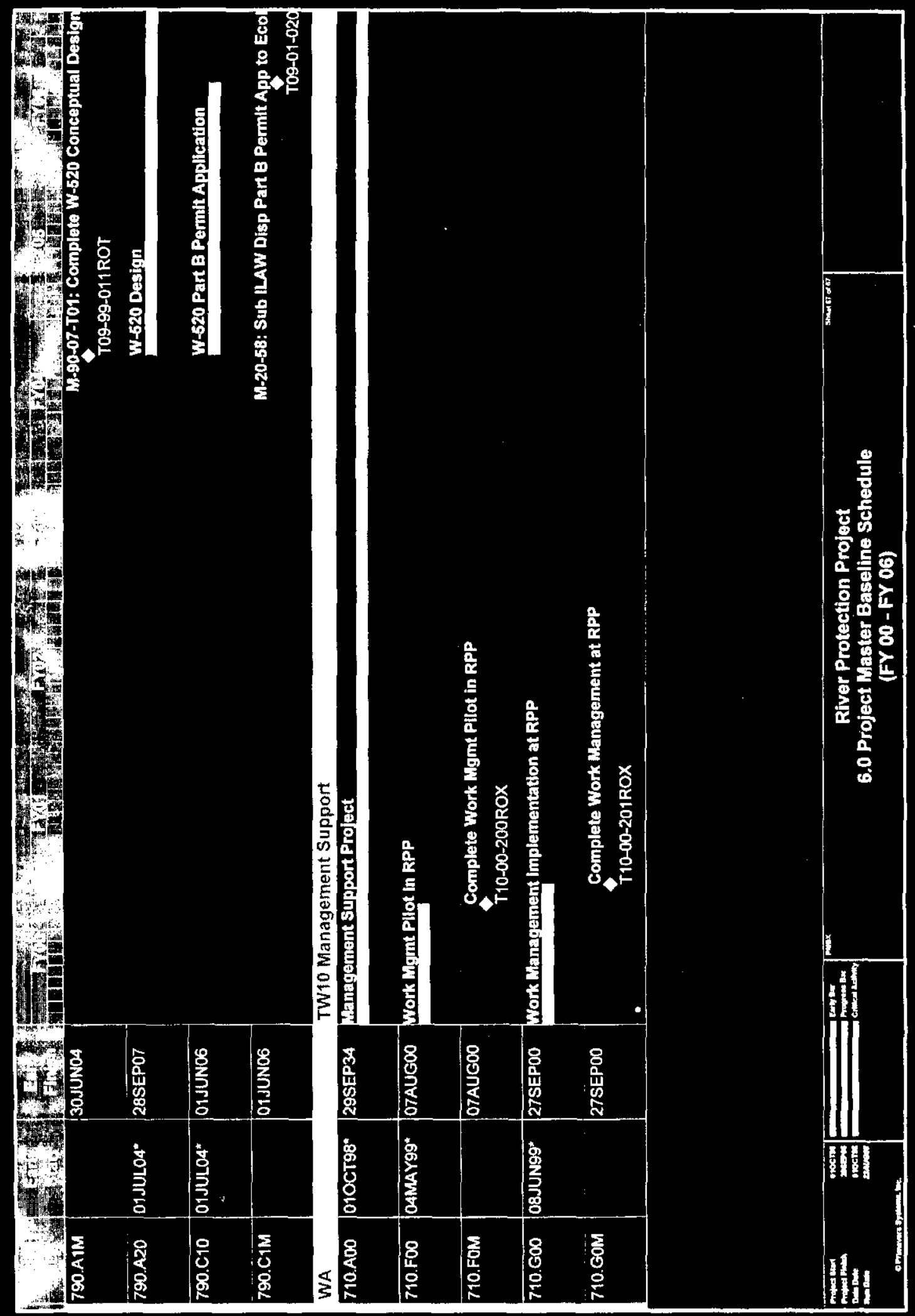


RPP-5044

7-1

\subsection{LIFE-CYCLE COSTS (BY FISCAL YEAR)}




\subsection{Budget Authority (FY 2000 to FY 2006)}

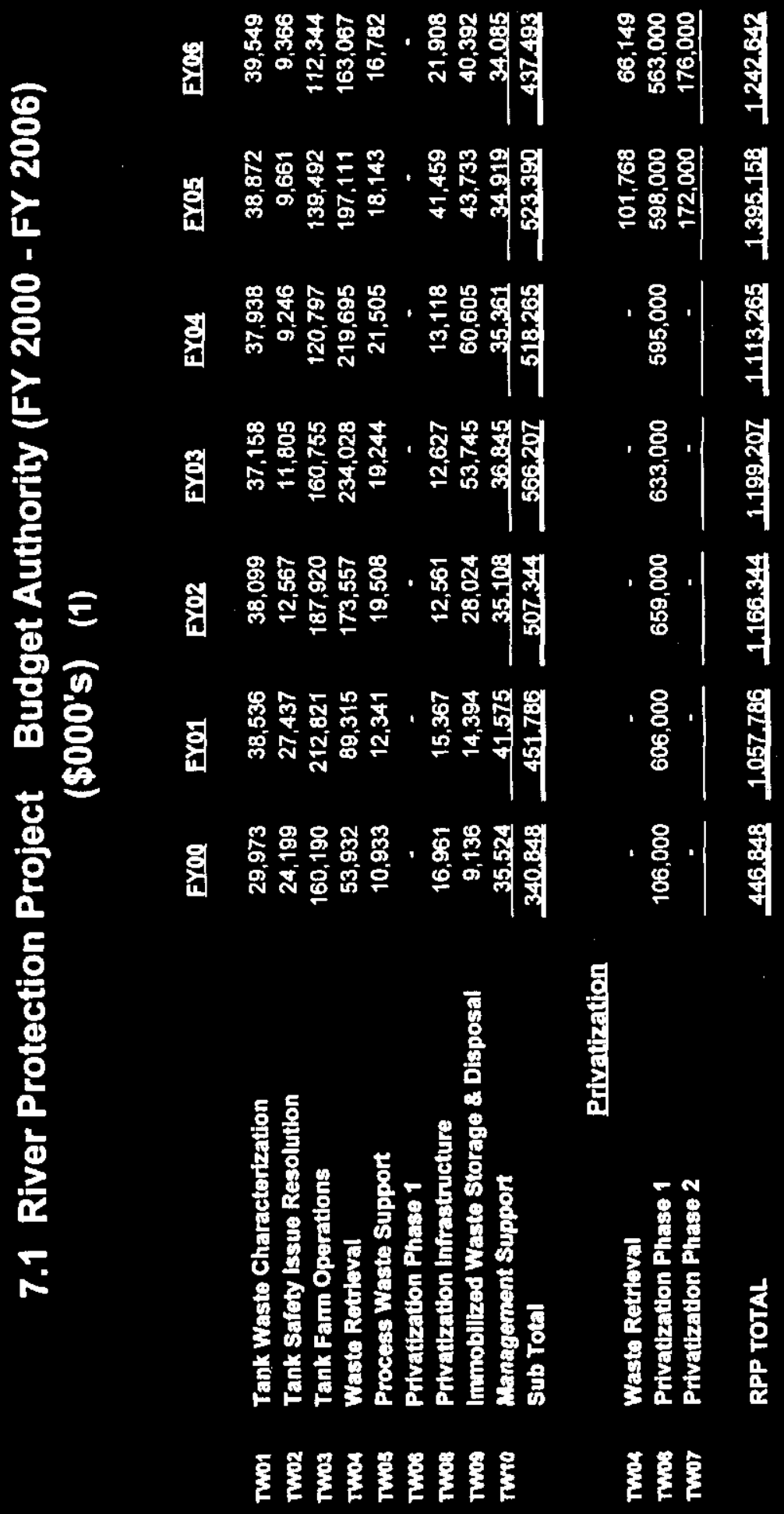




\subsection{Life Cycle Costs (by Fiscal Year)}

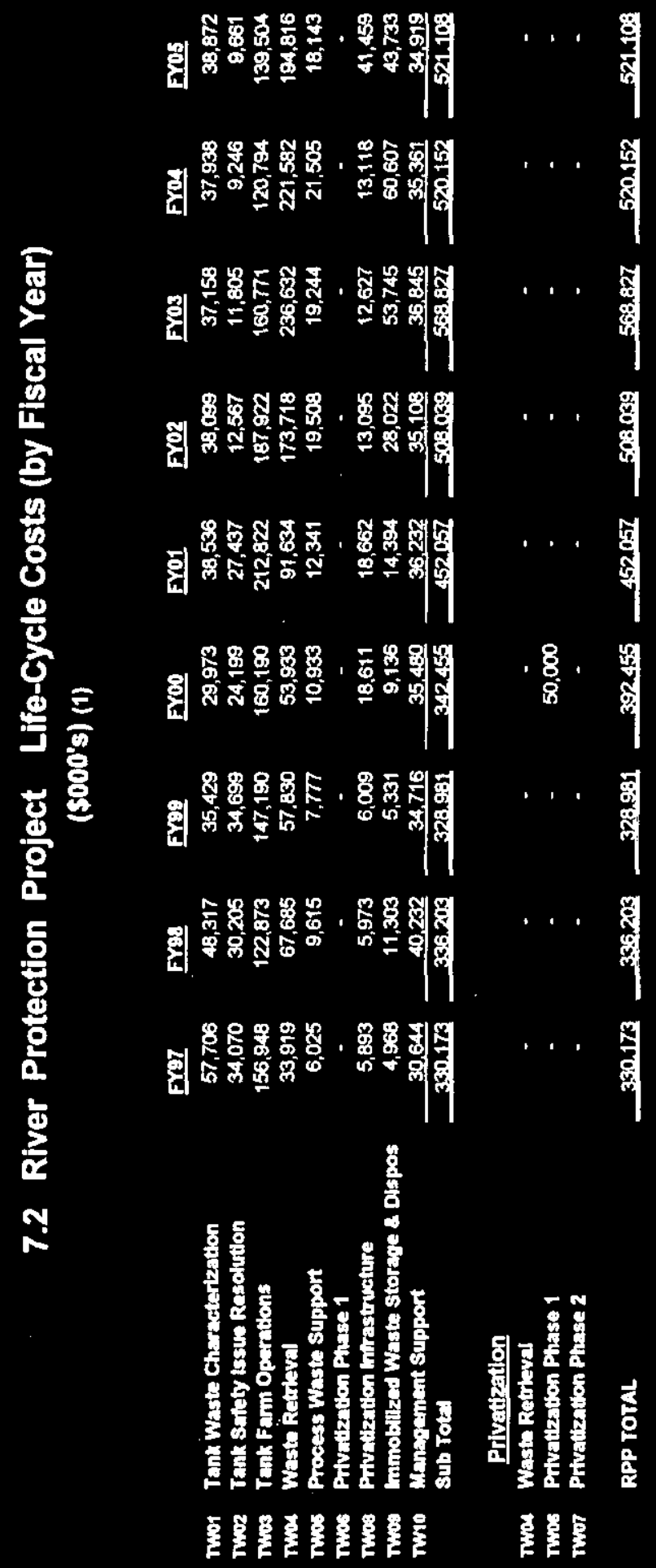


7.2 River Protection Project Life-Cycle Costs (by Fiscal Year)

(5000's) (1)

\begin{tabular}{|c|c|c|c|c|c|c|c|c|c|c|}
\hline & & EYos & EYor & EYo8 & FYog & FY10 & FY11 & FY12 & FY13 & FY14 \\
\hline \multirow{9}{*}{ 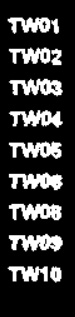 } & Tank Waste Charactertzation & 39,549 & 55,367 & 44,899 & 32,372 & 31,372 & 30,847 & 29,495 & 33,196 & 33,912 \\
\hline & Tank Safety lasue Resolution & 9,366 & 9,561 & 9,762 & - & - & - & - & - & - \\
\hline & Tank Farm Operations & 112,344 & 110,811 & 100,025 & 101,856 & 101,141 & 102,780 & 104,519 & 105,415 & 100,670 \\
\hline & Waste Retrlaval & 163,882 & 225,539 & 219,270 & 213,134 & 167,431 & 134,739 & 166,418 & 189,404 & 118,760 \\
\hline & Process Waste Support & 16,782 & 21,175 & 17,845 & 18,148 & 18,529 & 18,918 & 19,238 & 19,353 & 13,360 \\
\hline & Provatzotion Phase 1 & - & - & - & - & - & - & - & - & - \\
\hline & Prtvattation lunrastructure & 21,908 & 33,384 & 35,067 & $71, \infty 03$ & 73,253 & 35,482 & 110,630 & 112,219 & 115,035 \\
\hline & Inmobilized Waste Storcye \& Dispos & 40,392 & 52,611 & 138.153 & 251,839 & 250,583 & 224,266 & 165,503 & 210,156 & 369,643 \\
\hline & $\begin{array}{l}\text { Manayement Support } \\
\text { sub Total }\end{array}$ & $-\frac{34085}{438 \times 308}$ & $\frac{34,616}{543084}$ & $\frac{35,112}{200,135}$ & $\frac{35,356}{724.296}$ & $\frac{35.911}{678,220}$ & $\frac{36,144}{583,175}$ & $\frac{35,410}{532,214}$ & $\frac{37.143}{70.6897}$ & $\frac{37,392}{78: 771}$ \\
\hline & Privetization & & & & & & & & & \\
\hline Twa & Waste Retrieval & - & 6,268 & 24,463 & 42,041 & 357,400 & 573,953 & 815,943 & 926,982 & $8 \% 6,718$ \\
\hline Twost & Privatization Phase 1 & 50,000 & 188,001 & 401,000 & 908,000 & $1,073,001$ & $1,102,001$ & $1,097,000$ & $1,111,001$ & $1,305,001$ \\
\hline Two & Provathation Phase 2 & - & - & - & - & - & $1,362,000$ & $1,383,000$ & $2,248,000$ & $2,282,000$ \\
\hline & RPP TOTAL & 48,308 & 7373392 & $1,075,509$ & 1674.347 & $230.9,621$ & 3.624 .129 & $3,978,157$ & 4992870 & 5,432491 \\
\hline
\end{tabular}

(1) All dollars displayed contain applicable escalation 
7.2 River Protection Project Life-Cycle Costs (by Fiscal Year) (6000's) (1)

\begin{tabular}{|c|c|c|c|c|c|c|c|c|c|c|}
\hline & & FY15 & FY18 & FY17 & EY18 & FY19 & FY29 & FY21 & FY22 & FY23 \\
\hline Twor & Tank Waste Characterization & 35,418 & 40,358 & 32,191 & 33,125 & 32,110 & 32,929 & 33,394 & 34,034 & 34,444 \\
\hline $\min 2$ & Tank satrety lasue Resolution & - & - & - & - & - & - & - & - & - \\
\hline nom & Tank Farm Operations & 103,519 & 105,268 & 106,646 & 109,738 & 111,607 & 114,394 & 118,160 & $\uparrow 19, œ 4$ & 120,766 \\
\hline Tim & Waste Rotrieval & 77,702 & 55,678 & 41,589 & 41,012 & 13,514 & 13,805 & 24,319 & 24,969 & 33,410 \\
\hline Twos & Procass Waste Support & 13,640 & 13,981 & 14,162 & 14,444 & 14,584 & 14,949 & 15,210 & 15,530 & 15,793 \\
\hline $\min$ & Prwatization Phase 1 & - & - & - & 2,484 & 12,436 & 51,348 & 71,852 & 29,288 & - \\
\hline Twos & Privatization Infrastructure & 117,450 & 120,394 & 121,947 & 125,006 & 119,600 & 108,581 & 110,422 & 112,741 & 114,649 \\
\hline $\operatorname{Tn}$ & Immobilized Waste Storage \& Dispos & 463,178 & 463,141 & 351,525 & 355,171 & 268,791 & 218,986 & 121,494 & 69,351 & 58,101 \\
\hline Twio & $\begin{array}{l}\text { Management Support } \\
\text { Sub Total }\end{array}$ & $\begin{array}{r}37.824 \\
84.7371 \\
\end{array}$ & $\begin{array}{r}38,419 \\
8372 \times 39\end{array}$ & $\begin{array}{r}38.757 \\
70.6 .817\end{array}$ & $\begin{array}{r}39,027 \\
220,027\end{array}$ & $\frac{39,651}{612,351}$ & $\begin{array}{r}40,491 \\
595,483\end{array}$ & $\begin{array}{r}40,622 \\
535,473 \\
\end{array}$ & $\begin{array}{r}41,127 \\
46,747 \\
\end{array}$ & $\begin{array}{r}41,686 \\
418.850 \\
\end{array}$ \\
\hline & Privatization & & & & & & & & & \\
\hline Twa & Waste Retrieval & 959,183 & 697,408 & 612,068 & 382,342 & 4,097 & 806 & - & . & - \\
\hline Two & Privatization Pha & $1,437,723$ & $1,230,001$ & 463,000 & . & - & - & - & - & - \\
\hline $\operatorname{mon}$ & Privatization Phase 2 & $2,317,000$ & $1,291,000$ & $1,311,000$ & 602,000 & 611,000 & 620,000 & 629,000 & 639,000 & 648,000 \\
\hline & RPP TOTAL & 55.52037 & $4,255,648$ & $3,092,885$ & 1704,349 & $1,227,449$ & $1,216,289$ & $1.164,473$ & 1085,747 & $1,065,850$ \\
\hline
\end{tabular}

(1) All dollars displayed contain applicable escalation 


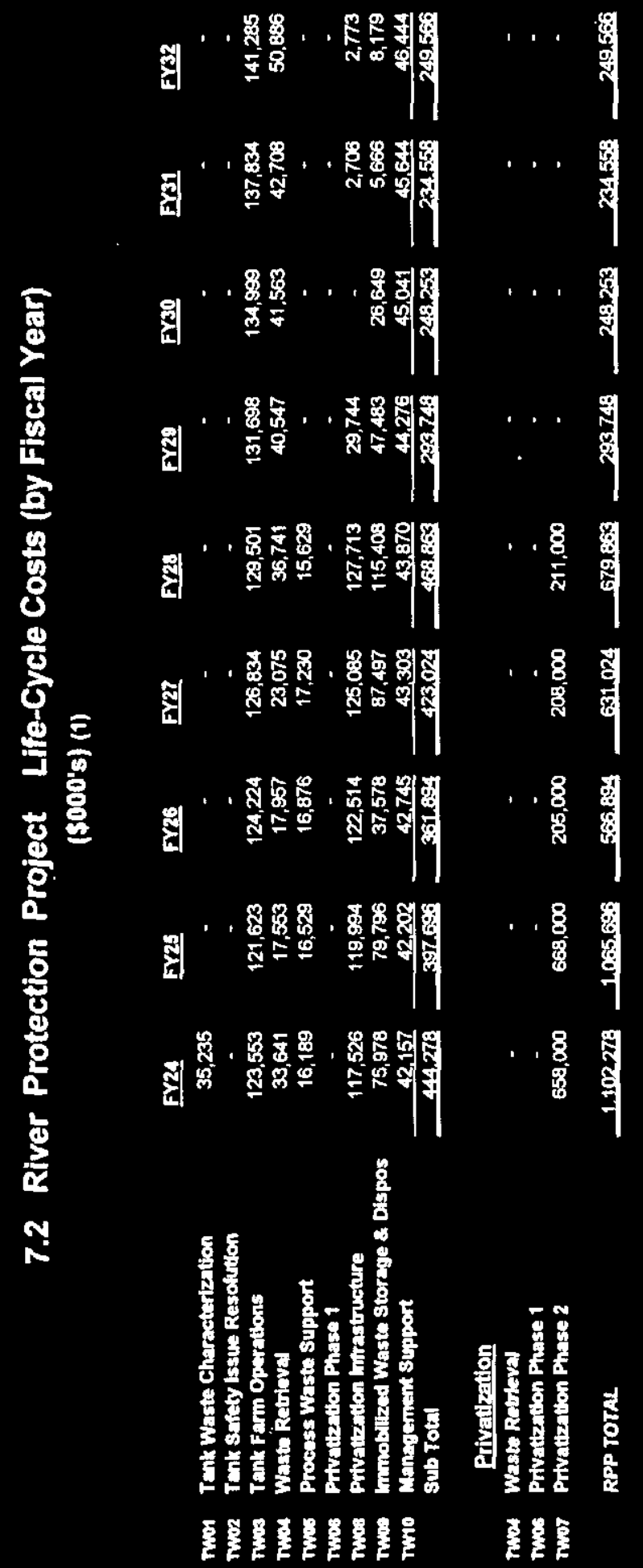




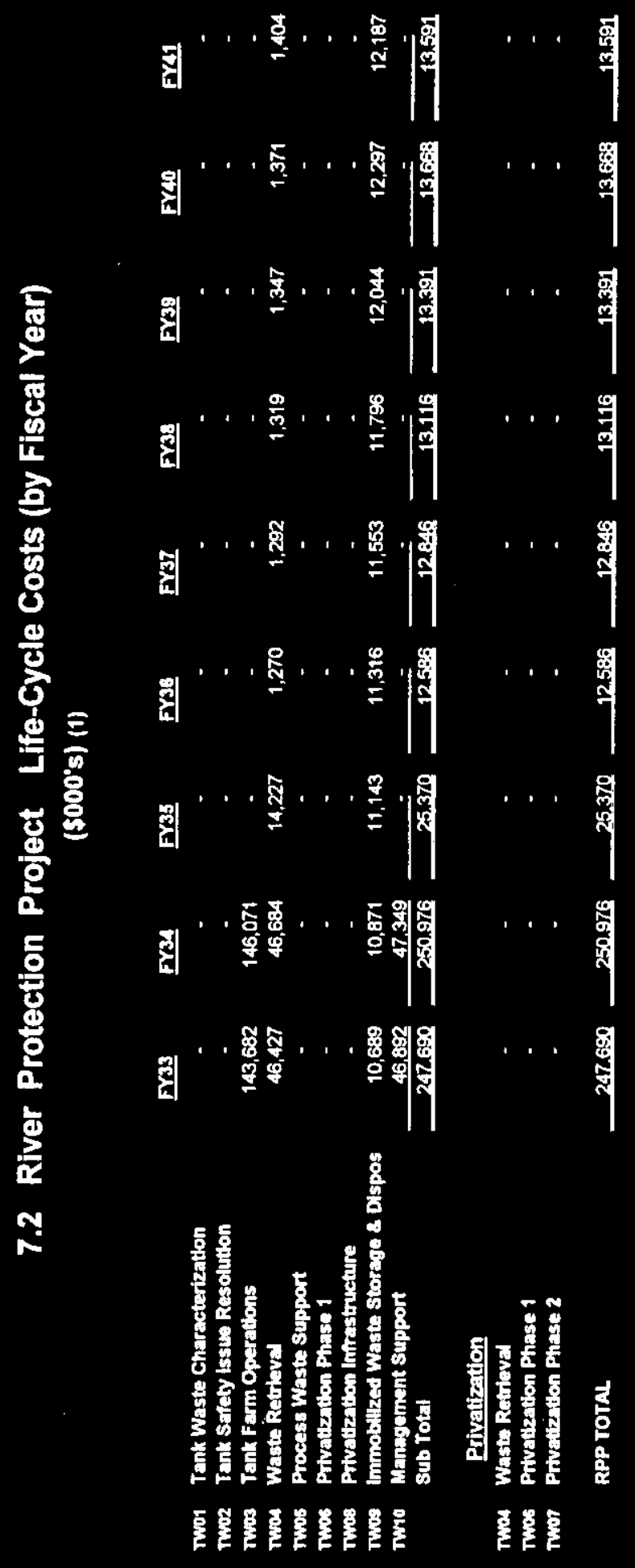


RPP-5044

$$
\text { 7-8 }
$$

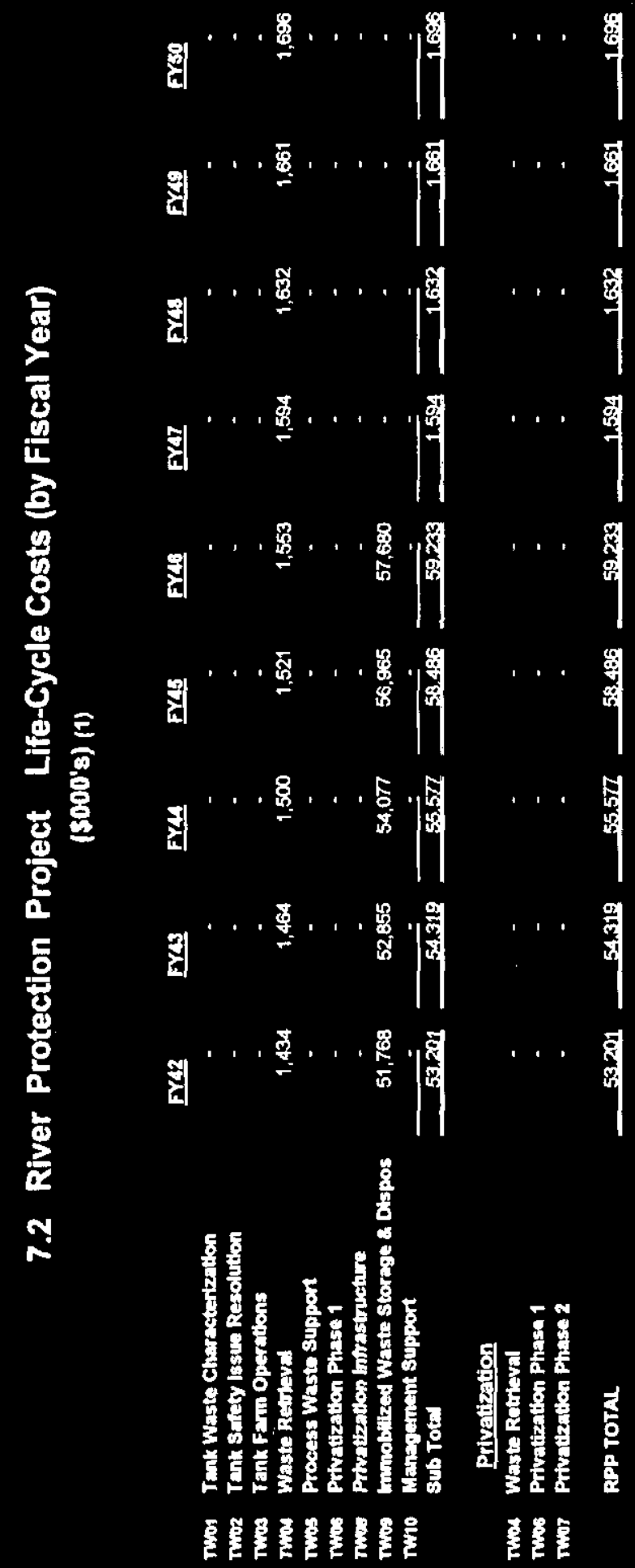



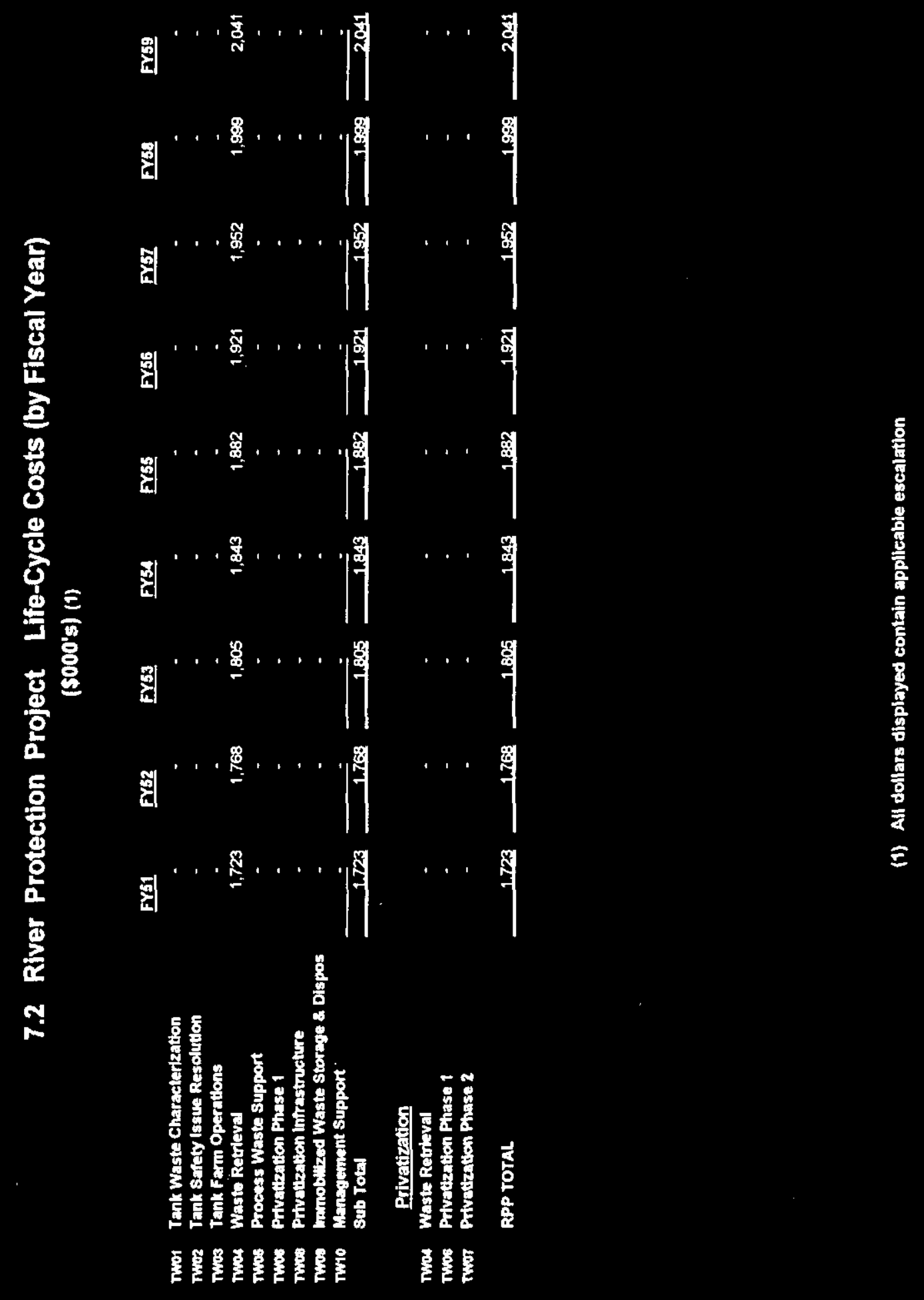
RPP-5044

7-10

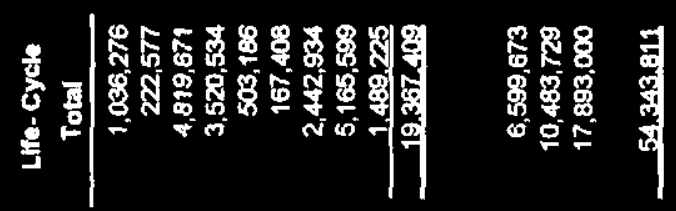

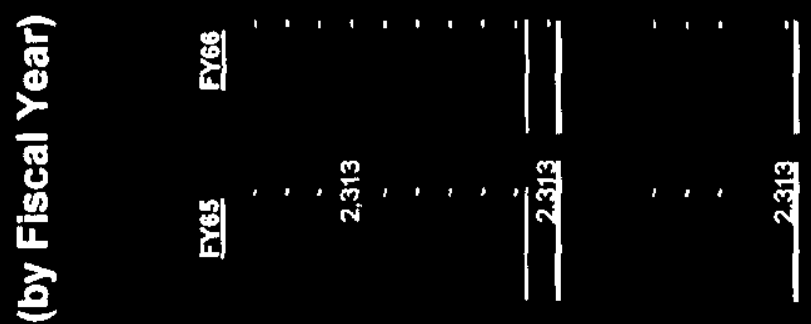

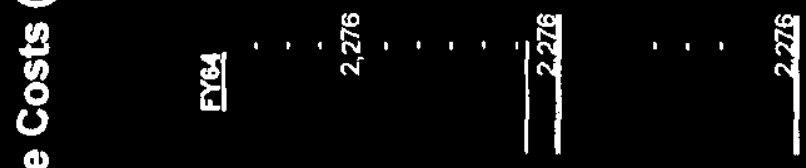

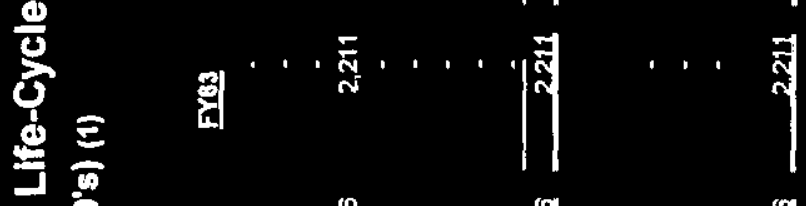

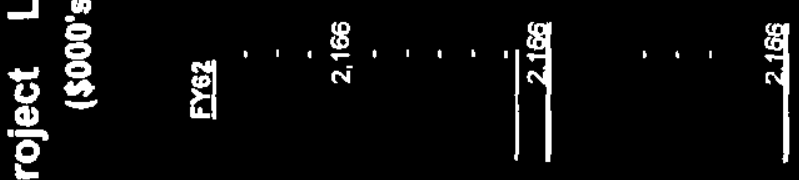

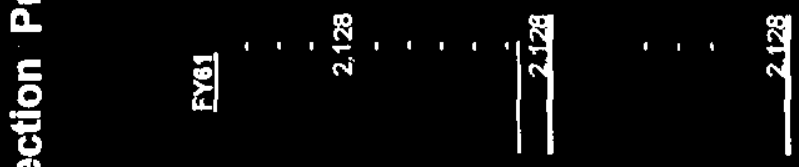

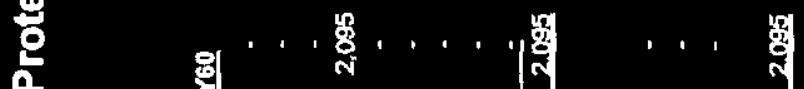

䀘

点

Y

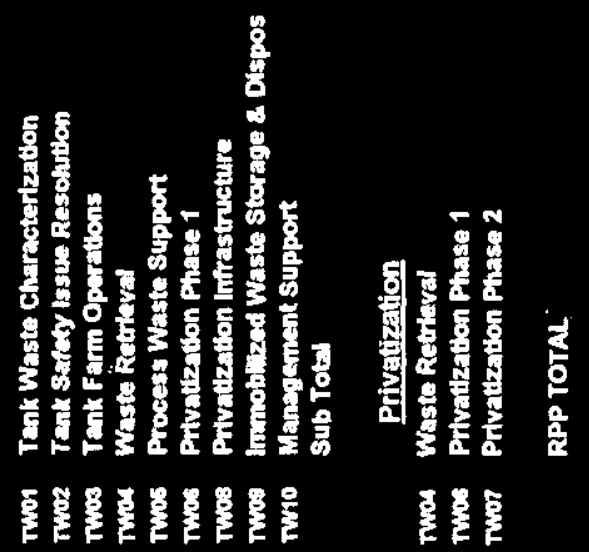




\subsection{MAIOR RISKS AND MITIGATION ACTIONS}

Major Risk and Mitigation Actions

\begin{tabular}{|c|c|c|c|c|c|}
\hline $\begin{array}{c}\text { Risk } \\
\text { Number }\end{array}$ & Risk Title & $\begin{array}{c}\text { Risk } \\
\text { Owner }\end{array}$ & Issue & Baseline Risk & Mitigating Actions \\
\hline CR-032 & $\begin{array}{l}222-S \\
\text { Analytical } \\
\text { Laboratory } \\
\text { Capability }\end{array}$ & $\begin{array}{l}\text { Waste Feed } \\
\text { Delivery }\end{array}$ & $\begin{array}{l}\text { High-quality, } \\
\text { accurate waste } \\
\text { analysis for } \\
\text { certification of } \\
\text { transfers to BNFL } \\
\text { Inc. cannot be } \\
\text { provided unless } \\
\text { the 222-S } \\
\text { Laboratory staff, } \\
\text { skill level, } \\
\text { training, and } \\
\text { technical } \\
\text { capability are } \\
\text { established and } \\
\text { maintained } \\
\text { throughout the } \\
\text { Phase } 1 \text { work } \\
\text { scope }\end{array}$ & $\begin{array}{l}\text { If the analytical } \\
\text { certification } \\
\text { requirements are not } \\
\text { consistent with a level- } \\
\text { load staffing plan, the } \\
\text { turnaround time and } \\
\text { cost of analytical } \\
\text { services will increase. } \\
\text { Note: Laboratory } \\
\text { risks also appear under } \\
\text { "Human Resources" }\end{array}$ & $\begin{array}{l}\text { 1. Evaluate BNFL } \\
\text { Inc. contract for } \\
\text { requirements to use } \\
222-S \text { and/or WSCF } \\
\text { laboratories } \\
\text { (TBR } 150 . B 29 \text { ). } \\
\text { 2. Evaluate backup } \\
\text { laboratory option. }\end{array}$ \\
\hline CR-046 & $\begin{array}{l}\text { LMHC Funding } \\
\text { for } 80 \% \\
\text { Confidence of } \\
\text { Success }\end{array}$ & $\begin{array}{l}\text { Planning } \\
\text { and } \\
\text { Integration }\end{array}$ & $\begin{array}{l}\text { DOE Budget } \\
\text { allocation will not } \\
\text { support LMHC } \\
\text { annual funding } \\
\text { requirements, } \\
\text { including } \\
\text { sufficient risk } \\
\text { mitigation funding } \\
\text { to ensure an } 80 \% \\
\text { confidence of } \\
\text { successfully } \\
\text { executing the RPP } \\
\text { mission }\end{array}$ & $\begin{array}{l}\text { If out-year funding for } \\
\text { LMHC activities does } \\
\text { not match the } \\
\text { requirments, LMHC } \\
\text { may not be able to } \\
\text { support the } \\
\text { April } 1,1999 \\
\text { guidance. }\end{array}$ & $\begin{array}{l}\text { 1. Ensure FYO0 } \\
\text { MYWP submittal } \\
\text { supports } \\
\text { June } 21,1999 \\
\text { Baseline Updating } \\
\text { Guidance. } \\
\text { 2. Validate } \\
\text { sufficiency of } \\
\text { funding during } \\
\text { update to the baseline } \\
\text { that will be } \\
\text { performed in } \\
\text { FY } 1999 \\
\text { (TBR } 720.740 \text { ). } \\
\text { 3. Implement SST } \\
\text { Retrieval Program } \\
\text { Plan }\end{array}$ \\
\hline
\end{tabular}


RPP-5044

8-2

\section{Major Risk and Mitigation Actions}

\begin{tabular}{|c|c|c|c|c|c|}
\hline $\begin{array}{c}\text { Risk } \\
\text { Number }\end{array}$ & Risk Title & $\begin{array}{l}\text { Risk } \\
\text { Owner }\end{array}$ & Issue & Baseline Risk & Mitigating Actions \\
\hline CR-065 & $\begin{array}{l}\text { Maintaining } \\
\text { Configuration } \\
\text { Management of } \\
\text { Critical } \\
\text { Drawings }\end{array}$ & Projects & $\begin{array}{l}\text { Projects are not } \\
\text { currently required } \\
\text { or funded to } \\
\text { incorporate } \\
\text { outstanding ECNs } \\
\text { for work } \\
\text { completed or to } \\
\text { perform physical } \\
\text { verification efforts } \\
\text { before the design } \\
\text { phase begins }\end{array}$ & $\begin{array}{l}\text { If critical baseline } \\
\text { plant drawings are not } \\
\text { current and accurate at } \\
\text { design phase initiation, } \\
\text { delays in design, } \\
\text { construction, and } \\
\text { turnover phases may } \\
\text { occur because } \\
\text { reconciliation of } \\
\text { project drawings with } \\
\text { plant drawings is } \\
\text { required for } \\
\text { completion of ORR. }\end{array}$ & $\begin{array}{l}\text { 1. Continue the } \\
\text { Operations As- } \\
\text { Building Project to } \\
\text { develop Operational } \\
\text { P\&IDs, incorporate } \\
\text { ECNs, and perform } \\
\text { field verification of } \\
\text { plant-essential H-2 } \\
\text { drawings as defined } \\
\text { on the Tank Farm } \\
\text { Essential Drawing } \\
\text { Plan. } \\
2 \text { Projects will } \\
\text { include ECN } \\
\text { incorporation and } \\
\text { field verification } \\
\text { activities for those } \\
\text { drawings not covered } \\
\text { under the Operations } \\
\text { As-Building Project. } \\
\text { 3. Projects will } \\
\text { reconcile project } \\
\text { drawings with plant } \\
\text { drawings before the } \\
\text { ORR. }\end{array}$ \\
\hline
\end{tabular}


Major Risk and Mitigation Actions

\begin{tabular}{|c|c|c|c|c|c|}
\hline $\begin{array}{c}\text { Risk } \\
\text { Number }\end{array}$ & Risk Title & $\begin{array}{c}\text { Risk } \\
\text { Owner }\end{array}$ & Issue & Baseline Risk & Mitigating Actions \\
\hline CR-070 & $\begin{array}{l}\text { Increasing } \\
\text { Obsolescence/ } \\
\text { Deterioration of } \\
\text { Tank Farm and } \\
\text { Its } \\
\text { Infrastructure }\end{array}$ & $\begin{array}{l}\text { Waste Feed } \\
\text { Delivery }\end{array}$ & $\begin{array}{l}\text { SSTs have } \\
\text { exceeded their } \\
\text { design lives and } \\
\text { much of the } \\
\text { supporting piping, } \\
\text { utility, and } \\
\text { infrastructure, and } \\
\text { many DSTS are } \\
\text { deteriorating. }\end{array}$ & $\begin{array}{l}\text { If LMHC loses one or } \\
\text { more DSTS or suffers } \\
\text { repeated failure of } \\
\text { infrastructure support } \\
\text { operating equipment } \\
\text { as a result of overall } \\
\text { funding delays or } \\
\text { reductions, this will } \\
\text { force reduction of } \\
\text { emergency tank } \\
\text { reserve capacity, and } \\
\text { slow the retrieval and } \\
\text { waste feed delivery } \\
\text { activities. }\end{array}$ & $\begin{array}{l}\text { 1. Perform walk } \\
\text { downs and } \\
\text { evaluations of } \\
\text { existing systems. } \\
\text { 2.Conduct and } \\
\text { complete RAM } \\
\text { analysis. } \\
\text { 3. Complete integrity } \\
\text { assessment/ corrosion } \\
\text { studies. } \\
\text { 4. Develop and fund } \\
\text { a comprehensive } \\
\text { maintenance and } \\
\text { spare parts program } \\
\text { (TBR } 130 . B 05 \text { ). } \\
\text { 5. Ensure } \\
\text { redundancy in piping } \\
\text { and high-risk } \\
\text { infrastructure. }\end{array}$ \\
\hline $\begin{array}{l}\text { DOE } \\
\text { DST } \\
\text { ECP } \\
\text { FY } \\
\text { LMHC } \\
\text { MYWP }\end{array}$ & $\begin{array}{l}\text { U.S. Department } \\
\text { double-shell tank } \\
\text { Engineering Chan } \\
\text { fiscal year } \\
\text { Lockheed Martin } \\
\text { multi-year work p }\end{array}$ & $\begin{array}{l}\text { Energy } \\
\text { Notice } \\
\text { anford Corp }\end{array}$ & $\begin{array}{l}\text { P\&ID } \\
\text { RAM } \\
\text { RPP } \\
\text { TBR } \\
\text { WSCF }\end{array}$ & $\begin{array}{l}\text { River Protection Pro } \\
\text { Technical Basis Rev } \\
\text { Waste Sampling and } \\
\text { Facility }\end{array}$ & haracterization \\
\hline
\end{tabular}


RPP-5044

8-4

This page intentionally left blank. 


\subsection{PROJECT BASELINE SUMMARY OVERVIEWS}

\subsection{TANK WASTE CHARACTERIZATION (TW01)}

\subsubsection{Mission Statement}

Tank Waste Characterization (TW01) was established to characterize the Hanford Site high-level radioactive waste and to ensure safe storage and retrieval or disposal of this waste. This waste is stored in large, underground double-shell tanks and single-shell tanks. The work involved is to plan, sample, and analyze the tank waste, and report its contents. Activities include the following: program management, characterization data development, sampling equipment, samples and measurements, and sample analyses. 
RPP-5044

9-2

9.1.2 Life-Cycle Costs by Fiscal Year

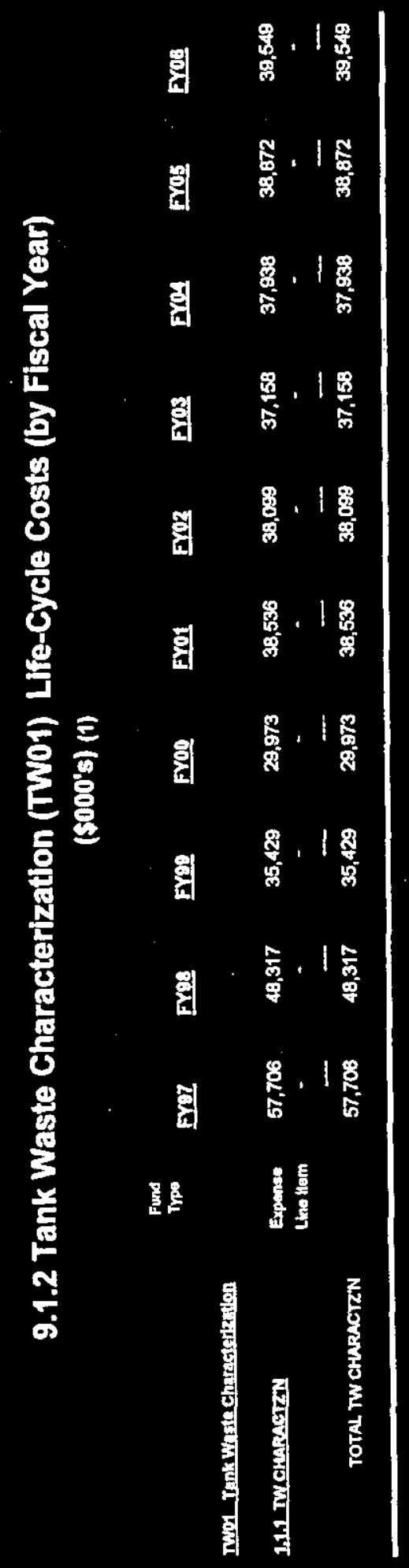




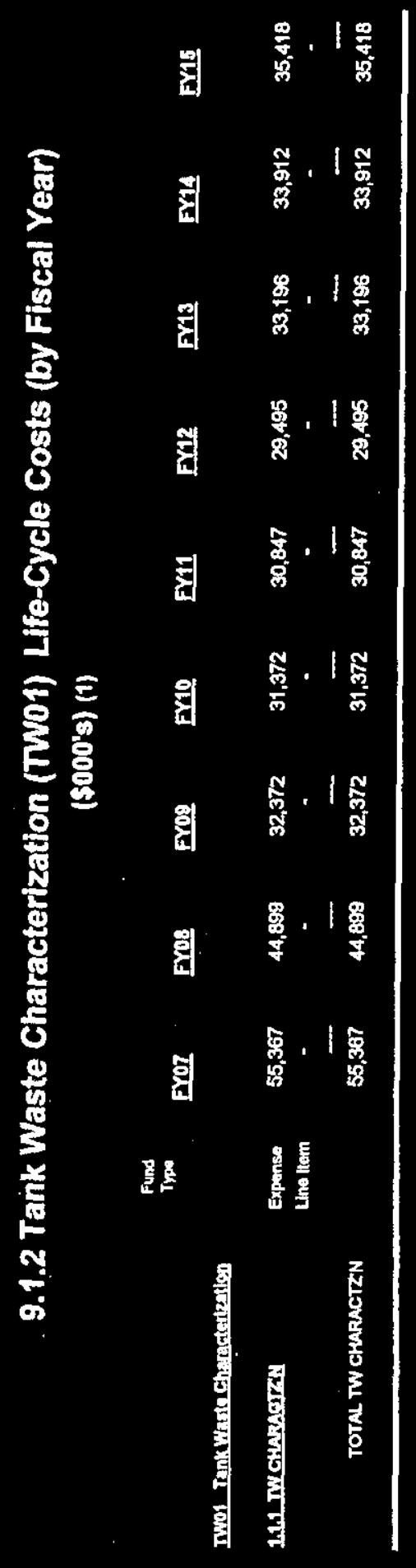


RPP-5044

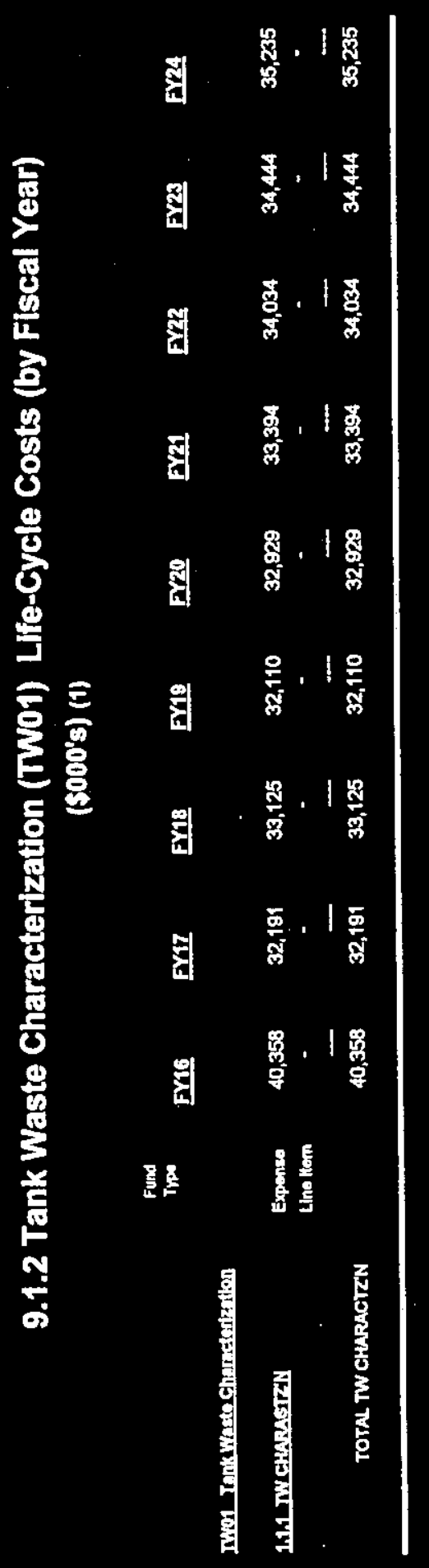




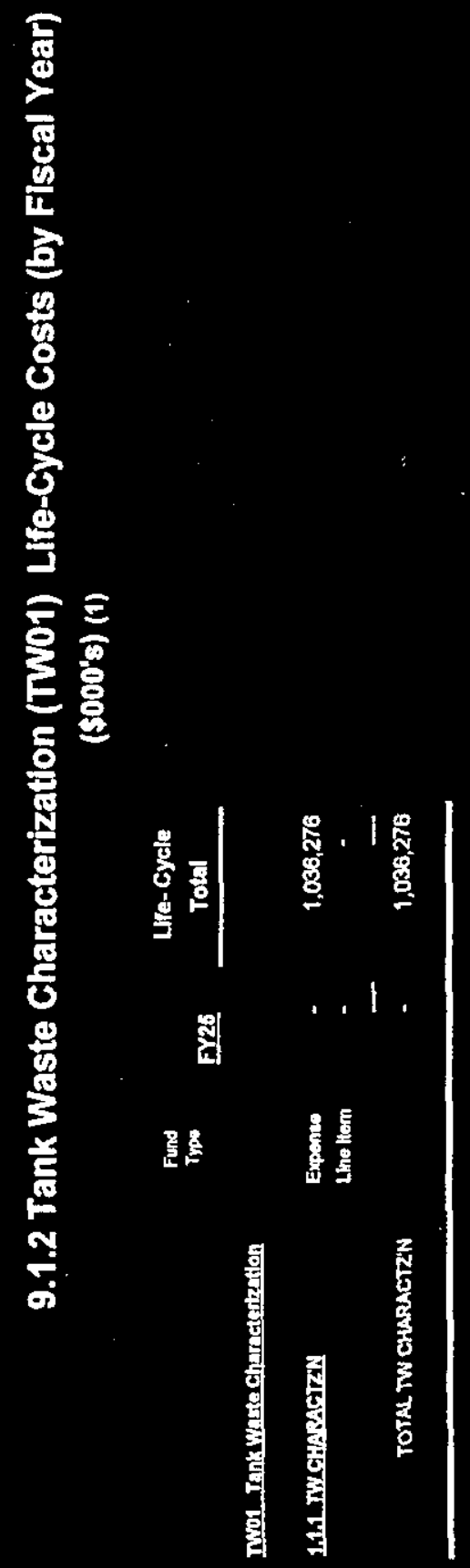


RPP -5044

9-6

9.1.3 Budget Profile by Month (Execution Year)

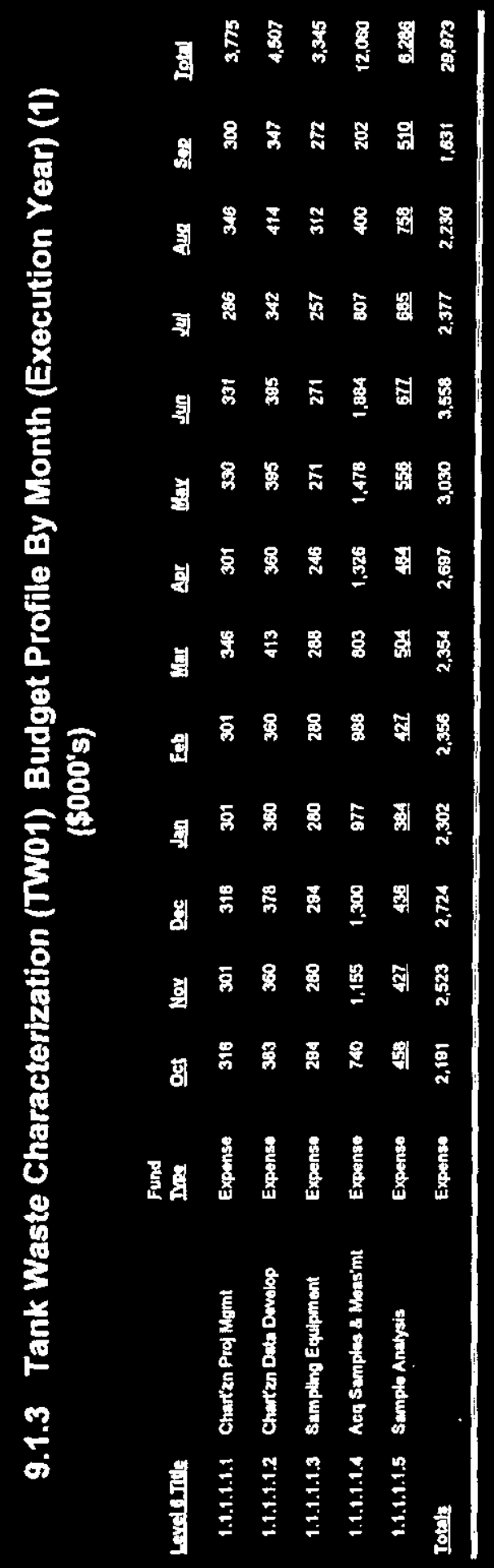




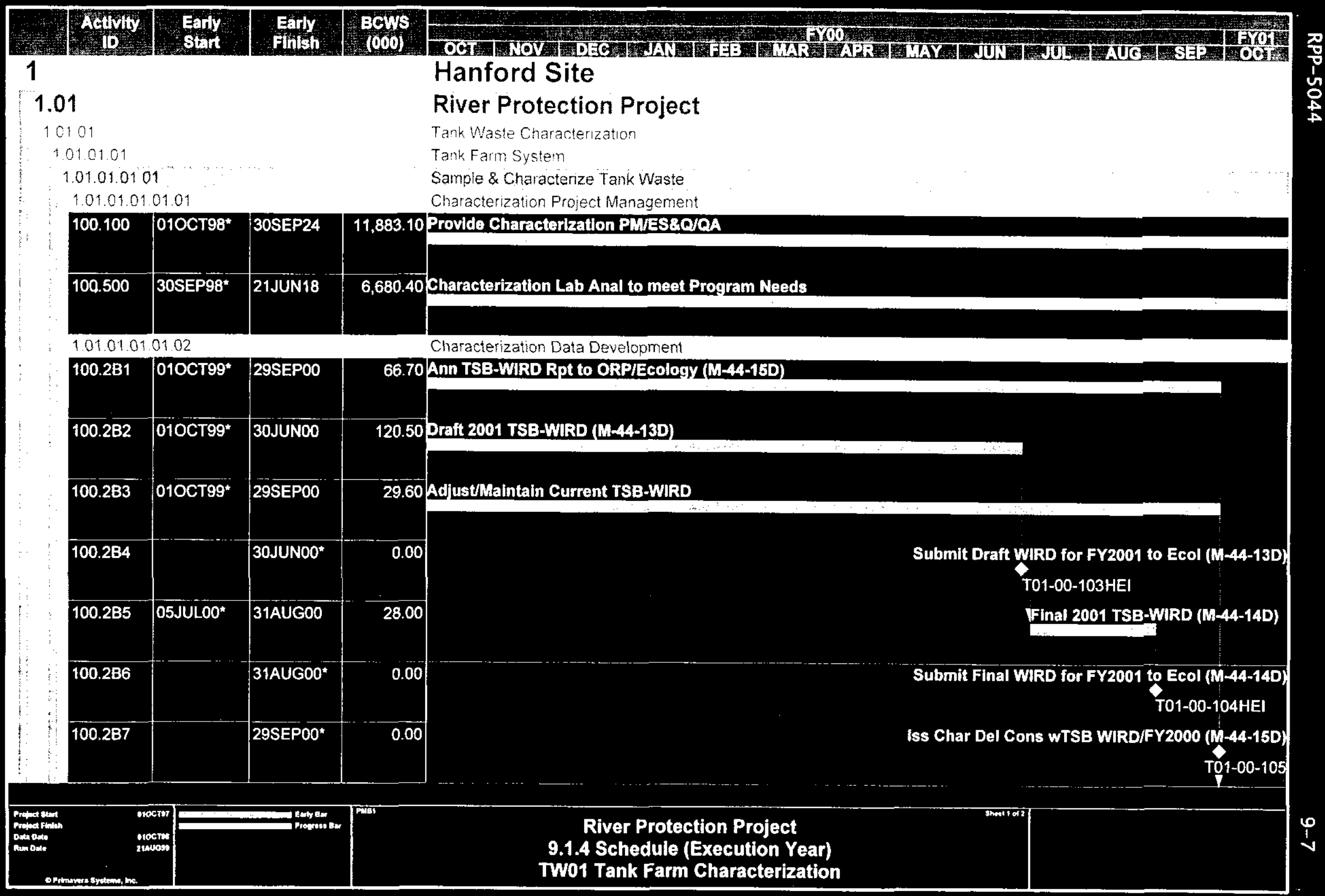




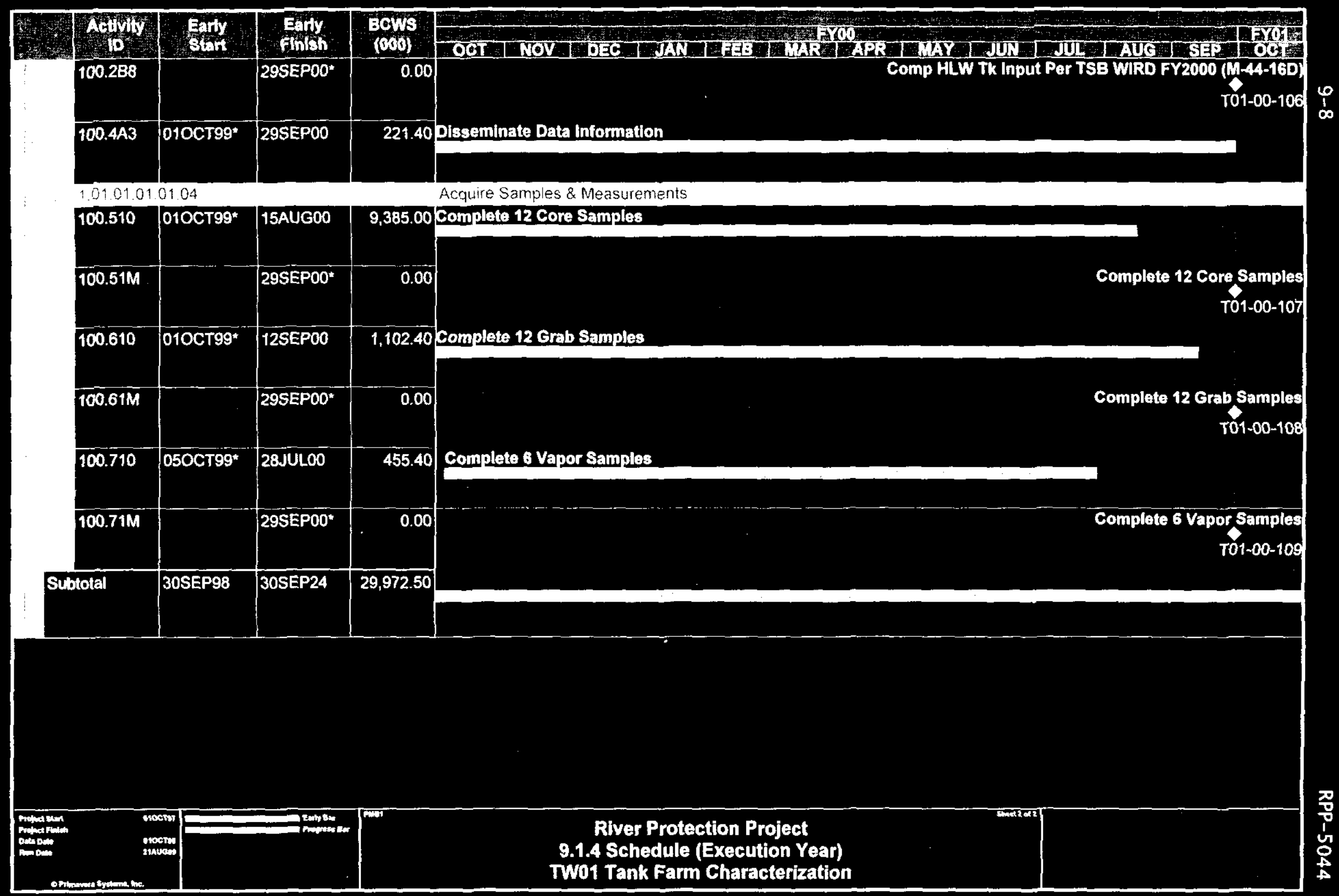




\subsubsection{Milestone Log (Execution Year)}

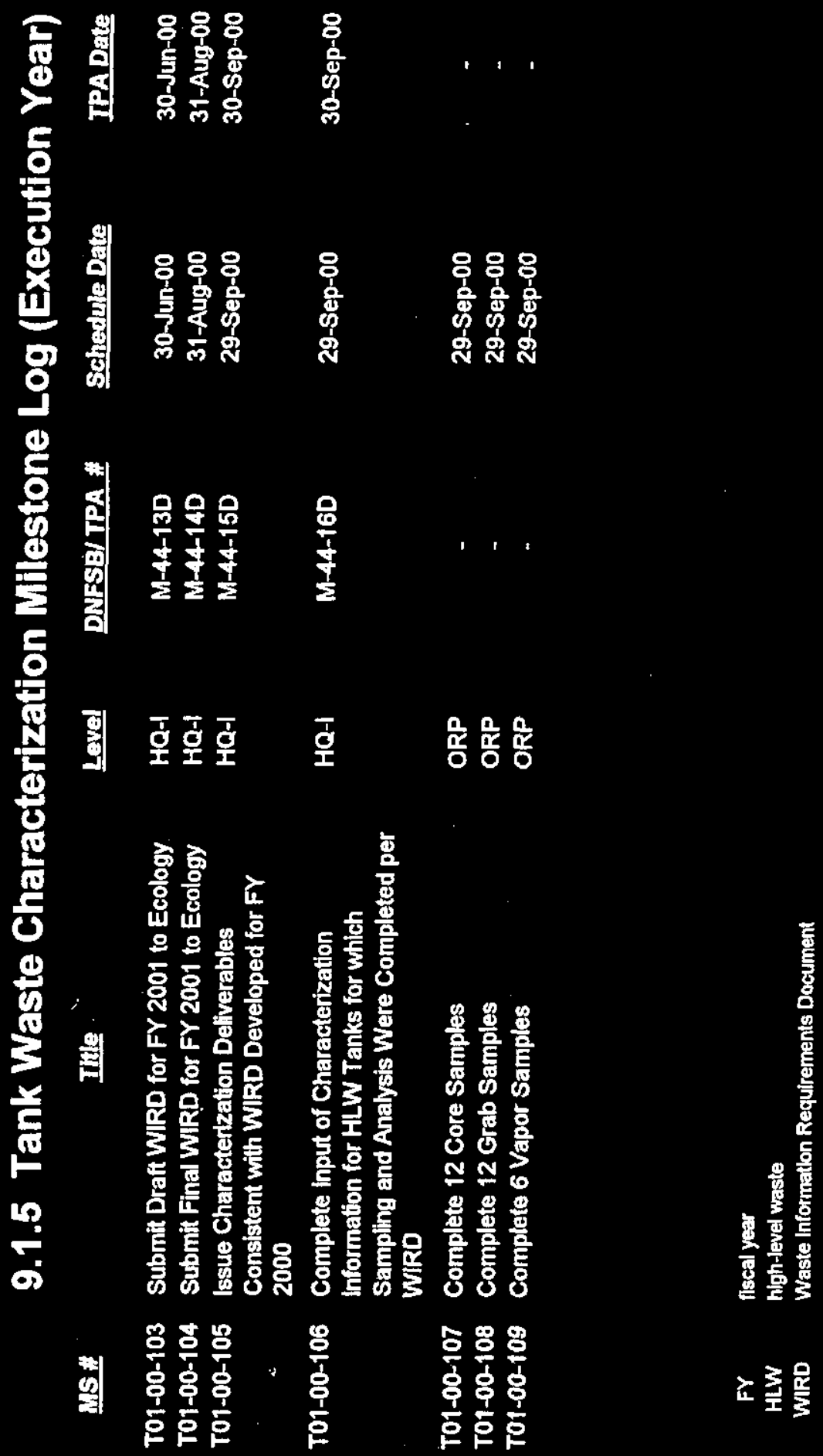


RPP-5044

9-10

This page intentionally left blank 


\subsection{TANK SAFETY ISSUE RESOLUTION (TW02)}

\subsubsection{Mission Statement}

This project is designed to provide an adequate, comprehensive, and reliable safety basis for the RPP to manage and store waste. This will be accomplished by developing and maintaining an integrated Authorization Basis and by resolving outstanding safety issues to ensure safe storage of waste.

The Tank Safety Issue Resolution Project was established to address hazards associated with storing radioactive mixed waste in the large underground storage tanks at the Hanford Site. Safety issues have been raised for flammable gas and organic complexants stored in single-shell tanks, double-shell tanks, and ancillary facilities. In response to Public Law 101-510, Section 3137, "Safety Measures for Waste Tanks at Hanford Nuclear Reservation," tanks for which the concern is highest have been placed on the Watch List. This project develops the technical basis for closing unreviewed safety questions (USQ), resolving the safety issues, and removing all tanks from the Watch List. It also supports upgrades to the Final Safety Analysis Report (FSAR), which is the authorization basis for safe operations of the tank farms and continued safe storage of the tank contents. 
RPP-5044

9-12

9.2.2 Life-Cycle Costs by Fiscal Year

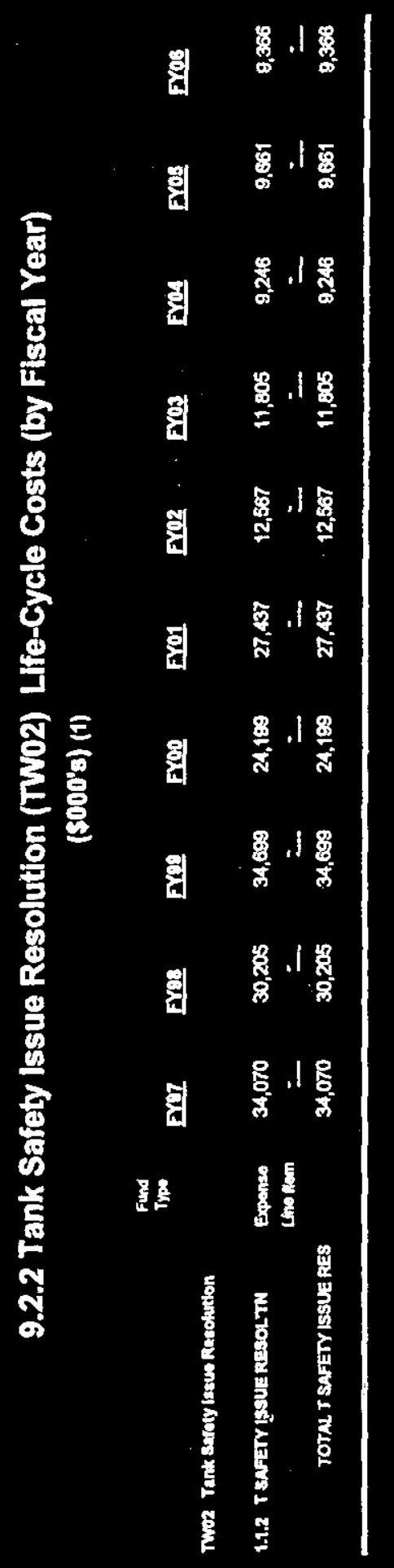




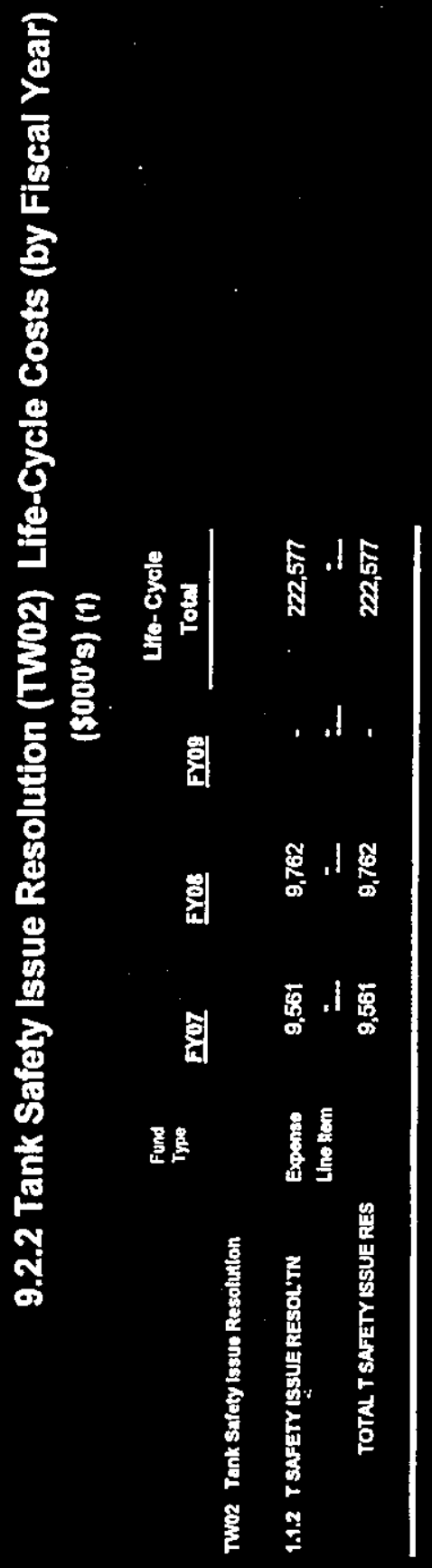


RPP-5044

9-14

\subsubsection{Budget Profile by Month (Execution Year)}

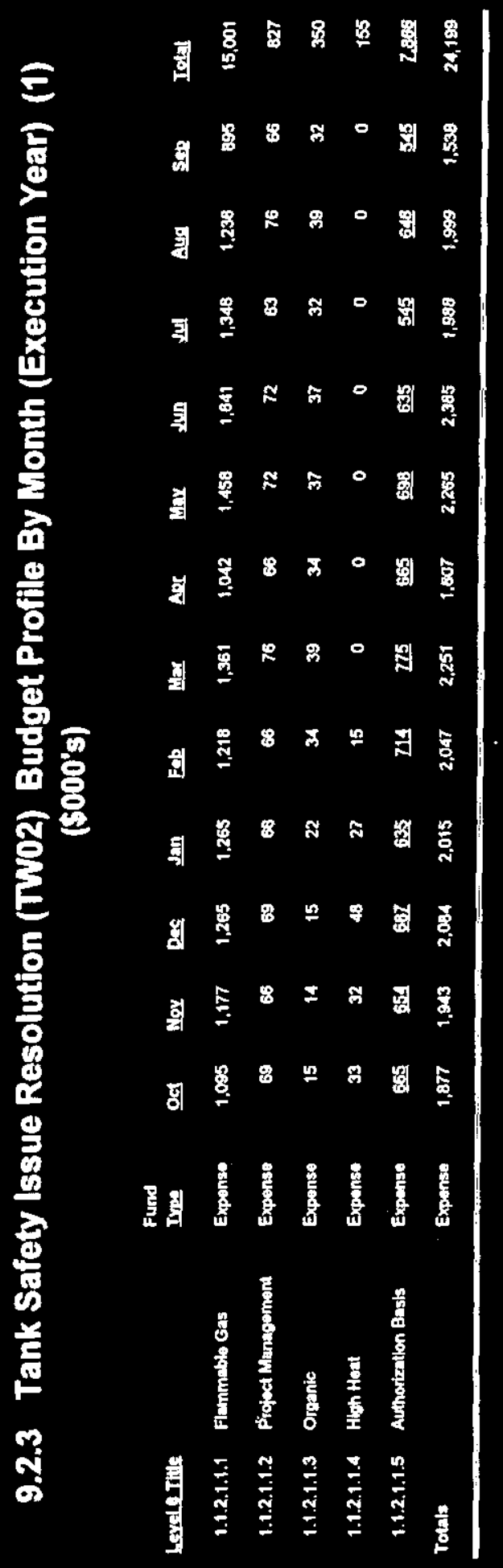




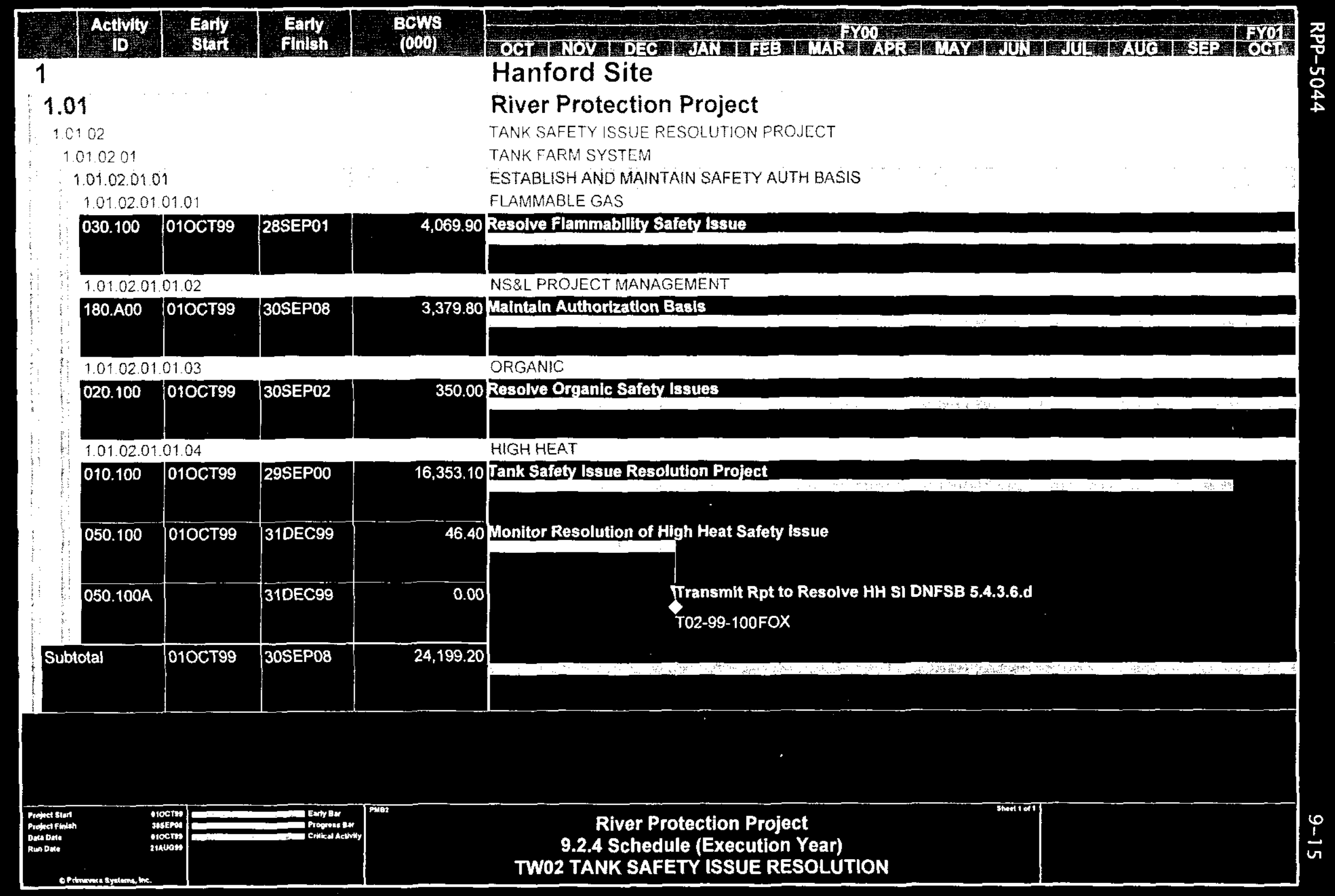


RPP-5044

9-16

9.2.5 Milestone Log (Execution Year)
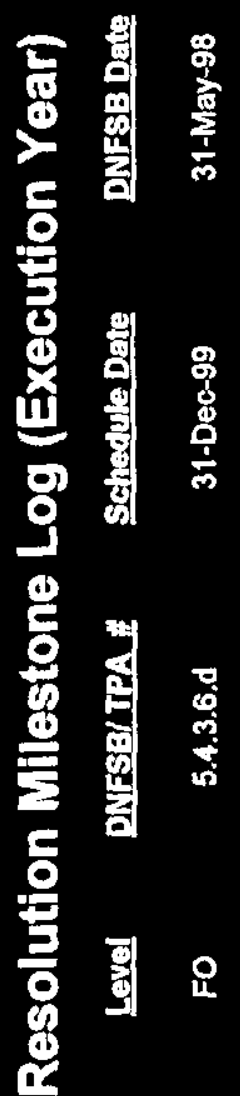

$\frac{0}{4}$
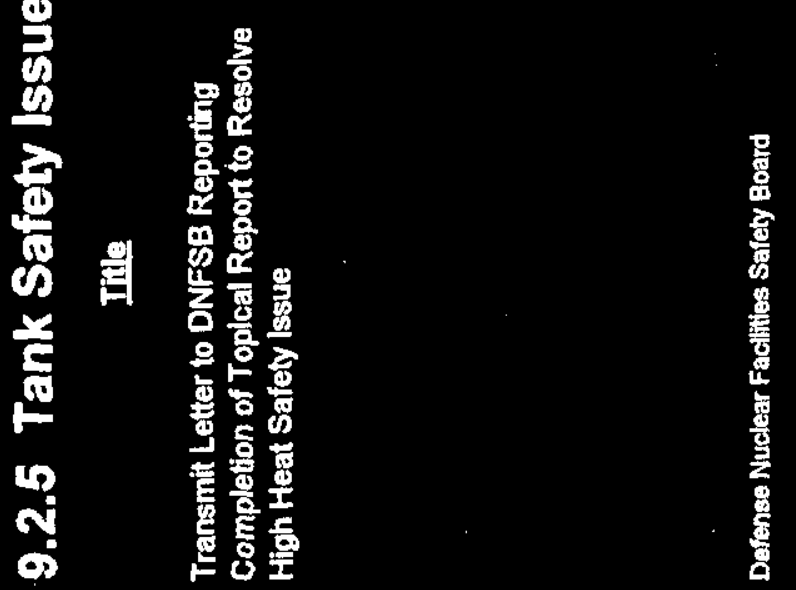

불 $\frac{8}{8}$

总 


\subsection{TANK FARM OPERATIONS (TW03)}

\subsubsection{Mission Statement}

Tank Farms Operations operates and maintains the RPP mission-required tank farm systems, structures, and components (SSC) in a safe, reliable, and operable condition to meet mission requirements. The technical approach to Tank Farms Operations is to conduct all activities pertaining to the operation of a permitted treatment, storage, and disposal (TSD) facility within the boundary of the current Authorization Basis and in a manner that ensures compliance with all applicable Federal, State, and local laws and regulations. (Ensuring a safe working environment for all employees and support groups also is a top priority.) Tank Farm Operations performs all operations support functions required for routine surveillance, operation, and maintenance of the 200 East Area and 200 West Area tank farms. These functions include the following:

- Performing preventive and corrective maintenance (routine and non-routine)

- Performing waste transfers to feed tanks in support of waste concentration operations

- Conducting radiological health physics activities

- Conducting routine surveillance monitoring

- Conducting industrial hygiene and safety functions

- Performing engineering and analysis (trade studies and analysis capability upgrades)

- Managing and controlling projects and upgrades to facilities and infrastructure

- Enhancing the safety of facility operations and preparing the facilities for eventual turnover to the Retrieval Project for closure.

In addition, Tank Farms Operations has the mandate to pump interstitial liquid from the aging, single-shell tanks in the 200 Area Tank Farms and transfer it to the safer, compliant double shell tanks in accordance with the Consent Decree, Tri-Party Agreement milestones, and other schedules as set by DOE. 
9.3.2 Tank Farm Operations (Two3) Life-Cycle Costs (by Fiscal Year)

$(500018)(1)$

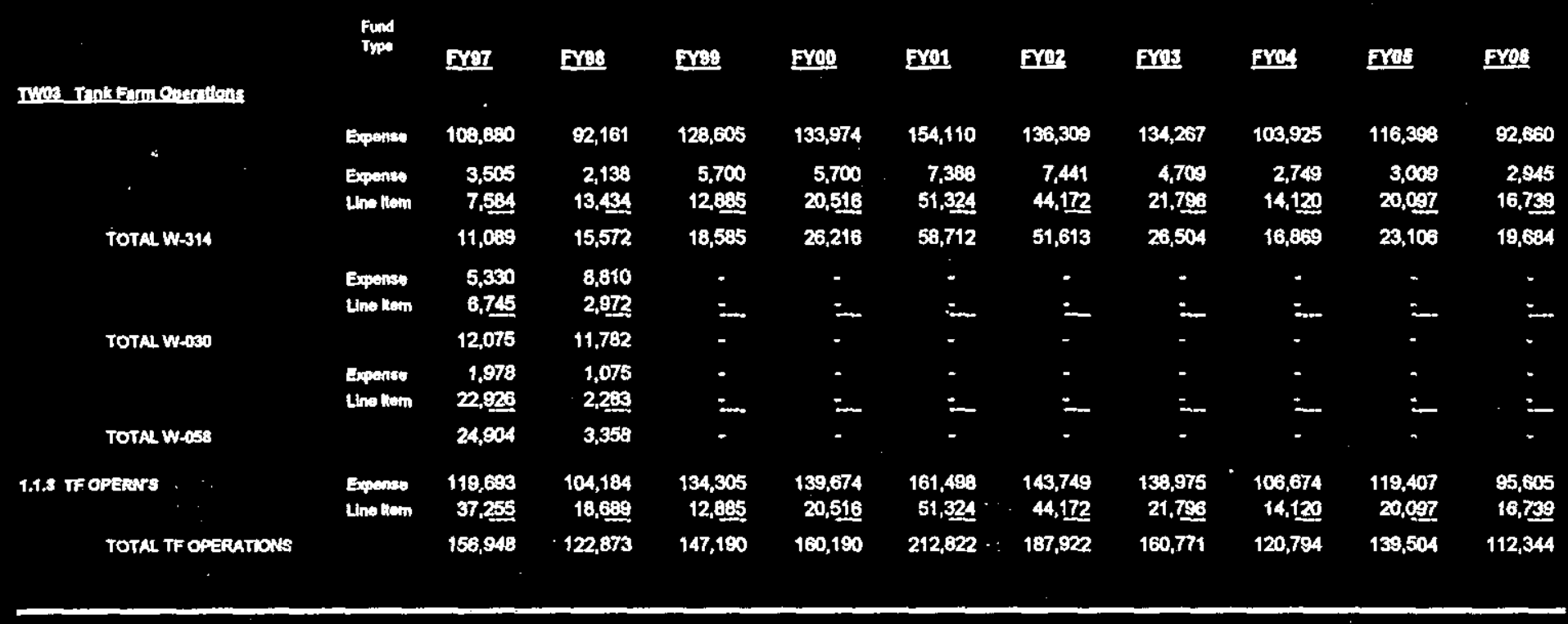




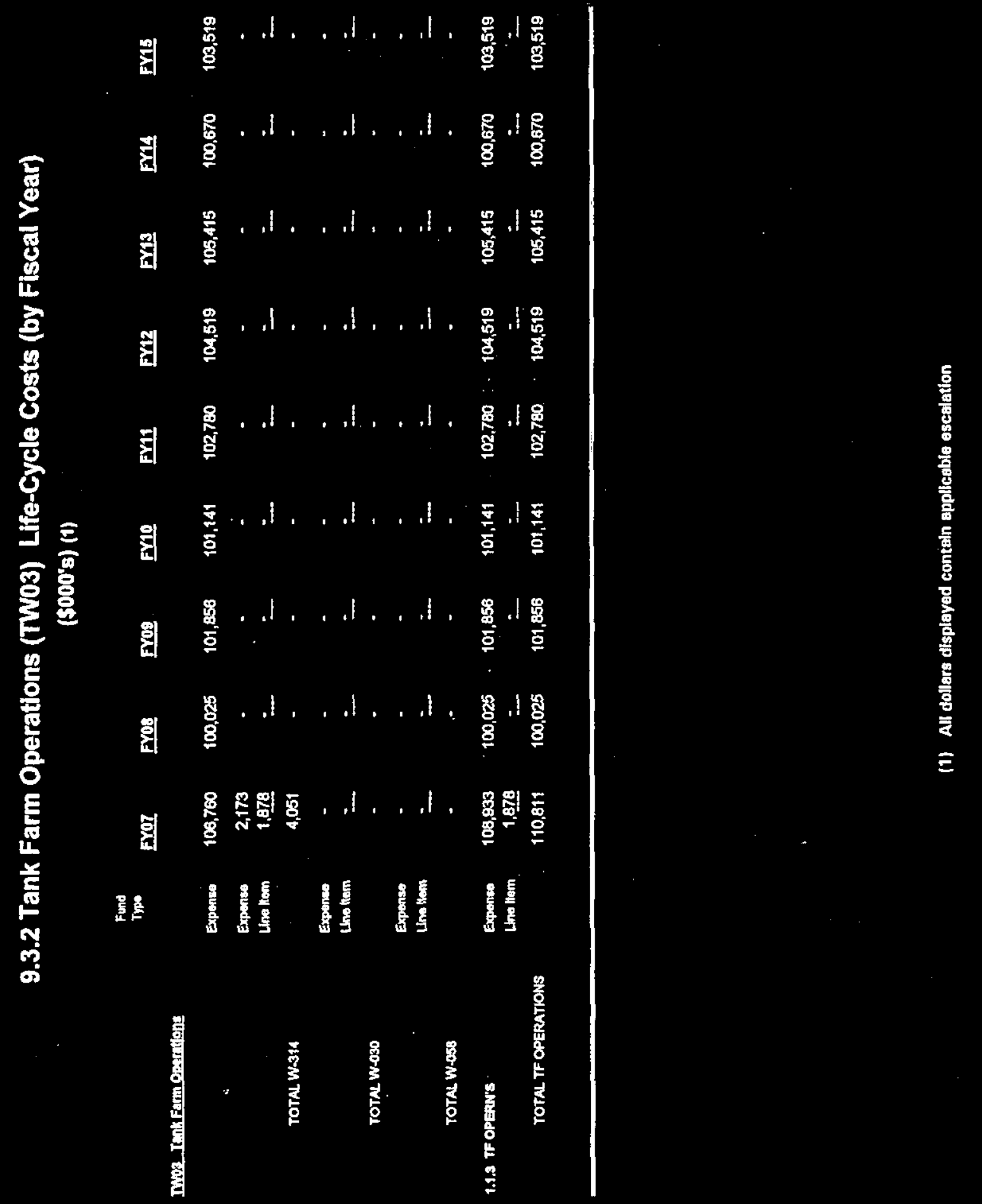




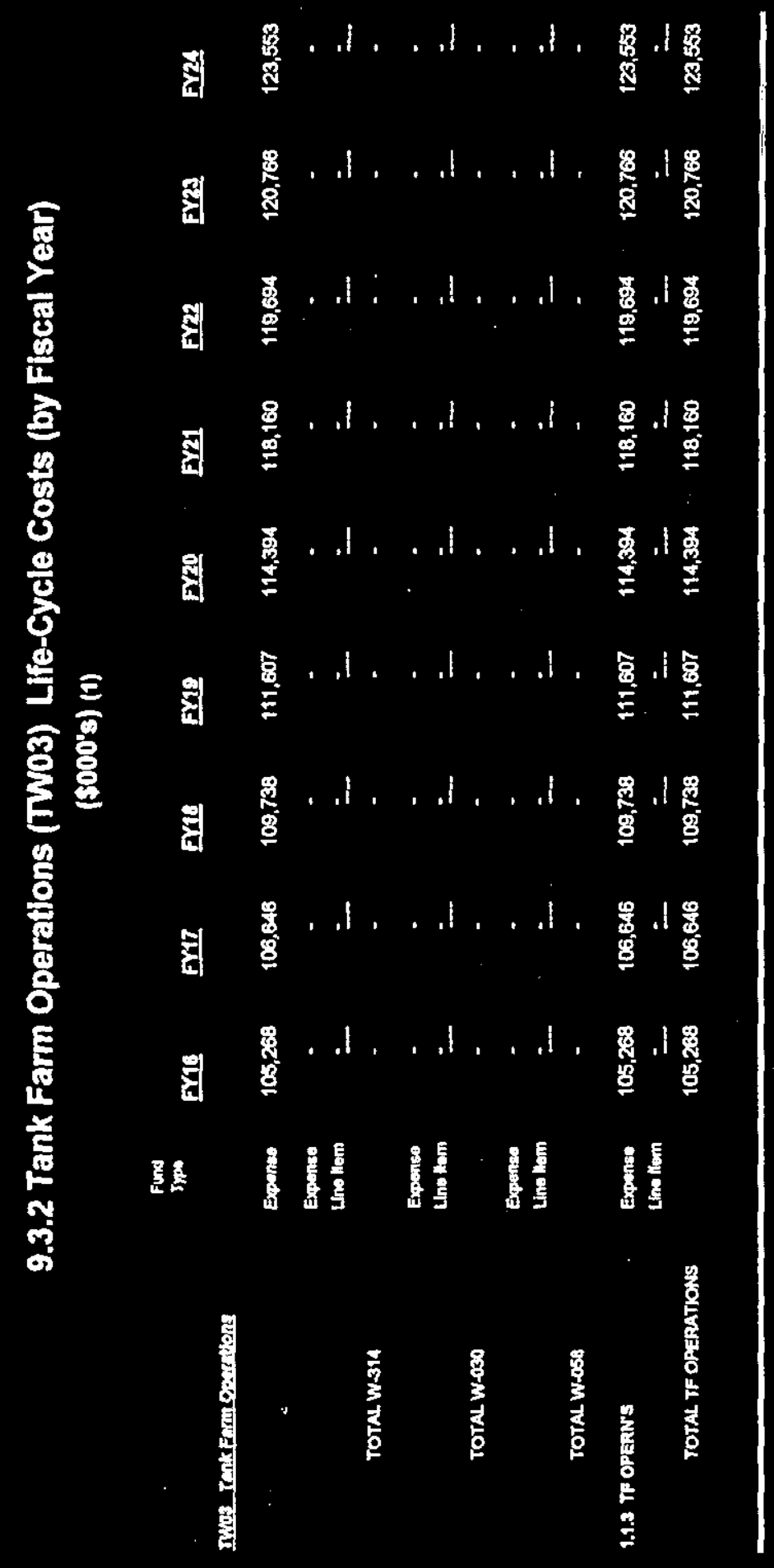




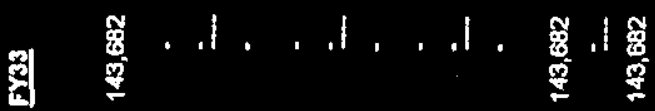

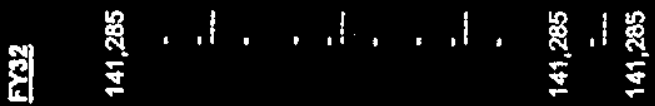

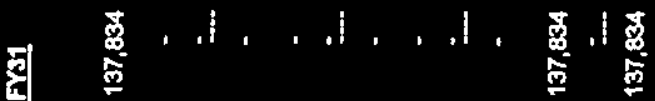

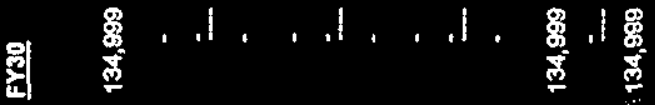

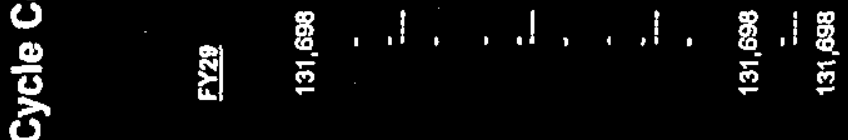

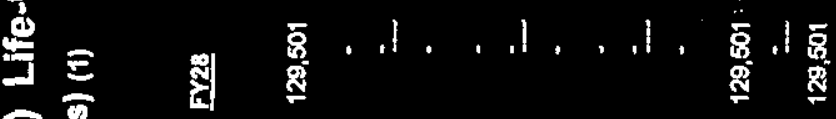

$$
\begin{aligned}
& \text { E }
\end{aligned}
$$

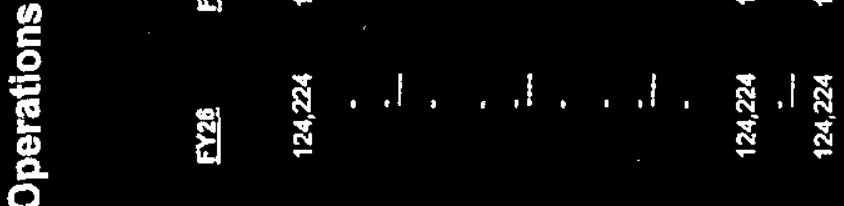

$$
\begin{aligned}
& \text { 产 }
\end{aligned}
$$

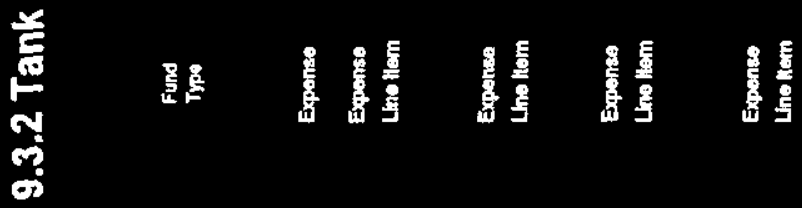

$$
\begin{aligned}
& \text { 몀 }
\end{aligned}
$$

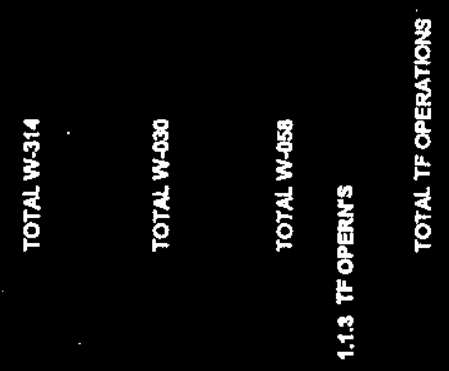


RPP-5044

9-22

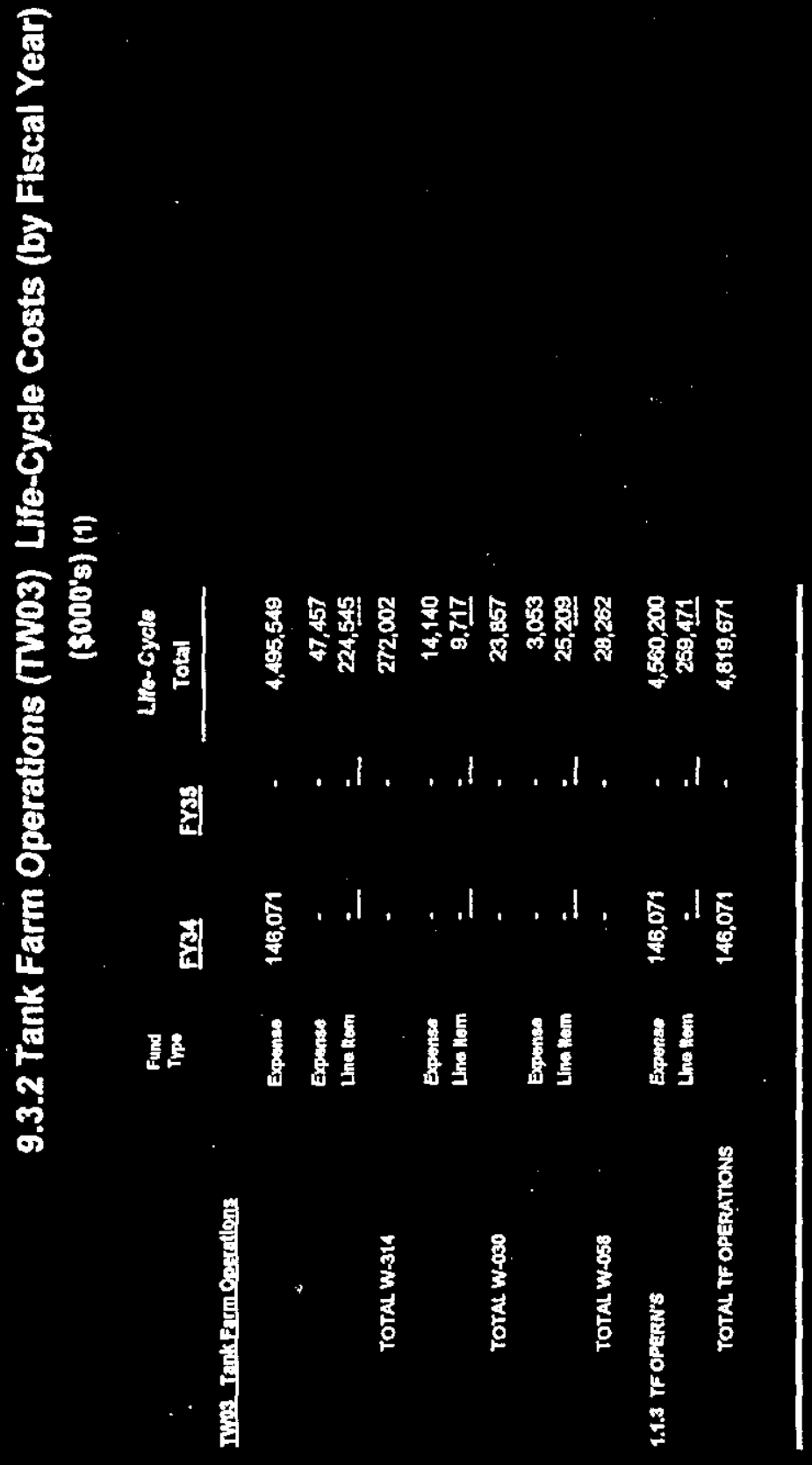




\subsubsection{Budget Profile by Month (Execution Year)}

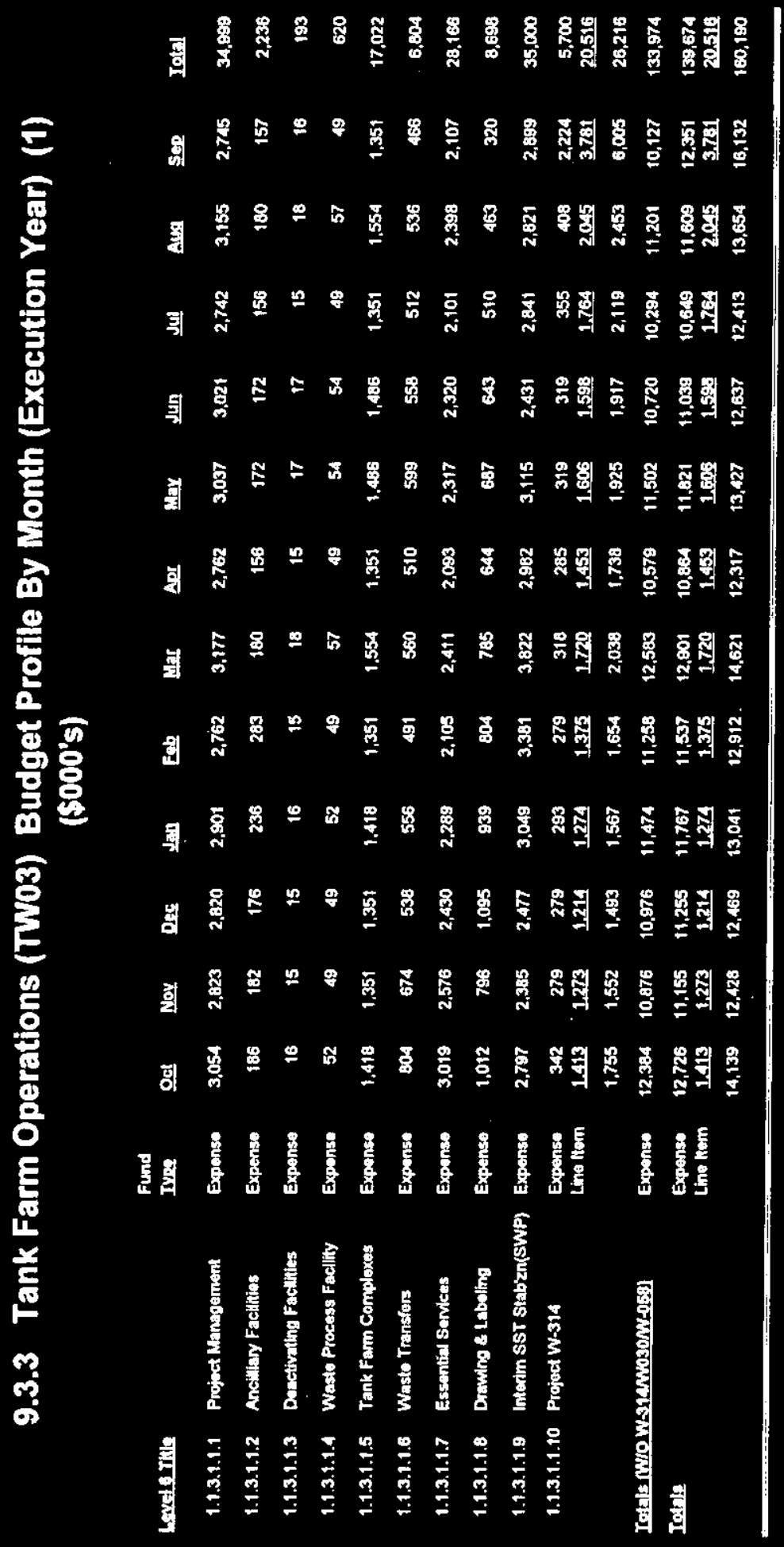




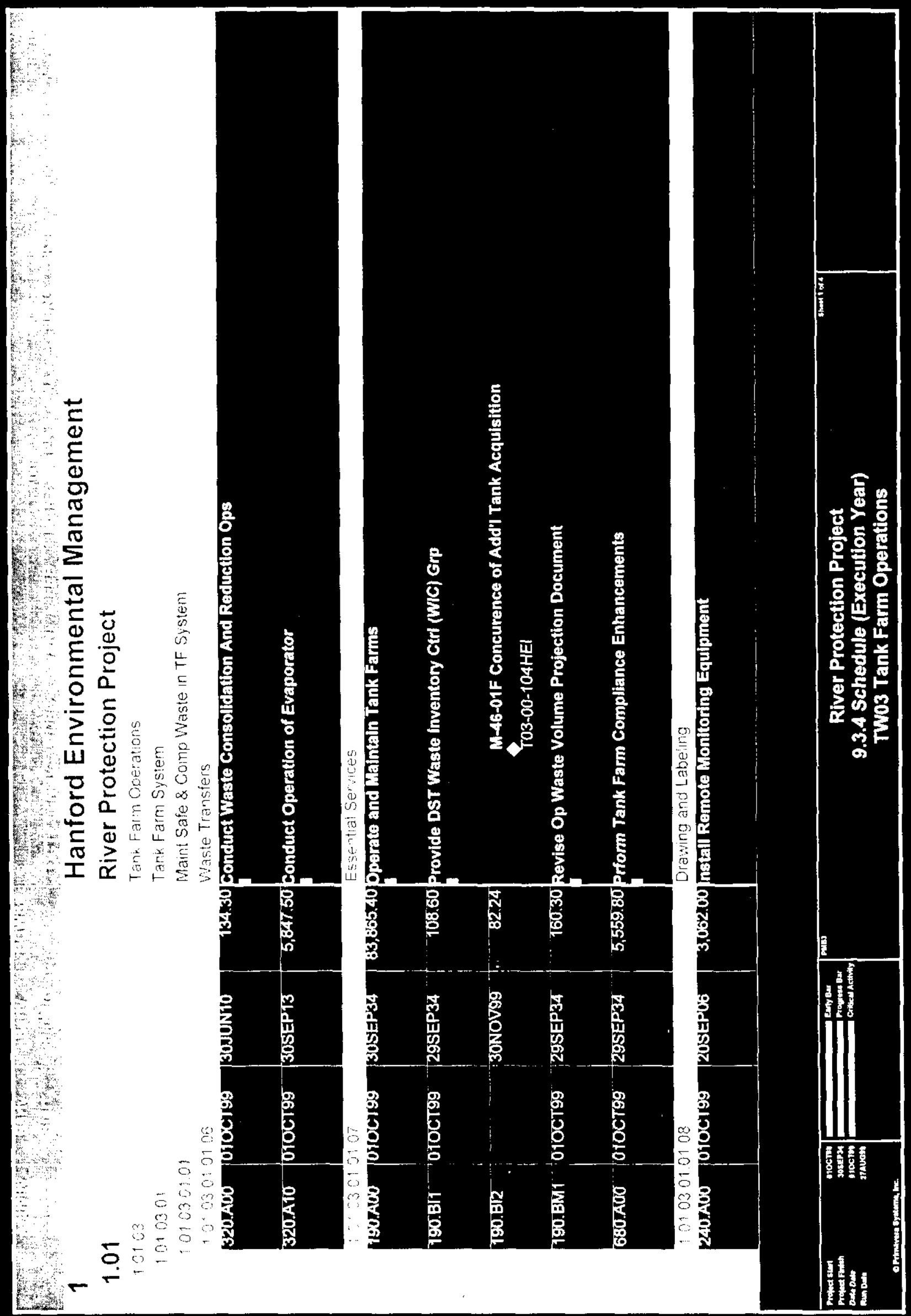




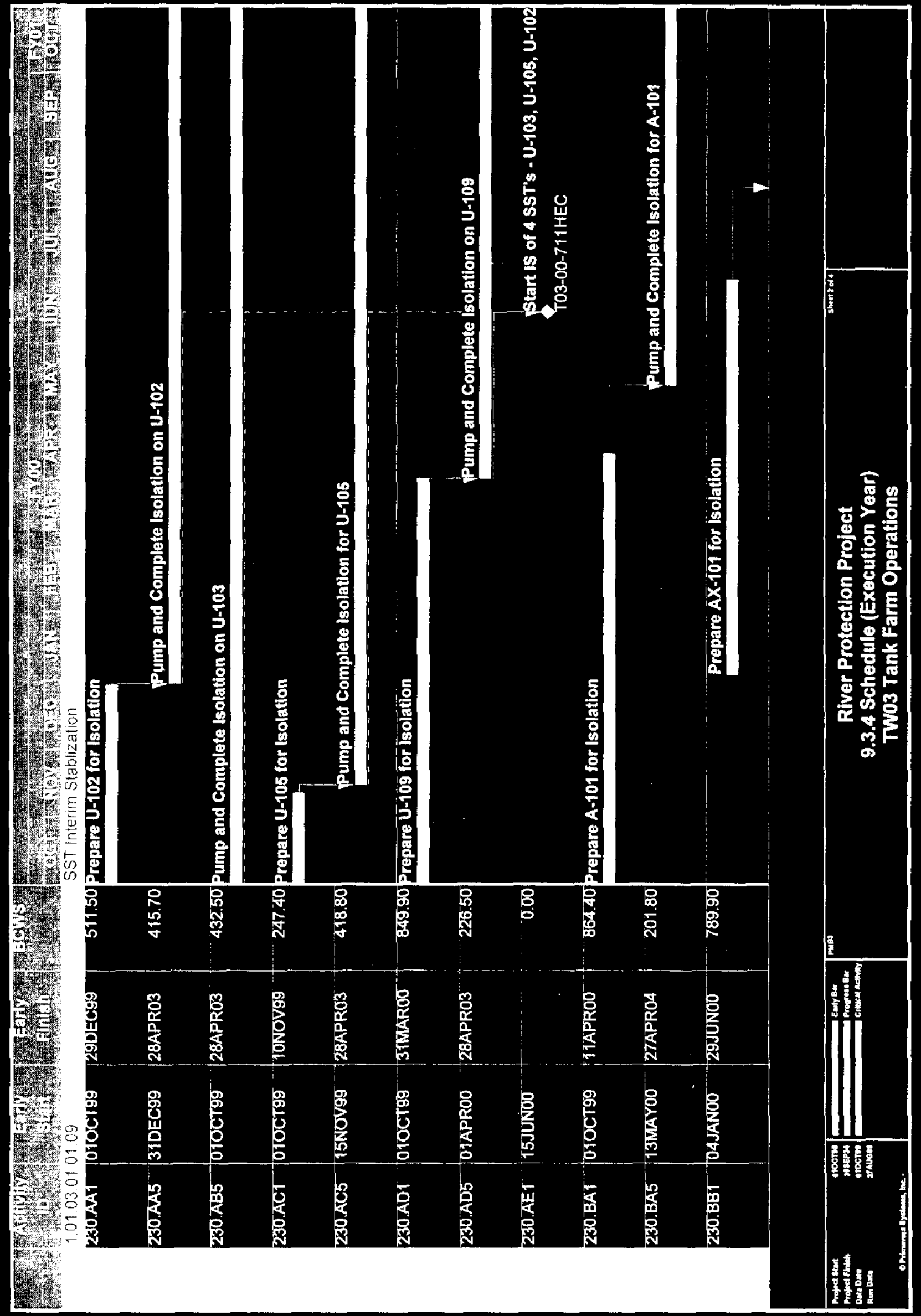




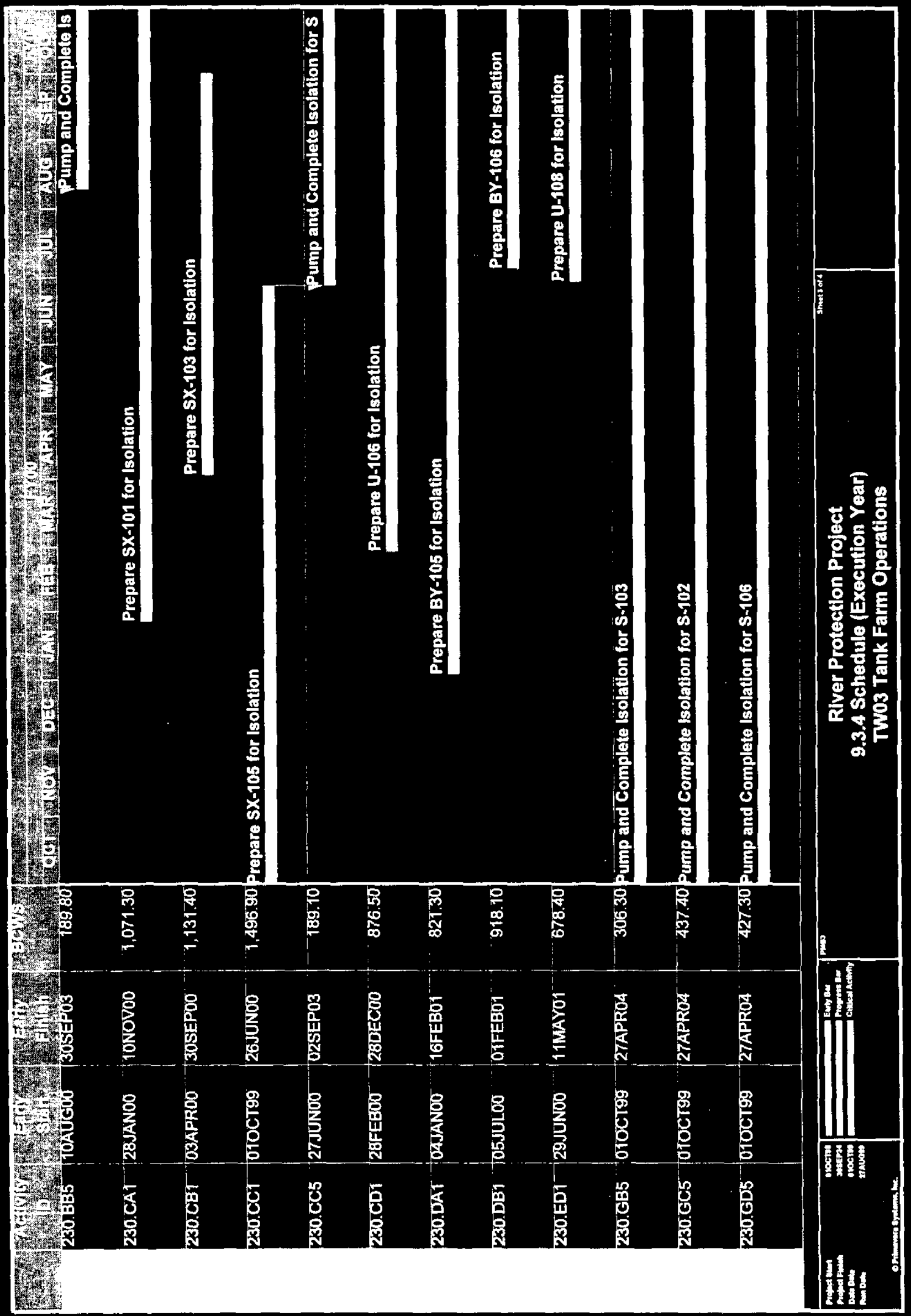




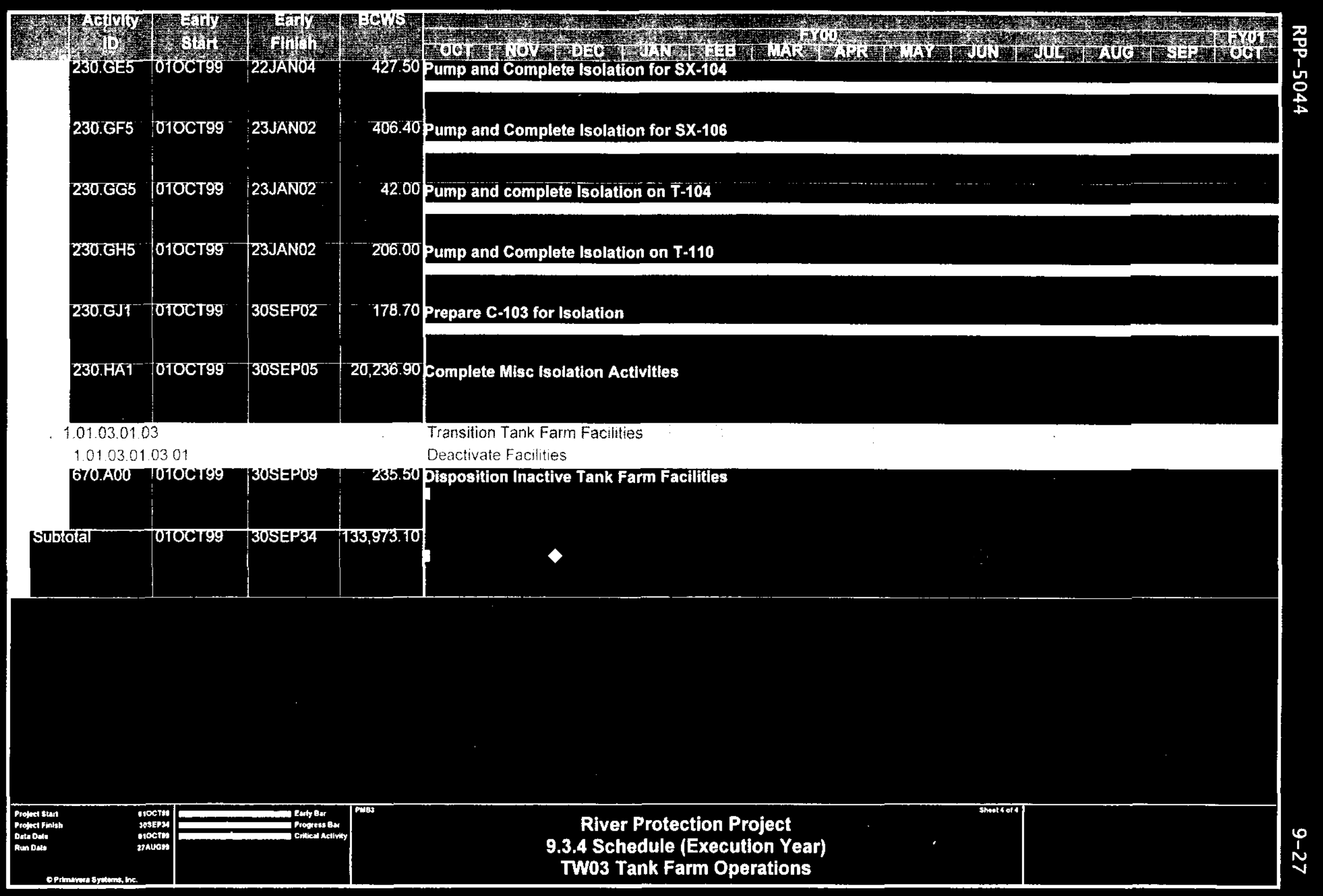




\subsubsection{Milestone Log (Execution Year)}

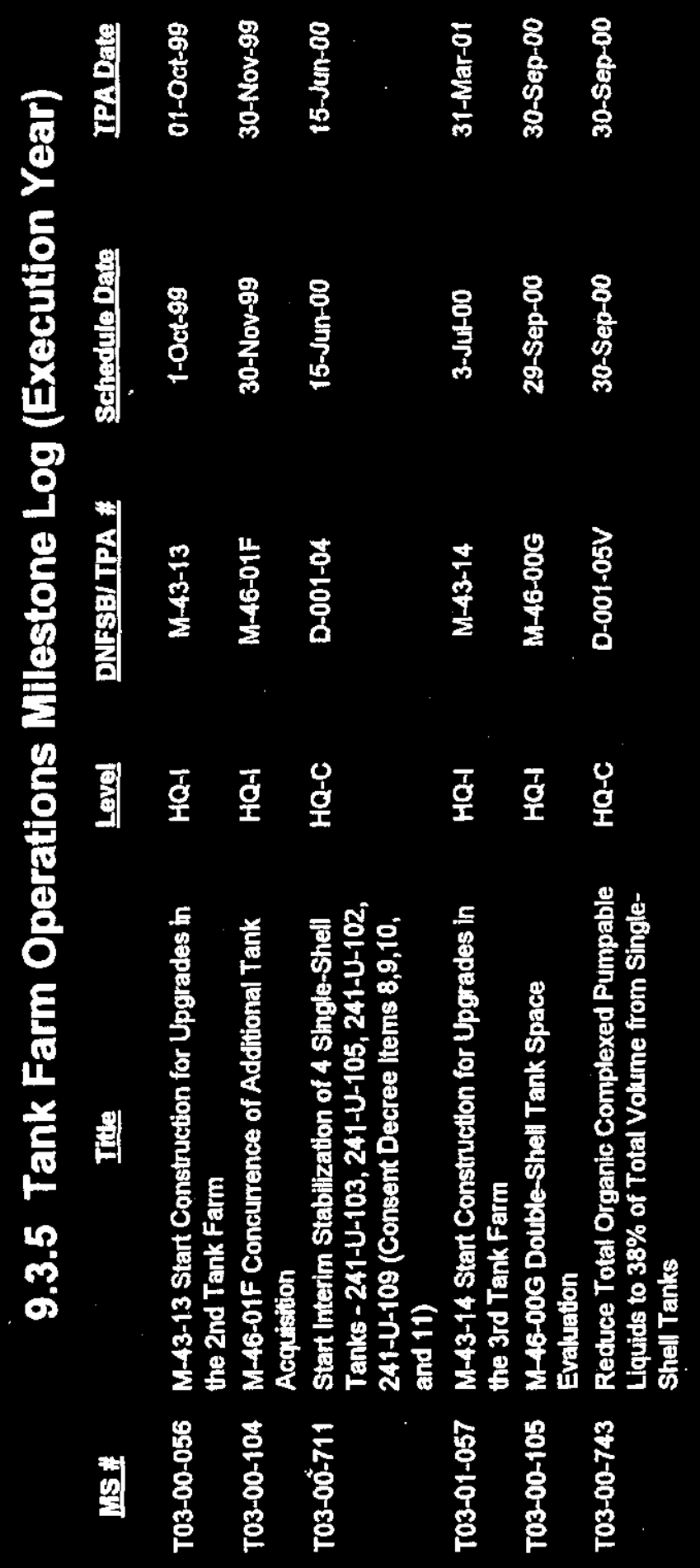




\subsection{RETRIEVAL (TW04)}

\subsubsection{Mission Statement}

The mission of the Retrieval Project is, "in an environmentally sound, safe, secure, and cost-effective manner, to:

1. Retrieve wastes from single-shell tanks, double-shell tanks, and designated miscellaneous underground storage tanks;

2. Provide waste to privatization contractors for processing; and

3. Close those tanks in accordance with regulatory requirements."

The Retrieval Project will establish the functions and requirements and install the equipment needed to deliver the proper waste feed on schedule to the private immobilization contractor for Privatization Phase 1, and transition the waste retrieval and treatment to private contractors for Privatization Phase 2.

The TWRS Environmental Impact Statement Record of Decision calls for retrieving waste from all 149 single-shell tanks, 28 double-shell tanks, and miscellaneous underground storage tanks. Until all waste is retrieved, the double-shell tanks must be used to store and prepare waste retrieved from single-shell and miscellaneous underground storage tanks for waste treatment facilities. 


\subsubsection{Life-Cycle Costs by Fiscal Year}

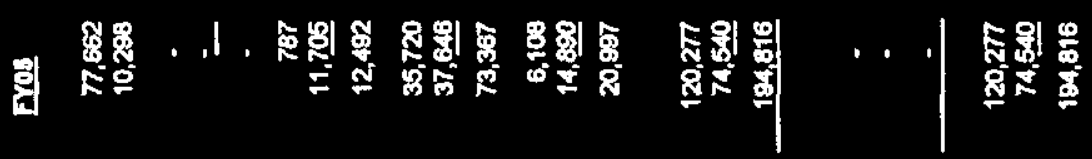

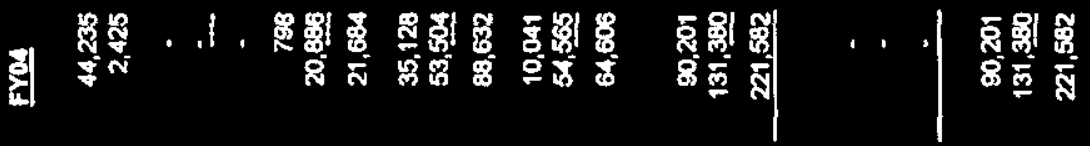

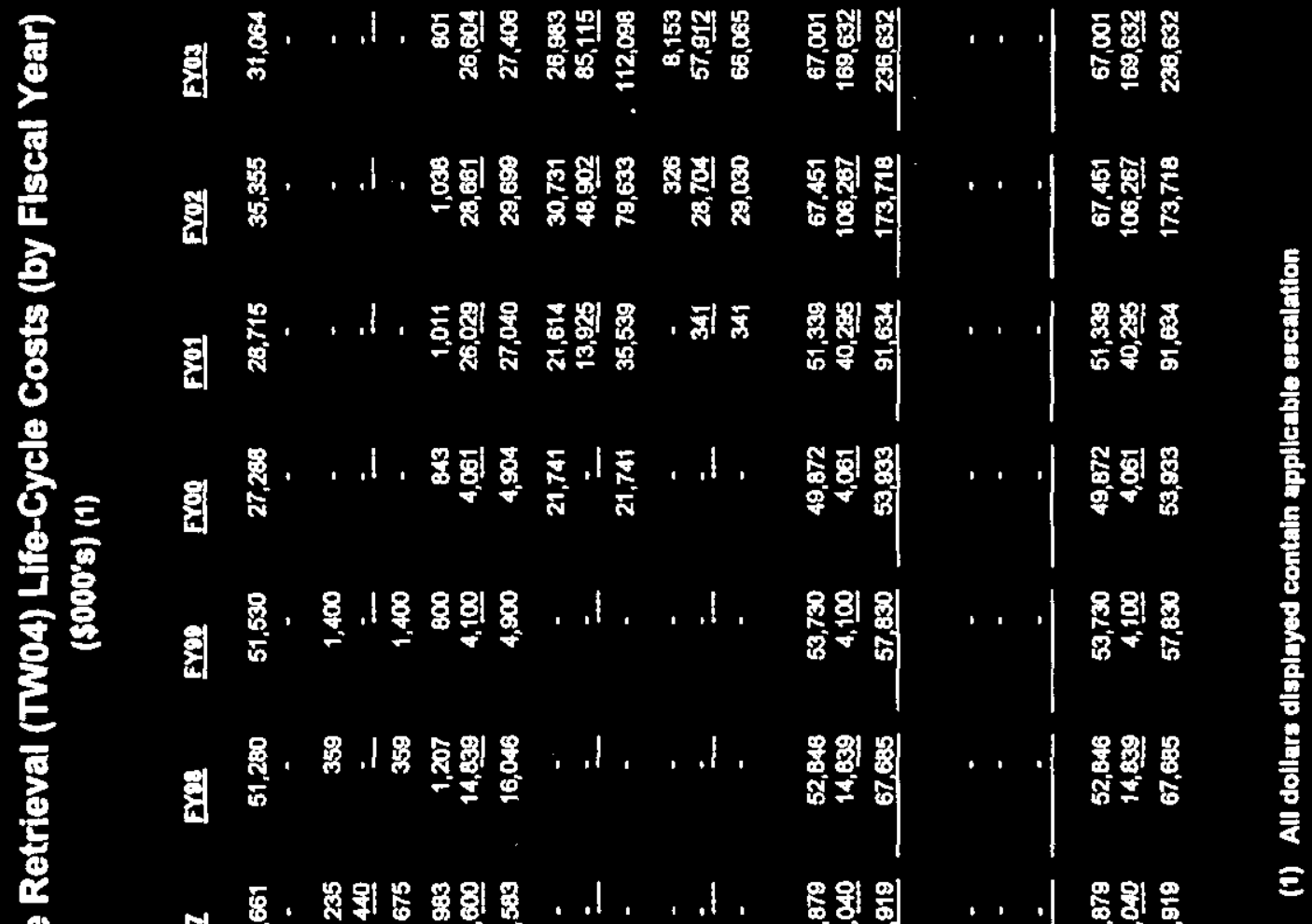

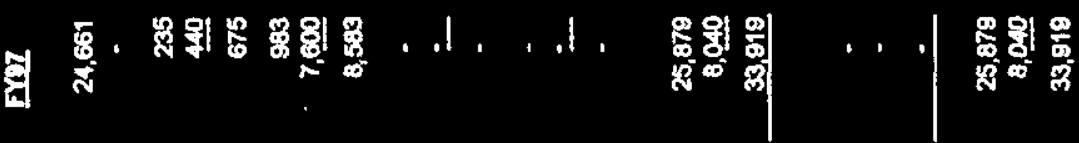

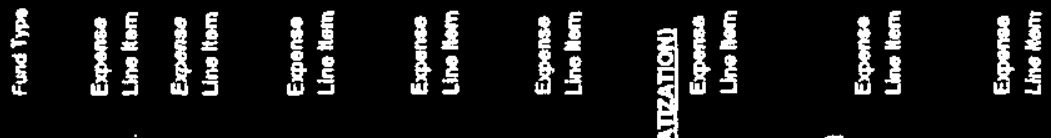

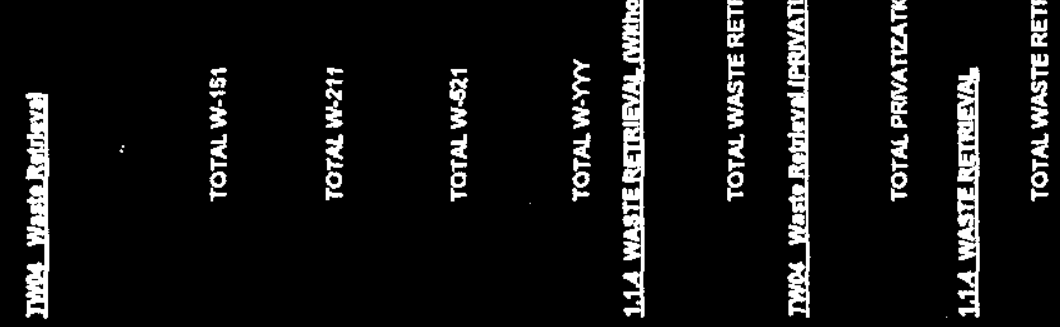




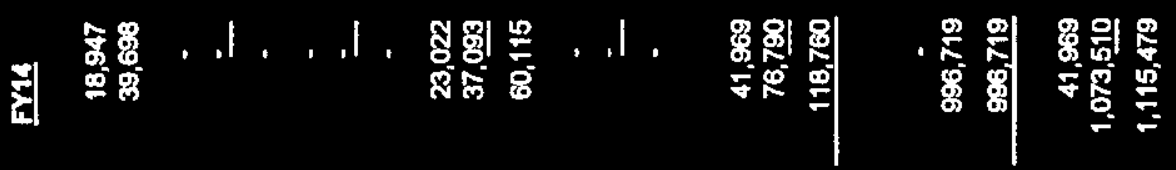

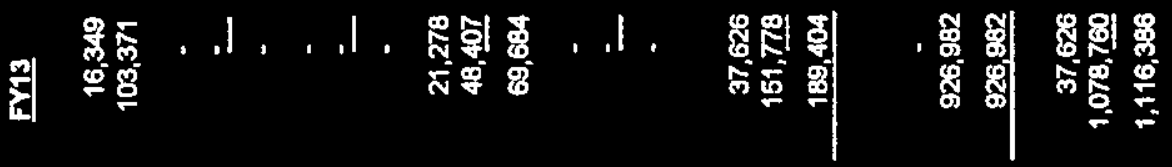

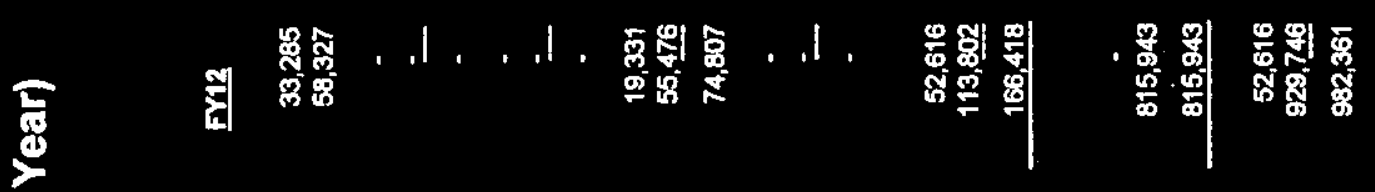

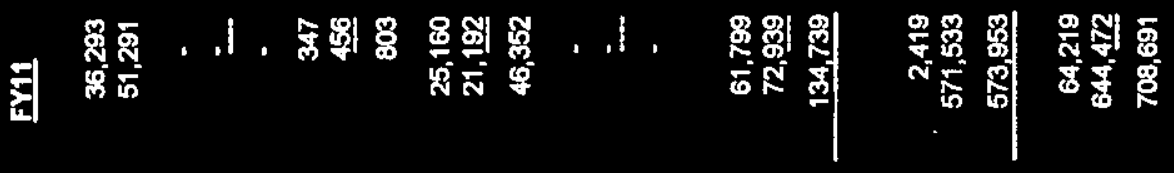

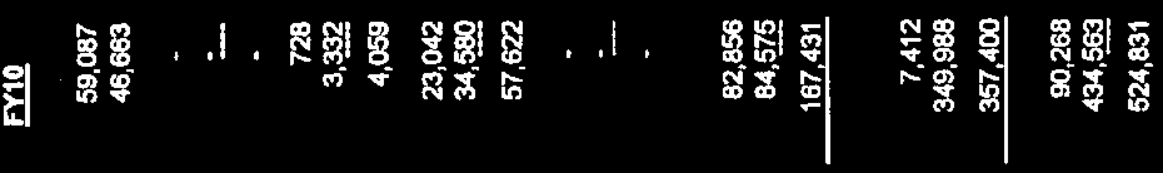

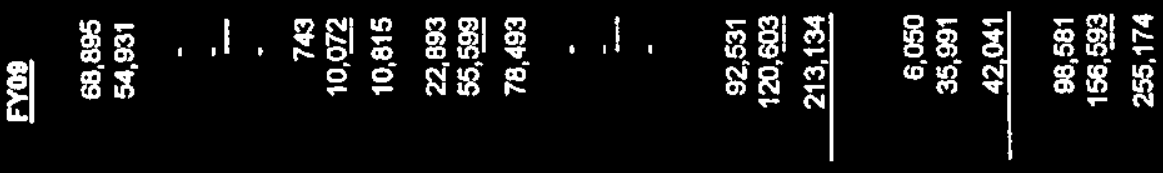

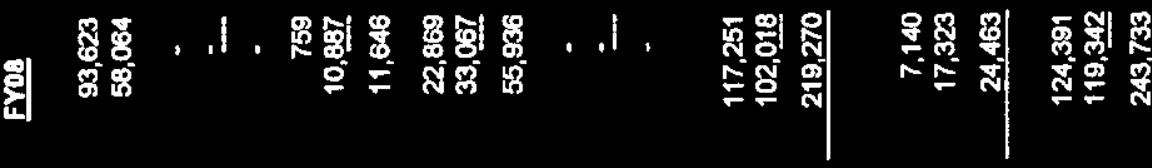

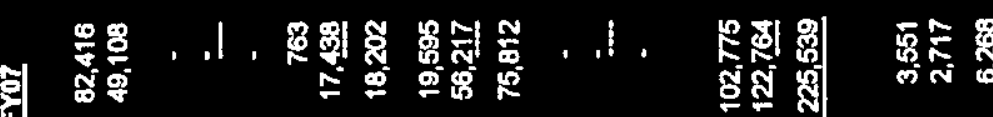

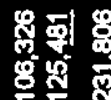

8 要

产

数

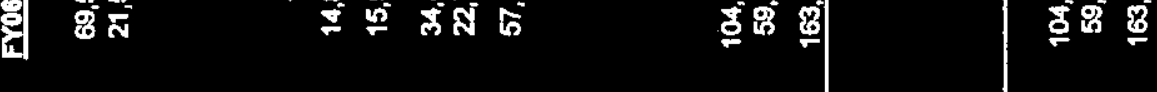

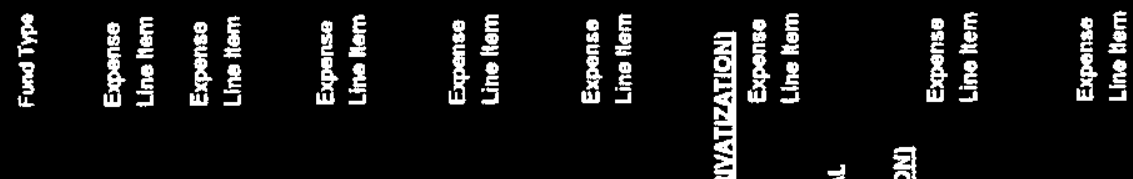

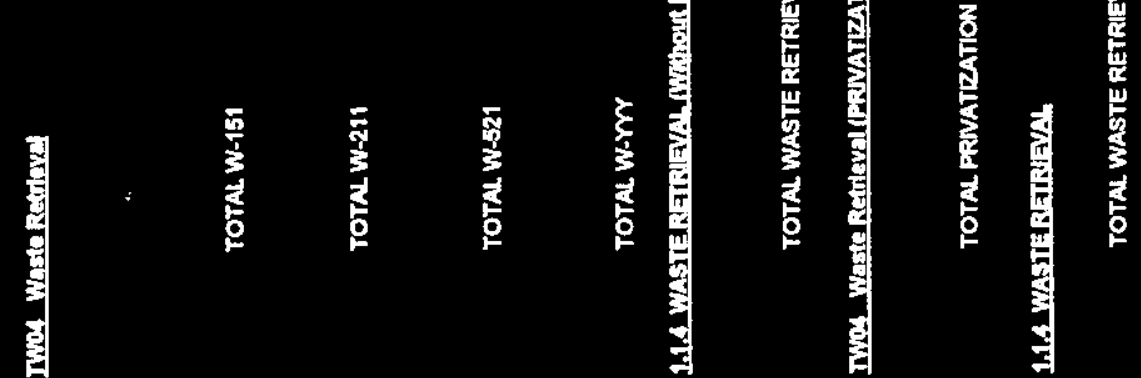




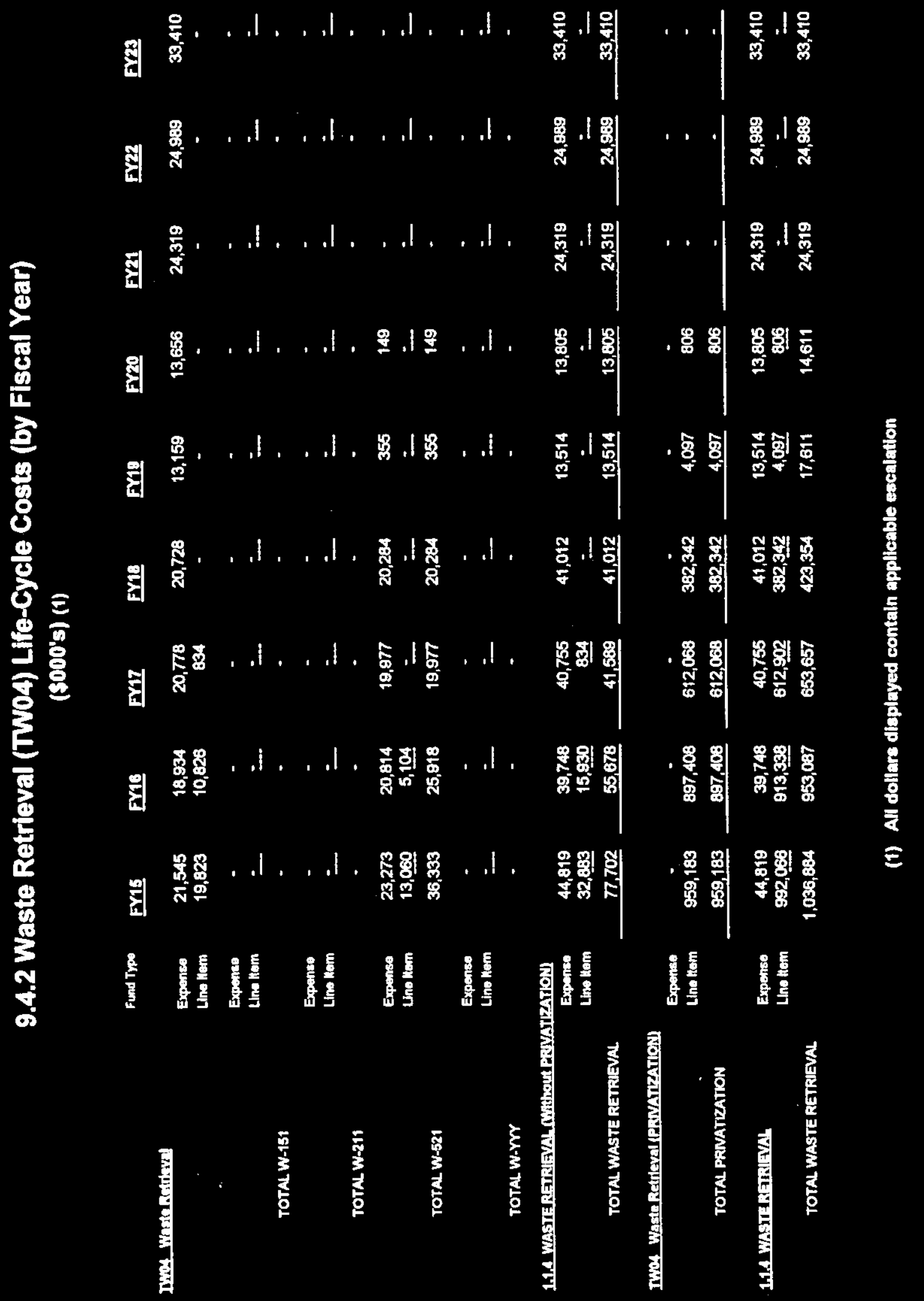




\subsubsection{Waste Retrieval (TW04) Life-Cycle Costs (by Fiscal Year)}

(5000's) (1)

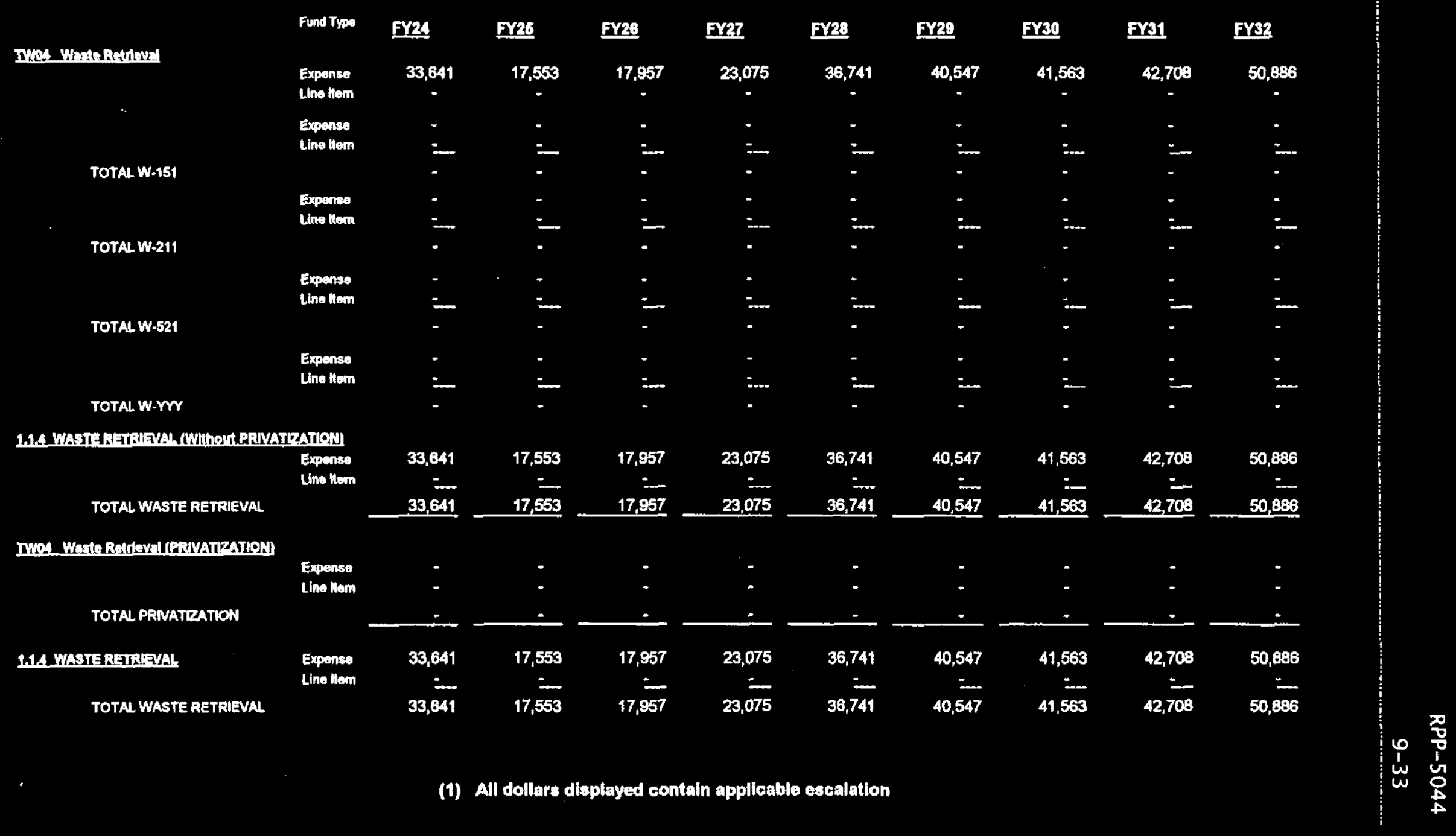




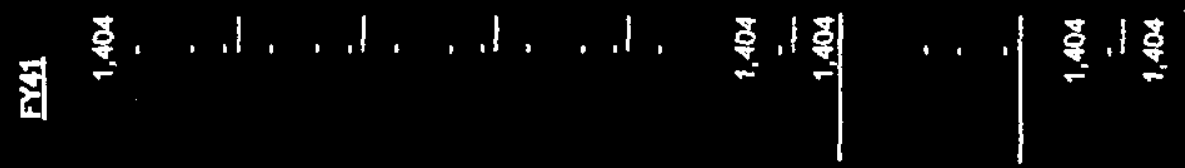

$$
\begin{aligned}
& \text { 武 }
\end{aligned}
$$

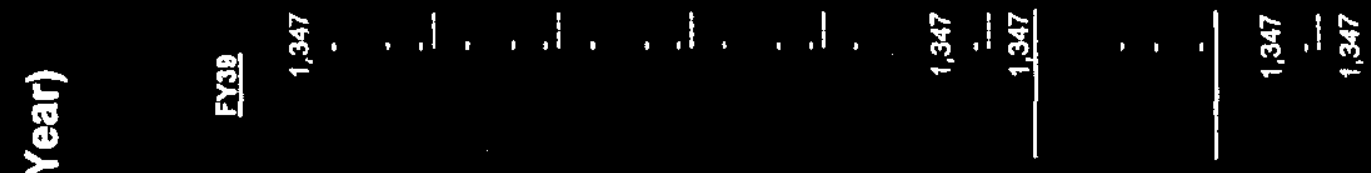

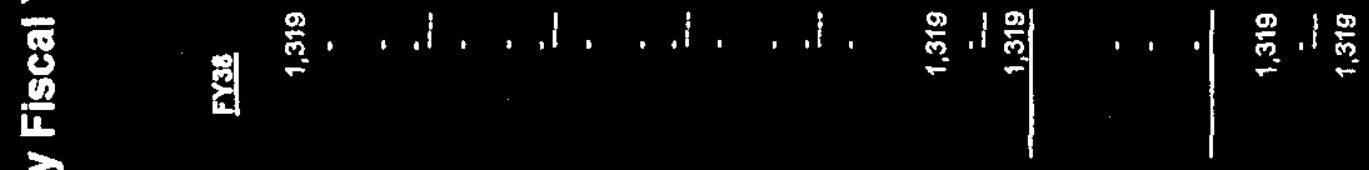

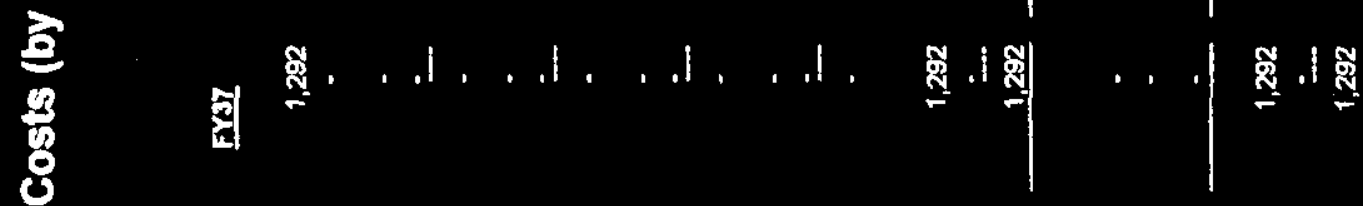

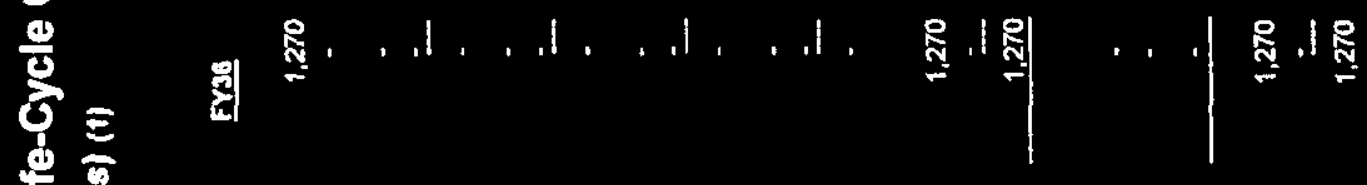

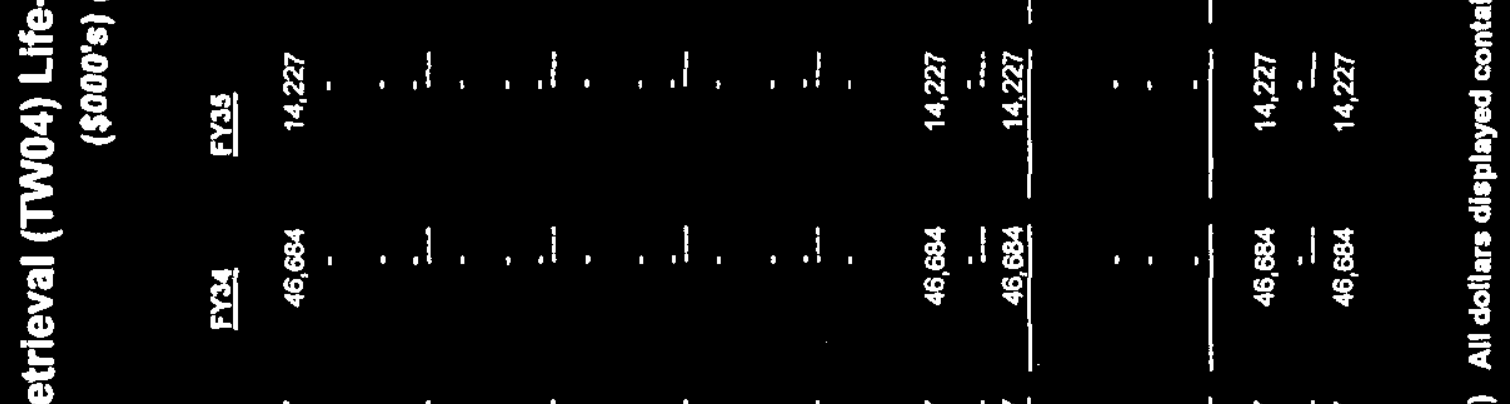

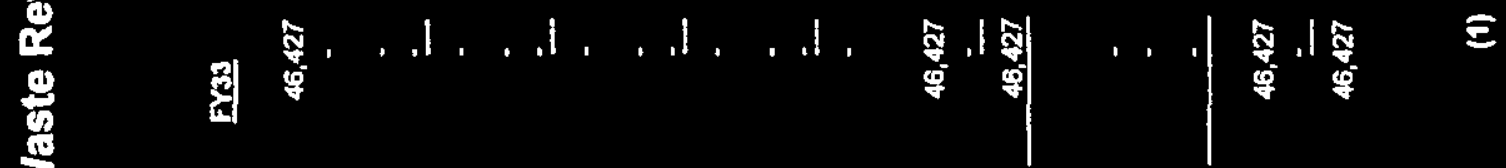

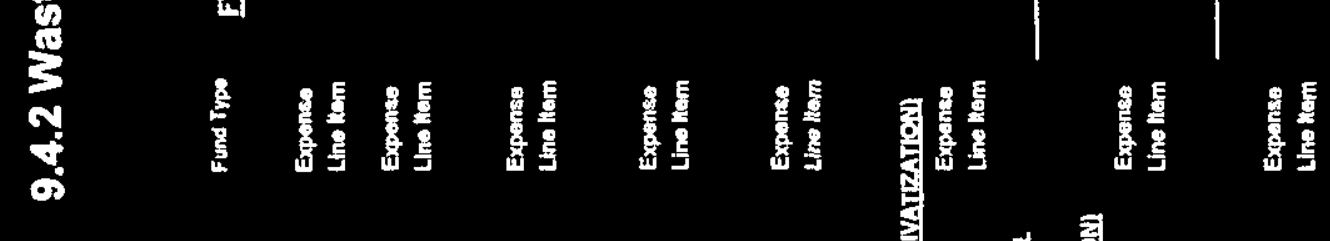

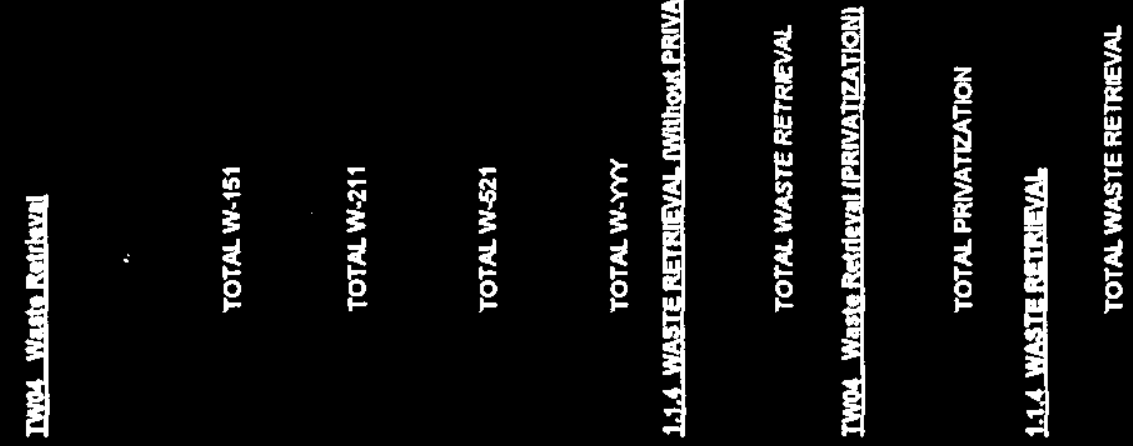




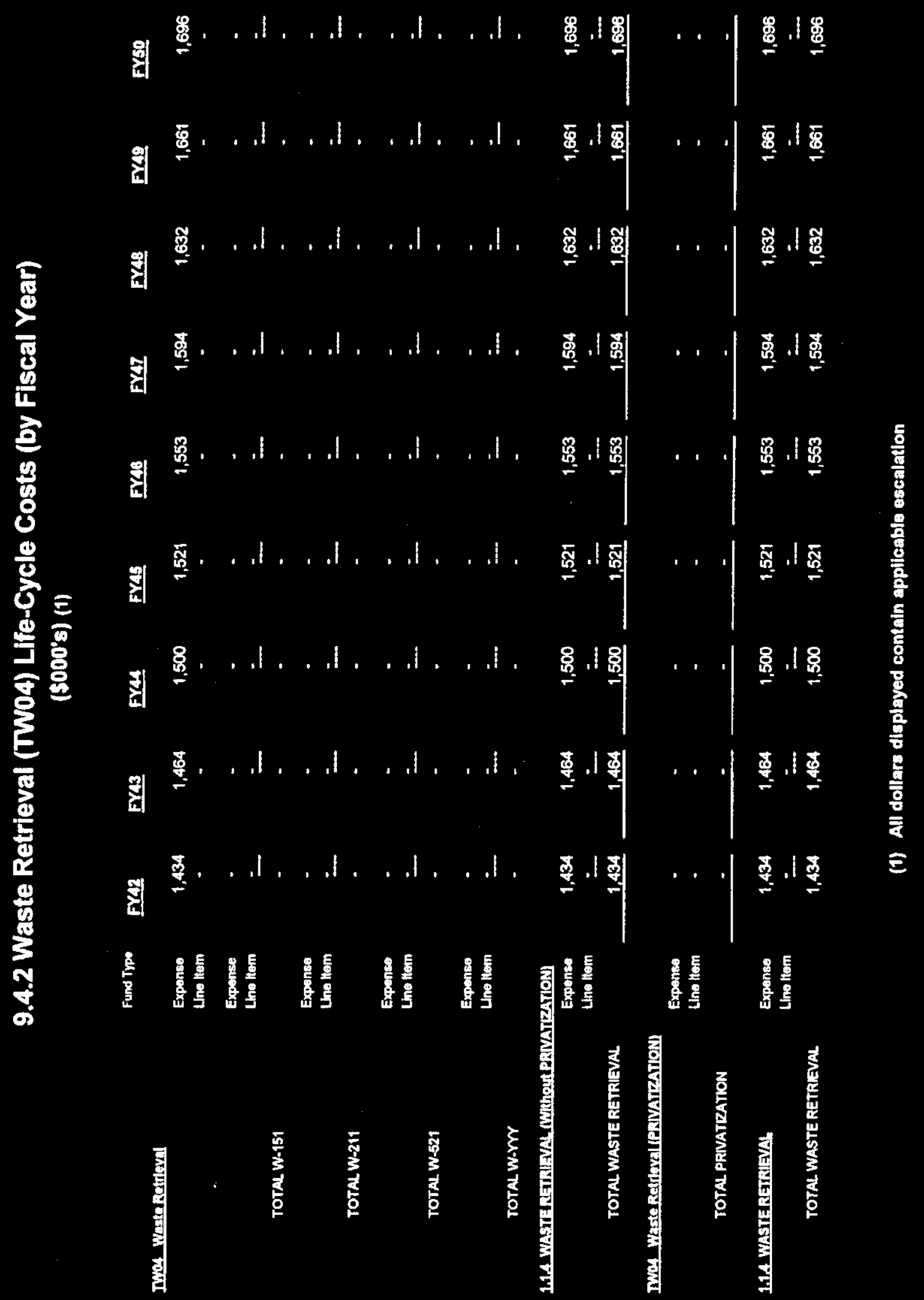




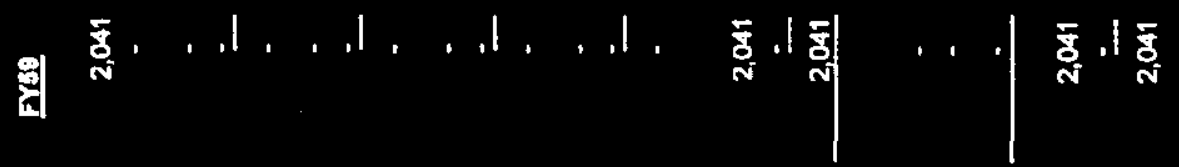

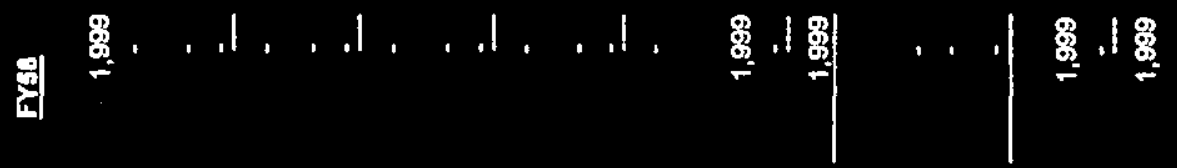

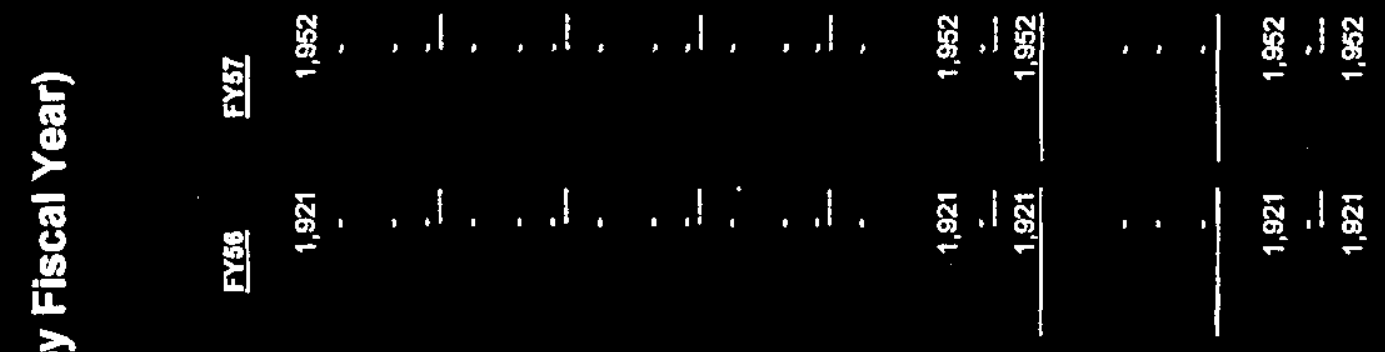

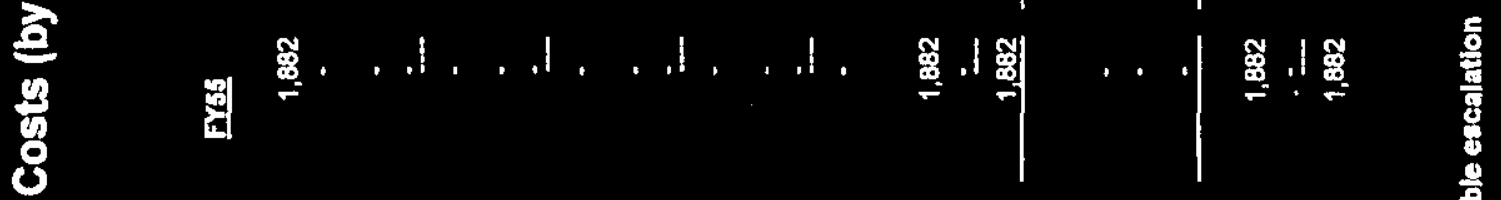

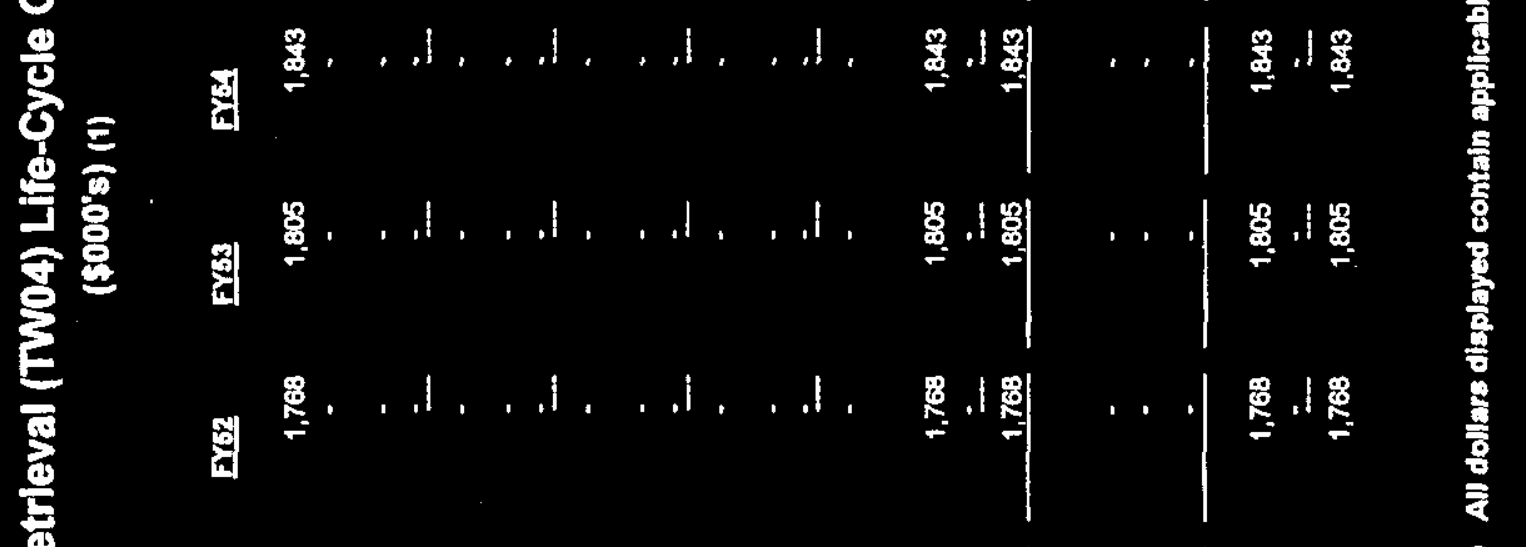

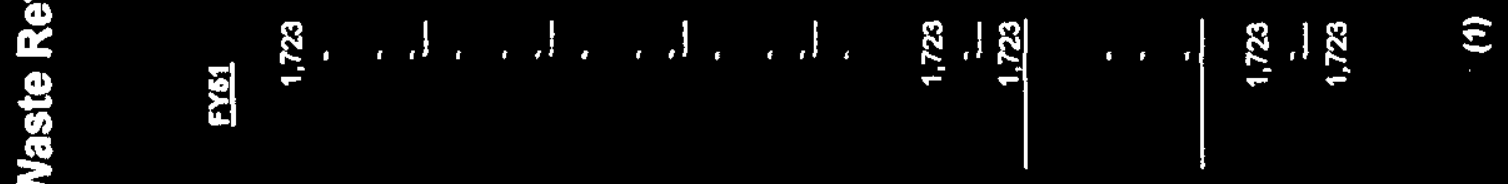

$$
\begin{aligned}
& \text { 要 } \\
& \text { 要: }
\end{aligned}
$$




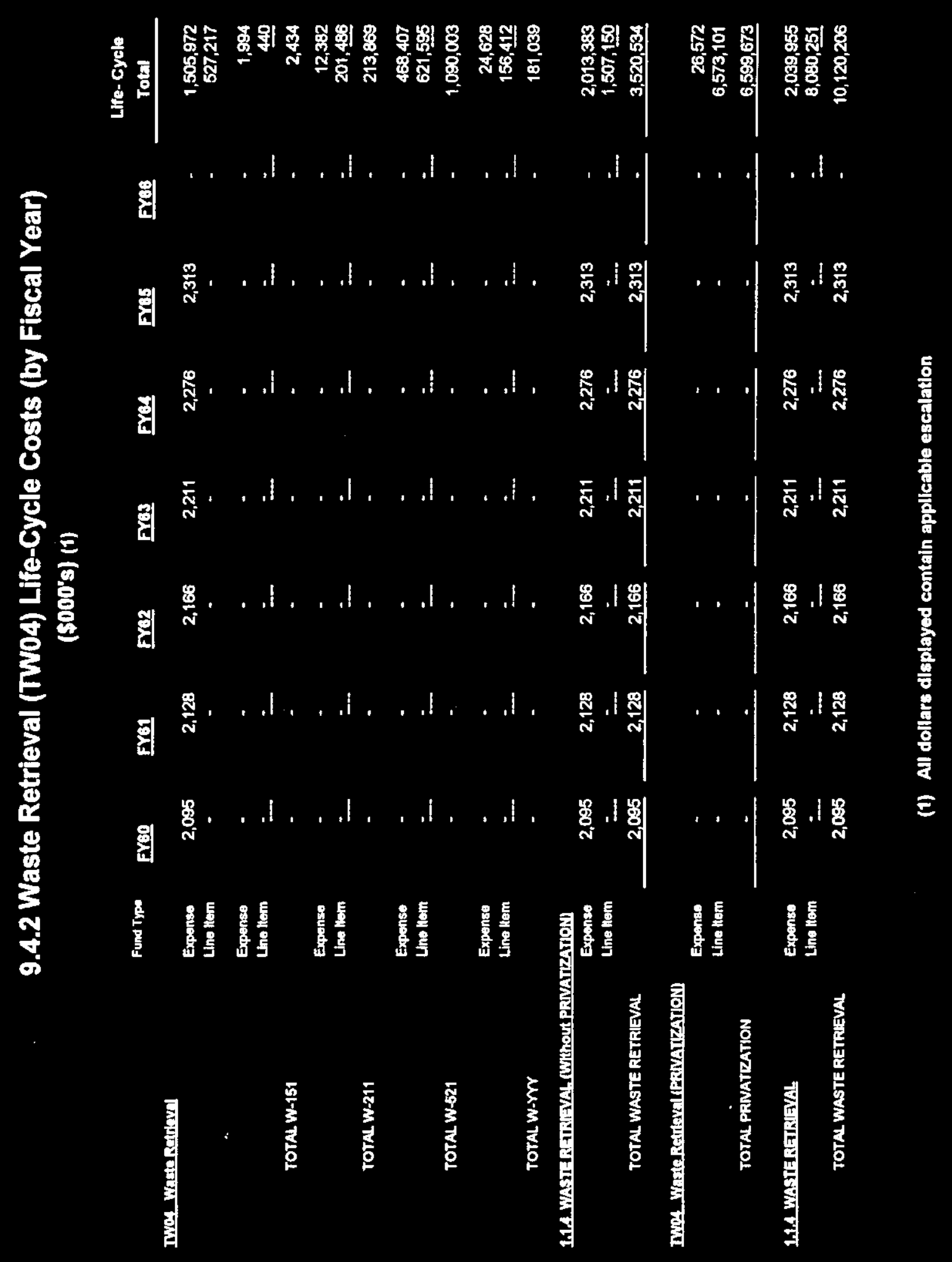




\subsubsection{Waste Retrieval (TW04) Budget Profile By Month (Execution Year) (\$000's)}

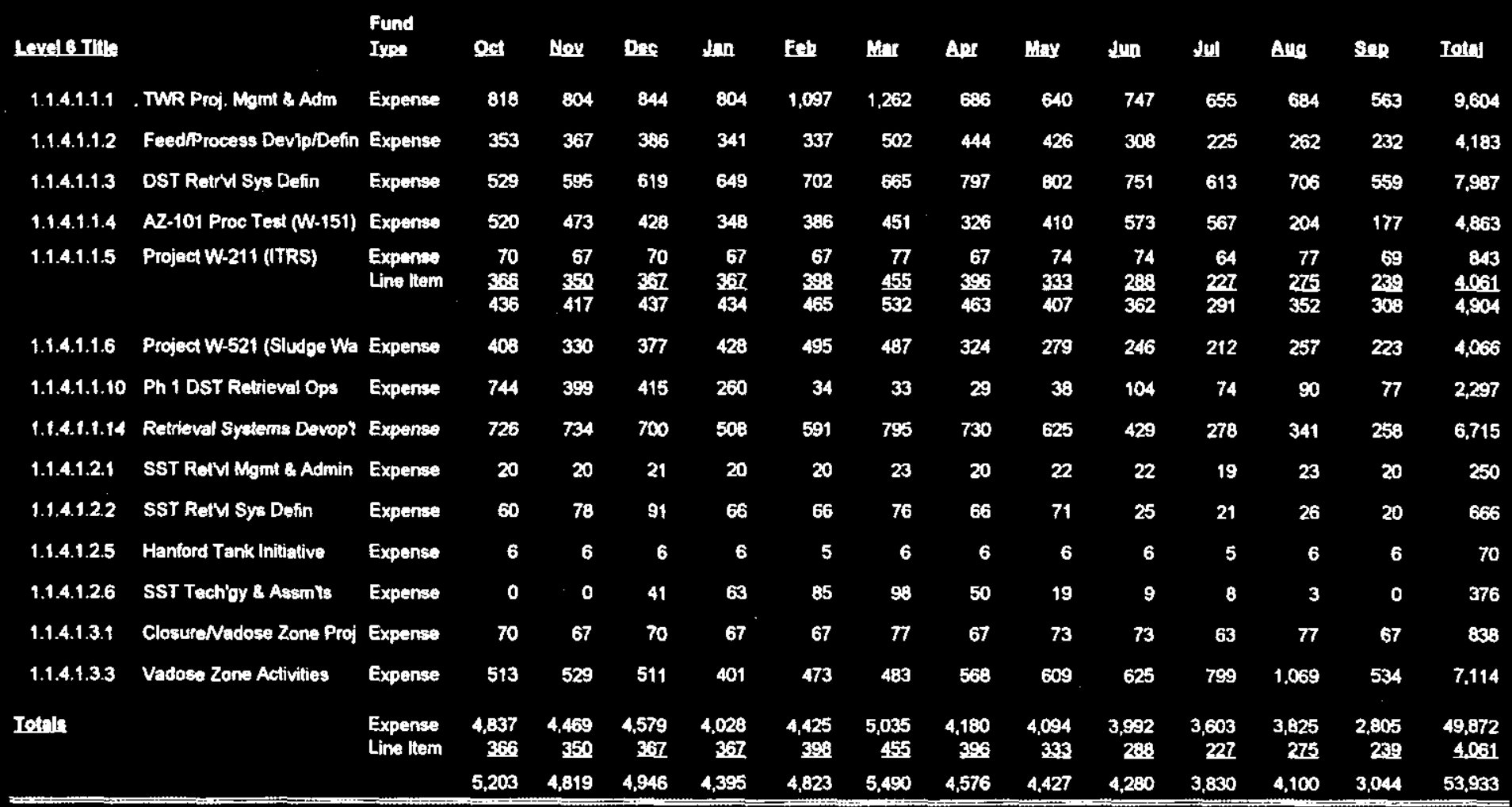

(1) Monthly Profile Based Upon P3 Calendar Month Profile, NOT Accounting Realized Hours Calendar 


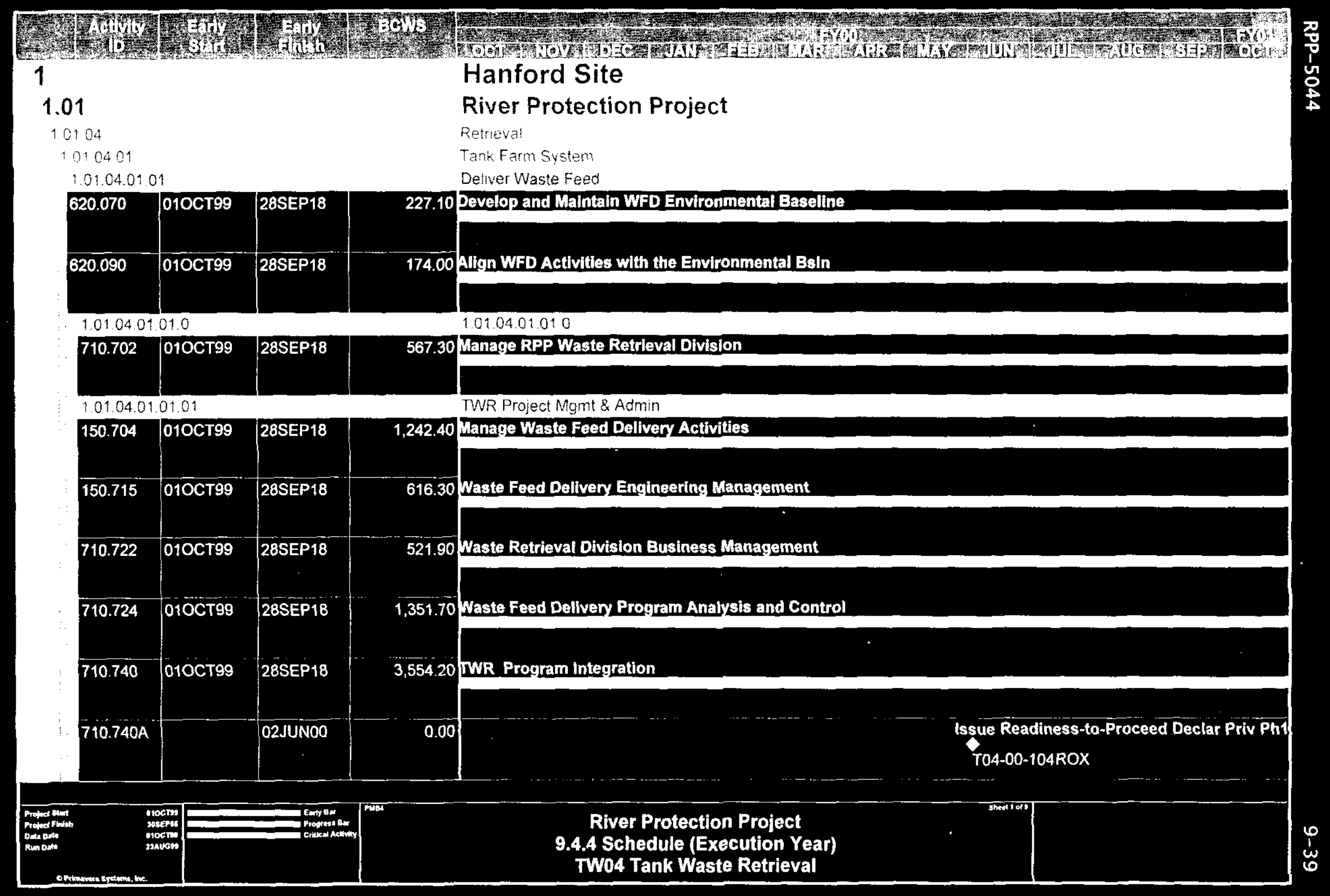




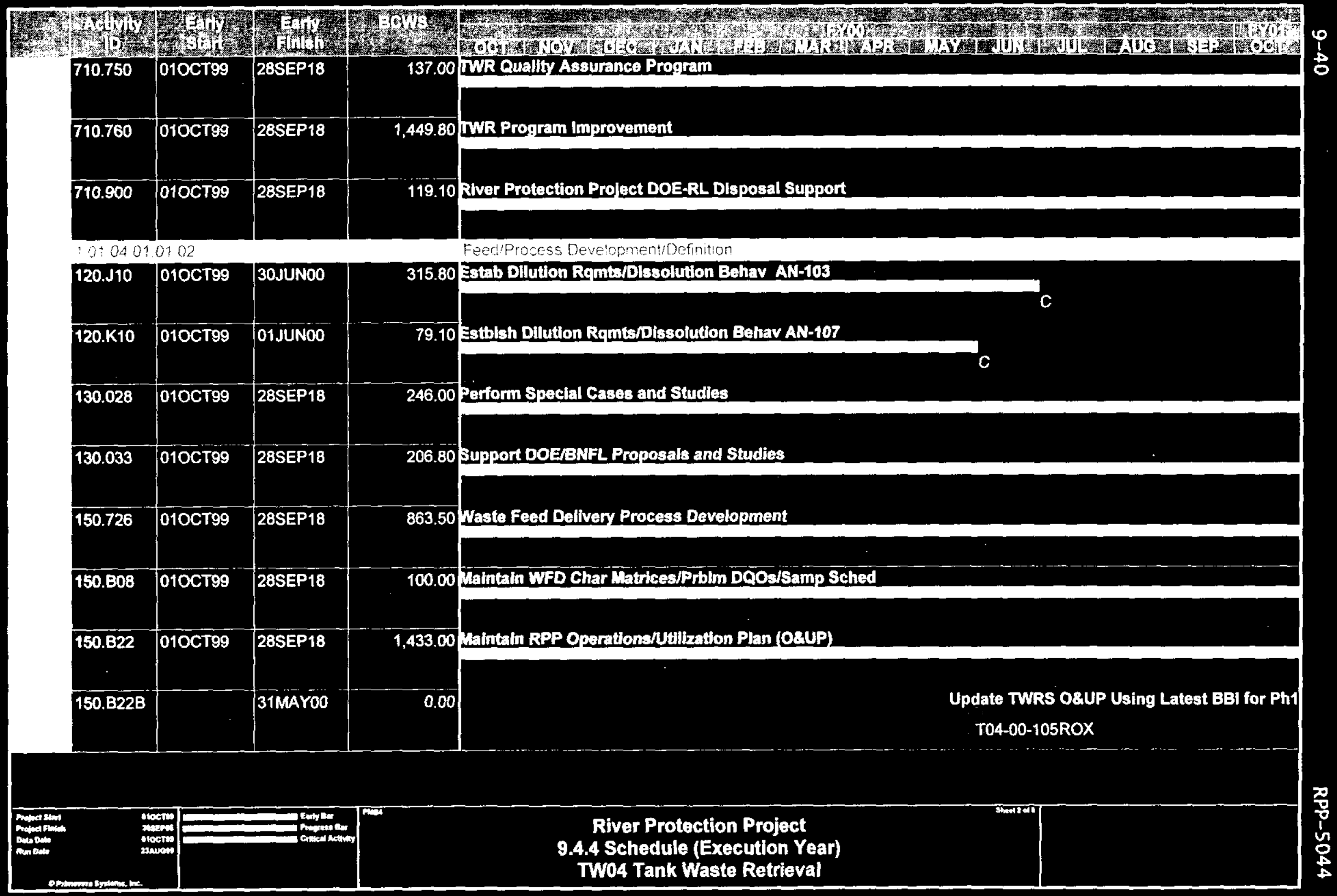




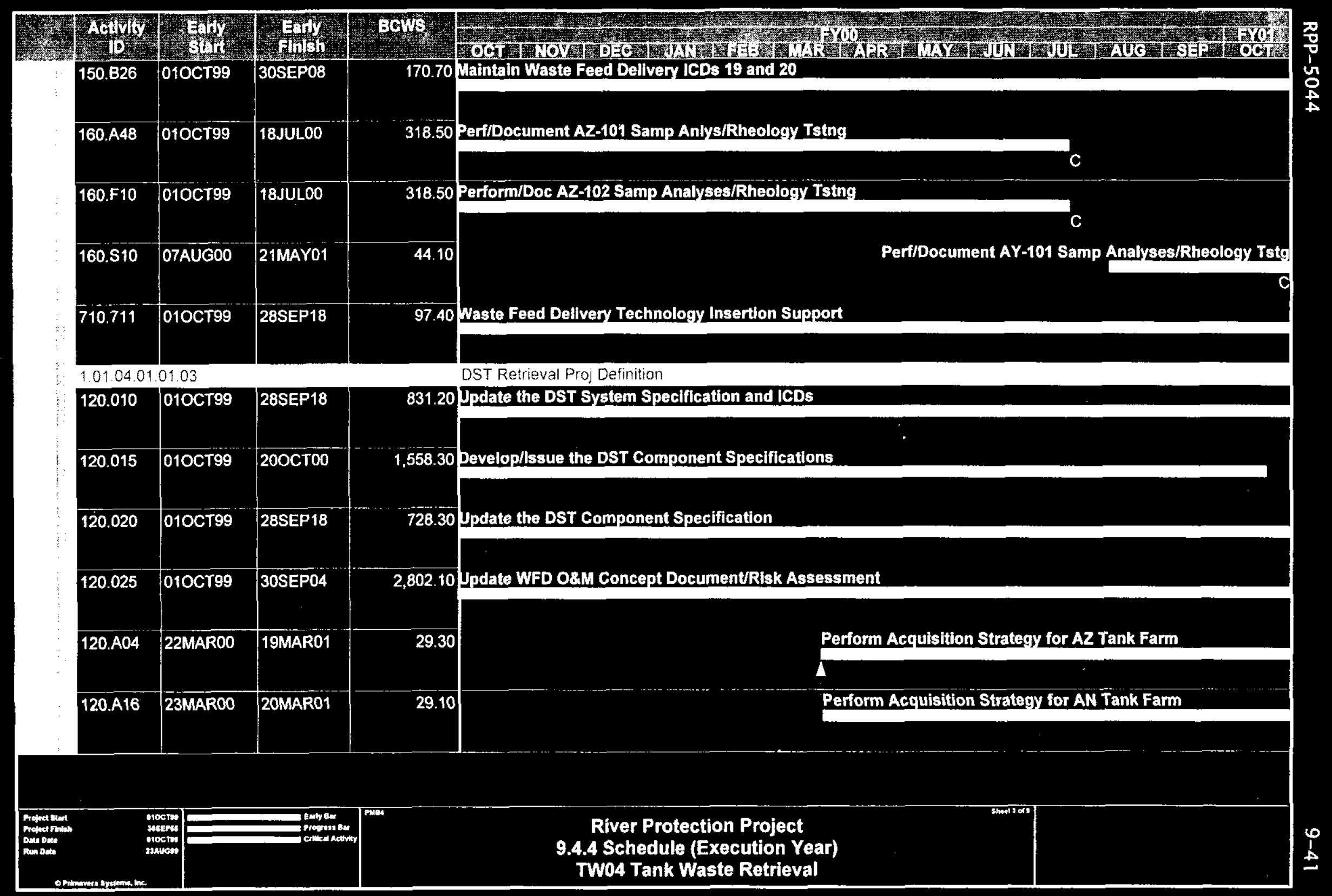




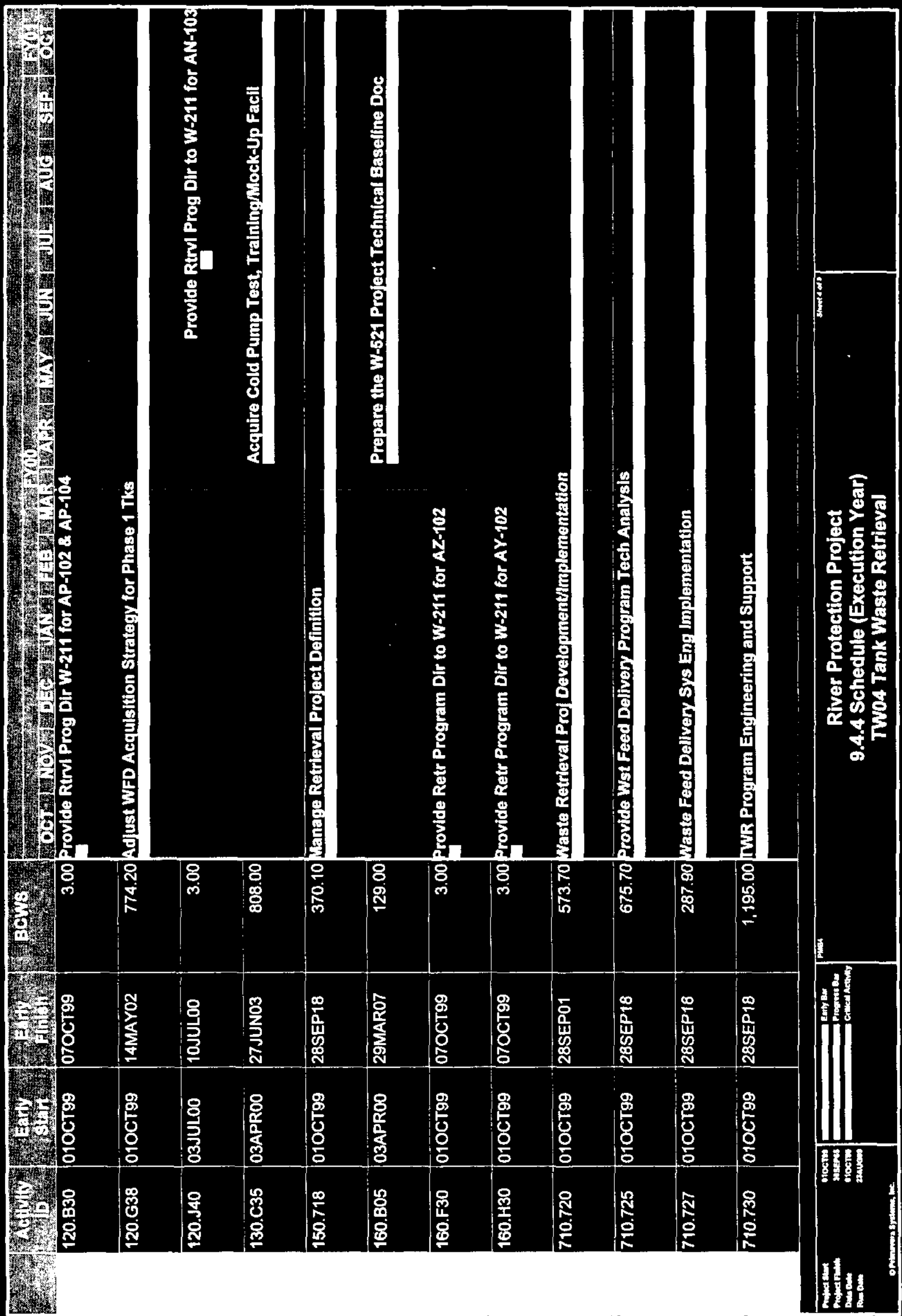




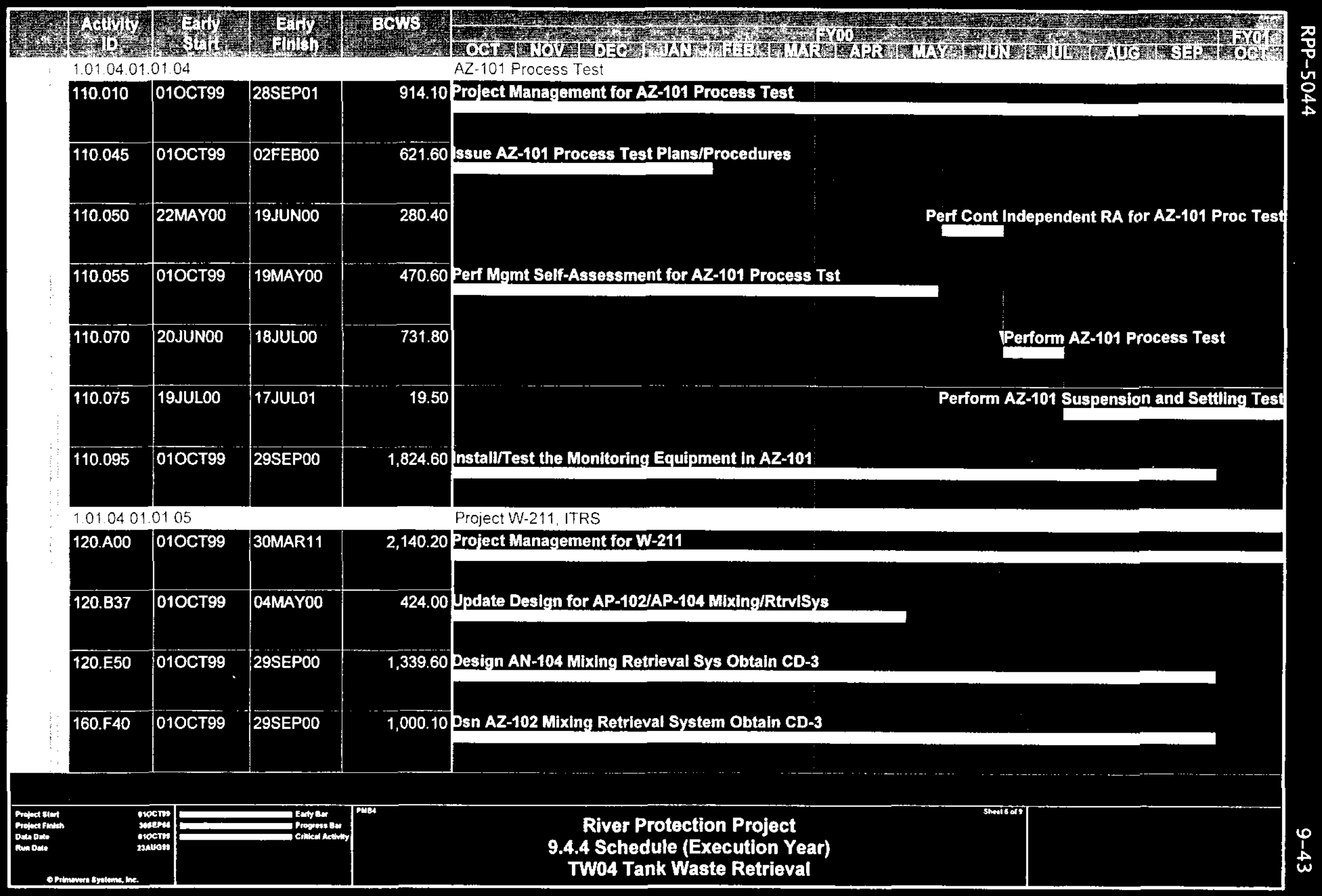




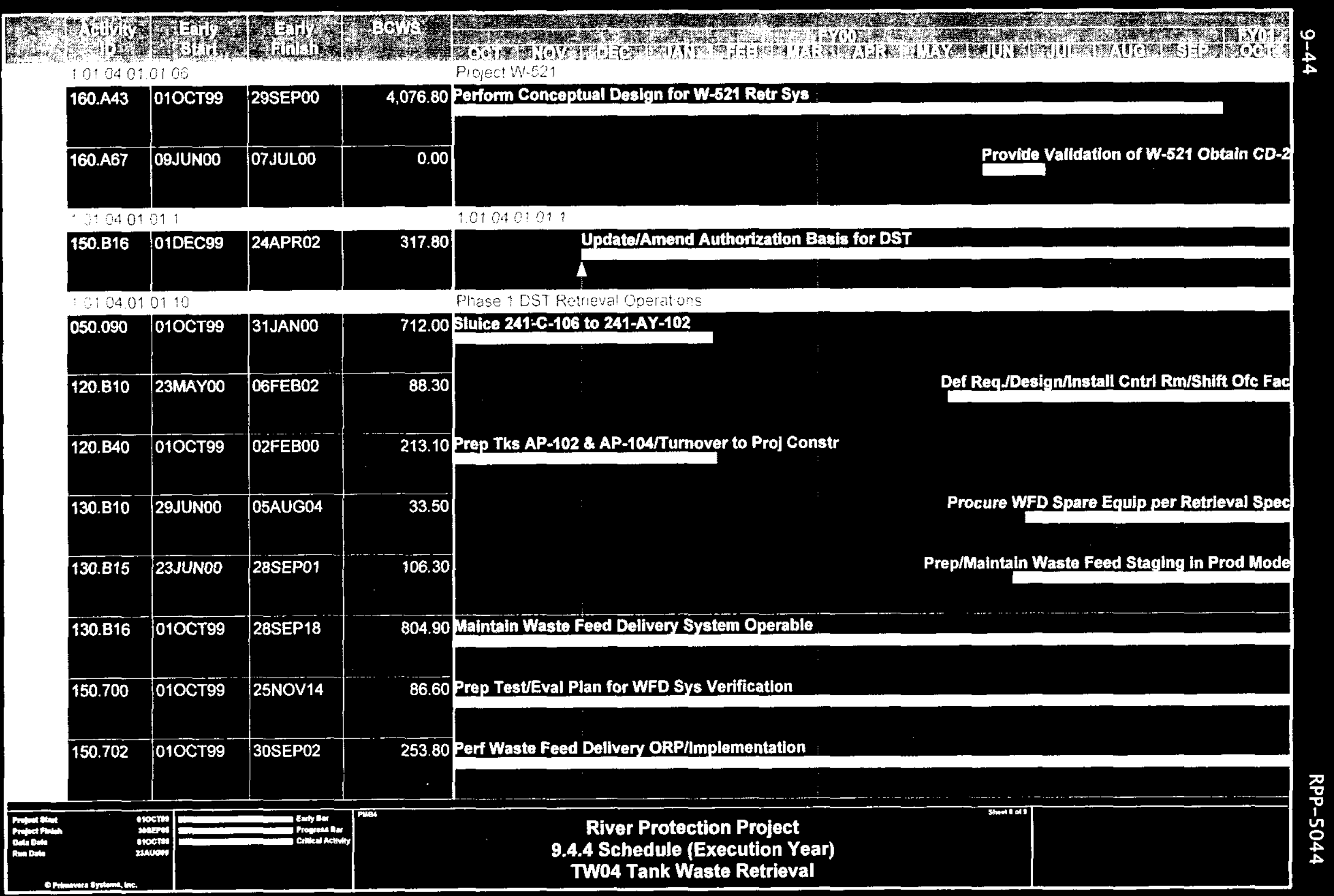




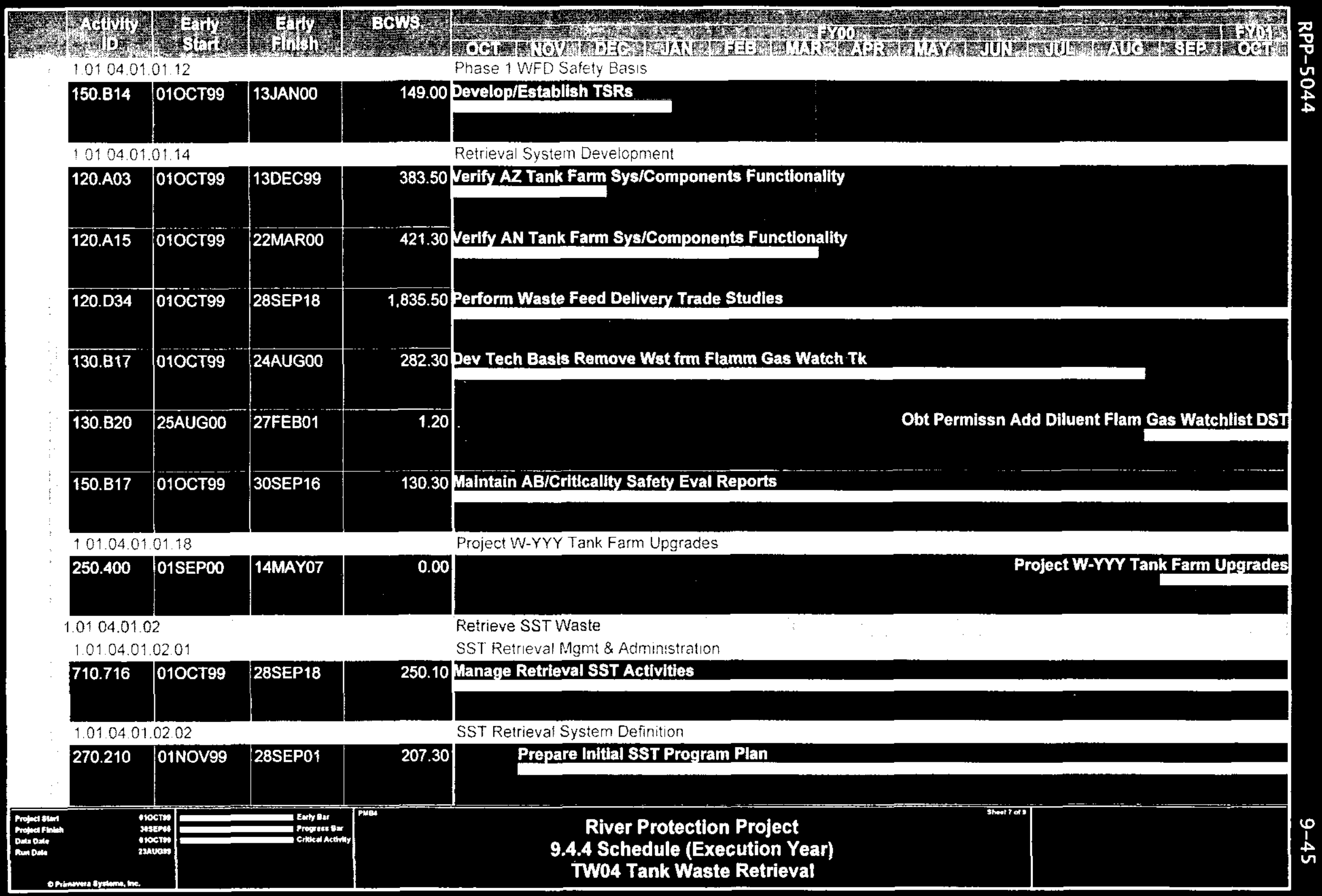




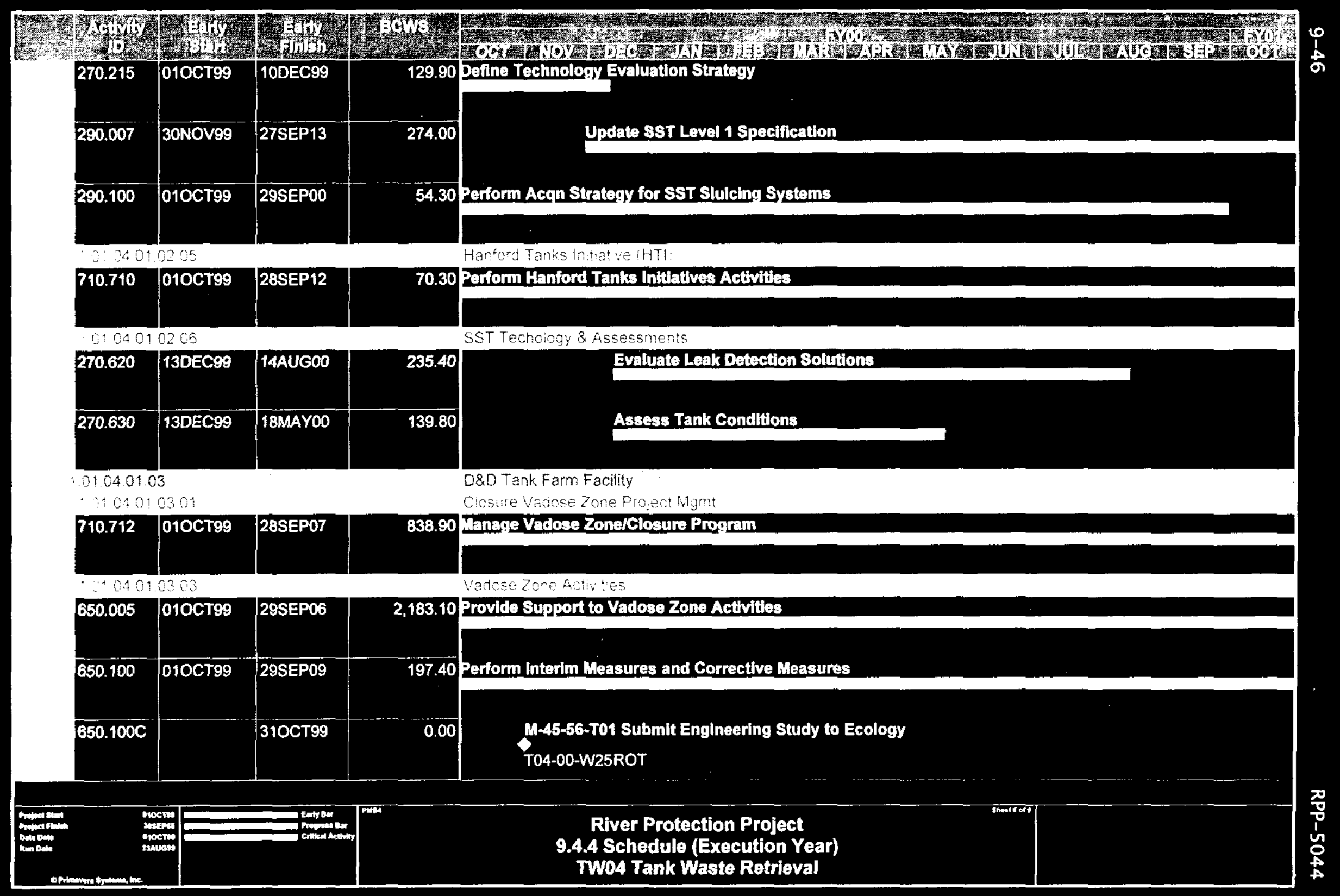




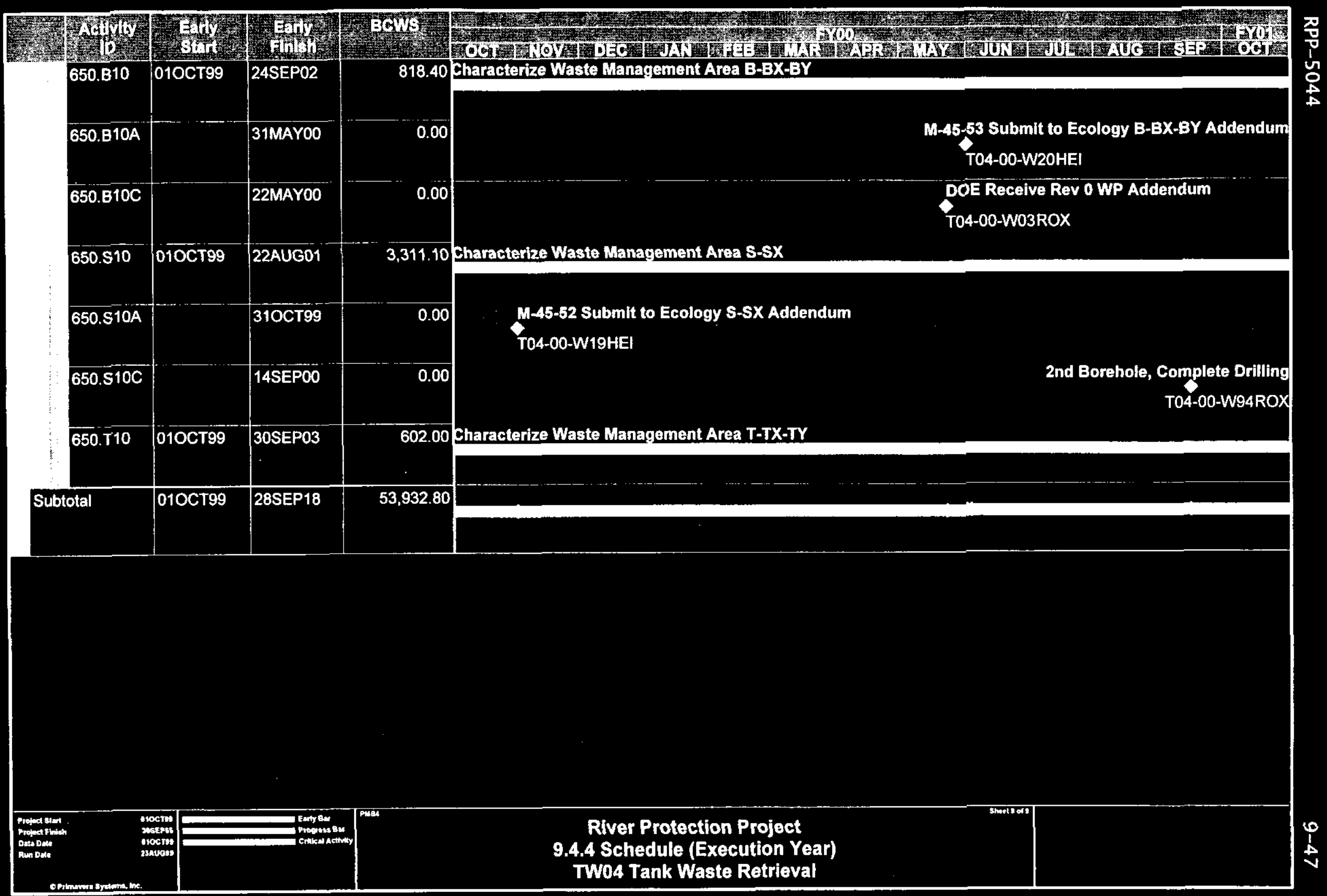


RPP-5044

9.4.5 Milestone Log (Execution Year)

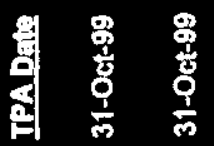

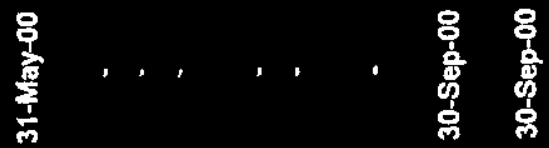

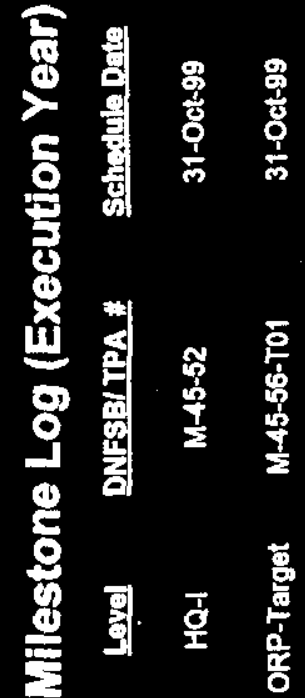

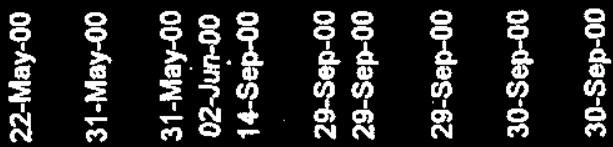

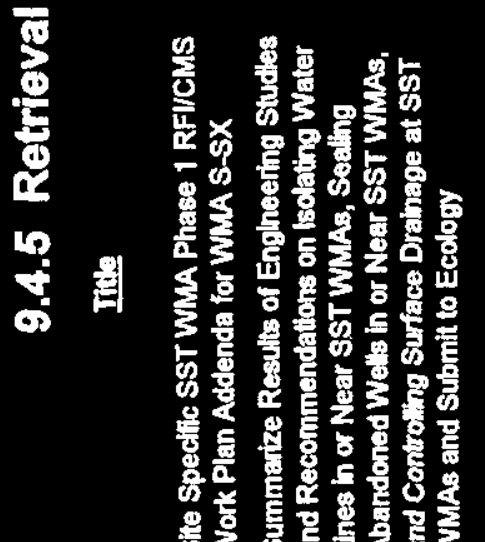

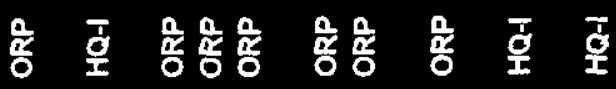

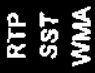

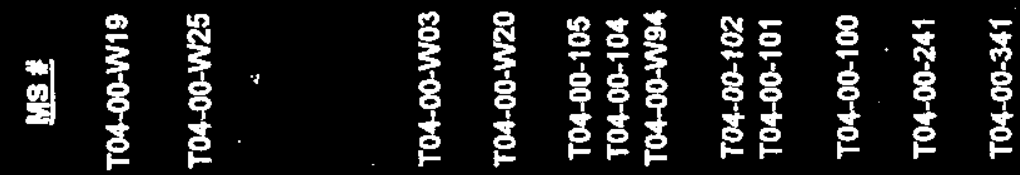

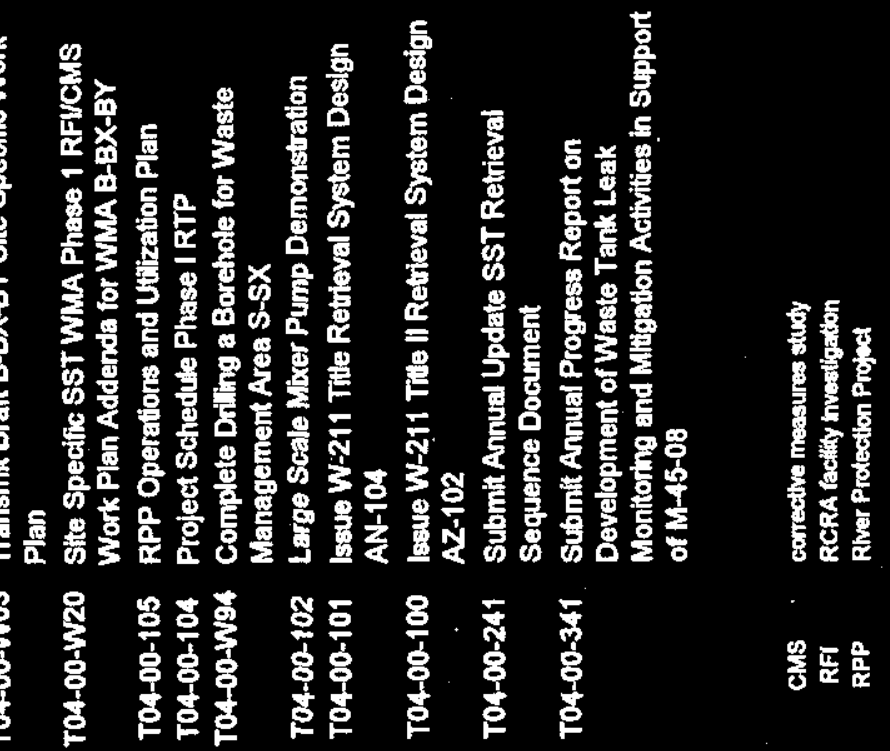




\subsection{PROCESS WASTE SUPPORT (TW05)}

\subsubsection{Mission Statement}

The mission of Process Waste Support is to assist the Office of River Protection in the management of Privatization Phase 1 and Privatization Phase 2. This includes integrating privatized and non-privatized activities; assisting in the execution of the privatization contracts; managing interfaces with the PHMC and private contractors; assisting in managing the interfaces with stakeholders and regulators, and assisting in the management of the key risks and key decisions associated with tank waste disposal. 
RPP-5044

9-50

9.5.2 Life Cycle Costs by Fiscal Year

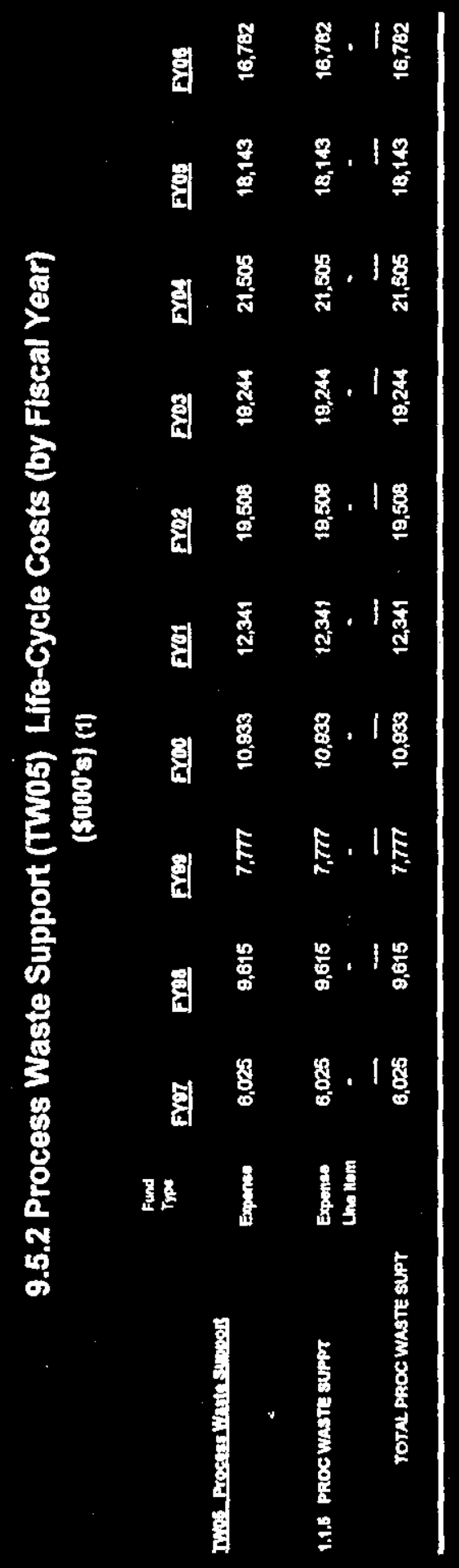




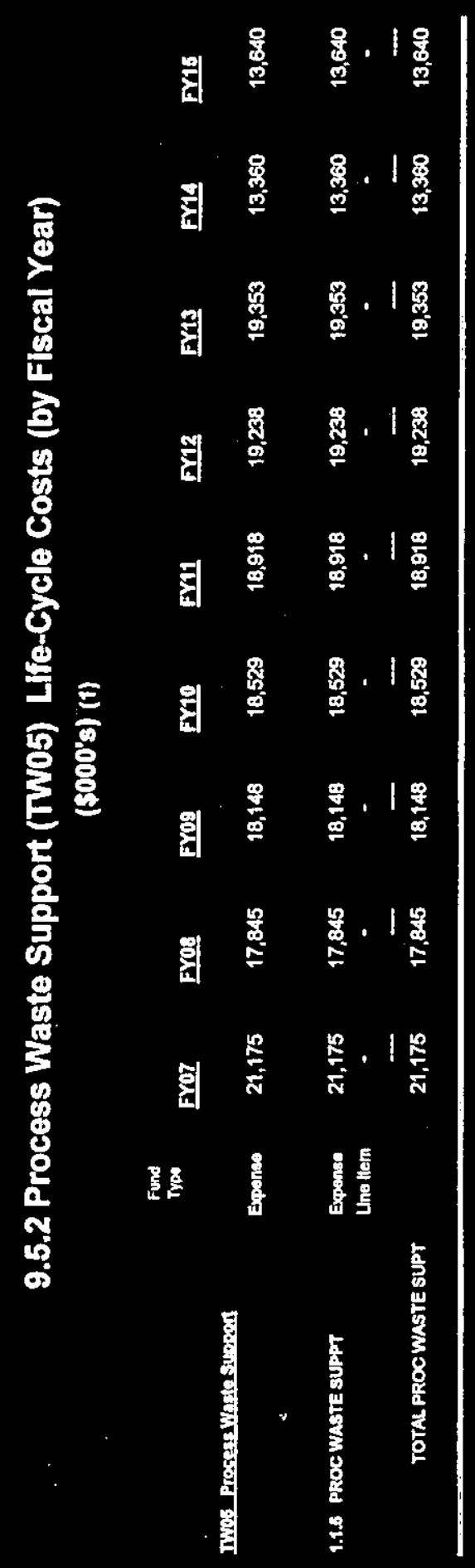




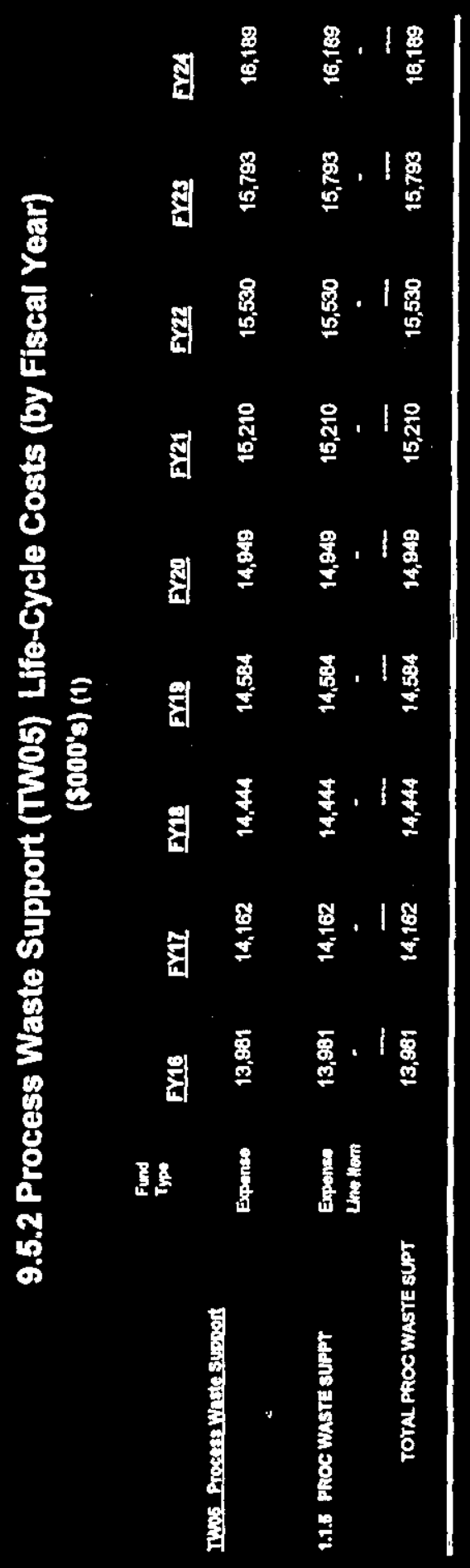




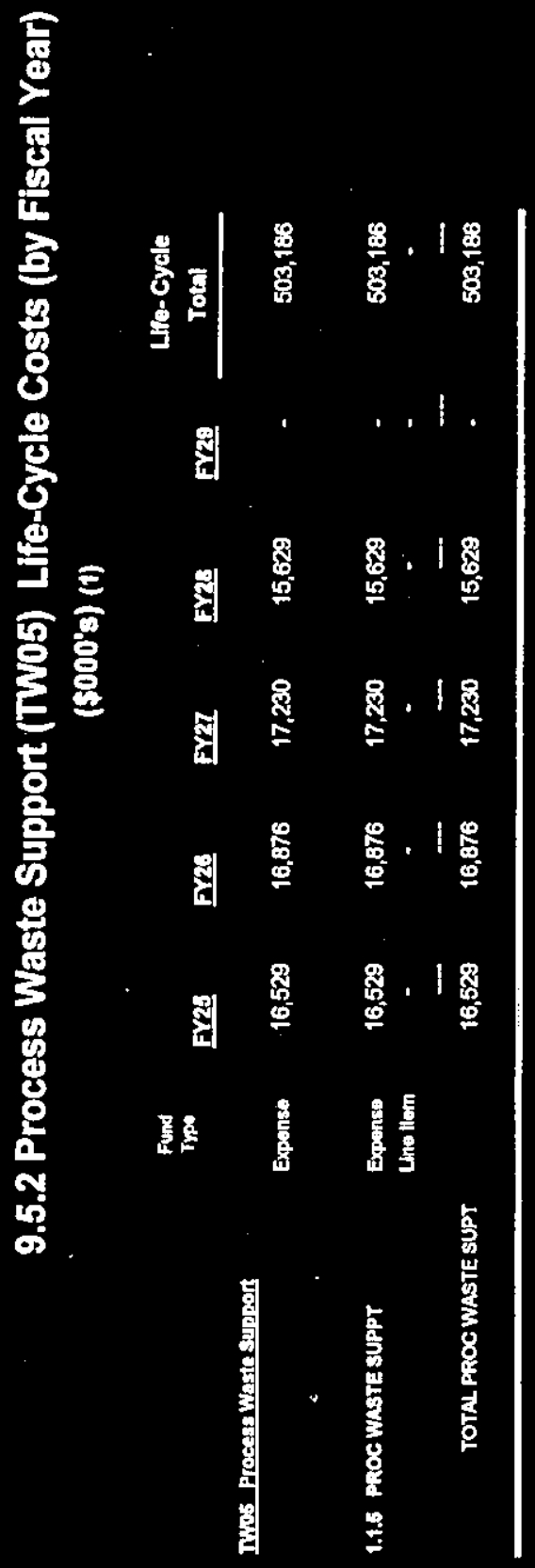


RPP-5044

9-54

9.5.3 Budget Profile by Month (Execution Year)

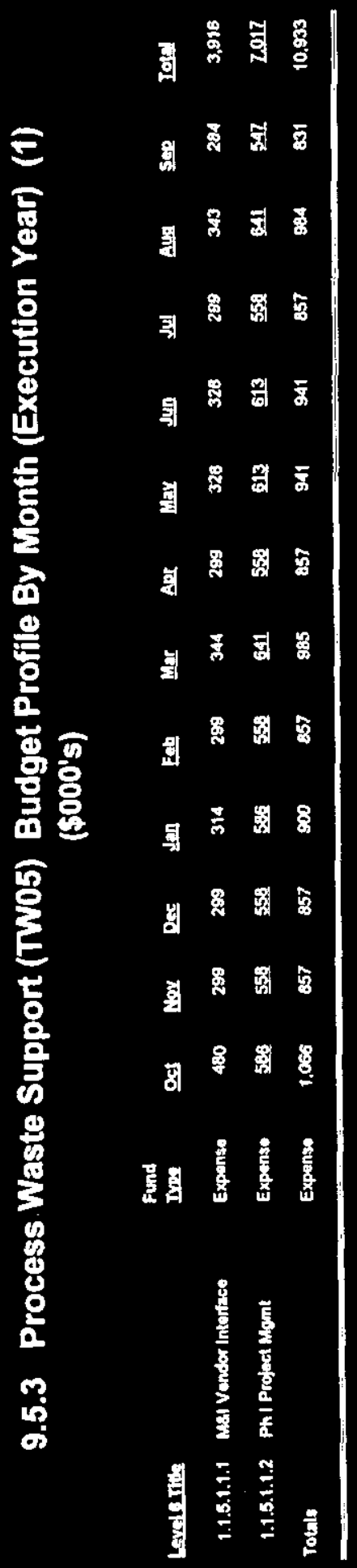




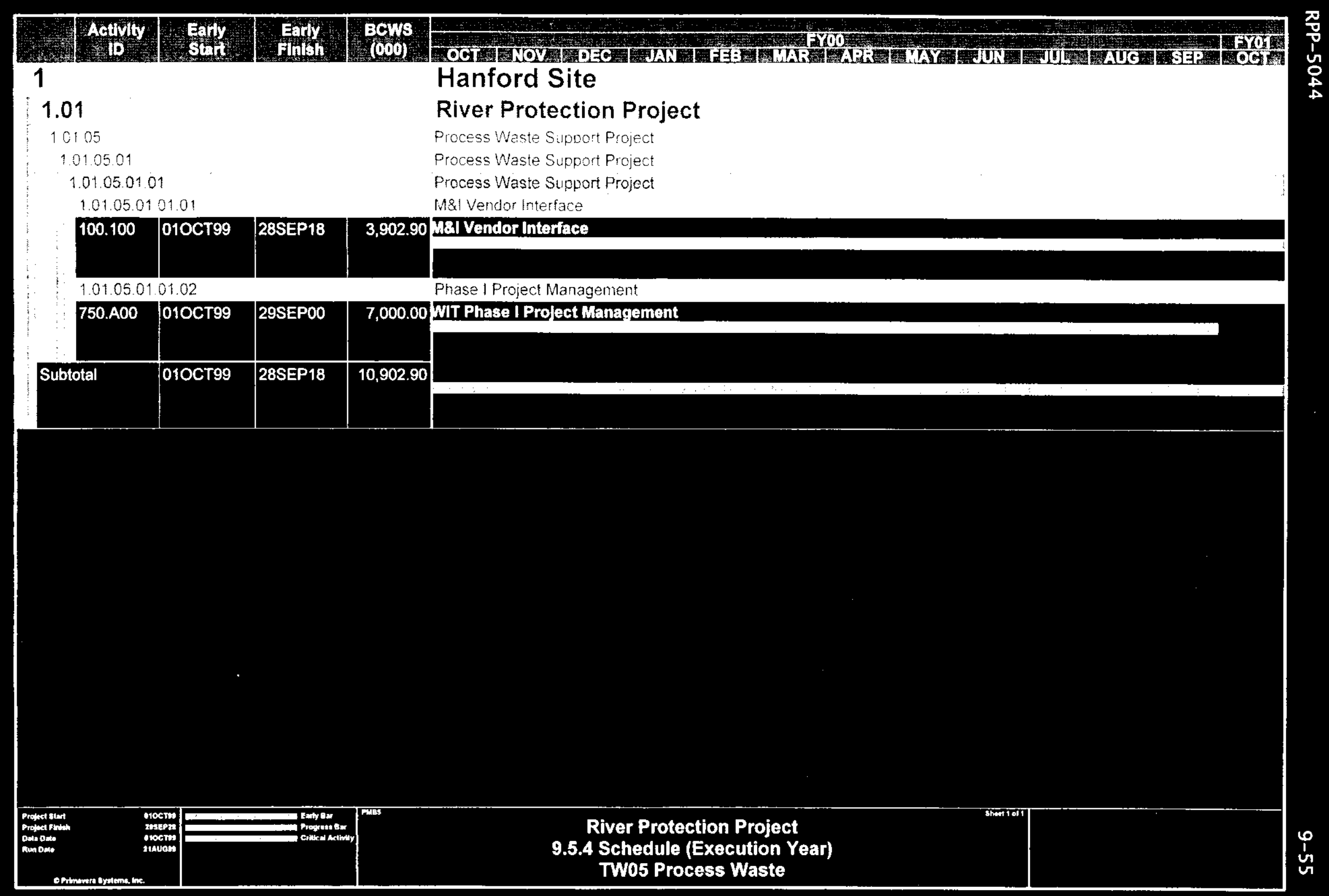


RPP-5044

9-56

9.5.5 Milestone Log (Execution Year)

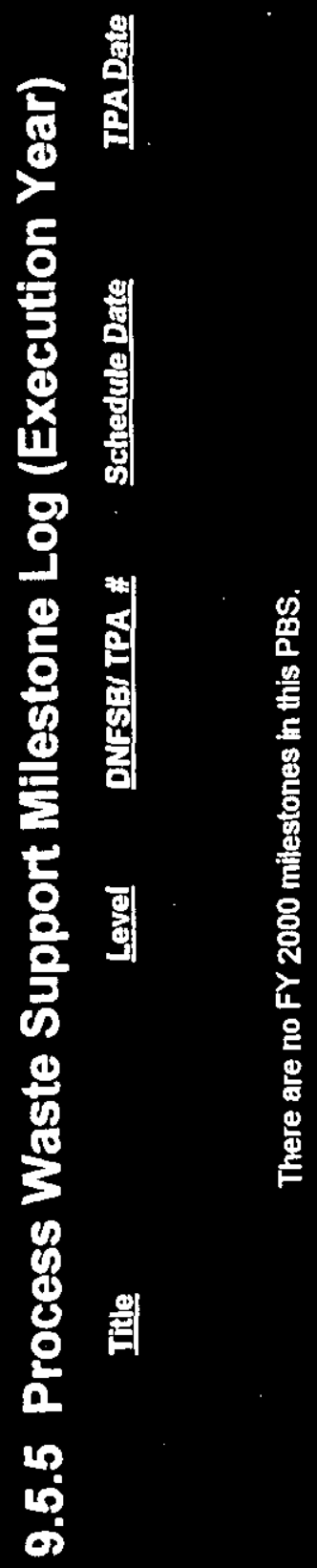

열 


\subsection{PRIVATIZATION PHASE 1 (TW06)}

\subsubsection{Mission Statement}

Phase 1 objectives are to demonstrate the technical and business viability of using privatized facilities to treat Hanford Site tank waste; define and maintain required levels of radiological, nuclear, process, and occupational safety; maintain environmental protection and compliance; and substantially reduce life-cycle costs and time required to treat Hanford Site tank waste. This project demonstrates progress in limiting potential contamination of the Columbia River by removing high-level waste from underground storage tanks, which can leak into the groundwater. 
RPP-5044

9-58

9.6.2 Life-Cycle Costs by Fiscal Year

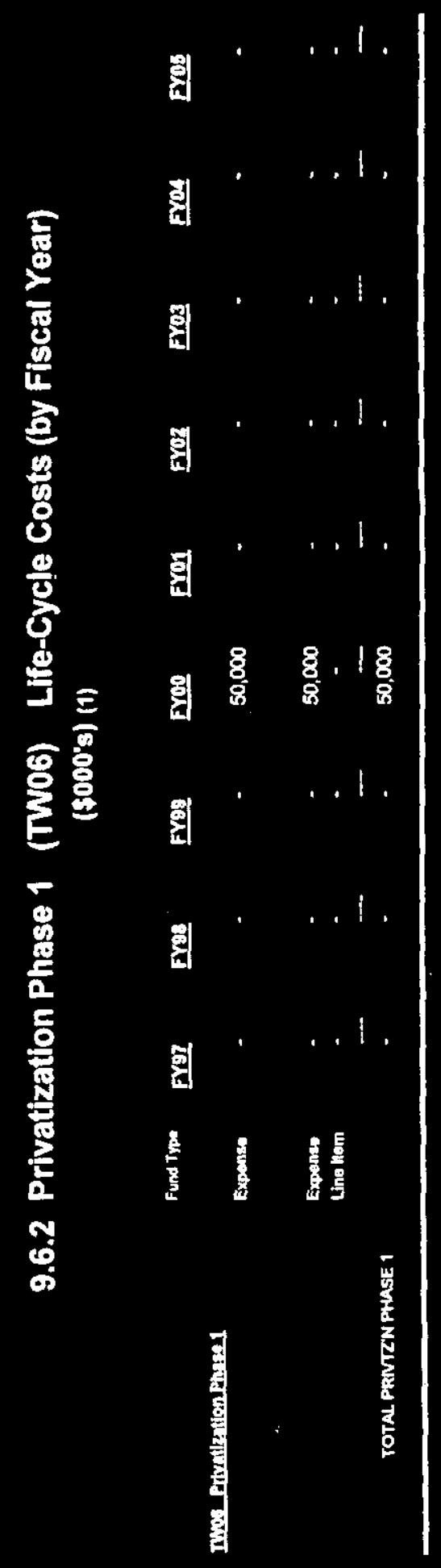




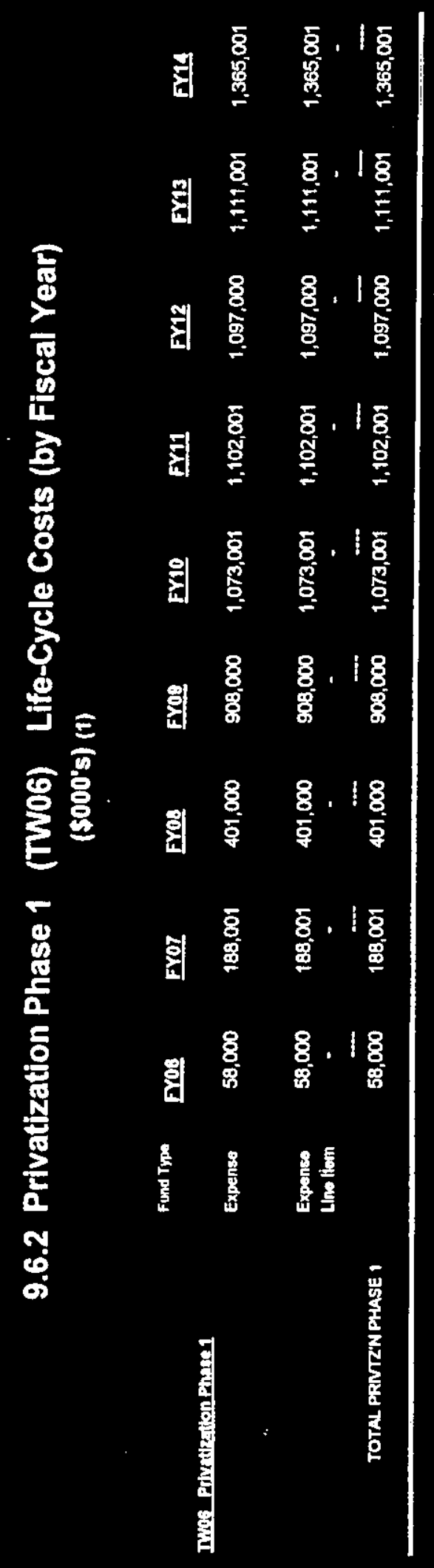


RPP-5044

9-60

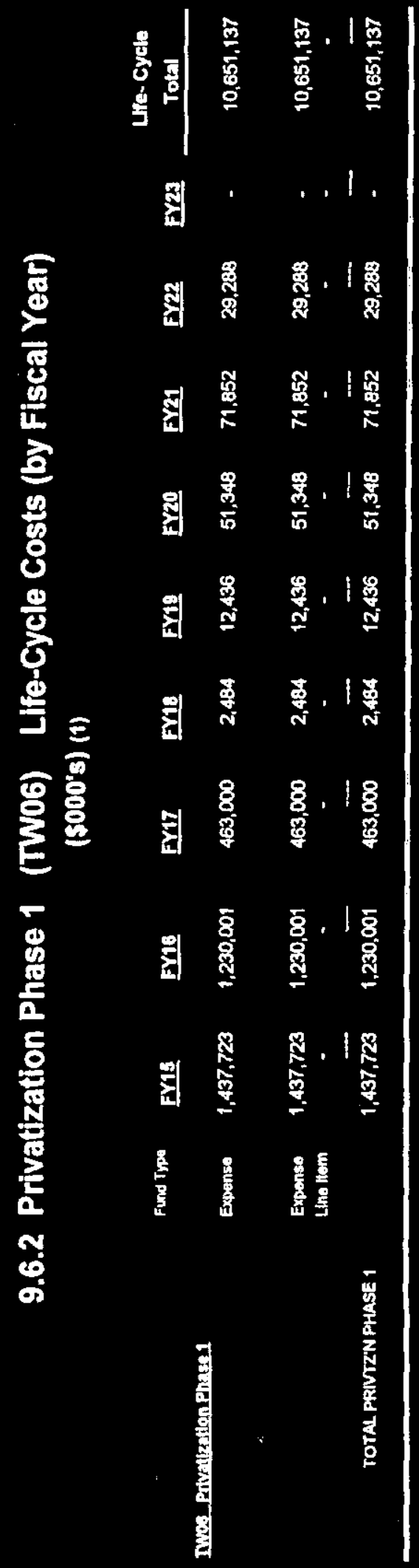

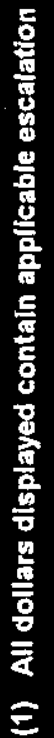




\subsubsection{Budget Profile by Month (Execution Year)}

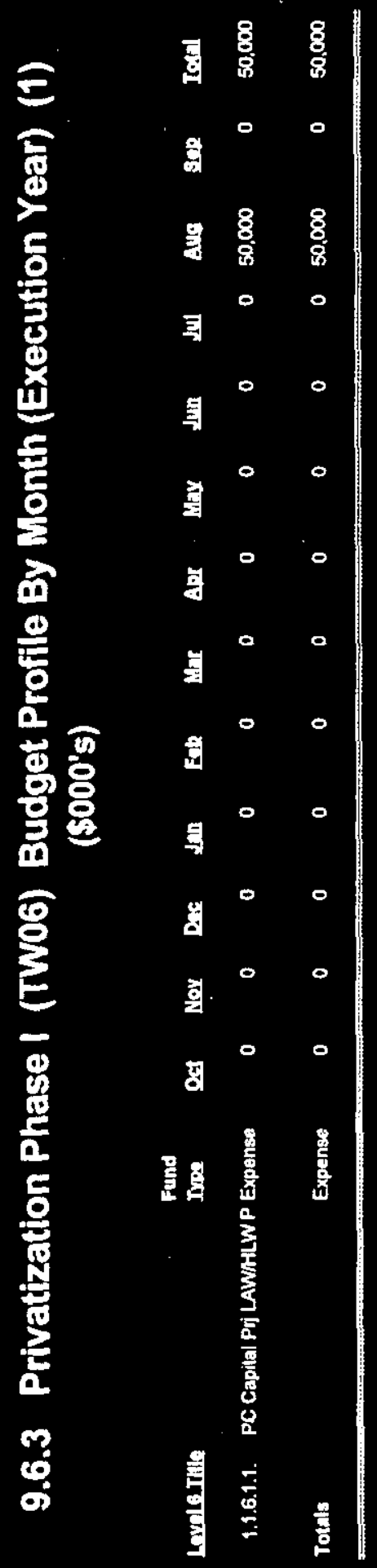




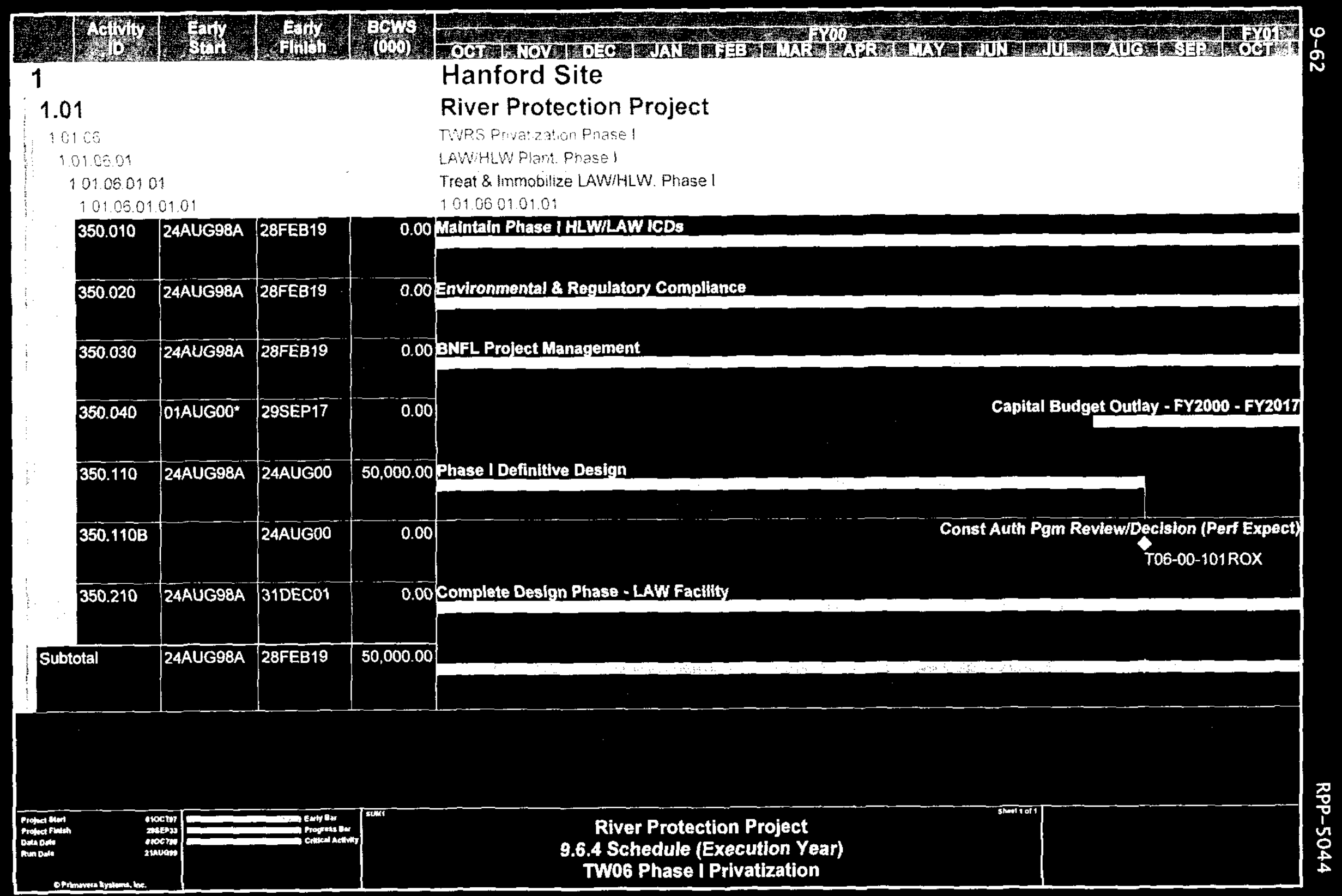




\subsubsection{Milestone Log (Execution Year)}

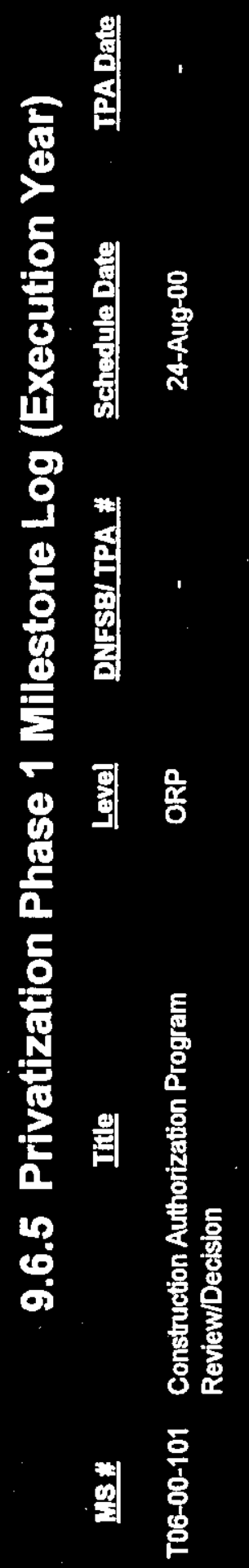


RPP-5044

9-64

This page intentionally left blank. 


\subsection{PRIVATIZATION PHASE 2 (TW07)}

\subsubsection{Mission Statement}

Phase 2 will be the full-scale production phase, in which the facilities will be configured so all the waste can be processed. The objectives of Phase 2 are to implement the lessons from Phase 1; to process all tank waste and the cesium and strontium capsules into forms suitable for final disposal; achieve competition and cost savings; and meet the Tri-Party Agreement milestones. 
RPP-5044

9-66

\subsubsection{Life-Cycle Costs by Fiscal Year}

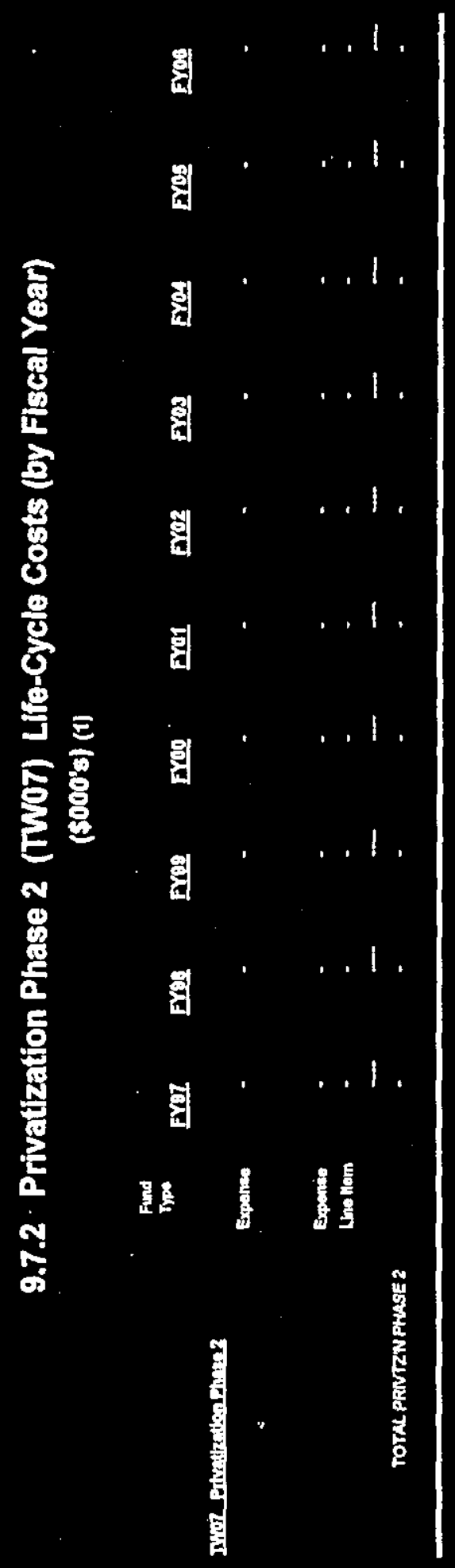




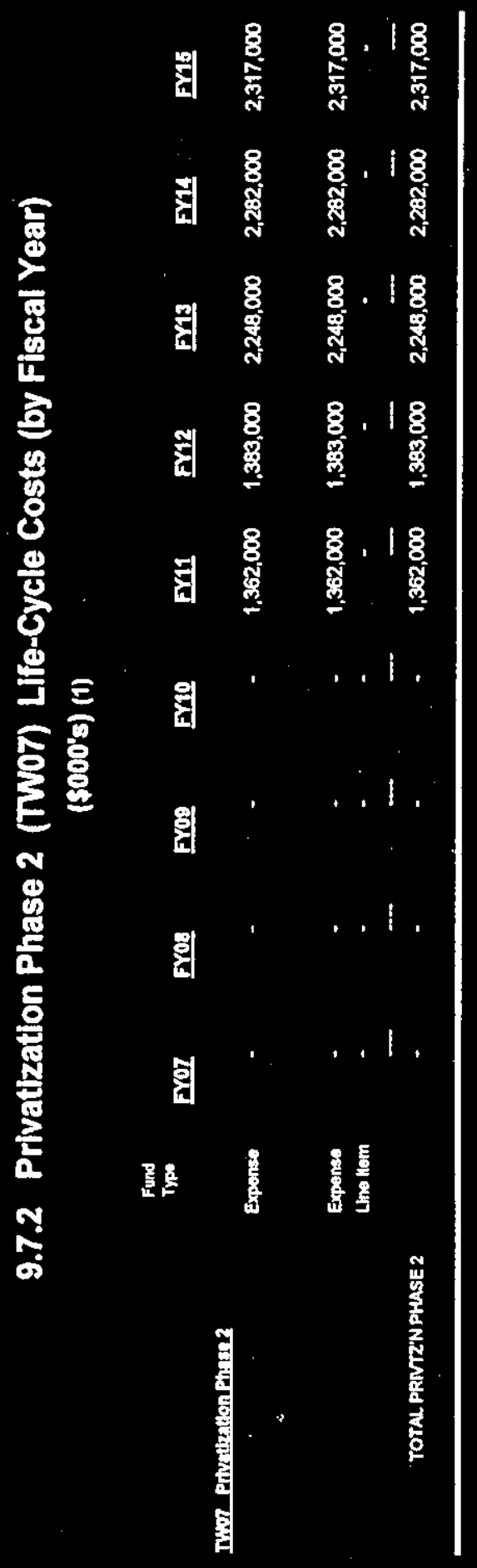


RPP-5044

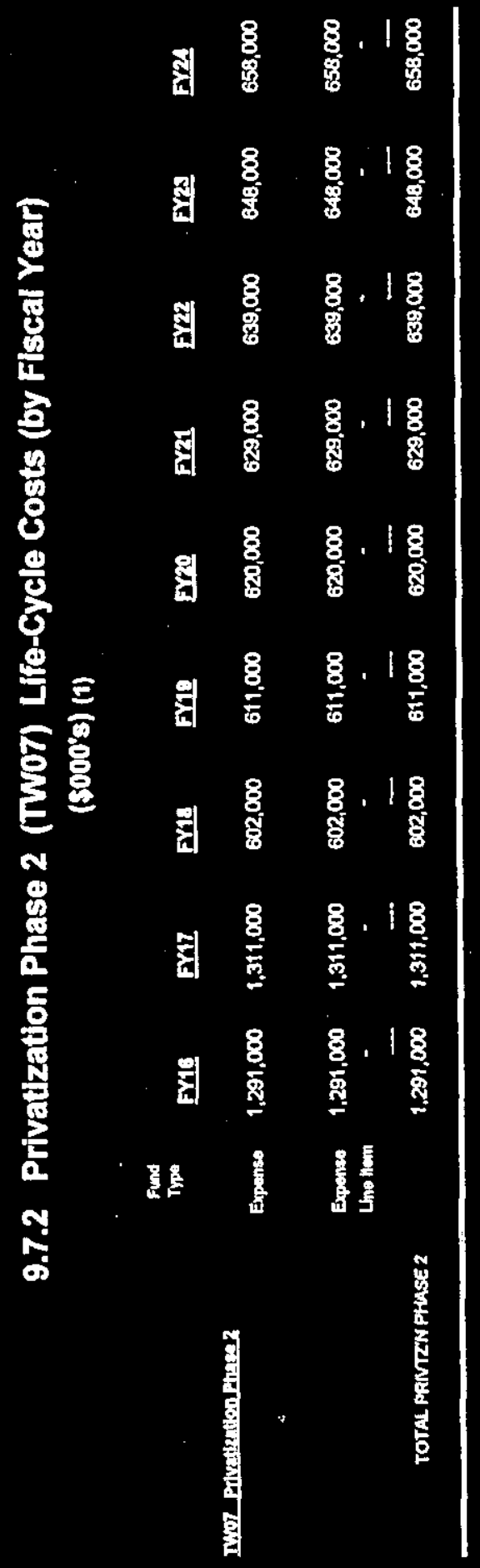




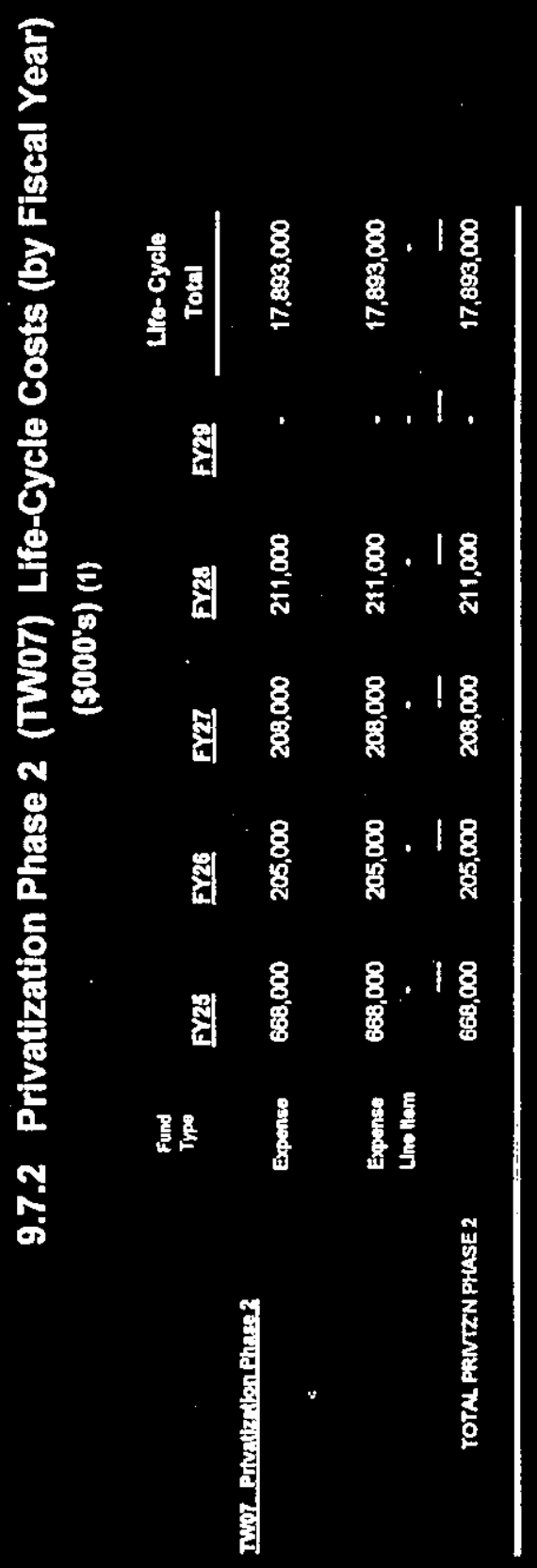


RPP-5044

9-70

9.7.3 Budget Profile by Month (Execution Year)

There are no FY 2000 activities.

\subsubsection{Schedule (Execution Year)}

There are no FY 2000 activities.

\subsubsection{Milestone Log (Execution Year)}

There are no FY 2000 activities. 


\subsection{PRIVATIZATION INFRASTRUCTURE (TW08)}

\subsubsection{Mission Statement}

Part of the RPP mission is to separate the Hanford Site's tank waste into low-activity waste (LAW) and high-level waste (HLW) fractions and to immobilize and dispose of them in an environmentally sound, safe, and cost-effective manner. This will be done using a two-phased strategy involving private contractors. Phase 1 will encompass treating, immobilizing, and storing or disposing of approximately 10 percent (by volume) of the tank waste. Phase 2 will encompass pretreating, immobilizing, and disposing of the remaining 90 percent using full-scale production facilities.

The contract that DOE and the Privatization Contractor signed in August 1998 establishes the general scope and timing requirements for the Privatization Infrastructure Program. These requirements are defined in more detail in the TWRS Privatization Project Interface Control Document (BNFL 1998), and will be modified based on DOE's decision on whether to proceed with privatization. This decision will be made in August 2000. 


\subsubsection{Life-Cycle Costs by Fiscal Year}

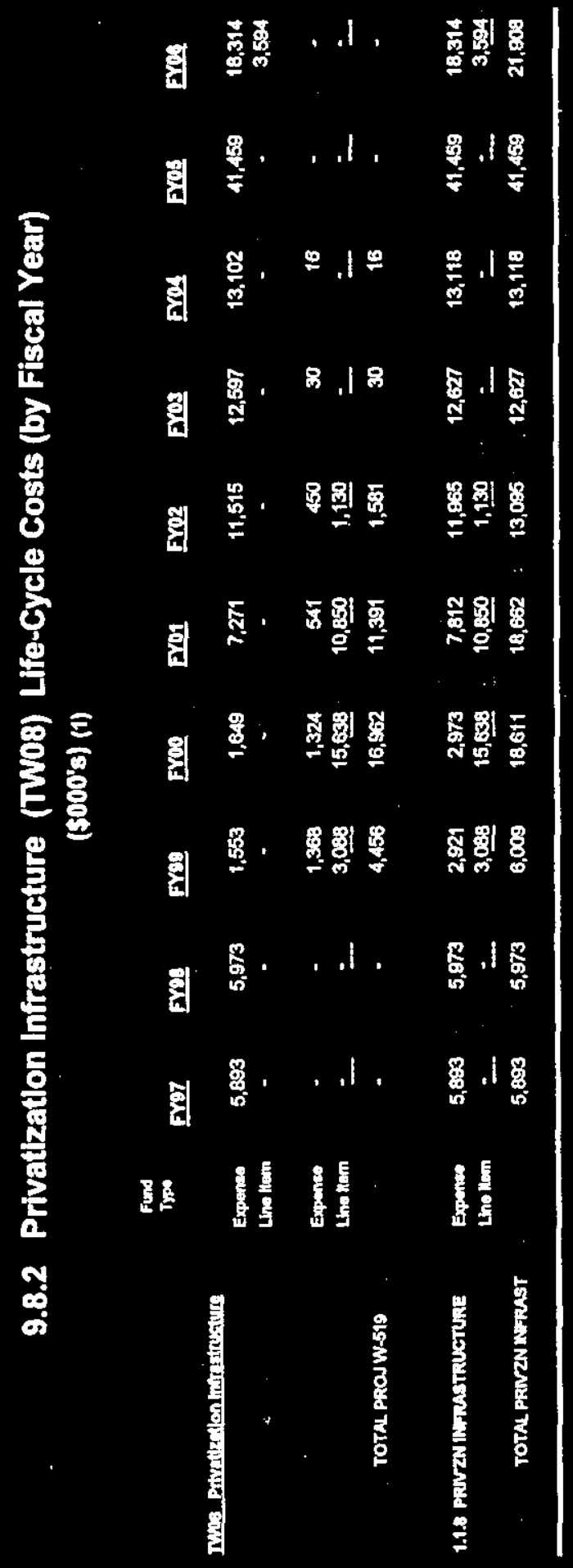




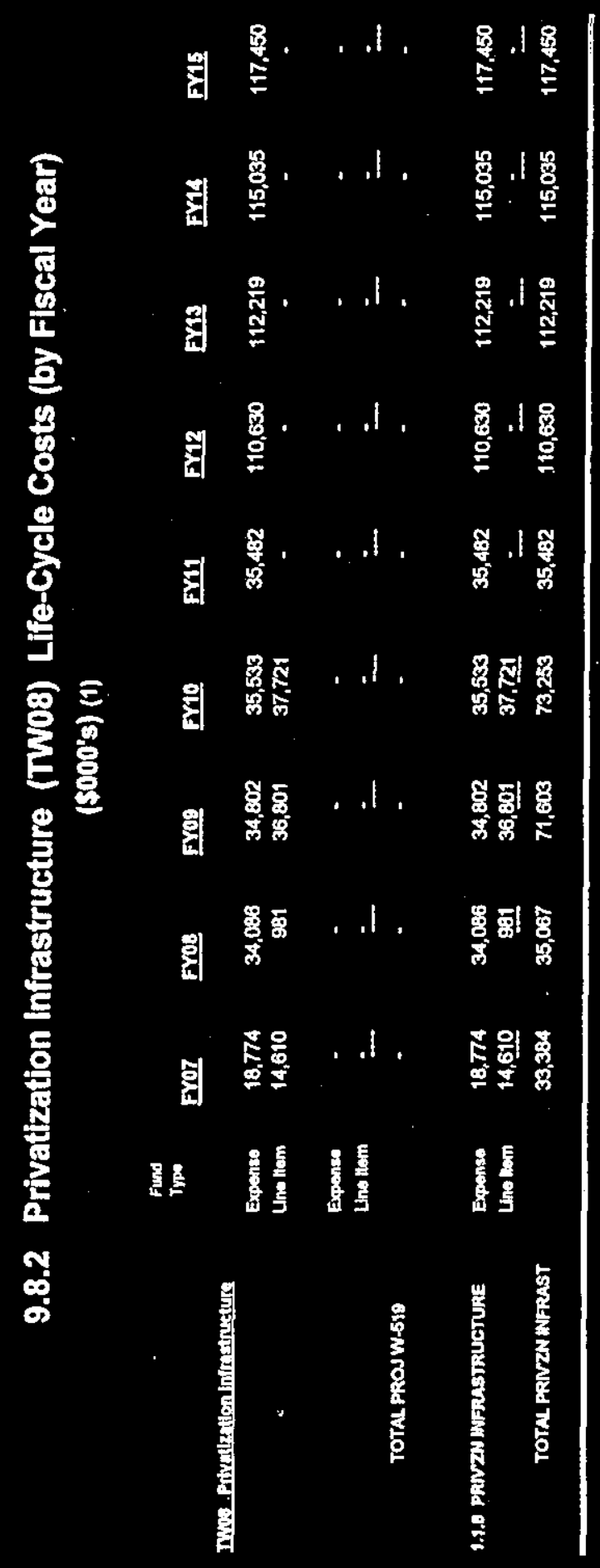




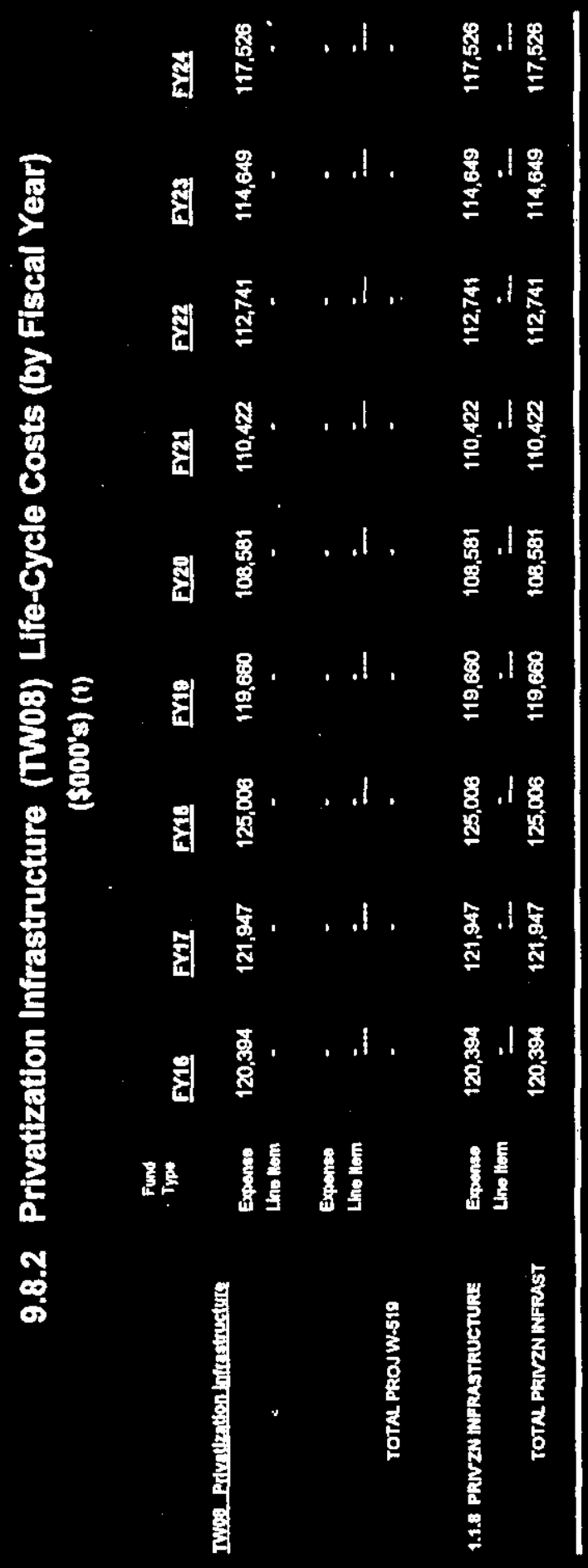




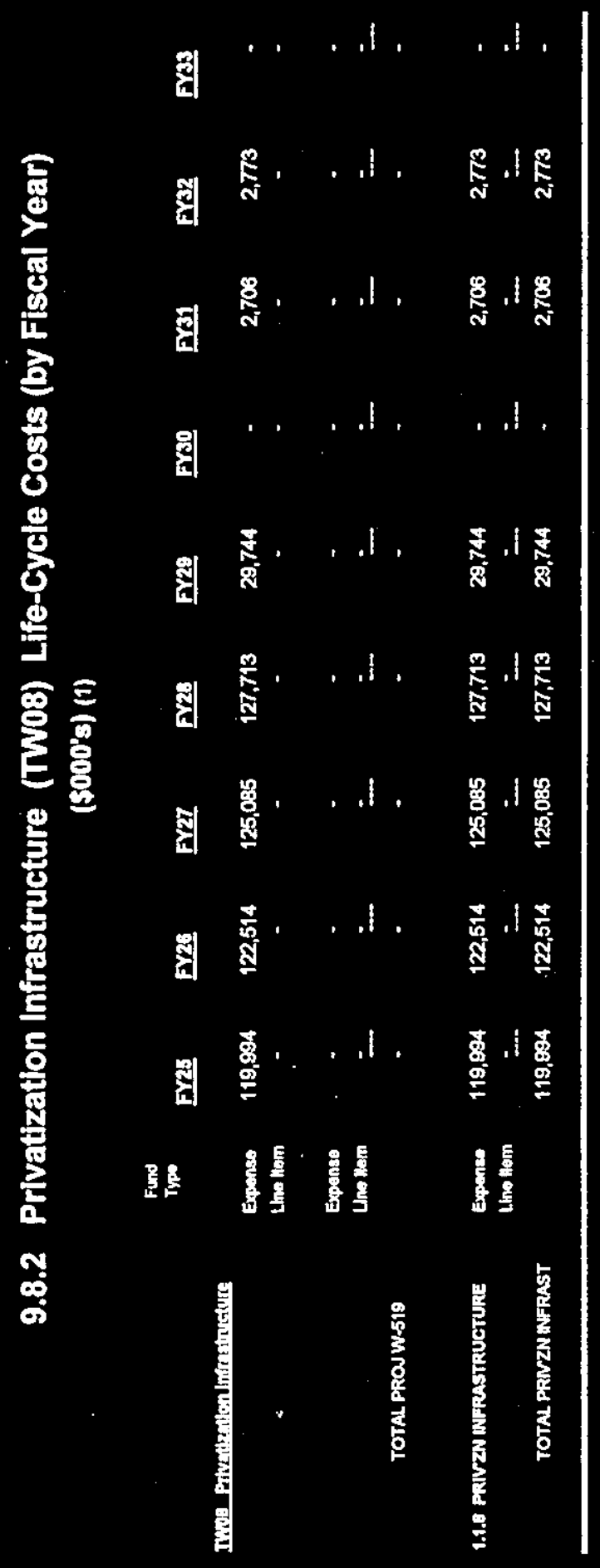


RPP-5044

9-76

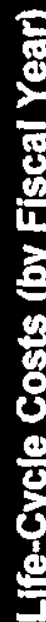

후요용

옹

5

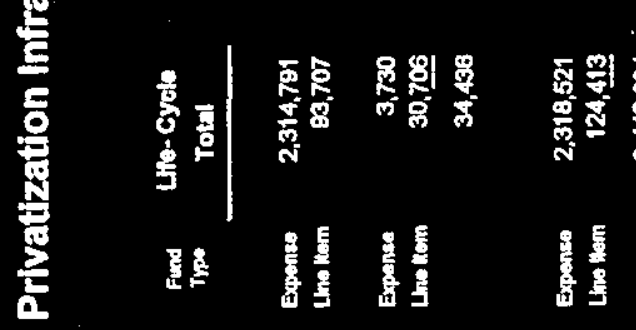

్ㅜㅇ
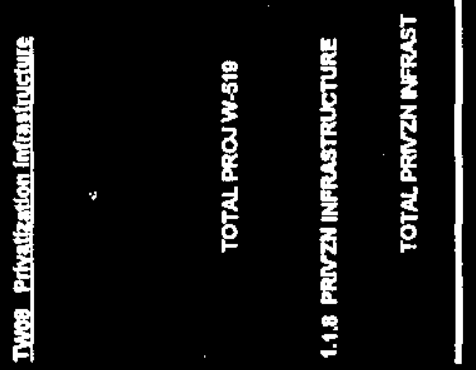
9.8.3 Privatization Infrastructure (TW08) Budget Profile By Month (Execution Year) (1) (\$000's)

\begin{tabular}{|c|c|c|c|c|c|c|c|c|c|c|c|c|c|c|c|}
\hline Lexcis Iitle & & $\begin{array}{l}\text { Fund } \\
\text { Ivet }\end{array}$ & 204 & How & Des & $\underline{\text { den }}$ & Fteb & Marr & Axx & تمس & teng & swiv & An & sepp & I0네 \\
\hline 1.1.8.1.1.1 & Ph 1 infrastneture(W-519) & $\begin{array}{l}\text { Expense } \\
\text { Lne Hem }\end{array}$ & $\begin{array}{l}219 \\
481\end{array}$ & $\begin{array}{l}275 \\
759 \\
\end{array}$ & $\begin{array}{l}298 \\
651 \\
\end{array}$ & $\begin{array}{l}308 \\
\underline{681} \\
\underline{1}\end{array}$ & $\begin{array}{l}272 \\
675\end{array}$ & $\begin{array}{r}240 \\
1,343 \\
\end{array}$ & $\begin{array}{r}210 \\
1.373 \\
\end{array}$ & $\begin{array}{r}230 \\
1.522 \\
\end{array}$ & $\begin{array}{r}231 \\
1.405\end{array}$ & $\begin{array}{r}212 \\
1.147\end{array}$ & $\begin{array}{r}255 \\
1.271 \\
\end{array}$ & $\begin{array}{r}223 \\
4350 \\
\end{array}$ & $\begin{array}{r}2,973 \\
15,638 \\
\end{array}$ \\
\hline \multirow[t]{2}{*}{ Tothls } & & $\begin{array}{l}\text { Exponse } \\
\text { Line ltom }\end{array}$ & $\begin{array}{l}219 \\
4151 \\
\end{array}$ & $\begin{array}{l}275 \\
759\end{array}$ & $\begin{array}{l}298 \\
651\end{array}$ & $\begin{array}{l}308 \\
681\end{array}$ & $\begin{array}{l}272 \\
\underline{675} \\
\end{array}$ & $\begin{array}{r}240 \\
1,343 \\
\end{array}$ & $\begin{array}{r}210 \\
1,373 \\
\end{array}$ & $\begin{array}{r}230 \\
1522 \\
\end{array}$ & $\begin{array}{r}231 \\
1405 \\
\end{array}$ & $\begin{array}{r}212 \\
1.147 \\
\end{array}$ & $\begin{array}{r}255 \\
1,271 \\
\end{array}$ & $\begin{array}{r}223 \\
4850 \\
\end{array}$ & $\begin{array}{r}2,973 \\
15,638 \\
\end{array}$ \\
\hline & & & 600 & 1.034 & 949 & $\mathbf{9 8 9}$ & 947 & 1,583 & 1,583 & 1.752 & 1,636 & 1.359 & 1,526 & 4,573 & 18,611 \\
\hline
\end{tabular}




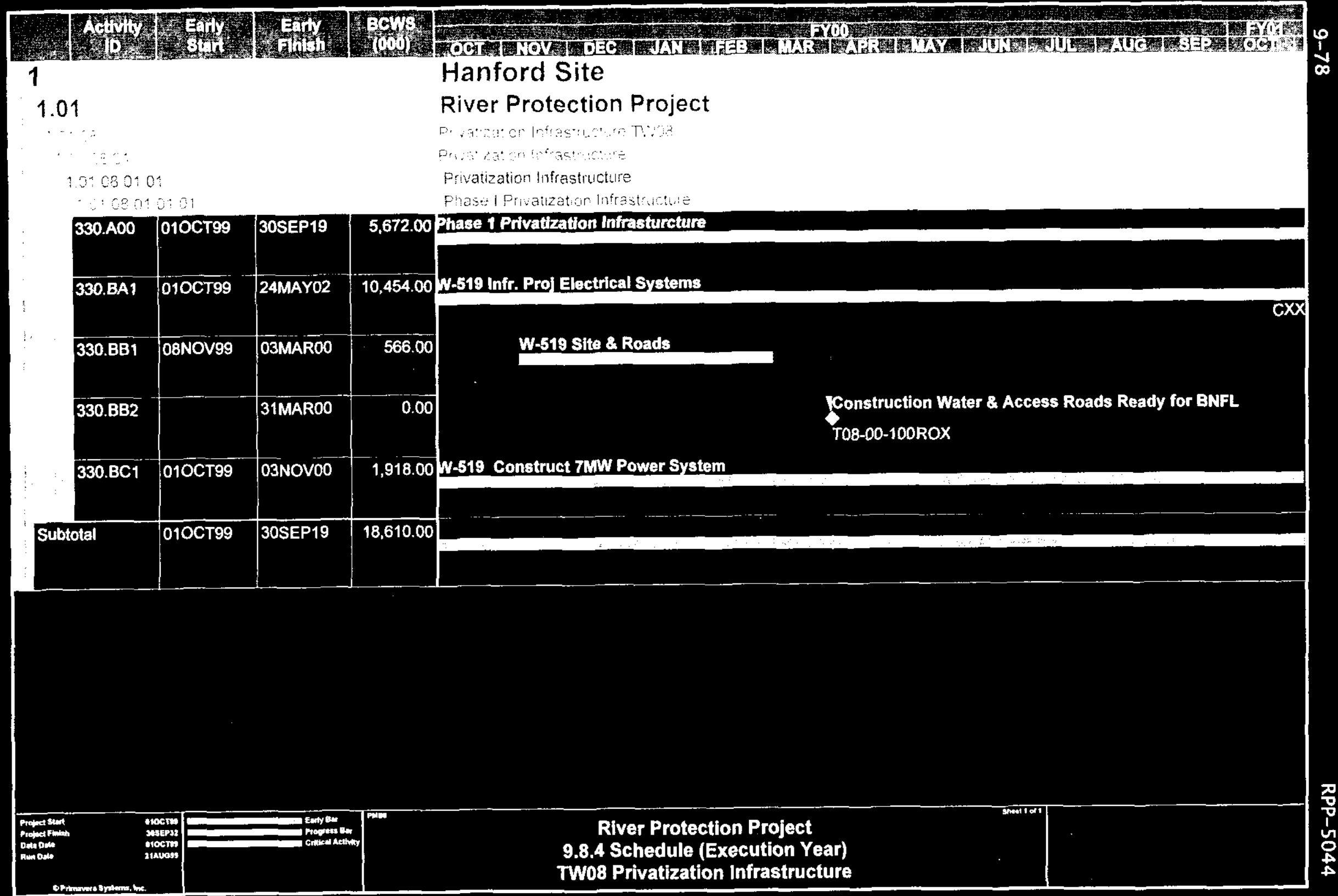




\subsubsection{Milestone Log (Execution Year)}

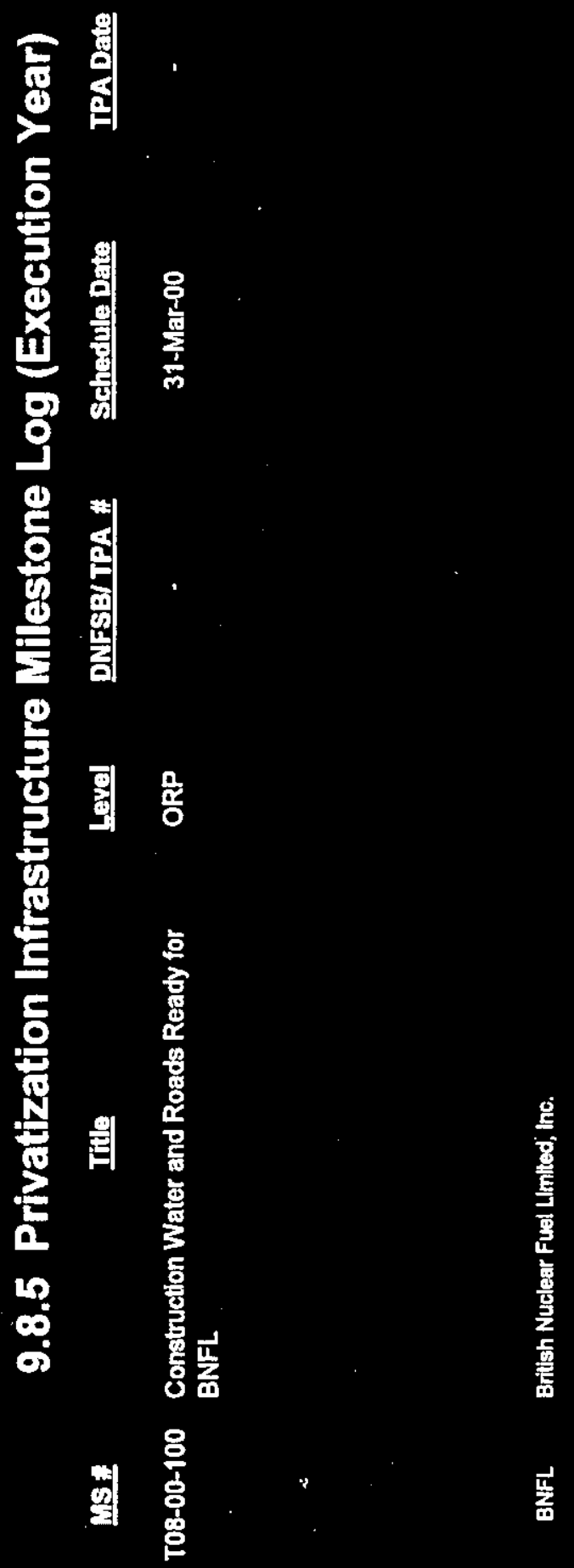


RPP-5044

9-80

This page intentionally left blank. 


\subsection{IMMOBILIZED TANK WASTE STORAGE AND DISPOSAL (TW09)}

\subsubsection{Mission Statement}

The Immobilized Tank Waste Storage and Disposal project will provide safe storage and final near-surface disposal on the Hanford Site for immobilized low-activity tank waste (ILAW), and interim storage for immobilized high level waste (IHLW).

The ILAW project will be complete when the ILAW is disposed of on the Hanford Site, long-term surveillance and monitoring of the ILAW disposal site is ongoing, interim storage facilities have been decontaminated and decommissioned, and closure barriers have been placed over disposal sites. The ILAW storage and disposal facilities will accept the ILAW from the RPP Privatization Contractor. The ILAW waste packages will be placed in near-surface disposal facilities. The near-surface disposal systems and the waste package must meet DOE regulatory requirements for near-surface disposal of lowlevel waste.

The IHLW Interim Storage Facility will receive IHLW and transport it to a Canister Storage Building (CSB), where the product will be stored until it is shipped to a geologic repository. Storage of the Phase 1 product in the CSB will consolidate the high-level waste in one area and provide a safe environmentally sound storage of the IHLW product. HLW Interim Storage will provide additional storage capacity during Phase $1 B$ and 2. In addition, HLW interim storage will provide loadout capability for shipment of IHLW canisters to a geologic repository.

IHLW and ILAW waste receipts are currently planned to commence in 2007 and 2008, respectively. 


\begin{tabular}{|c|c|c|c|c|c|c|c|c|c|c|c|}
\hline $9.9 .2 \mathrm{lmn}$ & 200 & ste & $\mathrm{rag}$ & ad Dis & sal (1) & & $\mathrm{e}-\mathrm{Cyo}$ & $\cos$ & $y F$ & Year & \\
\hline & Fund & FYer & Exen & Eree & Expe & EYa1 & EYo: & EYos & EYou & EYop & EYos \\
\hline 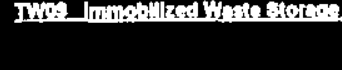 & Expen & 4,968 & 11,303 & $\mathbf{5 , 3 3 1}$ & 7,608 & 7,648 & 7,512 & 8,743 & 17,820 & 15,660 & 7,342 \\
\hline . & Une lam & - & - & - & - & - & - & - & & - & 19,489 \\
\hline & Expenso & - & - & - & - & 715 & 2.177 & 1,518 & 1,516 & 2,201 & 1,018 \\
\hline & & - & - & $\ldots$ & $\ldots$ & - & - & $-0,09$ & $33,1 / 8$ & 10,12 & 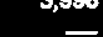 \\
\hline тотAL W-165 & & - & - & - & - & 715 & 2,177 & 5,773 & 14,695 & 18,913 & 5,016 \\
\hline & Exponse & - & - & - & 1,528 & 1,530 & 1,817 & 2,265 & 2,643 & 2,739 & 1,025 \\
\hline & Lno ken & - & - & - & - & 4,500 & 16,428 & 35,950 & 22,672 & 1,750 & - \\
\hline TOTAL W-AB & & - & - & - & 1,528 & 6,031 & 18,245 & 38,215 & 25,518 & 4,490 & 1,025 \\
\hline & Expenso & - & - & & - & - & 89 : & 14 & 2,473 & 4,411 & 1,937 \\
\hline & Lhow Kam & - & • & - & - & - & - & - & - & 239 & 5,573 \\
\hline & & - & - & - & - & - & - & 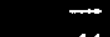 & $\overline{7}$ & - & $\overline{-}$ \\
\hline Tork. Wh-520 & & - & - & • & 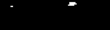 & - & 89. & 14 & $2,4 / 6$ & 4,001 & (1, \\
\hline 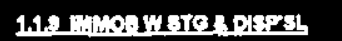 & Expentes & 4,968 & 11,303 & 5,331 & 9,136 & 9,894 & 11,594 & 13,540 & 24,758 & 25,032 & 11,322 \\
\hline & Lne them & & & & & 4,500 & 16,428 & 40,204 & 35,851 & 18,702 & 29,070 \\
\hline тотм мйем сто & & $\sqrt{4088}$ & 115303 & $5 \overline{531}$ & 8.136 & 14394 & $28, \overline{022}$ & $53, \overrightarrow{745}$ & 00607 & $\overline{43773}$ & $40 \overline{392}$ \\
\hline
\end{tabular}




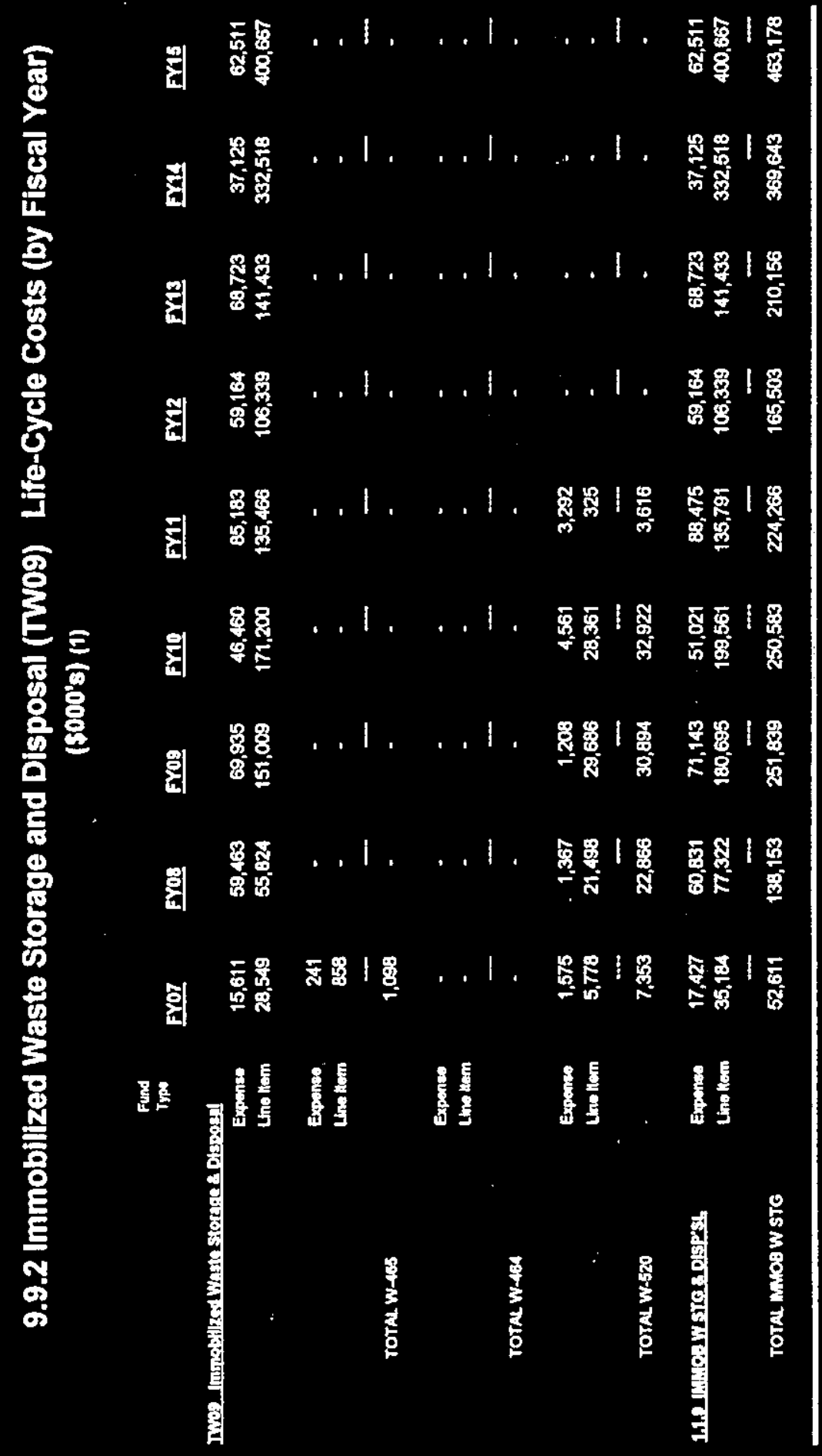


RPP-5044

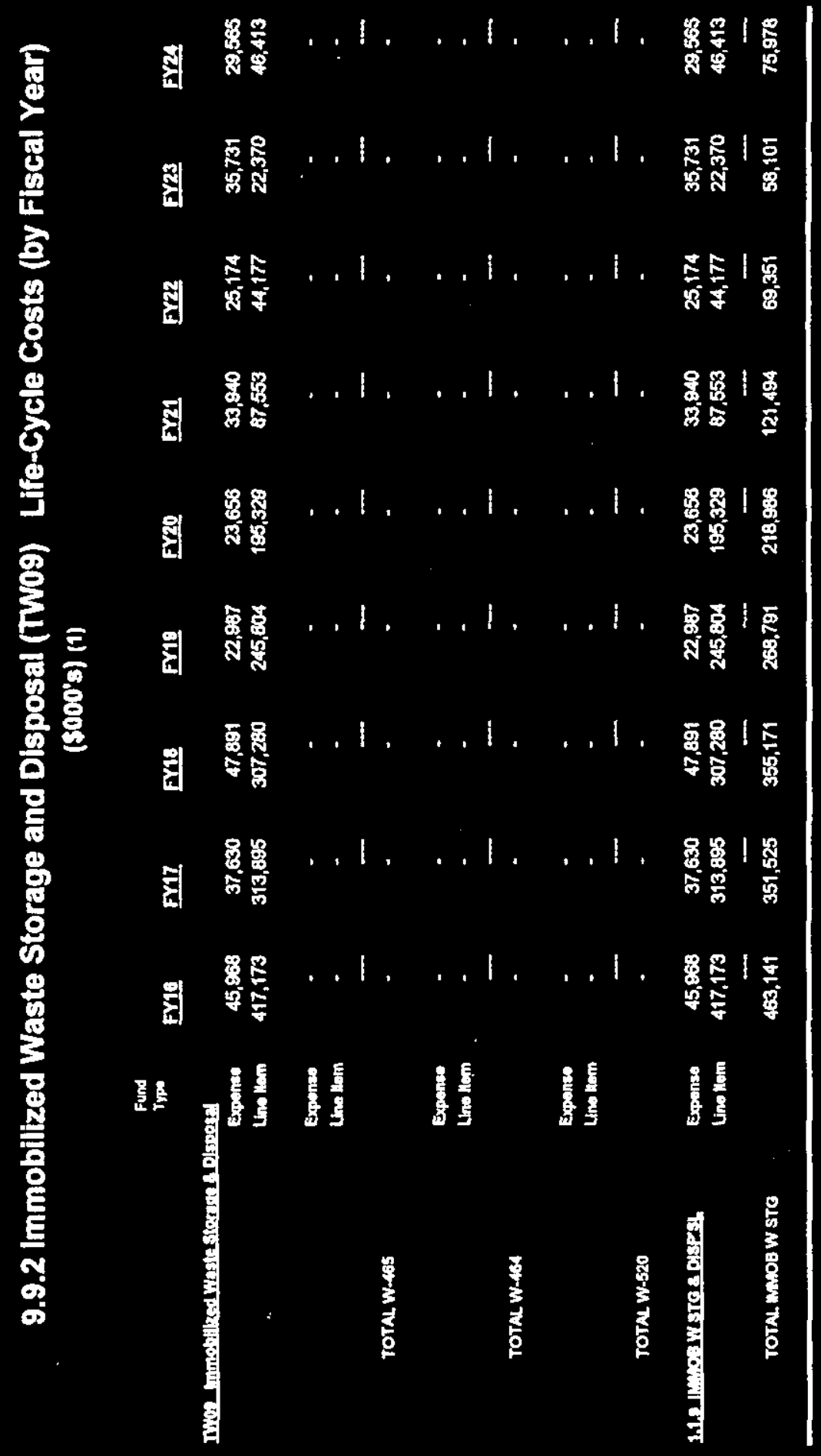




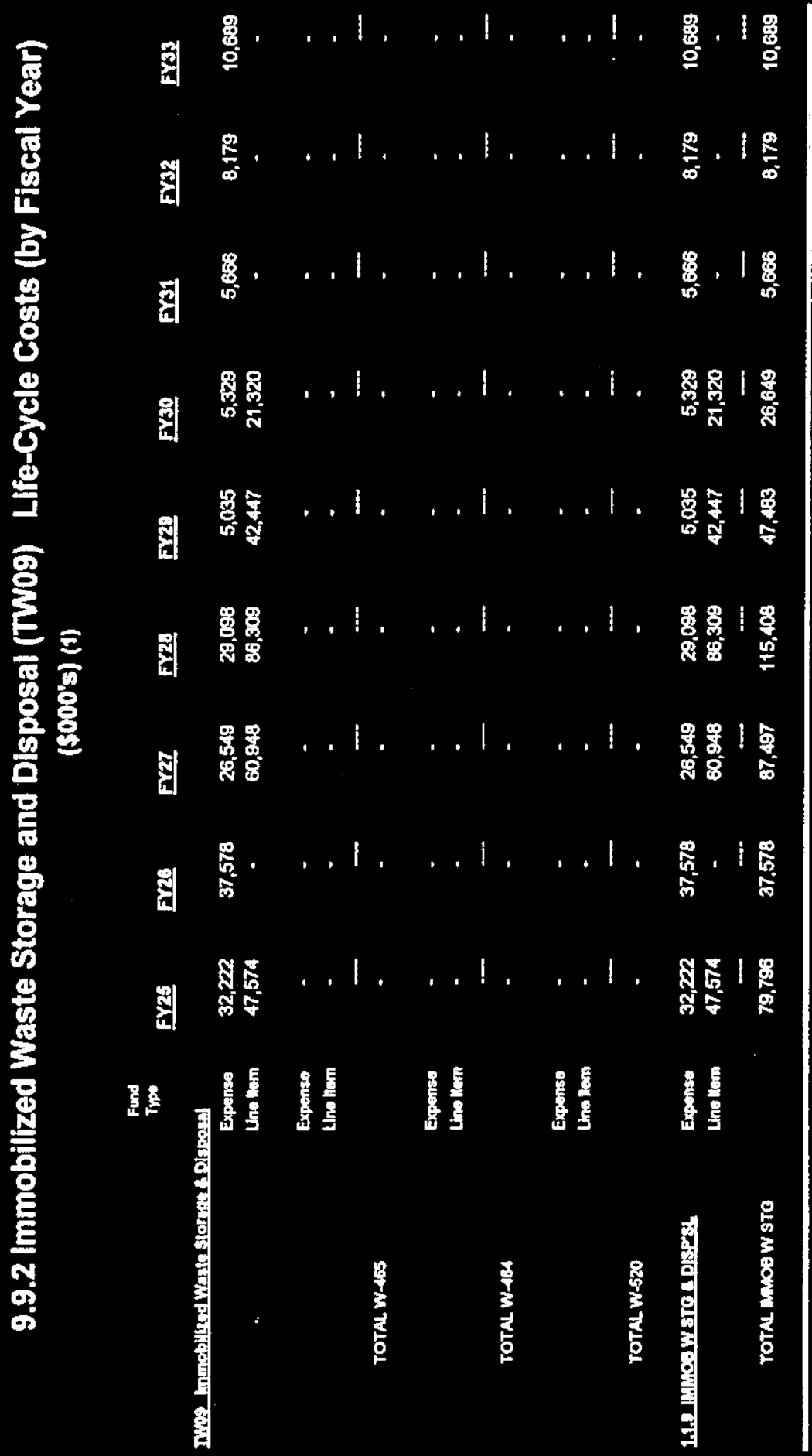


9.9.2 Immobilized Waste Storage and Disposal (TW09) Life-Cycle Costs (by Fiscal Year) (5000's) (1)

\begin{tabular}{|c|c|c|c|c|c|c|c|c|c|c|}
\hline & $\begin{array}{l}\text { Fund } \\
T_{\text {Tine }}\end{array}$ & EYM & FY35 & EYas & FY37 & FY33 & FYs: & $\mathbf{E Y}$ & Fus & Fut? \\
\hline \multicolumn{11}{|c|}{ 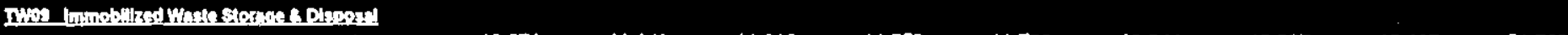 } \\
\hline & Expentas & 10,871 & 11,143 & 11,316 & 11,553 & 11,786 & 12,044 & 12,297 & 12,187 & 51,768 \\
\hline \multirow[t]{4}{*}{.} & Lher Mom & - & - & - & - & - & - & - & - & - \\
\hline & Exponse & - & - & - & - & - & - & - & - & - \\
\hline & Lino hom & - & - & - & - & - & - & - & - & - \\
\hline & & سم & - & - & $一$ & - & 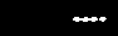 & - & - & - \\
\hline \multirow[t]{4}{*}{ TOTAL W-465 } & & - & - & - & - & - & - & - & - & - \\
\hline & Expense & - & * & - & - & - & - & - & - & - \\
\hline & Lino inom & - & - & - & - & - & - & - & - & - \\
\hline & & - & - & 一 & $\ldots$ & $\cdots$ & - & 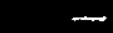 & - & - \\
\hline \multirow[t]{4}{*}{ TOTAL W-4EA } & & - & - & - & - & - & - & - & - & - \\
\hline & Exponse & - & - & - & - & - & - & - & - & - \\
\hline & Line kem & - & - & - & - & - & - & - & - & - \\
\hline & & - & $\rightarrow$ & - & $\cdots$ & - & $\cdots$ & م- & 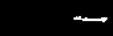 & $\leftarrow$ \\
\hline TOTNL W-520 & & - & - & - & - & - & - & - & - & - \\
\hline \multirow[t]{3}{*}{ 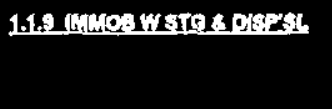 } & Exponses & 10,871 & 11,143 & 11,316 & 11,553 & 11,796 & 12,044 & 12,297 & 12,187 & 51,768 \\
\hline & Ling Hom & - & - & - & - & - & - & - & - & - \\
\hline & & - & - & $\infty$ & - & - & $\cdots$ & 一 & - & - \\
\hline TOTAL MAOB W STO & & 10,871 & 11,143 & 11,318 & 11,553 & 11,793 & 12,044 & 12,297 & 12,187 & 51,768 \\
\hline
\end{tabular}

(1) All dollers displayed contein applicablo escalation 


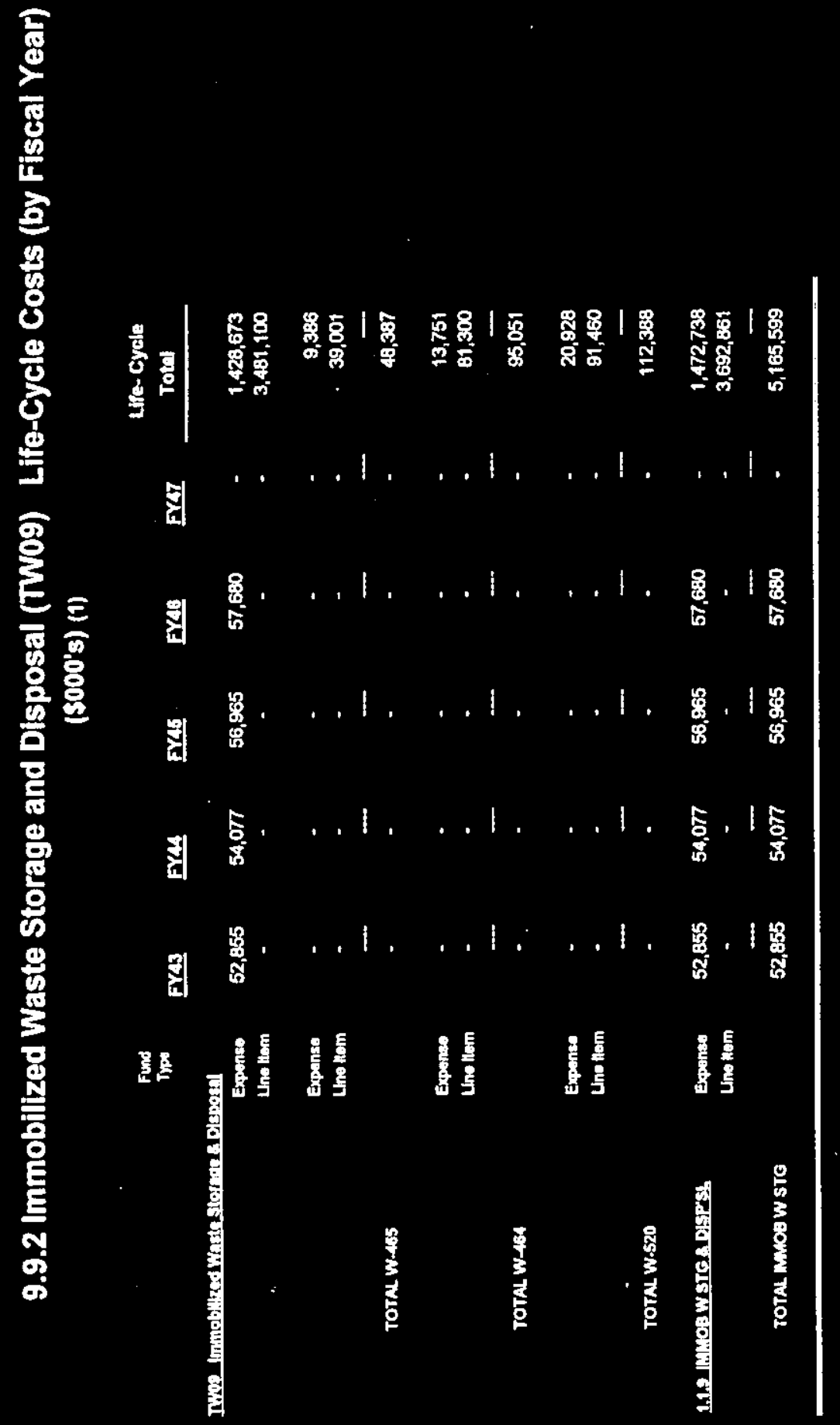


9.9.3 Budget Profile by Month (Execution Year)

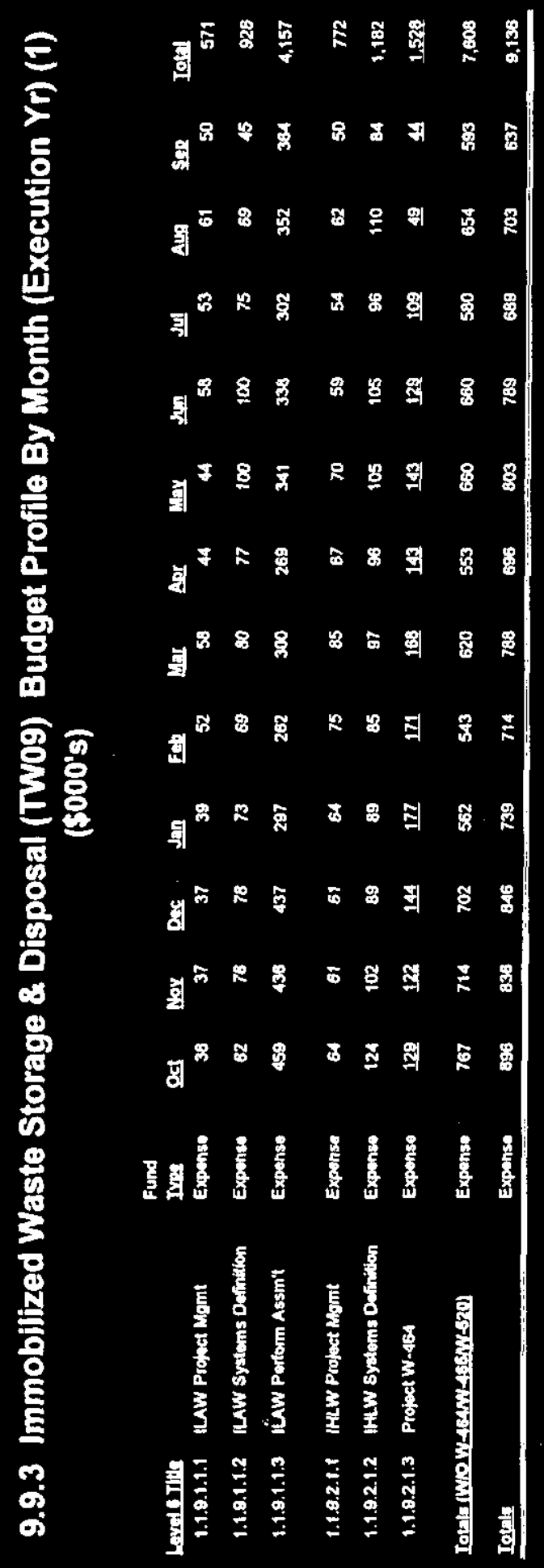




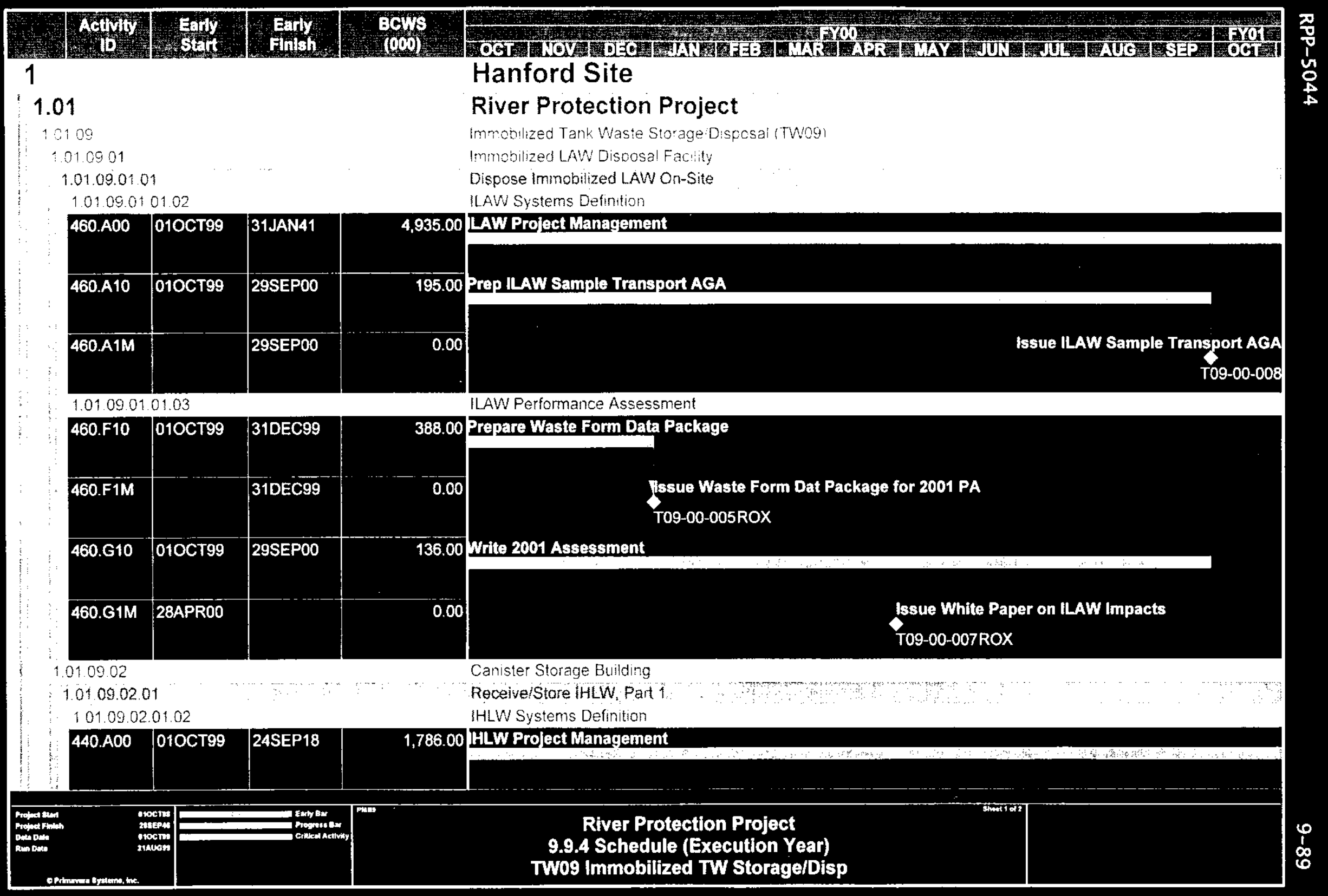









\subsubsection{Milestone Log (Execution Year)}

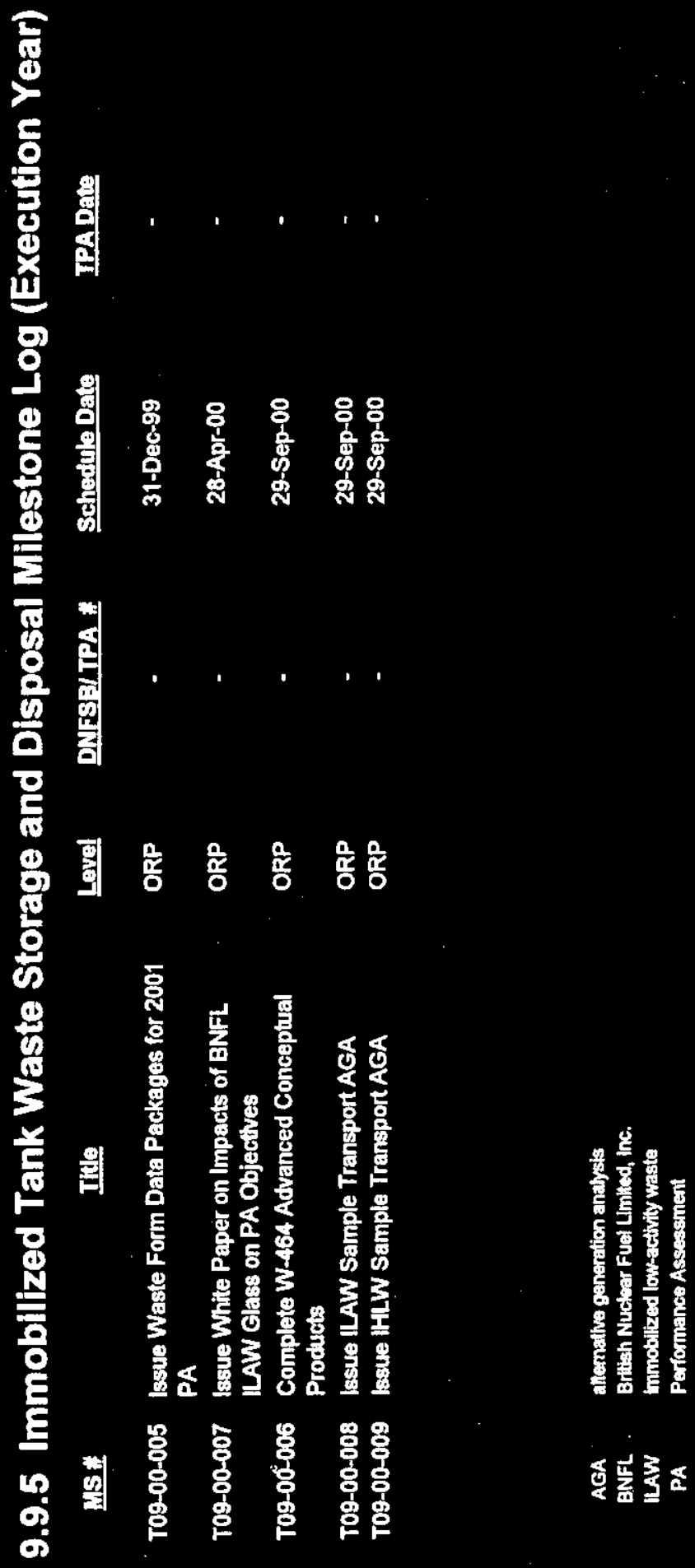


RPP-5044

9-92

This page intentionally left blank. 


\subsection{RPP MANAGEMENT SUPPORT (TW10)}

\subsubsection{Mission Statement}

The RPP Management Support Project (MSP) provides program management services and oversight that sustain RPP integration and control. Practical products of MSP work are systems developed, improved, deployed, and maintained to structure program strategy, direction and business management in support of the RPP technical functions, waste storage and waste disposal. Primary MSP functions include the following:

- Executive management and strategic planning

Systems engineering to support risk and decision management and ongoing evolution of the RPP technical bases

Administration of a core program and crosscutting services to ensure environmental, safety, health, and quality assurance compliance to all regulatory and contractual requirements applicable for the RPP

Life-cycle project management that includes work to establish and maintain technical, cost, and schedule elements for the RPP baseline. 
RPP-5044

$$
\text { 9-94 }
$$

9.10.2 Life-Cycle Costs by Fiscal Year

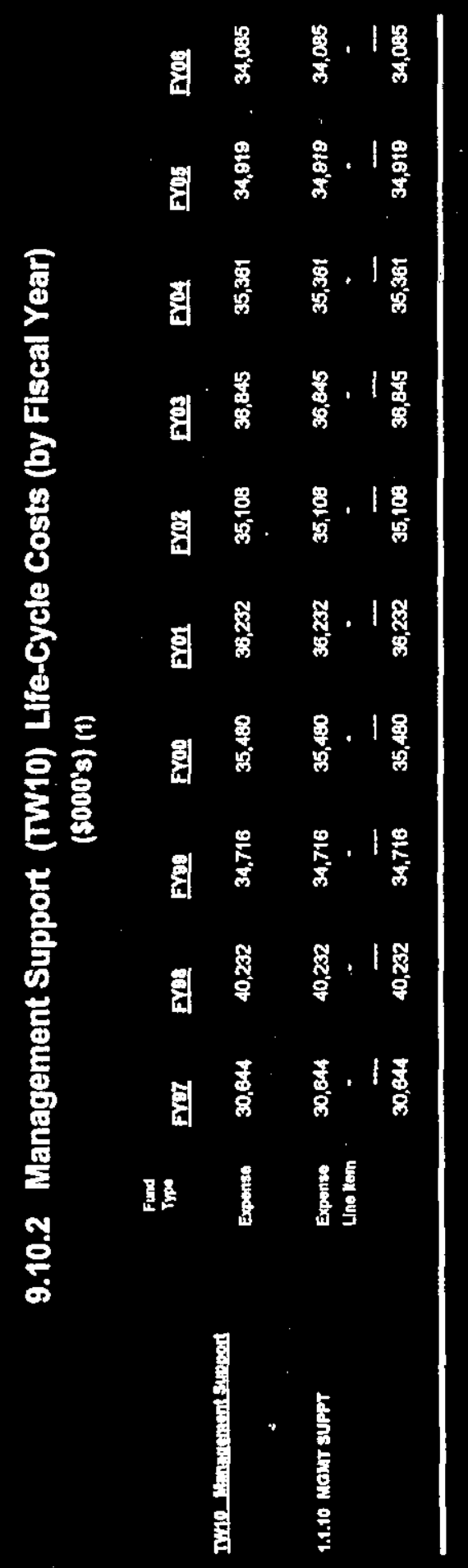




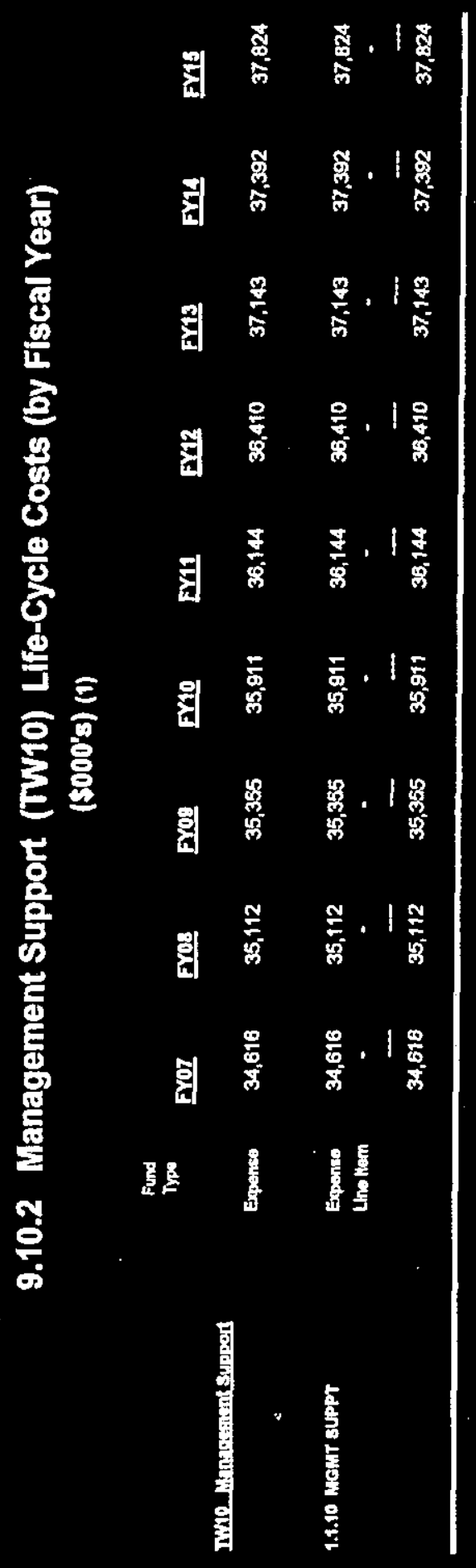


RPP-5044

9-96

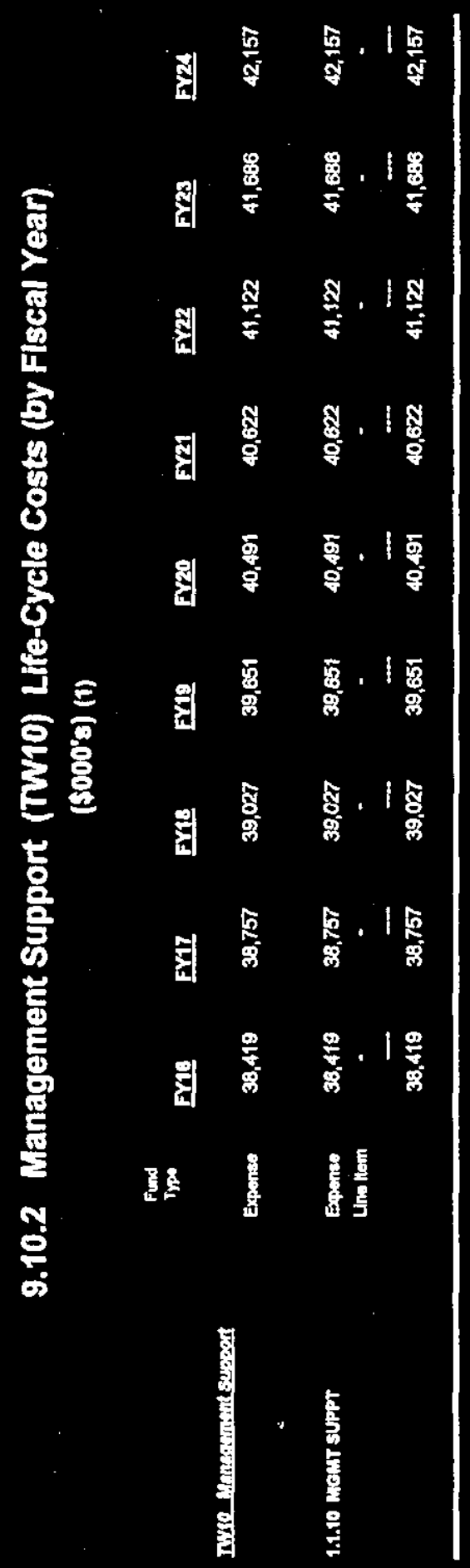




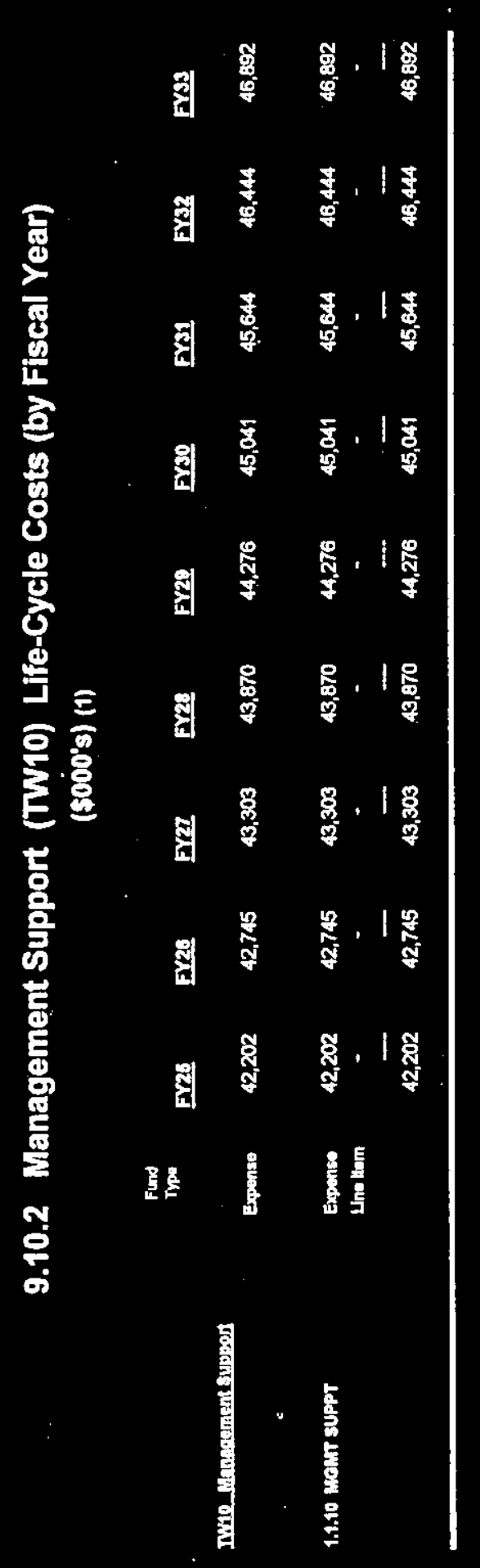


RPP-5044

9-98

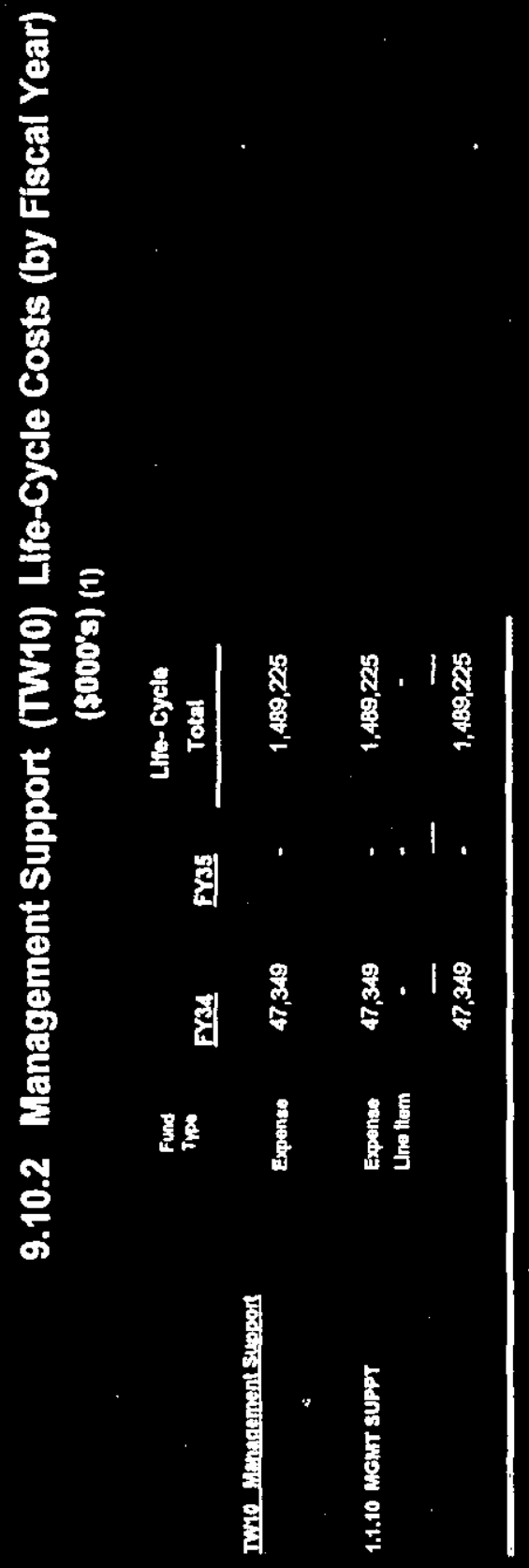

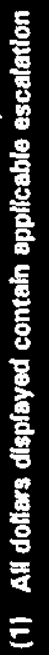




\subsubsection{Budget Profile by Month (Execution Year)}

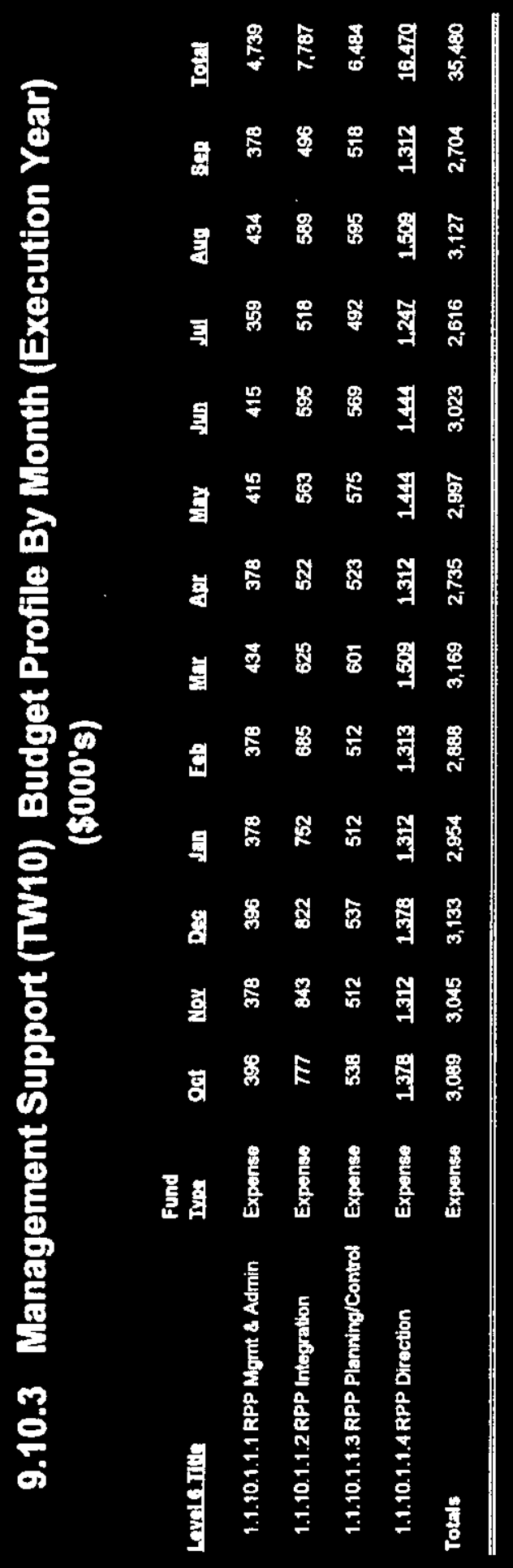




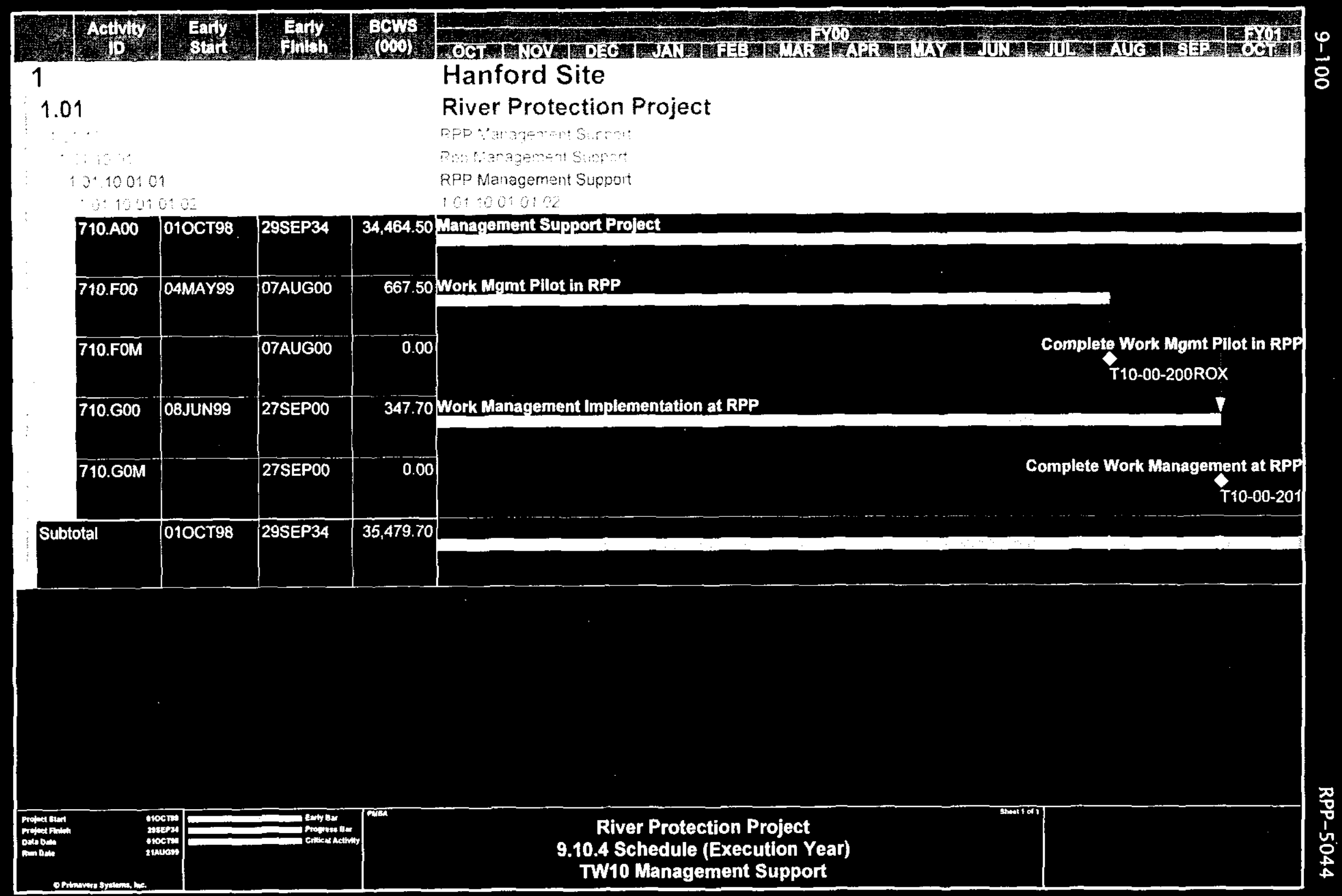




\subsubsection{Milestone Log (Execution Year)}

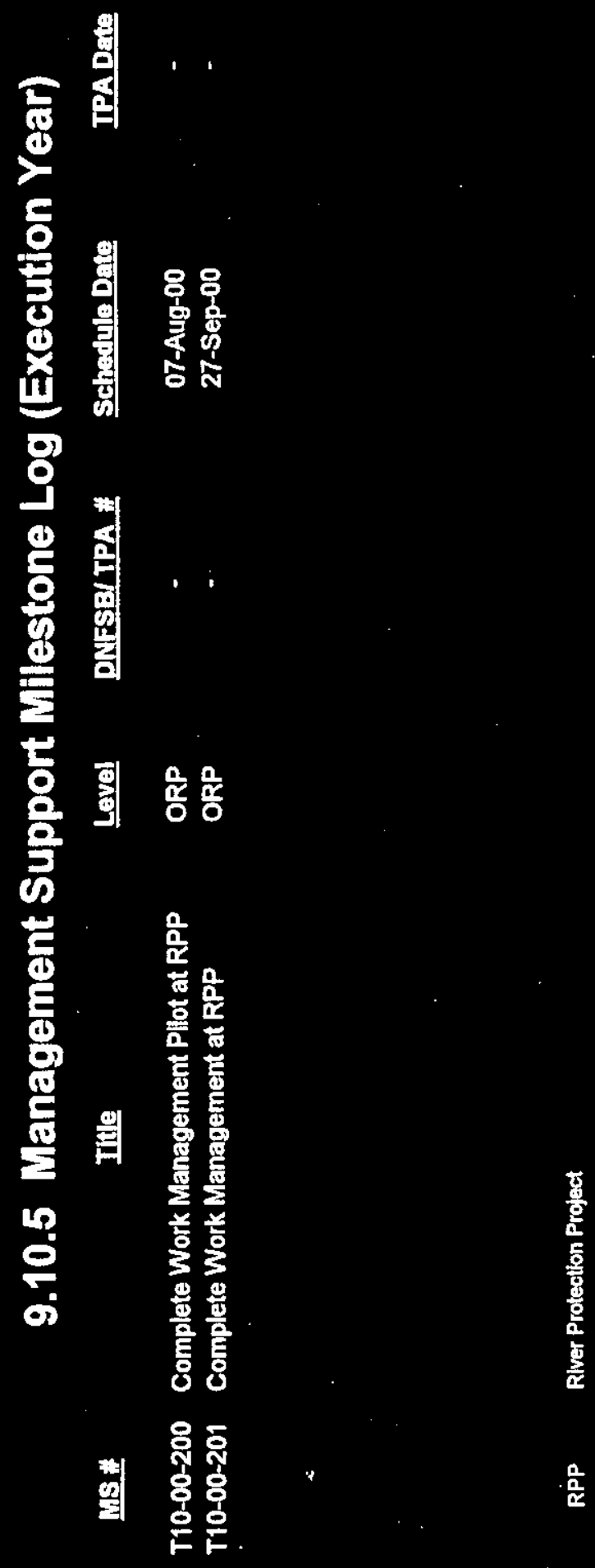


RPP-5044

9-102

This page intentionally left blank. 


\subsection{REFERENCES}

Acree, C. D., Jr., 1996, Tank Waste Remediation System Mission Analysis, HNF-SD-WM-MAR-008, Rev. 1, Lockheed Martin Hanford Corporation for Fluor Daniel Hanford, Inc., Richland, Washington.

DOE, 1993, Tank Waste Remediation System Justification of Mission Need, U.S. Department of Energy, Washington, D.C.

DOE, 1996, Tank Waste Remediation System, Hanford Site, Final Environmental Impact Statement, DOE/EIS-0189, U.S. Department of Energy, Washington, D.C.

Ecology, EPA, and DOE, 1989, Hanford Federal Facility Agreement and Consent Order, Washington State Department of Ecology, U.S. Environmental Protection Agency, U.S. Department of Energy, Olympia, Washington.

Ecology, EPA, and DOE, 1994, Hanford Federal Facility Agreement and Consent Order, two volumes, Washington State Department of Ecology, U.S. Environmental Protection Agency, U.S. Department of Energy, Olympia, Washington.

Ecology, EPA, and DOE, 1996, Hanford Federal Facility Agreement and Consent Order, as amended, Washington State Department of Ecology, U.S. Environmental Protection Agency, U.S. Department of Energy, Olympia, Washington.

LMC-MD-018, FY 2000 Planning, Work Authorization, and Cost Collection Guidance, Lockheed Martin Hanford Corporation, Richland, Washington

LMHC, 1998, Tank Waste Remediation System Final Safety Analysis Report, HNF-SD-WM-SAR-067, Rev. 0, prepared by Lockheed Martin Hanford Corporation for Fluor Daniel Hanford, Inc., Richland, Washington.

National Environmental Policy Act of 1969, 42 USC 4321, et seq.

Nuclear Waste Policy Act of 1982, 42 USC 10101, et seq.

Resource Conservation and Recovery Act of 1976, 42 USC 6901, et seq.

"Safety Measures for Waste Tanks at Hanford Nuclear Reservation," Public Law 101-510.

Strom Thurmond National Defense Authorization Act for Fiscal Year 1999 
RPP-5044

10-2

This page intentionally left blank. 
Appendix A

TYPICAL FISCAL YEAR CALENDAR 
RPP-5044

A-2

This page intentionally left blank. 


\section{Typical Fiscal Year (FY) Calendar}

FY Start

1. FY Work Execution to Approved Baseline Work Plans(M YWPs and AWPs) Implementing the Site EM Specification

2. Anntral Planning Process

a. Review HSP for Changes

* No/Minor Changes

* Major Changes (seldom)

b. Mission Planning Guidance for Life-

Cycle, Long-Range Budget Planning

c. Planning \& Analysis

d. FY+1 President's Budget Submittal

e. IPUBudget Preparation

f. FY+2 Budget to HQ

1.

Work Execution

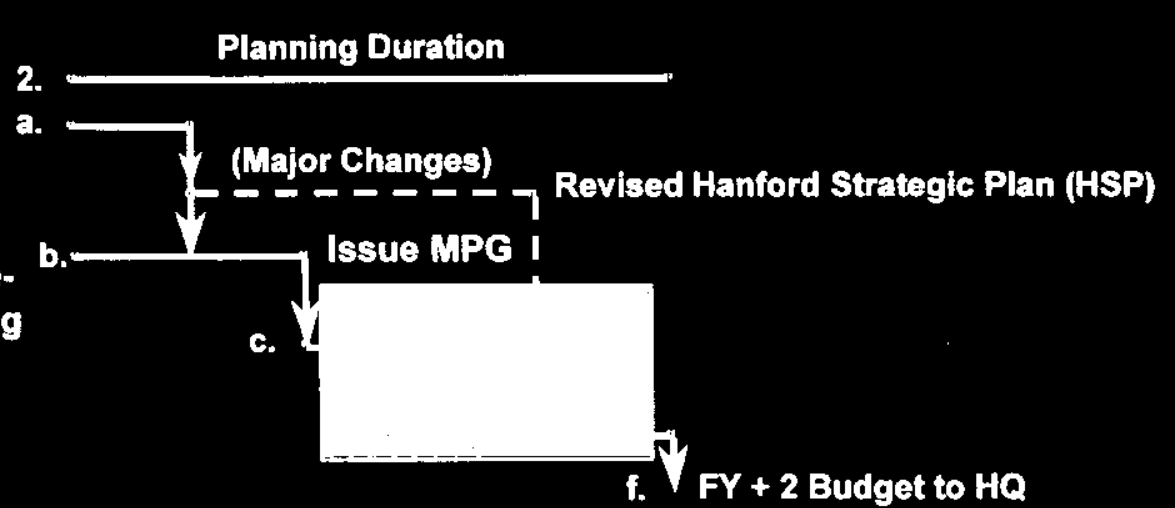

- Project Baseline Summaries

- With Integrated Priority List (IPL)

- FY Baseline Update As Needed (WYWPs)

- 2006 Plan Update

3. Annual Baseline Updating Process

a. FY+2 HQ Budget Meeting Results

b. Develop 8 Issue Baseline Update Guidance (BUG)

c. FY+1 Appropriation Known

d. Revised Baseline Preparation As Needed

e. Approved Work Plans with FY+1 Work Authorization

- Baseline Update As Needed

- 2006 Plan Update As Needed

Primary Tribal and Public Involvement

3. Baseline Updating Duration

a. X Budget Mitg Results

b.

Regulatory Involvement Ongoing

d.

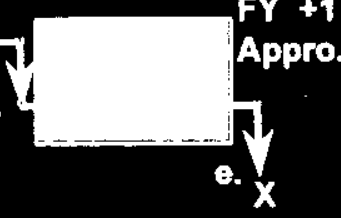

FY +1

Approved

FY +1 Work 
RPP-5044

A-4

This page intentionally left blank. 
Appendix B PROJECT PRIORITY LIST 
RPP-5044

B-2

This page intentionally left blank 
RPP-5044

B-3

\section{Appendix B PROJECT PRIORITY LIST}

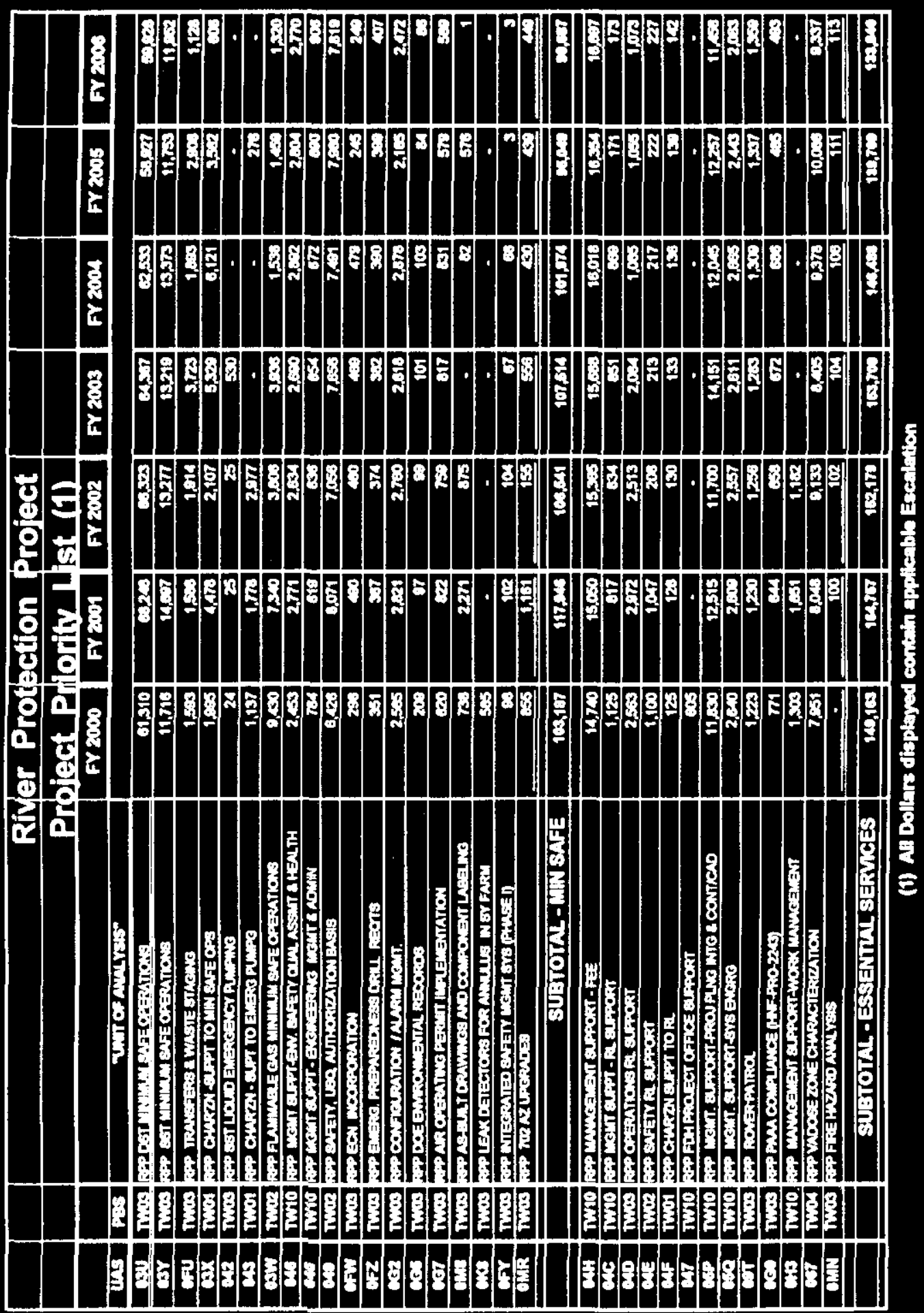




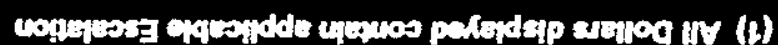

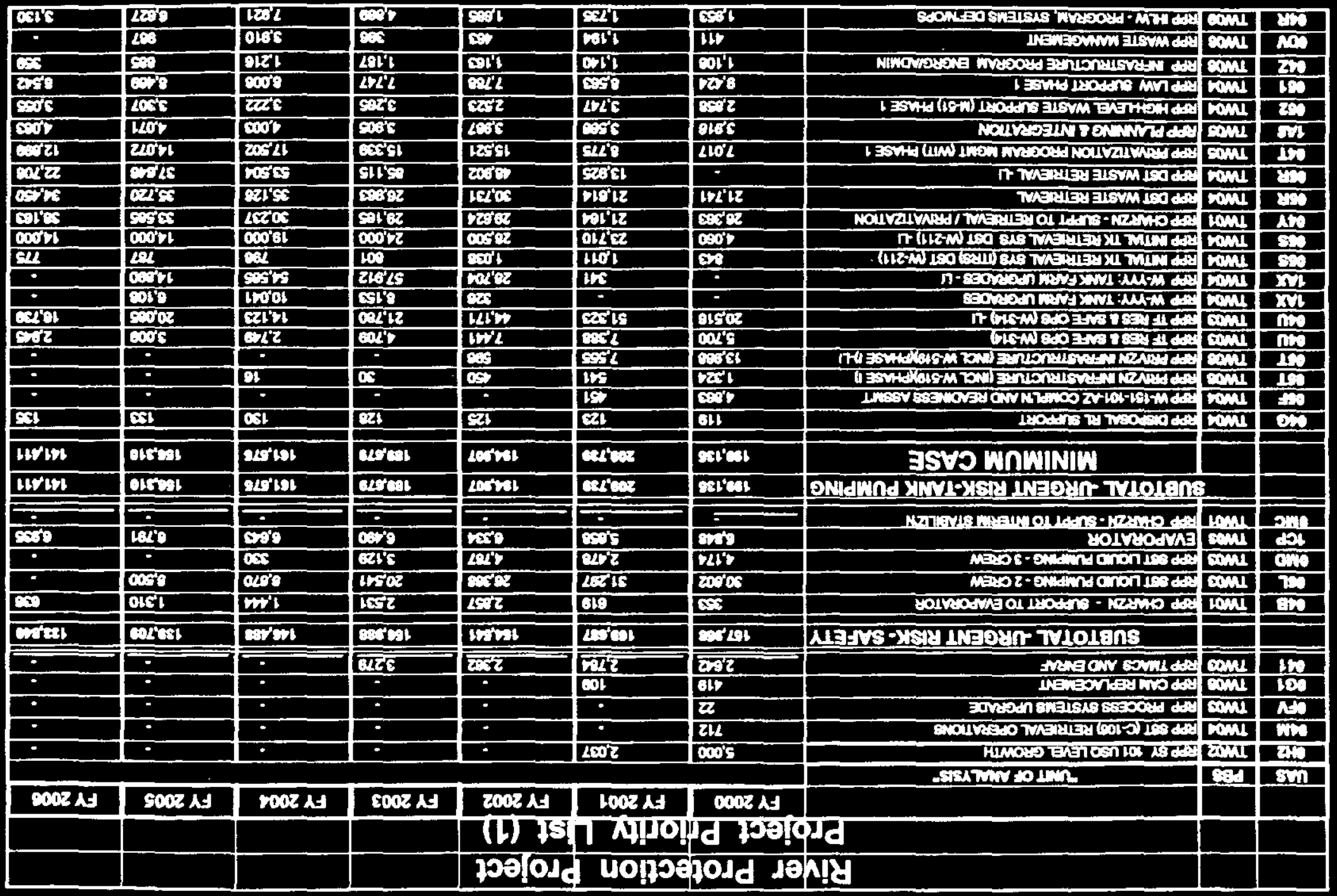




\begin{tabular}{|c|c|c|c|c|c|c|c|c|c|}
\hline & & 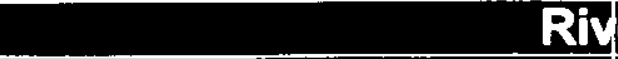 & Prot & aton & elect & & & & \\
\hline & & & FY 2000 & FY 2001 & FY 2002 & FY 2003 & FY 2004 & FY 2008 & FY 2006 \\
\hline WS & Pas & Tin of arrings & & & & & & & \\
\hline$M$ & $\mathrm{rmm}$ & 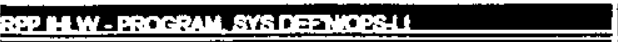 & - & $\cdot$ & 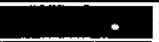 & - & - & - & $10 \mathrm{mos}$ \\
\hline ome & הורו & 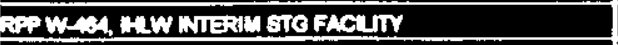 & 1,530 & 1,50 & 1817 & 2,235 & 28 & $2, \pi 0$ & 1000 \\
\hline c5 & Tim & EP W-MA, NLW WIERIM STO FACUIT U & - & 4500 & 10,400 & 35850 & 22890 & 1,750 &. \\
\hline $\mathrm{cax}$ & In & 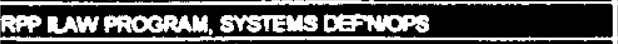 & 5005 & 5894 & 5.88 & 4.074 & 10000 & gosin & 4212 \\
\hline $\mathbf{C A x}$ & $\pi$ & 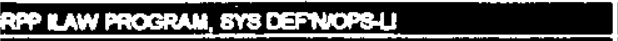 & - & - & 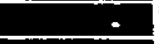 & - & $\cdot$ & - &. \\
\hline Orill & In: & 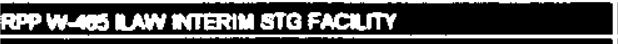 & - & 715 & 2,17 & 1,510 & 1.518 & 2201 & 1,018 \\
\hline 1: & To & 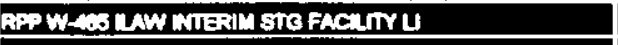 & - & $\cdot$ & $\therefore$ & 4,254 & 13,179 & 10,712 & 300 \\
\hline c3il & $\pi$ & 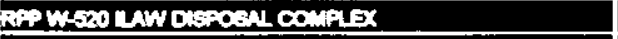 & - & - & $\theta$ & 14 & 2,473 & 4,411 & 1.937 \\
\hline Cal & Tes & 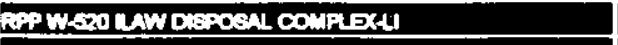 & - & $\therefore$ & - & - & - & $2 \times 3$ & 5573 \\
\hline Ma & Trim & 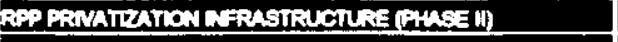 & - & 715 & 4805 & $\operatorname{sen}$ & 1200 & 1,311 & 180 \\
\hline ma & $\pi$ & 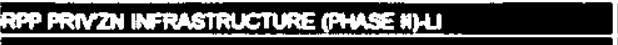 & 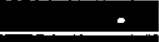 & - & $\therefore$ & - & - & 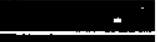 & $3 \operatorname{sen}$ \\
\hline ? & $\pi \mathrm{mad}$ & PPP TAKFANAM COOSURE & $\cdot$ & - & - & - & 1,275 & 1,345 & 1,103 \\
\hline CI & T: & 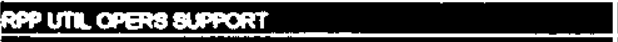 & 130 & $4 m$ & 5,904 & 5,374 & o,en & 3270 & 1030 \\
\hline Cit? & $\pi \operatorname{mos}$ & 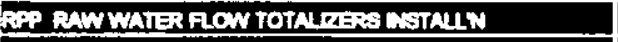 & $\cdot$ & 175 & - & 102 & $\cdot$ & $\cdot$ & $\cdot$ \\
\hline Cin & $\pi$ mos & 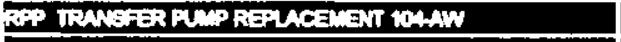 & $\cdot$ & S2 & - & . & - & - & - \\
\hline $\operatorname{cox}$ & 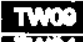 & 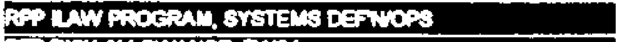 & 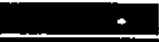 & - & 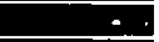 & $\cdot$ & $\div$ & - & - \\
\hline Lims & $\pi$ int & ATPER RWOWACE:TWM & $\therefore$ & $\div$ & 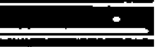 & $\div$ & $\because$ & 10.5: & 135 \\
\hline & & 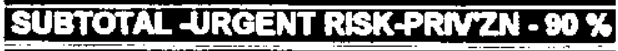 & 332,652 & 405,918 & 44873 & ET5,235 & 49,33 & 45,391 & 376,655 \\
\hline 6.0 & Twa & 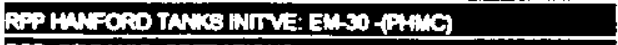 & 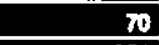 & 221 & 225 & 230 & $2 x$ & 200 & 244 \\
\hline Non & Ting & Fip oneanc opezations & $3 \mathbf{3 0}$ & 3,424 & 84 & - & - & - & - \\
\hline d & $\pi$ & 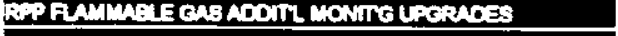 & $1: 0$ & 1,79 & - & - & - & - & - \\
\hline ene & $\pi$ & 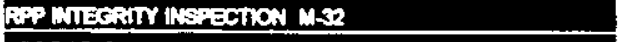 & 2.742 & 2351 & 1,932 & 1,972 & 2000 & 1.870 & $185 ?$ \\
\hline C5: & The & GPP DSI RCRA PART B APALICATKON & 58 & 284 & 47 & - & - & + & $\therefore$ \\
\hline es & $\operatorname{tin}$ & GQP WASIE $A C C$ COPTACE PROCRAM & 23 & 25 & 25 & 20 & 28 & 8 & $\theta$ \\
\hline OMF & $\operatorname{tin}$ & 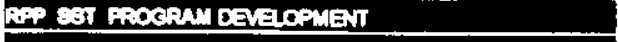 & 1,201 & 7591 & 15502 & 11,200 & 21.5es & 3520 & 23613 \\
\hline QMin & Twas & 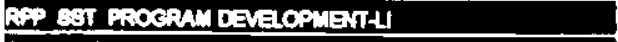 & 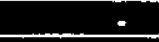 & - & $\cdot$ & . & 2,25 & $102: 3$ & 2158 \\
\hline $\operatorname{tx}$ & $\min$ & 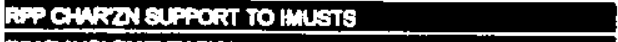 & $\therefore$ & 10,39 & 49 & 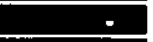 & 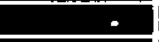 & . & - \\
\hline 8 & $\prod_{10}$ & 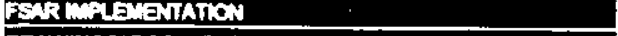 & 1,005 & 3,760 & $\operatorname{ses}$ & - & - & - & - \\
\hline as & $\min$ & DAWWGS DOCN FCR WACTME SYSTEMS & - & $\mathbf{4 3}$ & 38 & 35 & 3 & 37 & 34 \\
\hline Ots & $\min$ & 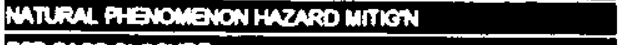 & $\therefore$ & 140 & $\cdot$ & - & - & $\therefore$ & 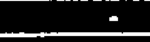 \\
\hline 60 & Twos & APP cass clogine & 504 & $\pi$ & - & - & 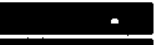 & - & - \\
\hline ens & ming & 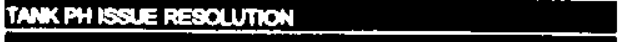 & 145 & 3007 & 89 & 470 & 610 & 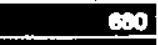 & 372 \\
\hline ens & now & FACUIY DEACTMATKON & 283 & ro & $\sin$ & $\mathbf{2 0 0}$ & 110 & 11,407 & 1,76 \\
\hline Dop & $\min$ & 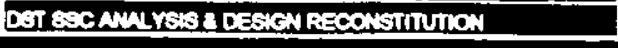 & 20 & 2,000 & 44 & 149 & 192 & 153 & 2,192 \\
\hline
\end{tabular}

(1) All Dollars dispiayed contain applicabbs Escalation 


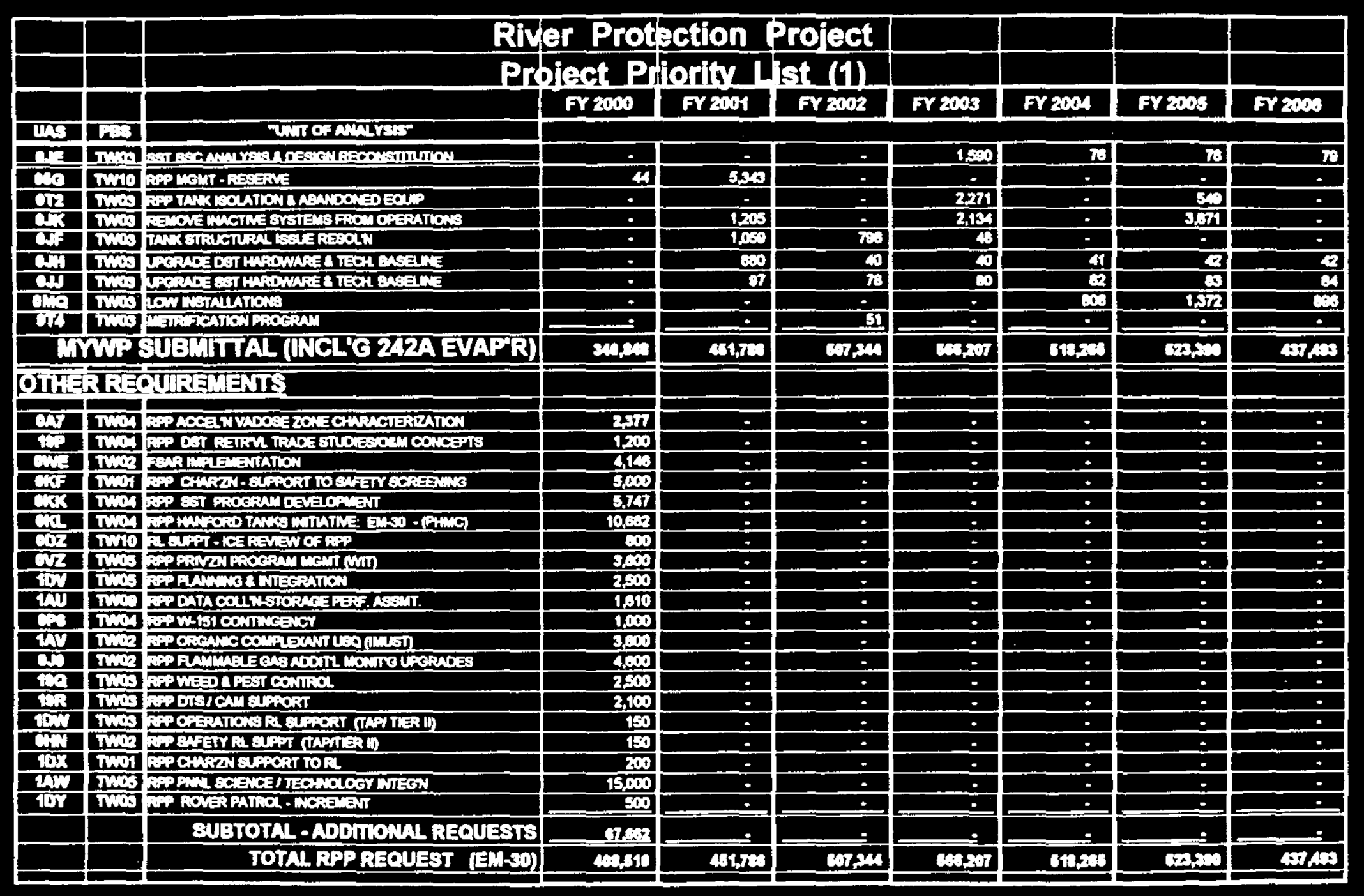

(1) All Dollars displayed combin appolleabla Escalation 


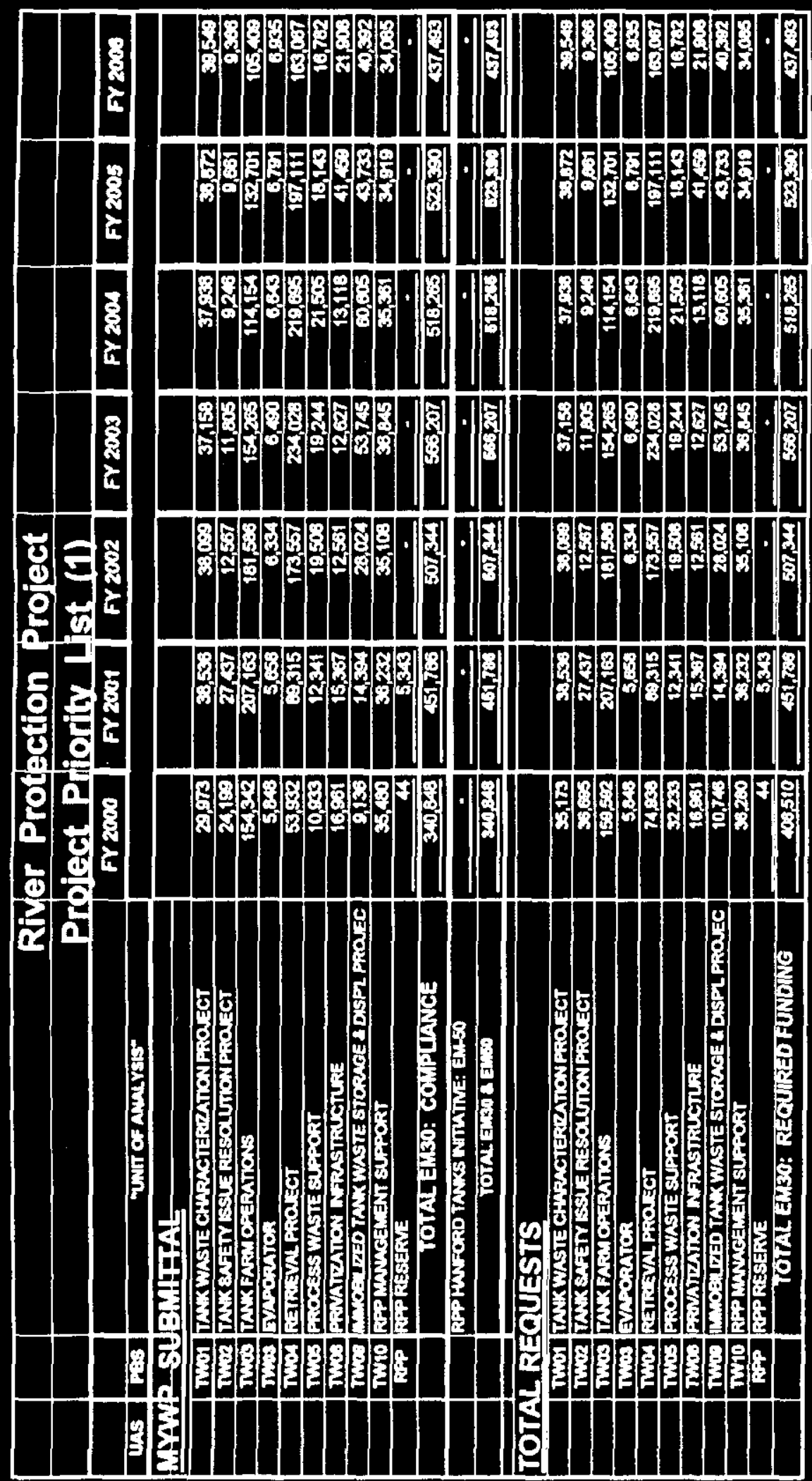


RPP-5044

B-8

This page intentionally left blank. 
Appendix C INSTRUCTIONS ON ACCESSING ELECTRONIC MYWP 
RPP-5044

C-2

This page intentionally left blank. 


\section{INSTRUCTIONS ON ACCESSING ELECTRONIC MYWP}

1. Click on your Windows "Start" button.

2. Select "Programs".

3. Select "(HLAN)".

4. Select "Software Distribution".

5. Once in Software Distribution go to the "Hanford Site Applications" menu, Click the "OK" button .

6. Select "Hanford Data Integrator-HANDI v4.1", Click on the Install button.

7. After following the Install instructions, Click on your Windows "Start" button.

8. Select "Programs".

9. Select HANDI 4.x, (" $x$ " indicates version and may change due to updates, this does not mean you need to reinstall, these updates will occur automatically at the time you access HANDI, unless otherwise directed from SP\&l).

10. Select MYWP from the HANDI Menu.

11. Select what version of the MYWP you want to access (currently only Planning is available).

12. Once in the MYWP, select if you want to view the Table of Contents (TOC) for the complete MYWP or by a subset of the complete document (i.e.. Baseline data, or Specs/Requirements).

13. Select either a Mission or PBS level from the WBS tree, then select what products you want to view from the TOC list.

NOTE: Access is limited to computers connected to the HLAN. 
RPP-5044

C-4

This page intentionally left blank. 
Appendix D
ELECTRONIC ACCESS OF TBR DATA 
RPP-5044

D-2

This page intentionally left blank. 


\section{APPENDIX D ELECTRONIC ACCESS OF TBR DATA}

\section{Purpose}

The purpose of the Access Database is to provide an electronic, configuration-controlled, central-file repository for Technical Basis Review (TBR) packages using a predefined directory structure and naming convention.

\section{System Description}

The electronic repository for the River Protection Project (RPP) TBRs is located on fileserver AP005, share name TWRSTbrData. Each TBR package consists of the following four files.

- Cost Est. Input Sheets

Fragnets

- Resource Report

- Narrative

\section{CEIS999999.XLS}

FRAG999999.pdf

Resr999999.out (.pdf at a later date)

TBR999999.doc

A TBR package can be in the following three states at any given time, reflected by the following root directory structure.

BaselineXX. This is the state of the baseline at the time of approval.

Baseline+Changes. This is the BaselineXX with approved changes providing the current state of the baseline at any given time.

ChangeInProg. Files in this directory are undergoing some type of change action.

Microsoft SourceSafe is the management tool used to maintain configuration control of the files located in Baseline+Changes. SourceSafe both provides the history of all changes and assigns the revision numbers. SourceSafe is controlled by at least one administrator from each project baseline summary (PBS). The administrators have permission to manage only their own PBSs within SourceSafe. To date, all designated PBS administrators have been trained in the use of SourceSafe. 
RPP-5044

D-4

\section{Access Instructions}

The following steps provide access to the TWRSTbrData repository.

1. Log on to Hanford Local Area Network (HLAN).

2. Open either "My Computer" or "Windows Explorer."

3. Map a drive to IIAP005ITWRSTbrData, unless the drive has been previously mapped.

4. Open the drive just mapped and drill down to one of the following directories.
- Baseline99
- Baseline+Changes
ChangeInProg.

5. The 10 PBSs are listed in each directory.

6. The supporting TBRs are located under each PBS, one folder for each TBR. The exception is in the directory "CangeInProg." Under this directory, each folder lists the name of the person responsible for a particular change in progress.

7. Each TBR folder contains the four files that make up a TBR; the CEIS, the Narrative, the Resource Report, and the Logic Diagram. For example:

- Cost Est. Input Sheets

Fragnets

Resource Report

- Narrative
CEIS999999.XLS

FRAG999999.pdf

Resr999999.out (.pdf at a later date)

TBR999999.doc. 
RPP-5044

Distr-1

\section{DISTRIBUTION}

U.S. Department of Energy,

Office of River Protection

J. C. Peschong (18) H6-60

Fluor Daniel Hanford, Inc.

J. W. Bosley (8) G1-24

Lockheed Martin Hanford Corporation

$\begin{array}{ll}\text { D. L. Lenseigne (20) } & \text { S7-80 }\end{array}$

Lockheed Martin Services, Inc.

Central Files

B1-07

Document Processing Center

H6-08

Pacific Northwest National Laboratory

T. L. Traub

H2-53

Hanford Technical Library

P8-55 
RPP-5044

Distr-2

This page intentionally left blank. 